UNIVERSIDADE DE SÃO PAULO

INSTITUTO DE GEOCIÊNCIAS

PETROGRAFIA E QUÍMICA MINERAL DE XENÓLITOS

MANTÉLICOS DA INTRUSÃO KIMBERLÍTICA INDAIÁ, MONTE

CARMELO, MG.

\title{
FELIX NANNINI
}

Orientador: Prof. Dr. Valdecir de Assis Janasi

\section{DISSERTAÇÃO DE MESTRADO}

Programa de Pós-Graduação em Mineralogia e Petrologia

SÃO PAULO

2011

\section{FELIX NANNINI}




\title{
PETROGRAFIA E QUÍMICA MINERAL DE XENÓLITOS MANTÉLICOS DA INTRUSÃO KIMBERLÍTICA INDAIÁ, MONTE CARMELO, MG.
}

\author{
Dissertação apresentada ao \\ Instituto de Geociências da \\ Universidade de São Paulo para \\ obtenção do título de Mestre em \\ Geologia (versão corrigida). A \\ versão original se encontra na \\ Biblioteca do IGc/USP.
} Área de Concentração: Mineralogia
e Petrologia

Orientador: Prof. Dr. Valdecir de Assis Janasi

SÃO PAULO

2011 
Autorizo a reprodução e divulgação total ou parcial deste trabalho por qualquer meio convencional ou eletrônico para fins de estudo e pesquisa, desde que citada a fonte.

Ficha catalográfica preparada pelo Serviço de Biblioteca e Documentação do Instituto de Geociências da Universidade de São Paulo

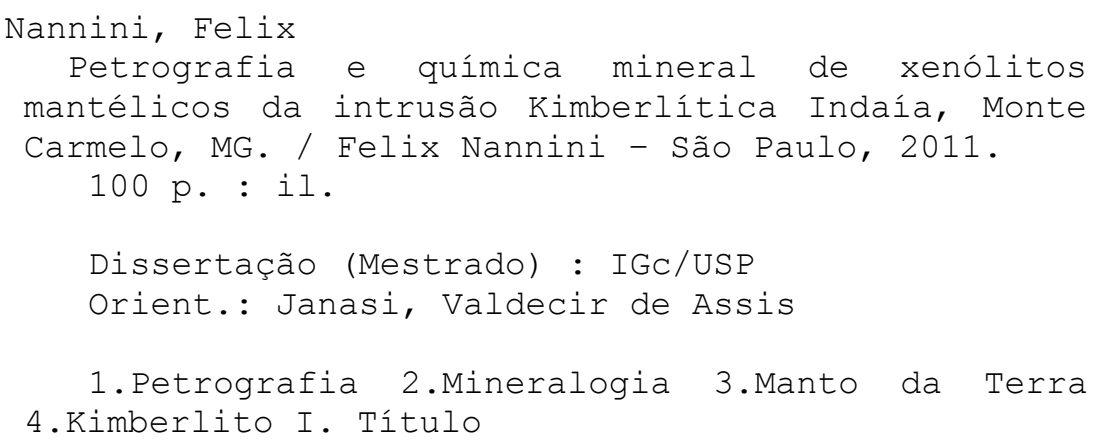





\section{RESUMO}

O Kimberlito Indaiá, situado $25 \mathrm{~km}$ a norte da cidade de Monte Carmelo, na região oeste de Minas Gerais, é intrusivo em granitóides cataclasados associados ao Grupo Araxá, na Faixa de Dobramentos Brasília. O corpo apresenta forma subcircular e diâmetro principal de 220 m na direção NE-SW; em sua porção NE ocorre uma intrusão de kamafugito associada de $120 \mathrm{~m}$ de diâmetro. A rocha exibe coloração cinza escura e textura inequigranular bem destacada, sendo constituída por uma matriz afanítica na qual estão dispersos macrocristais de olivina (abundantes), ilmenita, flogopita e piroxênio, além de xenólitos mantélicos e crustais de dimensões variadas.

Os xenólitos mantélicos são constituídos, em ordem de abundância, por harzburgitos $(41 \%)$, lherzolitos $(37 \%)$, dunitos (14\%), mica piroxenitos $(6 \%)$ e xenólito polimítico (2\%). Os harzburgitos, lherzolitos e dunitos exibem, além das fases primárias (olivina, enstatita e diopsídio), teores subordinados de espinélio, cromita, diopsídio, flogopita, ilmenita e raro anfibólio. A textura predominante é grossa (protogranular), ocorrendo subordinadamente as texturas granoblástica e porfiroclástica. Análises químicas por microssonda eletrônica revelaram que as fases silicáticas possuem valores $\mathrm{Mg} /(\mathrm{Mg}+\mathrm{Fe})$ maiores em harzburgitos e dunitos e menores nos lherzolitos. Os mica piroxenitos (flogopita+enstatita+ilmenita) e os xenólitos polimíticos (olivina+diopsídio+ilmenita+flogopita) apresentam mineralogia mais complexa, possuindo em adição magnetita, perovskita, barita, zircão, badeleíta, pentlandita, galena e uma fase mineral rara ainda não identificada. As razões $\mathrm{Mg} /(\mathrm{Mg}+\mathrm{Fe})$ das fases silicáticas são mais baixas que as dos xenólitos de peridotitos. As características químicas da flogopita e da ilmenita destes xenólitos indicam similaridades com os xenólitos da suíte MARID.

A variedade textural dos xenólitos estudados, de grossa (protogranular) a granoblástica, é uma evidência de processos de recristalização por deformação mecânica. A aplicação de geotermômetros da literatura para os espinélio lherzolitos forneceu temperaturas de equilíbrio entre 655 a $908^{\circ} \mathrm{C}$, em concordância com dados de outras intrusões do oeste mineiro. A presença de flogopita e ilmenita sob a forma de bolsões nos xenólitos de peridotitos, bem como nos mica piroxenitos e xenólitos polimíticos, são indicativos da atuação de processos de metassomatismo no manto da região de Monte Carmelo. 


\section{ABSTRACT}

The Indaiá Kimberlite, located $25 \mathrm{~km}$ North of Monte Carmelo in the western Minas Gerais State, is intrusive in cataclased granitoids related to the Araxá Group, part of the Brasilia Fold Belt. The body has a subcircular 220-meter head-diameter shape (NE-SW); an associated 120-meter diameter intrusion of kamafugite occurs in its NE portion. The rock is dark gray and displays prominent inequigranular texture, consisting of an aphanitic matrix in which macrocrystals of olivine (abundant), ilmenite, pyroxene and phlogopite, as well as mantle and crustal xenoliths of different sizes are dispersed.

These mantle xenoliths are composed, in order of abundance, by harzburgites (41\%), lherzolite $(37 \%)$, dunite (14\%), mica pyroxenite $(6 \%)$ and polymictic xenolith $(2 \%)$. Harzburgites, lherzolites and dunites exhibit, besides the main minerals (olivine, enstatite and diopside), small amounts of spinel, chromite, diopside, phlogopite, ilmenite and rare amphibole. The predominant texture is coarse (protogranular); subordinately, granoblastic and porfiroclastic textures are observed. Chemical analysis by electron microprobe showed that the silicate phases have higher values of $\mathrm{Mg} /(\mathrm{Mg}+\mathrm{Fe})$ in harzburgites and dunites as compared to lherzolites. Mica pyroxenite (enstatite + phlogopite + ilmenite) and polymictic xenoliths (olivine + diopside + phlogopite + ilmenite) have more complex mineralogical features than the other xenoliths, showing in addition magnetite, perovskite, barite, zircon, baddeleyite, pentlandite, galena and a rare phase not yet identified. $\mathrm{The} \mathrm{Mg} /(\mathrm{Mg}+\mathrm{Fe})$ ratio in silicate phases are lower than in the peridotite xenoliths. The chemical characteristics of phlogopite and ilmenite of these xenoliths indicate similarities with the MARID suite xenoliths.

The textural variety of the studied xenoliths, from coarse (protogranular) to granoblastic, is an evidence of crystallization processes by mechanical deformation. The application of geothermometers described in the literature to spinel lherzolites yielded equilibrium temperatures between 655 and $908^{\circ} \mathrm{C}$, agreeing with data from other intrusions from western Minas Gerais. The presence of ilmenite and phlogopite in the form of pockets in peridotite xenoliths, as well as in mica pyroxenite and polymictic xenoliths, is indicative of mantle metasomatic processes in the Monte Carmelo region. 


\section{ÍNDICE}

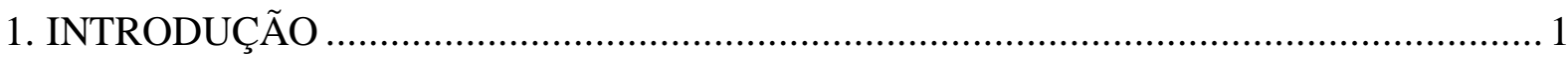

1.1. Histórico do estudo sobre xenólitos do manto ........................................................ 1

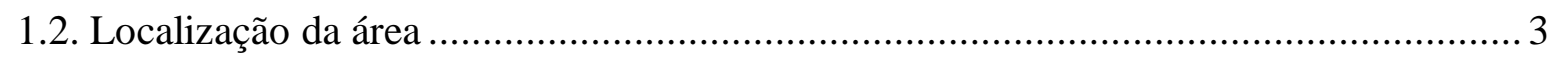

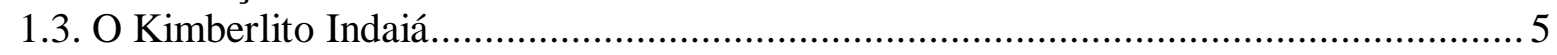

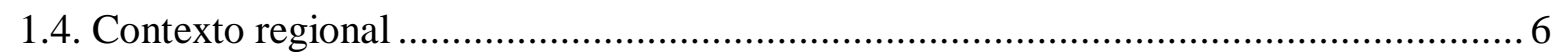

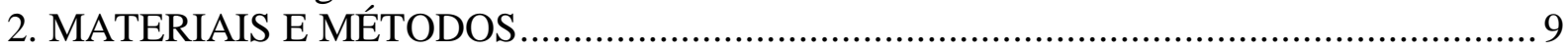

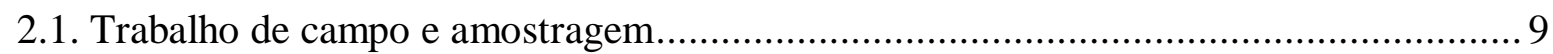

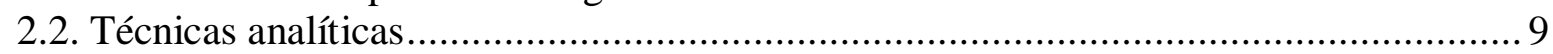

2.2.1. Microscopia óptica .....................................................................................

2.2.2. Microscópio eletrônico de varredura (MEV) ………………………………..... 10

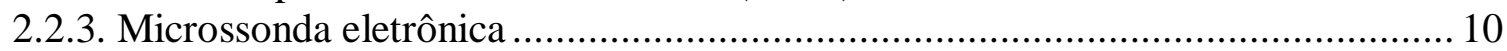

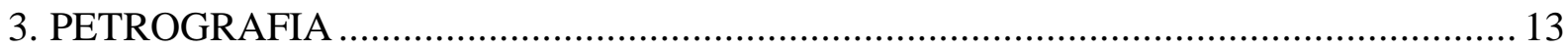

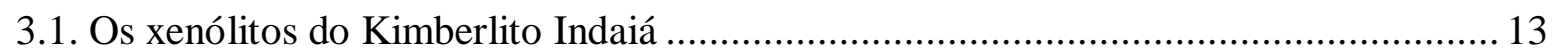

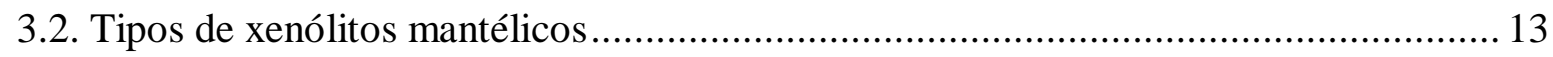

3.3. Classificação mineralógica dos xenólitos mantélicos ................................................. 14

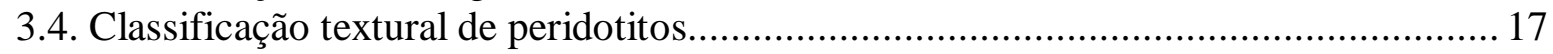

3.4.1. Textura grossa (coarse) .............................................................................. 17

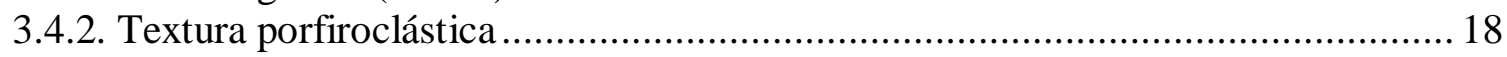

3.4.3. Textura granoblástica................................................................................... 19

3.5. Classificação petrográfica dos xenólitos do Kimberlito Indaiá ……………………..... 21

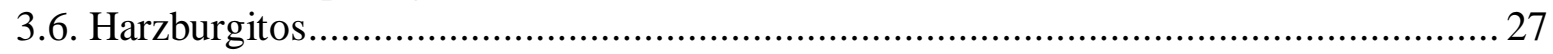

3.6.1. Harzburgito com espinélio e textura grossa tabular .......................................... 27

3.6.2. Harzburgito com cromita e textura granoblástica ……………............................ 29

3.6.3. Harzburgito de textura grossa, com cristais pequenos de olivina recristalizada na

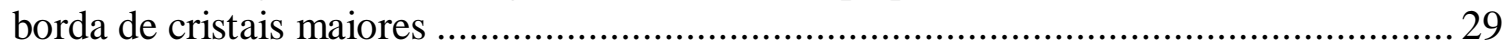

3.6.4. Harzburgito de textura grossa e bolsões de flogopita........................................... 32

3.6.5. Harzburgito de textura grossa, com bolsões de clinopiroxênio .............................. 33

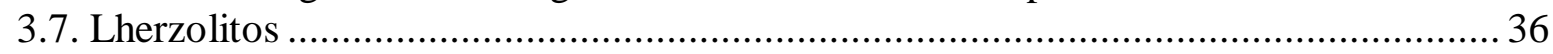

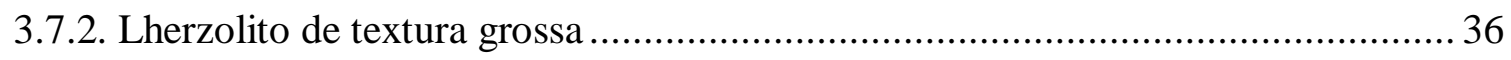

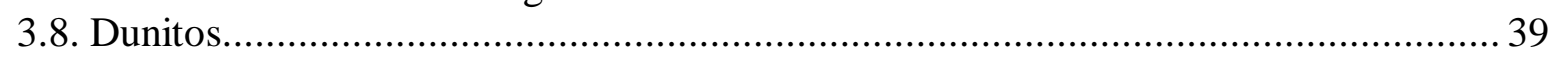

3.8.1. Flogopita dunito de textura grossa ………………………............................... 39

3.8.2. Dunito com cromita e textura granoblástica ………………………………...... 42

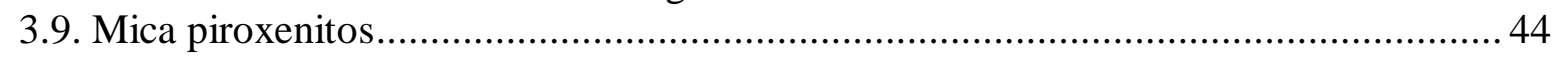

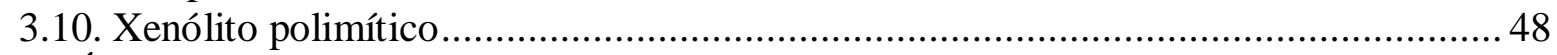

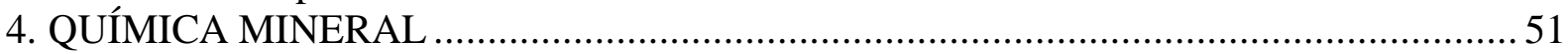

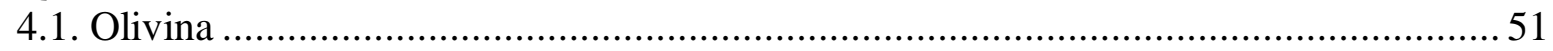

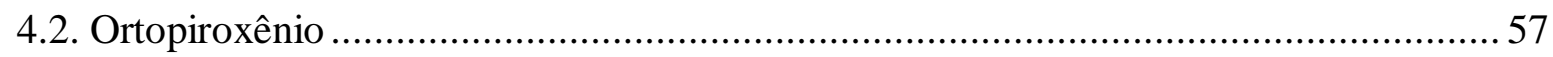

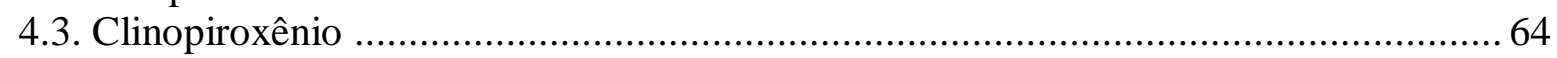

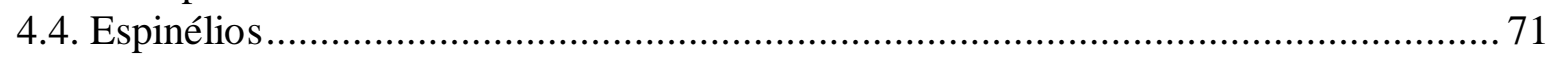

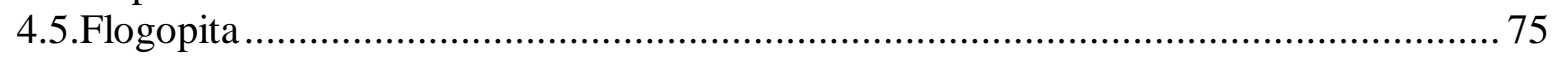

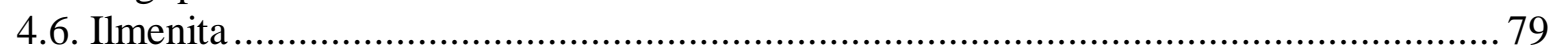

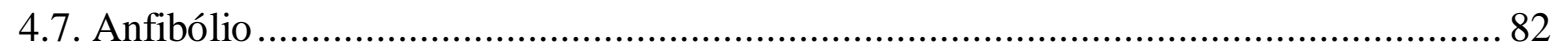

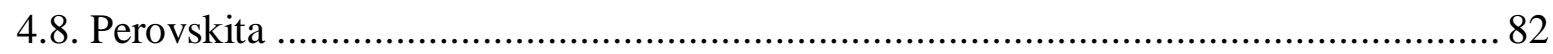

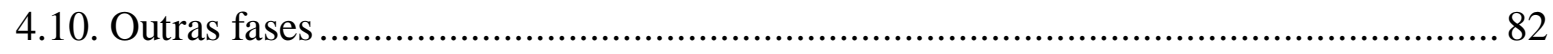

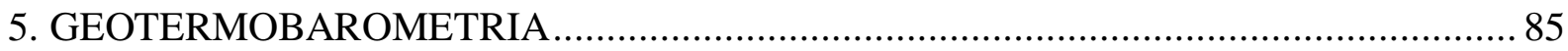

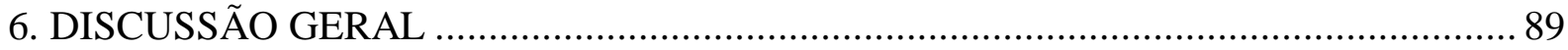




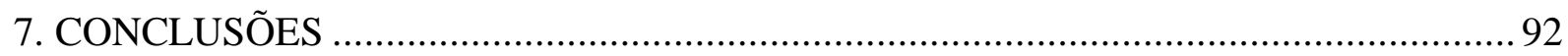

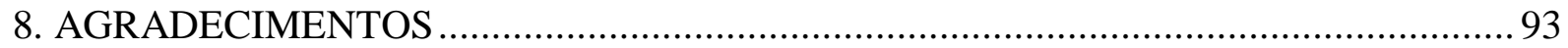

9. REFERÊNCIAS BIBLIOGRÁFICAS .................................................................. 94

\section{ÍNDICE DE FIGURAS}

Figura 1- Localização geográfica do Kimberlito Indaiá, situado a norte da cidade de Monte Carmelo, na região oeste de Minas Gerais

Figura 2 - Afloramento original do Kimberlito Indaiá em foto tomada em julho de 1975 pelo

Prof. Darcy P. Svisero.

Figura 3 - Contraste entre os solos castanho avermelhado do Kimberlito Indaiá e o solo branco da encaixante granítica, conforme delineado na foto.

Figura 4- Contexto geológico do Kimberlito Indaiá. A) Posicionamento do corpo em relação ao Cráton São Francisco; B) Posicionamento do Kimberlito Indaiá em relação às rochas encaixantes; e C) Forma do corpo em superfície, com local de afloramento e posição em relação à estrada de terra e o vale perene adjacente.

Figura 5 - A) Classificação de rochas ultramáficas segundo Streckeisen (1976). B)

Classificação mineralógica dos xenólitos do Kimberlito Indaiá estudados neste trabalho.

Destaca-se a tendência harzburgítica dos xenólitos.

Figura 6- Exemplos representativos dos diversos tipos de xenólitos em amostras em meio à

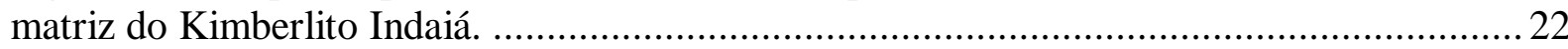

Figura 7- Exemplos de xenólitos representativos do Kimberlito Indaiá. .............................. 23

Figura 8- Seção In1/9 representando harzburgito contendo espinélio castanho avermelhado e

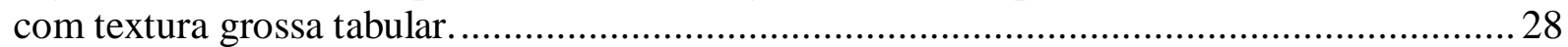

Figura 9- Seção In1/3 de harzburgito com cromita e textura granoblástica.......................... 30

Figura 10- Seção In1/1 representando harzburgito de granulação grossa, com macrocristais de

olivina recristalizados nas bordas dos cristais maiores...................................................... 31

Figura 11- Seção In1/20b representando harzburgito de textura grossa e bolsões de flogopita

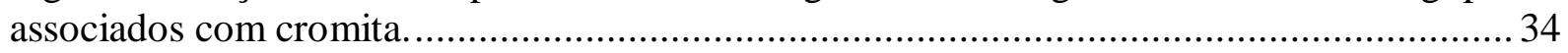

Figura 12- Seção In1/12 representando harzburgito de textura grossa, com veios e bolsões de

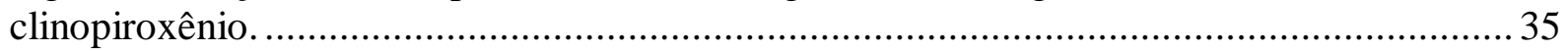

Figura 13- Seção In1/4 representando lherzolito com espinélio castanho avermelhado e

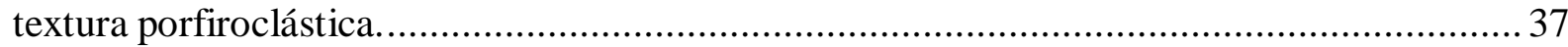

Figura 14- Seção In1/14a representando lherzolito com espinélio castanho avermelhado

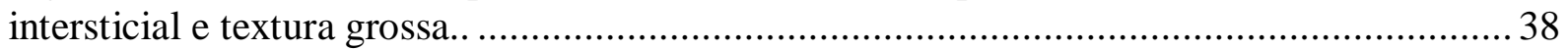

Figura 15- Seção In1/2 representando flogopita dunito de textura grossa............................ 40

Figura 16- Imagens de microscópio eletrônico de varredura mostrando as texturas entre os diferentes minerais opacos encontrados em meio aos bolsões de flogopita da seção In1/2 ...41

Figura 17- Seção In1/24a representando dunito com cromita e textura granoblástica. ...........43

Figura 18- Seção In1/24b representando mica piroxenito................................................ 45

Figura 19- Seção In1/31 representando mica piroxenito. .............................................. 46

Figura 20- Imagem de microscópio eletrônico de varredura mostrando em detalhe os minerais

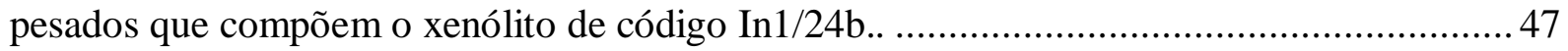

Figura 21- Seção In1/6 representando xenólito polimítico. ............................................... 49

Figura 22- Imagem de microscópio eletrônico de varredura mostrando em detalhe os minerais

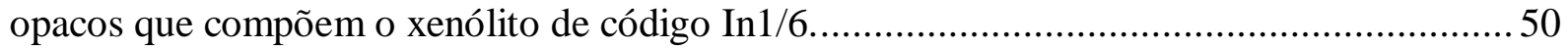


Figura 23- Composição de olivinas de xenólitos do Kimberlito Indaiá mostrando os campos de peridotitos mantélicos e piroxenitos cumuláticos, com dados de referência extraídos de Zhang et al., 2010.

Figura 24- Composição química de ortopiroxênio de xenólitos do Kimberlito Indaiá. ........... 63

Figura 25- Composição química de clinopiroxênio de xenólitos do Kimberlito Indaiá.......... 69

Figura 26- A)Diagrama $\mathrm{Na}_{2} \mathrm{O}$ versus \#Mg de clinopiroxênio de xenólitos do Kimberlito

Indaiá. B) Diagrama $\mathrm{Al}_{2} \mathrm{O}_{3}$ versus \#Mg de clinopiroxênio dos xenólitos estudados (Zhang et

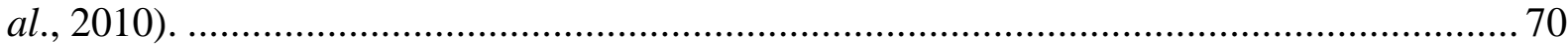

Figura 27- Variação composicional de espinélios de xenólitos do Kimberlito Indaiá. ........... 74

Figura 28- Diagrama composicional de micas adaptado de Mitchell (1995)......................... 78

Figura 29- Composição química das flogopitas dos xenólitos estudados em diagrama de $\mathrm{Al}_{2} \mathrm{O}_{3}$ vs. $\mathrm{Mg} /(\mathrm{Mg}+\mathrm{Fe})$ mostrando os campos de xenólitos MARID e PIC, modificado de Grégoire

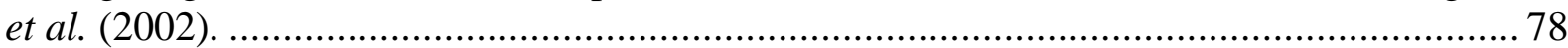

Figura 30- Variação química da ilmenita de xenólitos do Kimberlito Indaiá, em diagrama de

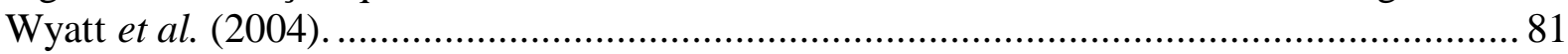

Figura 31- Variação química da ilmenita de xenólitos do Kimberlito Indaiá em diagrama de $\mathrm{MgO}$ vs. $\mathrm{TiO}_{2}$ mostrando os campos de xenólitos MARID e PIC, modificado de Grégoire et al.(2002).

Figura 32 - Dados de pressão e temperatura de granada lherzolitos da região de Coromandel

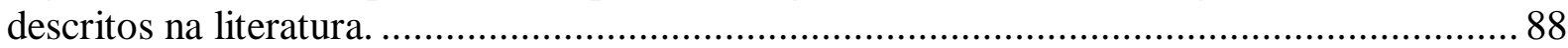

Figura 33 - Diagrama de campo de estabilidade Temperatura vs. Pressão das fases aluminosas plagioclásio, espinélio e granada, extraído de Pearson et al. (2003), mostrando a temperatura e pressão de equilíbrio de dois xenólitos do Kimberlito Indaiá.

\section{ÍNDICE DE TABELAS}

Tabela 1- Padrões químicos utilizados para todos os minerais analisados. 12 Tabela 2- Nomenclatura utilizada para a classificação textural de xenólitos peridotíticos segundo vários autores. As cores utilizadas nesta tabela indicam semelhanças descritivas entre as texturas identificadas e nomeadas pelos diferentes autores. ........................................ 20 Tabela 3- Classificação de Harte (1977) para peridotitos mantélicos, segundo a textura. ...... 20 Tabela 4- Classificação tipológica dos enclaves estudados do Kimberlito Indaiá. ................ 24 Tabela 5 - Análises químicas de olivina de xenólitos da intrusão Indaiá 1, obtidas por meio da

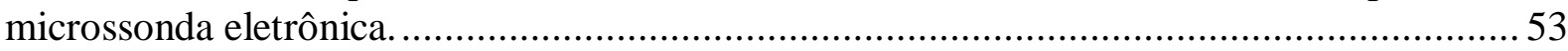
Tabela 6- Análises químicas de ortopiroxênio de xenólitos da intrusão Indaiá 1, obtidas por

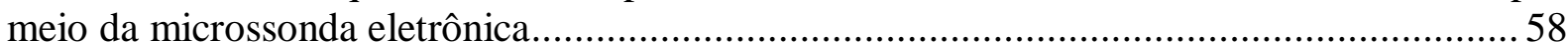
Tabela 7- Análises químicas de clinopiroxênio de xenólitos da intrusão Indaiá 1, obtidas por

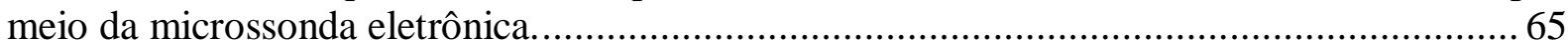

Tabela 8- Análises químicas de minerais do grupo dos espinélios, de xenólitos da intrusão Indaiá 1 , obtidas por meio da microssonda eletrônica.................................................. 72 Tabela 9- Análises químicas de flogopita de xenólitos da intrusão Indaiá 1, obtidas por meio

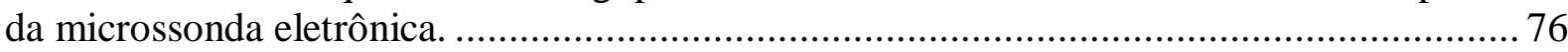
Tabela 10- Análises químicas de ilmenita de xenólitos da intrusão Indaiá 1, obtidas por meio

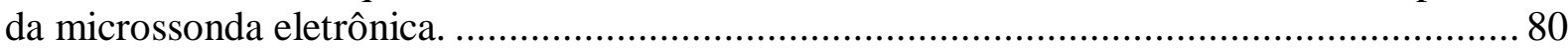
Tabela 11- Análises químicas de anfibólio em xenólitos da intrusão Indaiá 1, obtidas por meio da microssonda eletrônica.

Tabela 12- Análises químicas de outras fases minerais não identificadas em xenólitos da intrusão Indaiá 1, obtidas por meio da microssonda eletrônica. 
Tabela 13- Análises semi-quantitativas obtidas por EDS de pentlandita, galena e barita.......84 Tabela 14- Dados de temperatura e pressão obtidos pelos termômetros Wells (1977) e Brey \& Khöler (1990), e barômetro de MacGregor (1974), de harzburgitos e lherzolitos do Kimberlito Indaiá, e comparação com dados geotermobarométricos de outros corpos próximos à

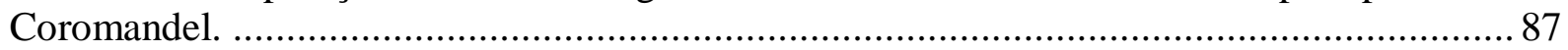
Tabela 15- Comparação de xenólitos de dois corpos da Província Kimberlítica de Coromandel (Indaiá e Limeira) e de corpos da África do Sul e Tanzânia...... 91 


\section{INTRODUÇÃO}

Xenólitos (do grego xenos = estranho + lito $=$ pedra) são fragmentos de rochas incorporados por magmas. Desempenham um papel importante nos processos geológicos gerais, fornecendo informações sobre processos dinâmicos operantes na litosfera. O estudo destes materiais desenvolveu-se nas últimas décadas, acompanhando de perto a evolução que houve no desenvolvimento das técnicas de análises químicas.

Distinguem-se, fundamentalmente dois grupos de xenólitos: crustais e mantélicos. Os primeiros são representados por rochas crustais entre as quais se destacam granitóides, basaltos, anfibolitos, gnaisses, xistos, entre outras. O segundo grupo reúne rochas ultramáficas, sendo representadas principalmente por peridotitos e eclogitos.

O estudo dos xenólitos mantélicos sofreu um impulso extraordinário a partir do estabelecimento das Conferências Internacionais de Kimberlitos, iniciadas com a primeira reunião ocorrida em Cape Town em 1973. Entre as linhas de pesquisa apresentadas nesta reunião, foram propostos estudos de kimberlitos, de diamante e xenólitos mantélicos, com o objetivo de investigar as características mineralógicas e petrológicas do manto. Como resultado surgiu nos anos subsequentes uma literatura ampla sobre xenólitos mantélicos, onde se destacam os trabalhos básicos de referência de Nixon $(1973,1987)$ e Dawson (1980) além de inúmeros textos publicados nos Proceedings das conferências seguintes, bem como nos periódicos especializados.

\subsection{Histórico do estudo sobre xenólitos do manto}

As primeiras informações sobre xenólitos do manto foram apresentadas por Wagner (1914) e Williams (1932) os quais descreveram nódulos de peridotitos de vários kimberlitos da África do Sul. Nixon et al. (1963) iniciou um trabalho sistemático de xenólitos da região de Lesotho e posteriormente editou uma monografia reunindo dados geológicos diversificados sobre estes materiais (Nixon 1973). Neste volume são reunidas pela primeira vez centenas de análises químicas sobre xenólitos de peridotitos, piroxenitos, eclogitos, bem como xenocristais de granada, espinélio, olivina, orto e clinopiroxênio e zircão, os quais foram denominados por ele de nódulos discretos. Merecem destaque os textos de Nixon \& Boyd (1973a) no qual são reconhecidas as texturas granular e cisalhada; o de Nixon \& Boyd (1973b) onde são apresentados os dados de temperatura, pressão e profundidade dos 
xenólitos; e o de Nixon et al.(1973) onde os autores propõem um modelo do manto na região de Lesotho que serviria de base para todos os demais trabalhos subseqüentes.

Nos anos seguintes surgiram dois novos livros que consolidaram esta linha de pesquisa. Dawson (1980) apresentou uma classificação petrológica dos xenólitos que continua sendo aceita até os dias de hoje, e Nixon (1987) editou um novo livro (Mantle Xenoliths) no qual são reunidos dados mineralógicos e petrológicos de xenólitos de todas as regiões cratônicas do planeta. Este livro reúne contribuições de 78 autores de diversos países do mundo e continua sendo a obra de referência para o estudo de xenólitos mantélicos.

Finalmente merece destaque a revisão de Pearson et al. (2003) onde são discutidos e comparados dados referentes a xenólitos de áreas continentais e oceânicas e também de inclusões minerais presentes em diamantes.

No Brasil são conhecidas ocorrências de xenólitos mantélicos em diversos estados do território. Almeida $(1958,1961)$ descreveu xenólitos ultrabásicos em basaltos de Fernando de Noronha e Trindade, respectivamente. Leonardos \& Araújo (1968) e Sial (1977) descreveram xenólitos de peridotitos em basaltos alcalinos dos estados da Paraíba e Rio Grande do Norte. Helmbold (1968) apresentou um estudo detalhado de lherzolitos de basaltos do estado do Rio de Janeiro.

Xenólitos de peridotitos em kimberlitos foram descritos por Svisero et al. (1977), no kimberlito Redondão, localizado na região SW do Piauí. Posteriormente, Meyer \& Svisero (1987) apresentaram um levantamento geográfico de todas as ocorrências conhecidas na época no continente sul-americano.

Nos últimos anos foram desenvolvidos estudos detalhados de xenólitos em kimberlitos por diversos autores. Leonardos et al .(1995) descreveram granada lherzolitos do Kimberlito Alagoinha (Três Ranchos 4), MG, apresentando também dados de pressão e temperatura de equilíbrio. Costa (2008) apresentou sua dissertação de mestrado no qual são discutidos dados de geotermobarometria de diversos tipos de xenólitos do Kimberlito Canastra, Vargem Bonita, MG. Thomaz (2009) descreveu xenólitos de peridotitos no Kimberlito Régis, localizado em Carmo do Paranaíba, MG. Almeida (2009) descreveu xenólitos de peridotitos no Kimberlito Limeira, Monte Carmelo, MG, e xenólitos de peridotitos em basaltos da região de Ubatuba, SP. Costa (2010) descreveu diversos tipos de xenólitos, incluindo peridotitos, piroxenitos e eclogitos da região de Juína, MT. 
Dando continuidade a esta linha de pesquisa, nesta dissertação são descritos os xenólitos presentes no Kimberlito Indaiá, localizado nas proximidades do corpo Limeira, ambos situados a meio caminho entre as cidades de Coromandel e Monte Carmelo, na região oeste de Minas Gerais.

Este trabalho abordará de forma detalhada as características mineralógicas e petrográficas bem como as características químicas em termos de elementos maiores, dos minerais constituintes dos xenólitos da Intrusão Indaiá. O estudo dos xenólitos deste kimberlito, bem como o de outros da região, serão aprofundados futuramente em uma tese de doutoramento. Neste caso, serão realizadas análises detalhadas de elementos traços por LAICPMS, de fundamental importância para o entendimento da composição química e evolução do manto (Janasi et al. 2010, Eggins et al. 1998).

\subsection{Localização da área}

O Kimberlito Indaiá está localizado cerca de $25 \mathrm{~km}$ a norte da cidade de Monte Carmelo, conforme mostra a Figura 1. O local pode ser alcançado facilmente a partir de Monte Carmelo, uma das cidades prósperas da região, possuindo uma boa malha de estradas asfaltadas que facilitam o trânsito na área. Partindo-se de Monte Carmelo, após o percurso de $20 \mathrm{~km}$ pela estrada que dá acesso a Abadia dos Dourados, toma-se à esquerda uma estrada de fazenda a qual, após um percurso de $4 \mathrm{~km}$, conduz ao local da intrusão.

O corpo pode ser alcançado também partindo-se da cidade de Coromandel, que é a localidade de referência do comércio de diamante na região. Partindo deste local, toma-se a estrada asfaltada que conduz a Abadia dos Dourados, e de lá segue-se por um percurso de 10 km em direção a Monte Carmelo. Após o trevo que leva a Douradoquara, toma-se a primeira estrada de fazenda à direita, a qual dá acesso à intrusão após 4 km. 


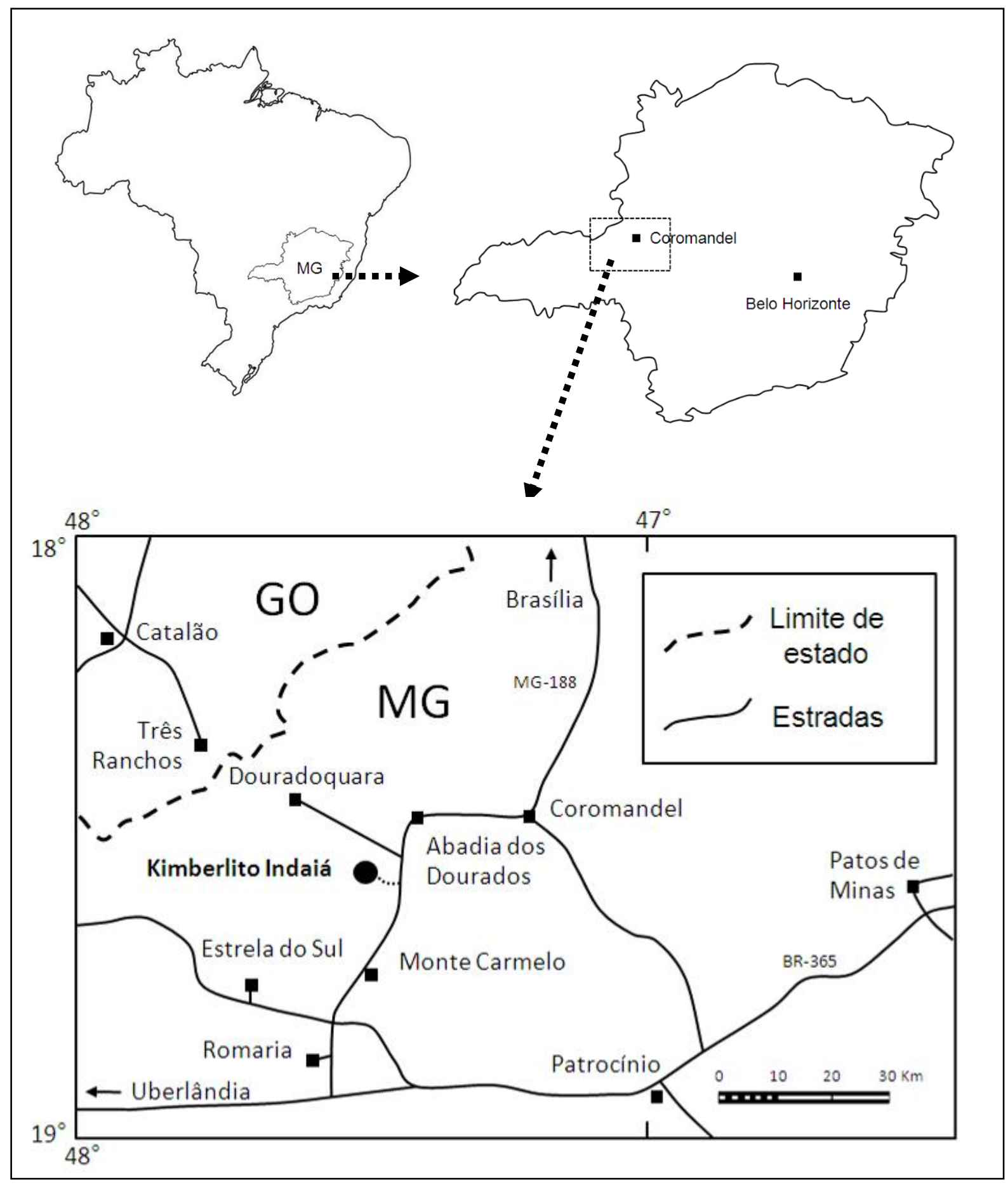

Figura 1- Localização geográfica do Kimberlito Indaiá, situado a norte da cidade de Monte Carmelo, na região oeste de Minas Gerais. 


\subsection{O Kimberlito Indaiá}

O Kimberlito Indaiá foi descoberto no mês de julho de 1975 em uma campanha de campo feita pelo Prof. Darcy Pedro Svisero e o geólogo Vitor M. N. Feitosa na região do município de Monte Carmelo, MG. A Figura 2 mostra a foto tomada do afloramento, que na época media em torno de $2 \mathrm{~m}^{2}$. A ação do intemperismo ampliou acentuadamente a área de exposição da intrusão, que nos dias de hoje se entende por cerca de quase cinquenta metros de extensão.

O corpo aflora ao longo de um vale perene localizado na porção sul, ao longo do contato do kimberlito com a encaixante granítica regional, na forma de rocha fresca, com pouca ou nenhuma alteração. O contraste de cor entre os dois tipos de solo foi um dos fatores determinantes para a localização da intrusão na época. Os granitos da região de Monte Carmelo desenvolvem solos de pouca espessura de coloração em geral cinza clara, que contrastam com a coloração castanha avermelhada observada tanto na intrusão Indaiá como nos demais corpos kimberlíticos da região. Outro fator indicador foi a presença de vegetação densa na área da intrusão, contrastando com a vegetação rala e retorcida do cerrado (Figura 3).

A rocha do corpo Indaiá tem coloração cinza escura e textura inequigranular resultante da presença de macrocristais subédricos de olivina (abundantes), além de ilmenita e flogopita (pouco frequentes), dispersos em uma matriz afanítica escura constituída por olivina, flogopita, monticellita, perovskita, espinélio, calcita e serpentina. Além destes componentes, a rocha contém ainda macrocristais, megacristais, nódulos carbonáticos, autólitos, xenólitos mantélicos e crustais, com formas e dimensões variadas (Meyer \& Svisero 1991, Svisero \& Ulbrich 1997 e Silva 2008). Segundo Silva (2008) a assembléia mineralógica do Kimberlito Indaiá e a presença de ilmenitas magnesianas poderiam sugerir condições de formação de diamantes, porém a ausência de macrocristais de espinélio com alto $\mathrm{Cr}$ e a ausência de granadas frustram esta expectativa.

O corpo é intrusivo em granitóides cataclasados do Grupo Araxá, pertencentes à Faixa de Dobramentos Brasília, importante unidade tectônica situada entre a borda NE da bacia do Paraná e a margem SW do Cráton São Francisco, conforme esquematizado na Figura 4. O Grupo Araxá foi definido por Barbosa et al. (1970), e em sua área ocorrem exposições amplas de granitóides, extensas intercalações de mica xistos, nos quais são frequentes lentes de anfibolitos com espessuras de até $20 \mathrm{~m}$, concordando com a xistosidade predominante NW- 
SE. Estudos de Seer et al. (2000) revelaram que esses anfibolitos possuem características químicas semelhantes às de basaltos constituintes de dorsais meso-oceânicas (MORB). Xistos e granito intercalam-se em toda a região situada entre Monte Carmelo e Abadia dos Dourados. Diferenciam-se pelo solo de alteração sendo branco a cinza claro nos granitóides e rosa claro nas áreas de mica xistos.

O mapeamento geológico detalhado com o uso de magnetometria terrestre e gamaespectrometria indicou que o kimberlito possui formato piriforme e diâmetro principal de 220 m na direção N-S (Svisero \& Haralyi 1984). Da mesma forma que a intrusão Limeira, o corpo Indaiá possui também uma intrusão satélite de natureza kamafugítica, de formato elipsoidal e diâmetro principal de $120 \mathrm{~m}$, localizada na porção NE do kimberlito. Tanto o corpo Indaiá como sua intrusão satélite possuem xenólitos mantélicos, sobretudo no kimberlito, além de enclaves crustais de natureza granítica.

\subsection{Contexto regional}

O termo Província Ígnea do Alto Paranaíba (PIAP) foi proposto por Gibson et al. (1995) designando as rochas alcalinas de idade cretácea (80-90 Ma) que ocorrem no sudeste de Minas Gerais e sudoeste de Goiás, seguindo um lineamento NW-SE ao longo da borda NE da Bacia do Paraná. As rochas da PIAP ocorrem na forma de diatremas, chaminés, lavas kamafugíticas e intrusões carbonatíticas, e constituem uma das maiores ocorrências em volume de rochas máficas potássicas no mundo. Estas ocorrências são intrusivas na Faixa de Dobramentos Brasília, localizada a oeste do Cráton São Francisco (Araújo et al. 2001). Os limites do Cráton São Francisco em relação à Faixa Brasília ainda não são bem definidos, pois esta constitui nappes com vergência para ao cráton. Estudos de gravimetria e estimativas obtidas em xenólitos indicam que a PIAP se localiza no limite leste, em subsuperfície, do Cráton São Francisco (Gibson et al. 1995).

A intrusão Indaiá, pertencente à PIAP diversas intrusões de natureza kimberlítica, juntamente com outros corpos já conhecidos da região, tais como Limeira, Japecanga, Vargem, Santa Clara, Poço Verde, Grotão, Cedro, Santa Rosa, que entre outros, fazem parte do Campo Kimberlítico de Coromandel, e juntamente com os campos de Três Ranchos, Carmo do Paranaíba e Bambuí, constituem a Província Kimberlítica do Alto Paranaíba (Svisero et al. 2010). 


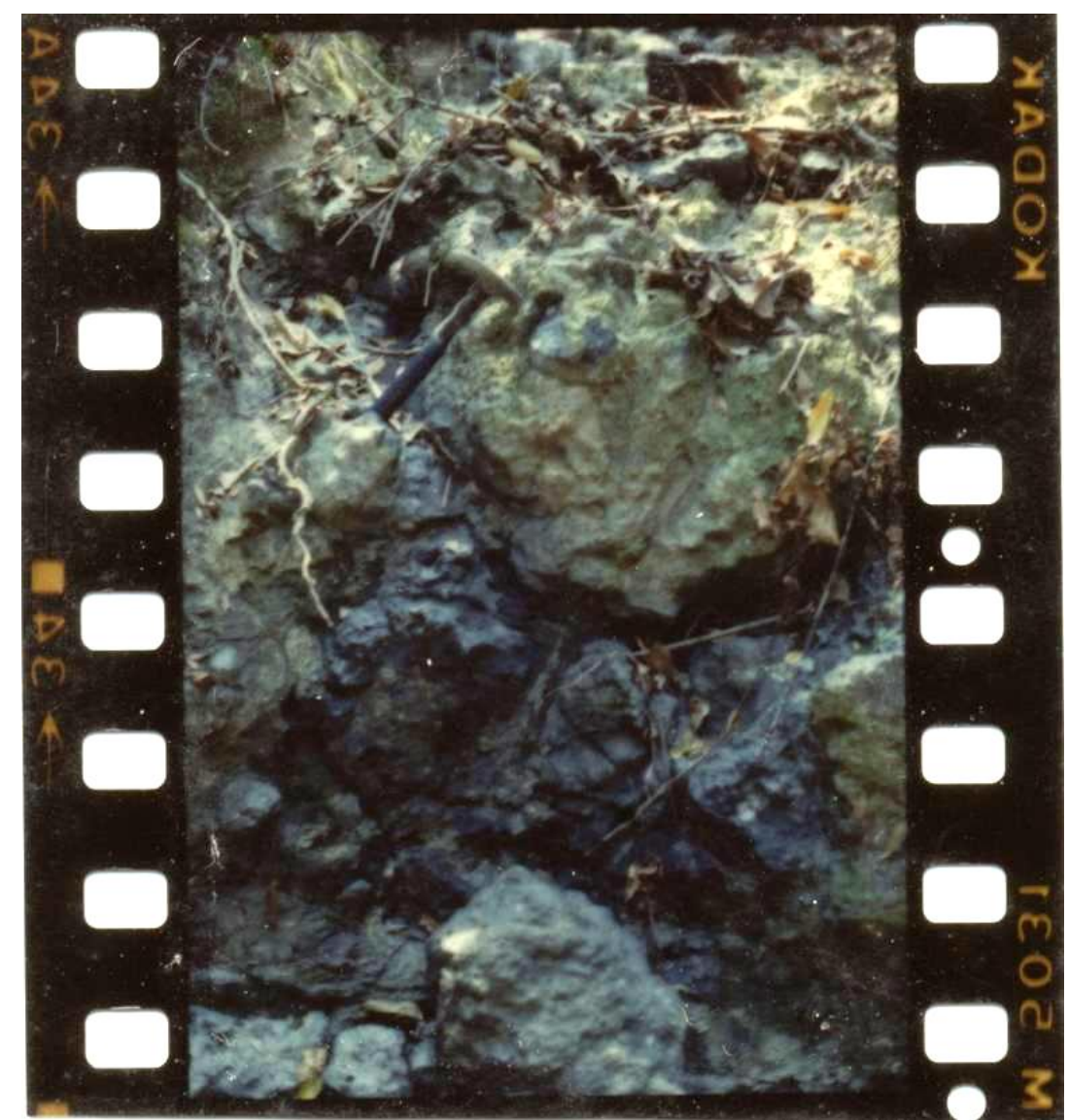

Figura 2 - Afloramento original do Kimberlito Indaiá em foto tomada em julho de 1975 pelo Prof. Darcy P. Svisero.

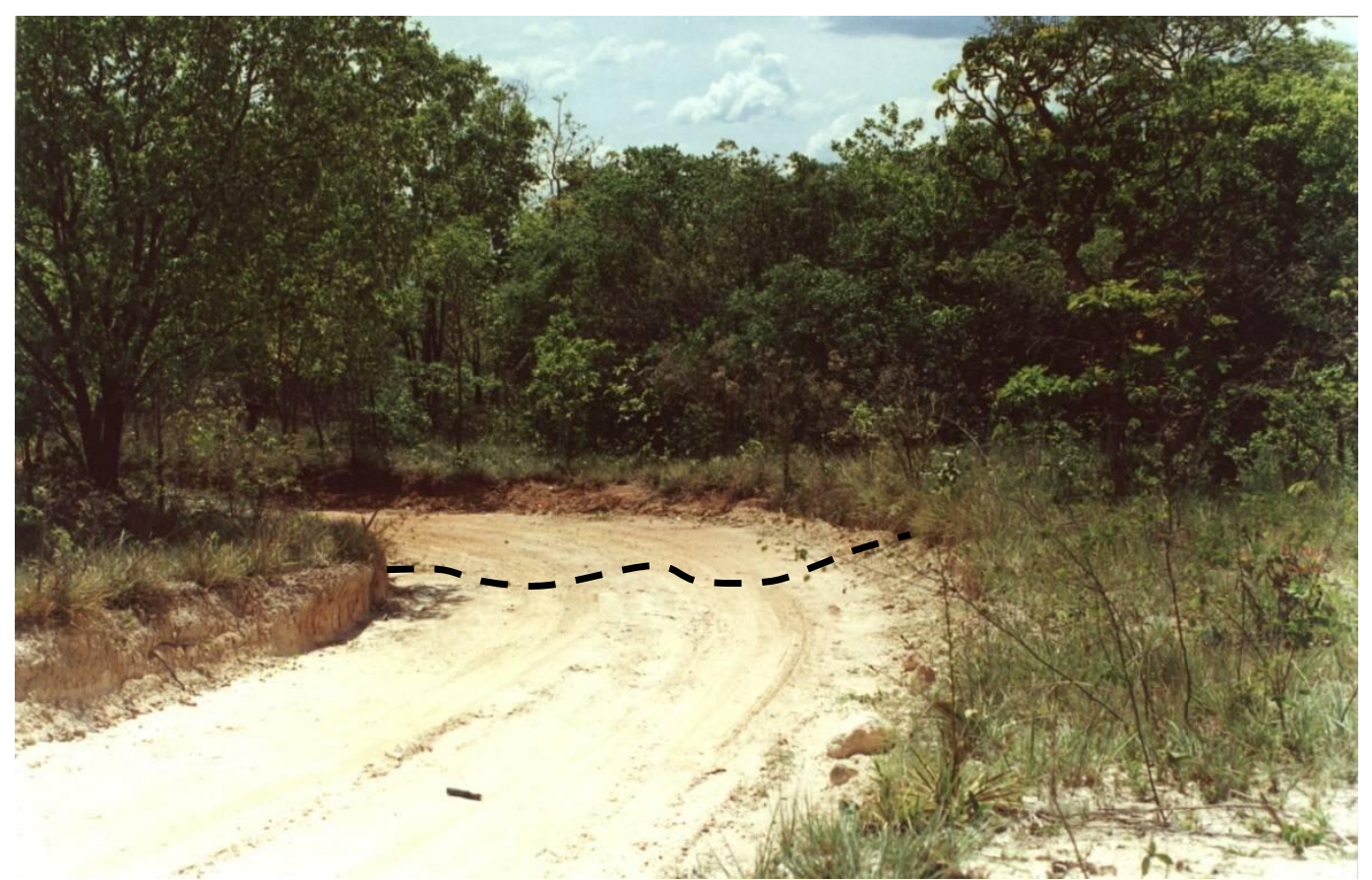

Figura 3 - Contraste entre os solos castanho avermelhado do Kimberlito Indaiá e o solo branco da encaixante granítica, conforme delineado na foto. 


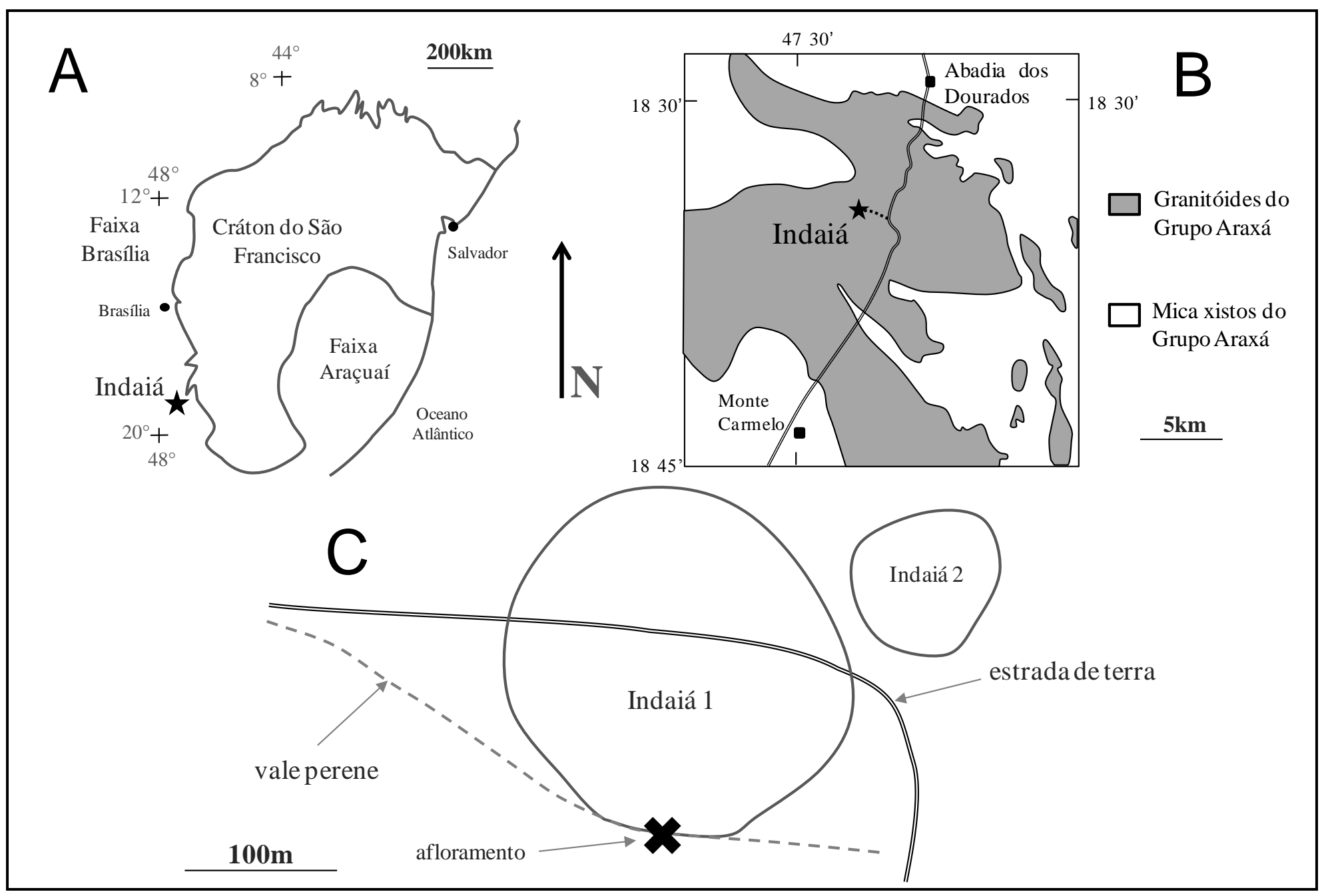

Figura 4- Contexto geológico do Kimberlito Indaiá. A) Posicionamento do corpo em relação ao Cráton São Francisco; B) Posicionamento do Kimberlito Indaiá em relação às rochas encaixantes; e C) Forma do corpo em superfície, com local de afloramento e posição em relação à estrada de terra e o vale perene adjacente. 


\section{MATERIAIS E MÉTODOS}

As atividades desenvolvidas para a realização da presente dissertação incluem levantamento bibliográfico, trabalho de campo, amostragem e trabalhos em laboratório, como detalham os itens a seguir.

\subsection{Trabalho de campo e amostragem}

No mês de abril de 2009, foi feito um trabalho de campo pela região SW de Minas Gerais, nas proximidades da cidade de Monte Carmelo visando a observação e coleta de amostras do corpo Indaiá, contando com o auxílio do Prof. Darcy P. Svisero e do técnico de mineração Luiz Alberto. Com o auxílio de uma marreta e de um martelo foram retiradas amostras do afloramento que continha xenólitos e megacristais. Estas amostras foram serradas para que pudessem ser identificados outros xenólitos em seus interiores. Assim, todos os xenólitos encontrados, totalizando 53 exemplares, foram fotografados e classificados por cor, tamanho, forma entre outras características, como será apresentado no item 3.4. desta dissertação.

\subsection{Técnicas analíticas}

\subsubsection{Microscopia óptica}

Esta técnica, que usa como base as propriedades ópticas dos minerais, é fundamental no campo da mineralogia e petrologia, e foi exaustivamente empregada neste trabalho, com a finalidade de identificar a mineralogia e texturas dos xenólitos, sendo um primeiro passo antes de usar metodologias mais avançadas.

Do conjunto mencionado no item 2.1. foram selecionadas 27 amostras de xenólitos e encaminhados para o laboratório de preparação de seções para a microssonda eletrônica do IGc-USP, onde foram confeccionadas seções delgadas, com espessura de $80 \mu \mathrm{m}$. Para tal fim foram adotados os seguintes procedimentos:

- Corte dos tabletes com serra diamantada, carbeto de silício (320) e água;

- Desbaste dos tabletes com rebolo diamantado, carbeto de silício (320) e água;

- Polimento dos tabletes com carbeto de silício (600) e água;

- Corte de $5 \mathrm{~mm}$ do tablete colado à lâmina;

- Prensagem, cerca de 3 horas, para retirar o excesso de cola e bolhas de ar a uma temperatura de $60^{\circ} \mathrm{C}$;

- Colagem dos tabletes às lâminas com araldite após banho com carbeto seco (600);

- Desbaste em prato de ferro, no jigue, com carbeto de silício até atingir espessura de $80 \mu \mathrm{m}$ 
- Polimento em prato com pano de alumina (0,05 microns) e pasta de alumina.

Uma vez confeccionadas, as seções foram observadas utilizando os microscópios binoculares Zeiss Axioplan e Olympus BXP-50, e descritas segundo suas características.

Fotomicrografias foram obtidas por meio de uma câmera da marca Canon de 4.1 Megapixels acoplada a um microscópio Olympus BXP-50 e a uma lupa Olympus SZH10. Para uma representação por completo das seções foi utilizado um Scanner de alta resolução da marca HP.

Análises modais das amostras foram obtidas pela contagem de pontos em folha impressa com imagem de alta resolução, em uma grade com espaçamento de cerca de 0,37 $\mathrm{mm}$ para os exemplares com granulometria mais fina e de $0,56 \mathrm{~mm}$ para as amostras que apresentam granulometria mais grossa. Em paralelo foram feitos testes da eficiência do método pela comparação com o método de contagem de pontos no microscópio petrográfíco com charriot e contador de pontos. Foi constatado que os valores das porcentagens minerais não sofreram muita variação entre um método e outro, porém foi possível notar que no primeiro, em folha impressa, os erros operacionais foram minimizados em relação à contagem pelo charriot.

\subsubsection{Microscópio eletrônico de varredura (MEV)}

Para a identificação de minerais opacos por análises semi-quantitativas e obtenção de imagens retroespalhadas a fim de identificar heterogeneidades nos minerais, foram utilizados o microscópio eletrônico de varredura Stereoscan S440 (Leo) com sistemas de microanálise INCA (EDS/WDS, marca Oxford) e de análises de imagens QWin Pro (Leica) do Laboratório de Caracterização Tecnológica do Departamento de Engenharia de Minas e de Petróleo da Escola Politécnica da USP e o microscópio LEO-440I com sistemas de microanálise INCA (EDS/WDS, marca Oxford) do Departamento de Geologia Sedimentar e Ambiental do

Instituto de Geociências da USP. A voltagem utilizada nos equipamentos foi de $20 \mathrm{kv}$ e corrente de feixe eletrônico de 20 ๆA .

\subsubsection{Microssonda eletrônica}

A microssonda eletrônica é um método analítico que permite a visualização do material e análises pontuais em minerais, sendo uma técnica não destrutiva que é amplamente utilizada no campo da geologia, como apresentado por Gomes \& Girardi (1973). O aparelho 
contém um canhão eletrônico que emite um feixe de elétrons que incide sobre a superfície da amostra, que em resposta emite raios $\mathrm{X}$ característicos, que são recebidos e analisados em espectrômetros acoplados ao conjunto. A obtenção de resultados quantitativos exige a realização de calibrações dos elementos a serem analisados através de uma amostra padrão, obedecendo à sequência padrão-amostra-padrão. Os padrões utilizados para cada elemento analisado estão apresentados na Tabela 1.

Neste trabalho as análises químicas quantitativas de minerais foram realizadas no Laboratório de Microssonda Eletrônica do Departamento de Mineralogia e Geotectônica do Instituto de Geociências da USP, pelo aparelho da marca JEOL modelo JXA-8600S, que contém 5 espectrômetros de dispersão de comprimento de onda (WDS), cada qual com dois cristais analisadores, com automação de fabricação NORAN, e sistema Voyager 3.6.1.

Todas as amostras foram recobertas com carbono em vácuo. As análises foram efetuadas com um potencial de $15 \mathrm{kv}$ e uma corrente de cerca de $20 \eta \mathrm{A}$ e diâmetro de $5 \mu \mathrm{m}$ para todos os minerais analisados. Os tempos de integração de contagem estiveram entre 10 e 30 segundos. Foram realizadas correções de efeito da matriz (número atômico, absorção de massa e fluorescência secundária) com o procedimento PROZA (Bastin et al., 1984). Os erros máximos estimados variam entre 1 e $2 \%$ para os elementos maiores, são da ordem de $5 \%$ para os menores (1-3\% em peso do elemento).

Para o tratamento dos dados e apresentação dos diagramas de composição química foram utilizados os programas MINPET ${ }^{\circledR}$ de Richard (1995) e Microsoft Excel ${ }^{\circledR}$. Para a obtenção de temperaturas de equilíbrio foi utilizada a planilha PTELX, baixada gratuitamente no site: www.mineralogie.uni-frankfurt.de/petrologie-geochemie. 
Tabela 1- Padrões químicos utilizados para todos os minerais analisados.

\begin{tabular}{cc}
\hline Elemento & Padrão \\
\hline $\mathrm{Nb}$ & Nióbio metálico \\
$\mathrm{Si}$ & Wollastonita \\
$\mathrm{Ti}$ & Rutilo \\
$\mathrm{Zr}$ & Zircônio metálico \\
$\mathrm{Al}$ & Anortita \\
$\mathrm{Cr}$ & Óxido de Crômio $\left(\mathrm{Cr}_{2} \mathrm{O}_{3}\right)$ \\
$\mathrm{Mg}$ & Diopsídio \\
$\mathrm{Ca}$ & Wollastonita \\
$\mathrm{Mn}$ & Olivina \\
$\mathrm{Fe}$ & Olivina \\
$\mathrm{Sr}$ & Silicato de Sr (SRAN) \\
$\mathrm{Ba}$ & Silicato de Bário natural \\
$\mathrm{Na}$ & Albita \\
$\mathrm{K}$ & Asbesto \\
$\mathrm{La}$ & Vidro terras raras REE3 \\
$\mathrm{Ce}$ & Vidro terras raras REE3 \\
$\mathrm{Ni}$ & Óxido de Ni (NiO) \\
$\mathrm{Zn}$ & Óxido de Zn (ZnO) \\
\hline
\end{tabular}




\section{PETROGRAFIA}

Este capítulo apresenta as informações sobre a classificação mineralógica e textural macro e microscópica dos xenólitos do Kimberlito Indaiá. São mostradas com detalhes aqui as informações apresentadas em Nannini et al. (2010a).

\subsection{Os xenólitos do Kimberlito Indaiá}

Os xenólitos de natureza mantélica representam de 2 a $5 \%$ do volume total do Kimberlito Indaiá. Dentro do conjunto de xenólitos mantélicos coletados neste trabalho predominam os harzburgitos, com $41 \%$ em volume, seguidos por lherzolitos (37\%), dunitos (14\%), mica piroxenitos (6\%) e xenólito polimítico (2\%). Estes nódulos apresentam dimensões entre 1,2 e $10 \mathrm{~cm}$. A presença de espinélio e flogopita é importante nestas rochas, porém estes minerais são mutuamente exclusivos em cada amostra. Levando em conta todos os xenólitos de peridotitos estudados, o espinélio, quando presente, pode apresentar forma idiomórfica, subidiomórfica e xenomórfica intersticial. A sua coloração varia de marrom avermelhado a marrom escuro, refletindo composições diferentes de acordo com a amostra. A flogopita, quando presente, exibe coloração marrom, ocorrendo sob a forma de pequenas venulações, intersticial ou em agregados intergranulares. Este último tipo geralmente ocorre associado com ilmenita, cromita e/ou magnetita em seu centro. Algumas amostras contêm clinopiroxênio idiomórfico a subidiomórfico, com coloração variando de verde esmeralda a verde pálido.

Além dos xenólitos mantélicos, foram identificados alguns xenólitos crustais representados por granitóides semi-alterados provenientes das encaixantes. Outros enclaves presentes no kimberlito são os autólitos, cujas dimensões máximas variam de $1,5 \mathrm{~cm}$ a $7 \mathrm{~cm}$. Essas rochas em geral apresentam matriz muito fina, com mega e macrocristais de olivina e/ou carbonato de até $1 \mathrm{~cm}$, podendo apresentar foliação de fluxo magmático ou aspecto de brecha.

\subsection{Tipos de xenólitos mantélicos}

Segundo Dawson (1980), os xenólitos mantélicos mais comuns são peridotitos, piroxenitos, eclogitos, glimeritos, suíte MARID e peridotitos metassomatizados. De acordo com a nomenclatura de Streckeisen (1976), os peridotitos são representados por dunitos (olivina), harzburgitos (olivina+ortopiroxênio), wehrlitos (olivina+clinopiroxênio) e lherzolitos (olivina+ortopiroxênio+clinopiroxênio); os piroxenitos por sua vez, podem ser 
divididos em ortopiroxenitos, clinopiroxenitos e websteritos (ortopiroxênio+clinopiroxênio). Tanto os peridotitos quanto os piroxenitos podem constituir associações com espinélio ou com granada, dependendo das condições de pressão e temperatura. Quanto aos eclogitos, estes são formados principalmente por granada (piropo-almandina) e piroxênio (onfacita), além de fases acessórias tais como coríndon, cianita, rutilo e diamante, entre outras. Suítes relacionadas ao metassomatismo mantélico e a magmas kimberlíticos são representadas por glimeritos, suíte MARID e suíte PIC (Grégoire et al. 2002). Glimeritos são constituídos predominantemente por flogopita (>90\%), podendo conter anfibólio, clinopiroxênio, ilmenita, rutilo, apatita e olivina. A suíte MARID reúne xenólitos constituídos pela associação mica+anfibólio+rutilo+ilmenita+diopsídio e a suíte PIC reúne espécies com a associação mineral flogopita+ilmenita+clinopiroxênio. Peridotitos metassomatizados reúnem minerais com evidências de ação metassomática tais como flogopita, ilmenita, rutilo, sulfetos, richterita, carbonato, entre outros. Xenólitos exóticos com mineralogia e texturas compostas, representando mais de um tipo na mesma amostra, representam xenólitos polimíticos.

O trabalho de Pearson et al. (2003) separa os diferentes tipos de xenólitos em dois ambientes tectônicos: cratônicos/circo-cratônicos, que são amostrados por rochas vulcânicas de afinidade kimberlítica, e não cratônicos, que são amostrados por rochas vulcânicas máficas alcalinas ou potássicas. Do primeiro grupo fazem parte: peridotitos de granulação grossa, de baixa temperatura, ricos em $\mathrm{Mg}(\# \mathrm{Mg}=0,91-0,95)$; peridotitos e piroxenitos de granulação grossa, baixa temperatura, ricos em $\mathrm{Fe}(\# \mathrm{Mg}=0,83-0,89)$; dunitos; peridotitos e piroxenitos deformados, de baixa temperatura; peridotitos deformados de alta temperatura; xenólitos mantélicos máficos ricos em flogopita; lentes de piroxenito ricas em $\mathrm{Fe}$ e $\mathrm{Ti}$; peridotitos modalmente metassomatizados; eclogitos, grospiditos, alkremitos e variantes; megacristais; agregados polimíticos; diamantes e inclusões em diamantes; peridotitos ultra-profundos. Já o grupo dos xenólitos não cratônicos engloba Cr-diopsídio lherzolitos; Al-augita werhlitos e Alaugita piroxenitos; granada piroxenito; xenólitos com metassomatismo modal; megacristais.

\subsection{Classificação mineralógica dos xenólitos mantélicos}

A composição mineralógica e a classificação das rochas estudadas é mostrada na Figura 5, seguindo os critérios de Streckeisen (1976). Como pode ser observado na Figura 5, o Kimberlito Indaiá apresenta como xenólitos dunitos, harzburgitos e lherzolitos, porém a 
grande maioria dos pontos está situada na porção superior esquerda do diagrama, e indica uma tendência harzburgítica para estes xenólitos. Por não existir uma classificação e nomenclatura universal para xenólitos contendo mica (Grégoire et al., 2002), foi adotado neste trabalho o termo mica piroxenito para duas amostras, de código In1/24b e In1/31 que apresentam predominantemente ortopiroxênio, flogopita e minerais opacos.

Uma outra amostra, de código In1/6, contendo olivina, ilmenita, clinopiroxênio e flogopita, por suas características texturais complexas, foi classificada como xenólito polimítico.

Os mica piroxenitos e xenólito polimítico estudados também têm suas composições projetadas no diagrama da Figura 5, porém somente para comparar a proporção entre olivina, ortopiroxênio e clinopiroxênio. 

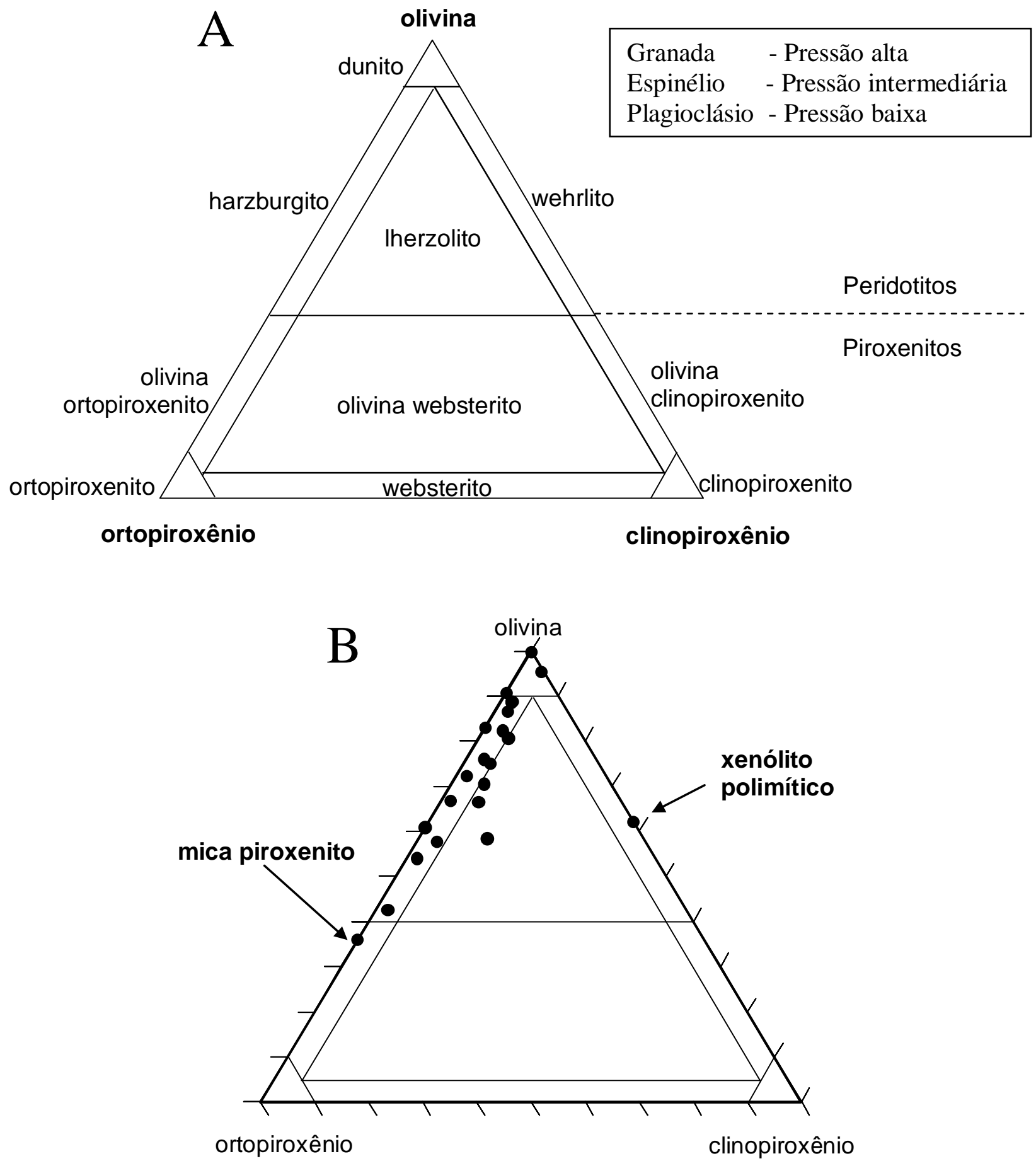

Figura 5 - A) Classificação de rochas ultramáficas segundo Streckeisen (1976). B) Classificação mineralógica dos xenólitos do Kimberlito Indaiá estudados neste trabalho. Destaca-se a tendência harzburgítica dos xenólitos. 


\subsection{Classificação textural de peridotitos}

Os xenólitos mantélicos exibem aspectos texturais muito variados, que registram processos de deformação, recristalização e crescimento de cristais no manto. São numerosos os trabalhos que oferecem esquemas de classificação e nomenclatura para xenólitos (Mercier \& Nicolas 1975, Nixon \& Boyd 1973a, Cox et al.1973, Boullier \& Nicolas 1975, Pike \& Schwarzman, 1977; Harte 1977), em alguns casos incorporando critérios mineralógicos e químicos além dos propriamente texturais. Alguns exemplos dos termos que já foram utilizados para descrição textural de xenólitos peridotíticos são sumarizados na Tabela 3.

O trabalho de Harte (1977) foi resultado de uma ampla discussão com pesquisadores de renome na literatura sobre xenólitos, kimberlitos, etc., realizada durante um Seminário organizado pela empresa De Beers, em Cambridge, no ano de 1975, e inclui definição de termos, nomenclatura das texturas de xenólitos, interrelações e subtipos, assim como referências a descrições anteriores de trabalhos como Cox et al. (1973), Nixon \& Boyd (1973a), Mercier \& Nicolas (1975), Boullier \& Nicolas (1975) e Pike \& Schwarzman (1977). Por ter sido o último artigo que abordou, de uma forma equilibrada, a nomenclatura de texturas em xenólitos peridotíticos, levando em conta os principais trabalhos prévios e contemporâneos no assunto, o presente trabalho utilizar-se-á da nomenclatura proposta por Harte (1977) para os xenólitos peridotíticos estudados. A seguir estão os critérios de classificação para a nomenclatura sugerida por Harte (op. cit.).

\subsubsection{Textura grossa (coarse)}

Corresponde à textura protogranular de Mercier \& Nicolas (1975) e às texturas denominadas de granular (Nixon \& Boyd 1973a) e tem equivalência com as texturas ígneas, pirometamórfica e alotriomórfica, empregadas por Pike \& Schwarzman (1977). Os minerais mais abundantes são de granulação grossa (maiores que $2 \mathrm{~mm}$ ) e podem exibir evidências de deformação e apresentar recristalização parcial, porém não ocorrem porfiroclastos.

Segundo Mercier \& Nicolas (op. cit.), que estudaram xenólitos lherzolíticos em álcalibasaltos do oeste europeu e do Hawaí, o ortopiroxênio e a olivina são tipicamente grossos, com presença de kink-bands $(\mathrm{KB})$ nos cristais de olivina. A olivina e o ortopiroxênio têm contatos curvos entre si, exceto quando há recristalização entre os grãos (o que gera agregados em forma de mosaico). Os cristais de clinopiroxênio e espinélio (em torno de $1 \mathrm{~mm}$ ) são em geral menores que a olivina e o ortopiroxênio, e estão na maior parte das vezes em contato 
direto com os grãos de ortopiroxênio maiores. Localmente o clinopiroxênio pode ocorrer em forma de gotas (blebs) nas porções periféricas dos grãos de ortopiroxênio, enquanto o espinélio pode ter forma vermicular, ocorrendo dentro do ortopiroxênio ou entre o ortopiroxênio e "gotas" de clinopiroxênio, intersticial ou bem cristalizado formando polígonos.

Harte (op.cit.) sugere dois subtipos para a textura grossa: grossa equidimensional (equant-coarse) e grossa tabular (tabular-coarse), com base no trabalho de Boullier \& Nicolas (1975) com xenólitos de kimberlitos sul-africanos. A textura grossa equidimensional (denominada anteriormente como coarse granular por Boullier \& Nicolas, op.cit.) é caracterizada por apresentar um formato isométrico dos cristais (com até $6 \mathrm{~mm}$ ) e ausência de foliação. Já a textura grossa tabular conta com grãos em forma tabular (5 x 2 mm) e presença de forte foliação.

\subsubsection{Textura porfiroclástica}

Inicialmente chamada por Boyd \& Nixon (1973a) de cisalhada (sheared) ou flaser por Cox et al. (1973), corresponde-se com a descrição de Mercier \& Nicolas (op.cit). Esta textura exibe duas classes de cristais de olivina e enstatita: grãos grandes com evidências de deformação (porfiroclastos, com até $8 \mathrm{~mm}$ ) e grãos menores sem deformação, com contornos retos (neoblastos, com cerca de $0,5 \mathrm{~mm}$ ), junto com os pequenos grãos xenomórficos de outros minerais (clinopiroxênio e espinélio). Em particular, o espinélio apresenta uma textura típica chamada de holly-leaf (forma da folha de azevinha) e ocorre achatado paralelamente aos porfiroclastos. Os porfiroclastos, comumente achatados, conferem marcada foliação às rochas. A matriz pode ser descrita como muito fina $(<0,1 \mathrm{~mm})$, fina (entre 0,1 e $0,5 \mathrm{~mm}) \mathrm{e}$ média (>0,5 mm). Quando a rocha possui mais de $90 \%$ de olivina com granulação fina e textura em mosaico (neoblastos), denomina-se porfiroclástica em mosaico (mosaicporphyroclastic) para ressaltar o grau de recristalização da rocha.

Segundo Harte (op.cit.), dentro dos grupos porfiroclástico e porfiroclástico em mosaico podem ocorrer as texturas desagregada (disrupted), fluidal e/ou laminada. Diz-se textura desagregada quando o espinélio ou a granada ocorrem em grupos de pequenos grãos que sugerem ser resultado da desagregação de um grão maior prévio. A textura fluidal é observada quando pequenas tiras ou lentículas de um mineral $(0,01$ a $0,03 \mathrm{~mm})$ são conectadas com um porfiroclasto do mesmo mineral e avançam entre zonas onde outro 
mineral apresenta uma textura em mosaico predominante. Já a textura laminada, ou bandada (banded, por Dawson et al., 1975), é diagnosticada quando uma rocha mostra camadas finas $(<2,5 \mathrm{~mm})$ ou lentículas associadas a variações modais (principalmente em olivina e ortopiroxênio), dando um aspecto de bandamento composicional milonítico.

\subsubsection{Textura granoblástica}

Nesta textura o tamanho dos grãos costuma ser em torno de $2 \mathrm{~mm}$ e menor que $1 \mathrm{~mm}$ em xenólitos de basaltos (Mercier \& Nicolas, 1975) e os porfiroclastos não ultrapassam 5\% em volume na rocha, em virtude da forte recristalização. O espinélio pode ocorrer preferencialmente em formas arredondadas incluso em olivina ou piroxênio, como conseqüência da deformação, recristalização e crescimento de grãos (Mercier \& Nicolas, op.cit.). É equivalente à textura equigranular de Mercier \& Nicolas (op. cit.) e às texturas foliadas e equigranular em mosaico de Schwarzman \& Pike (1977).

Os subtipos desta textura são granoblástica equidimensional e granoblástico tabular (Harte, 1977), correspondentes respectivamente às texturas equigranular em mosaico e equigranular tabular de Mercier \& Nicolas (op. cit.). A primeira apresenta olivina, ortopiroxênio e clinopiroxênio na forma de polígonos regulares; já a textura granoblástica tabular apresenta olivina, ortopiroxênio e clinopiroxênio tabulares com 0,5 a 1,4 mm, definindo uma foliação forte.

\subsubsection{Texturas transicionais}

Mercier \& Nicolas (1975) mencionam tipos texturais que representam a transformação entre as texturas grossa (protogranular) e porfiroclástica, e entre porfiroclástica e granoblástica. Neste trabalho, para efeito de classificação, o termo transicional não será utilizado, somente o nome da textura predominante. 
Tabela 2- Nomenclatura utilizada para a classificação textural de xenólitos peridotíticos segundo vários autores. As cores utilizadas nesta tabela indicam semelhanças descritivas entre as texturas identificadas e nomeadas pelos diferentes autores.

\begin{tabular}{|c|c|c|c|c|c|c|c|c|c|c|}
\hline Referências & $\begin{array}{c}\text { Nixon \& Boyd } \\
\text { (1973) }\end{array}$ & $\begin{array}{c}\text { Cox et } \\
\text { al. (1973) }\end{array}$ & $\begin{array}{c}\text { Mercier \& Nicolas } \\
(1975)\end{array}$ & \multicolumn{2}{|c|}{$\begin{array}{c}\text { Boullier \& Nicolas } \\
\text { (1975) }\end{array}$} & $\begin{array}{c}\text { Pike \& Schwarzman } \\
(1977)\end{array}$ & \multicolumn{4}{|c|}{ Harte (1977) } \\
\hline \multirow{9}{*}{ Texturas } & \multirow{3}{*}{ Granular } & \multirow{3}{*}{$\begin{array}{l}\text { Coarse- } \\
\text { grained }\end{array}$} & \multirow{3}{*}{ Protogranular } & \multirow{2}{*}{\multicolumn{2}{|c|}{ Grossa granular }} & Ígnea & \multicolumn{4}{|c|}{ Grossa (coarse) } \\
\hline & & & & & & Pirometamórfica & & & & \\
\hline & & & & Gros & tabular & $\begin{array}{c}\text { Alotriomórfica } \\
\text { Granular }\end{array}$ & Equiamints & (equalin) & & (1) \\
\hline & & & & Porf & clástica & & & Porfiroc & tica & \\
\hline & Cisalhados & Flaser & Porfiroclástica & & aico & Porfiroclástica & 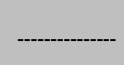 & Disrupta & Fluidal & $\begin{array}{l}\text { Laminada e } \\
\text { Desagragada }\end{array}$ \\
\hline & & & & & & & & oclástica & mosa & \\
\hline & & & & Normal & Fluidal & Cataclástica & & Fluidal & $\begin{array}{r}\mathrm{La} \\
\mathrm{De}\end{array}$ & $\begin{array}{l}\text { inada e } \\
\text { agragada }\end{array}$ \\
\hline & & & Equigranular & Tabula & ecundária & Foliada & & Granobl & tica & \\
\hline & & & \begin{tabular}{l|l} 
Tabular & Mosaico \\
\end{tabular} & & & mosaico & Equidimens & (equant) & & abular \\
\hline
\end{tabular}

Tabela 3- Classificação de Harte (1977) para peridotitos mantélicos, segundo a textura.

\begin{tabular}{|c|c|c|c|c|}
\hline Tipo de textura da rocha & Porfiroclastos & Tamanho dos grãos & Contato entre os grãos & $\begin{array}{l}\text { Subtipos de } \\
\text { texturas }\end{array}$ \\
\hline Grossa (coarse) & ausentes & $\begin{array}{l}\text { em média os grãos } \\
\text { são }>2 \mathrm{~mm}\end{array}$ & $\begin{array}{c}\text { podem ser retilínios, } \\
\text { ligeiramente curvos ou } \\
\text { irregulares }\end{array}$ & $\begin{array}{c}\text { equigranular / } \\
\text { tabular }\end{array}$ \\
\hline Porfiroclástica & $\begin{array}{c}\text { mais de } 10 \% \text { da olivina } \\
\text { ocorre como porfiroclastos }\end{array}$ & $\begin{array}{l}\text { porfiroclastos e } \\
\text { matriz fina }\end{array}$ & $\begin{array}{l}\text { irregular em porfiroblastos e } \\
\text { reta em neoblastos }\end{array}$ & $\begin{array}{l}\text { fluidal / } \\
\text { disrupta / } \\
\text { laminada }\end{array}$ \\
\hline $\begin{array}{c}\text { Porfiroclástica em } \\
\text { mosaico }\end{array}$ & $\begin{array}{l}\text { menos de } 10 \% \text { da olivina } \\
\text { ocorre como porfiroclastos }\end{array}$ & $\begin{array}{l}\text { porfiroclastos e } \\
\text { matriz fina }\end{array}$ & $\begin{array}{l}\text { irregular em porfiroblastos e } \\
\text { reta em neoblastos }\end{array}$ & $\begin{array}{c}\text { fluidal/ } \\
\text { desagregada } \\
\text { /laminada }\end{array}$ \\
\hline Granoblástica & raro a ausente & $\begin{array}{l}\text { maioria dos grãos } \\
<2 \mathrm{~mm}\end{array}$ & $\begin{array}{l}\text { contatos retilíneos a pouco } \\
\text { curvos, grãos poligonizados }\end{array}$ & $\begin{array}{l}\text { equigranular / } \\
\text { tabular }\end{array}$ \\
\hline
\end{tabular}




\subsection{Classificação petrográfica dos xenólitos do Kimberlito Indaiá}

Uma população de 53 amostras, incluindo xenólitos, macrocristais, megacristais e autólitos coletados do Kimberlito Indaiá, foi classificada por critérios físicos, como dimensão do lado maior, forma, cor, estrutura; e por critérios mineralógicos, como mineralogia, classificação litológica (Streckeisen 1976, Mitchell 1986) e texturas (Harte 1977), como é apresentado na Tabela 4. Nesta população há um franco predomínio de xenólitos mantélicos em relação aos crustais. Estes xenólitos, representados na Figura 6 e 7, apresentam características muito variadas, com tamanhos de 1,2 a $10 \mathrm{~cm}$; formas circulares, elipsoidais, subangulosas e angulosas; cor do preto ao verde amarelado claro; a estrutura é predominantemente maciça, mas algumas amostras contêm minerais que definem uma foliação. O mineral predominante é a olivina, seguida em abundância por ortopiroxênio, clinopiroxênio, espinélio, flogopita, minerais opacos, anfibólio e zircão. A granulometria das rochas varia de fina a grossa e a forma dos grãos varia de anedral a idiomórfica; as texturas presentes são grossa, porfiroclástica e granoblástica (Harte, 1977).

Os autólitos são muito frequentes no Kimberlito Indaiá, sendo mais abundantes que os xenólitos mantélicos, e exemplos representativos são ilustrados na Figura 6. Apresentam tamanho de 2,1 a $7 \mathrm{~cm}$; forma circular a amebóide; coloração verde a cinza claro; estrutura maciça ou foliação de fluxo magmático; matriz muito fina com mineralogia não identificada e macrocristais de olivina e carbonato.

Os macro e megacristais que ocorrem no Kimberlito Indaiá são de olivina, piroxênio, flogopita e ilmenita; apresentam forma elipsoídica a circular e tamanho que varia de 0,5 a 3,5 $\mathrm{cm}$.

As abreviações dos minerais na tabelas e nas fotos das amostras segue a proposta de Kretz (1983), na qual os minerais descritos estão com sua abreviação: Ol-olivina; Opxortopiroxênio; Cpx-clinopiroxênio; Spl-espinélio; Phl-flogopita; Ilm-ilmenita; Chr-cromita; Prg-pargasita; Zrn-zircão; Mag-magnetita; Prv-perovskita; Gn-galena. 


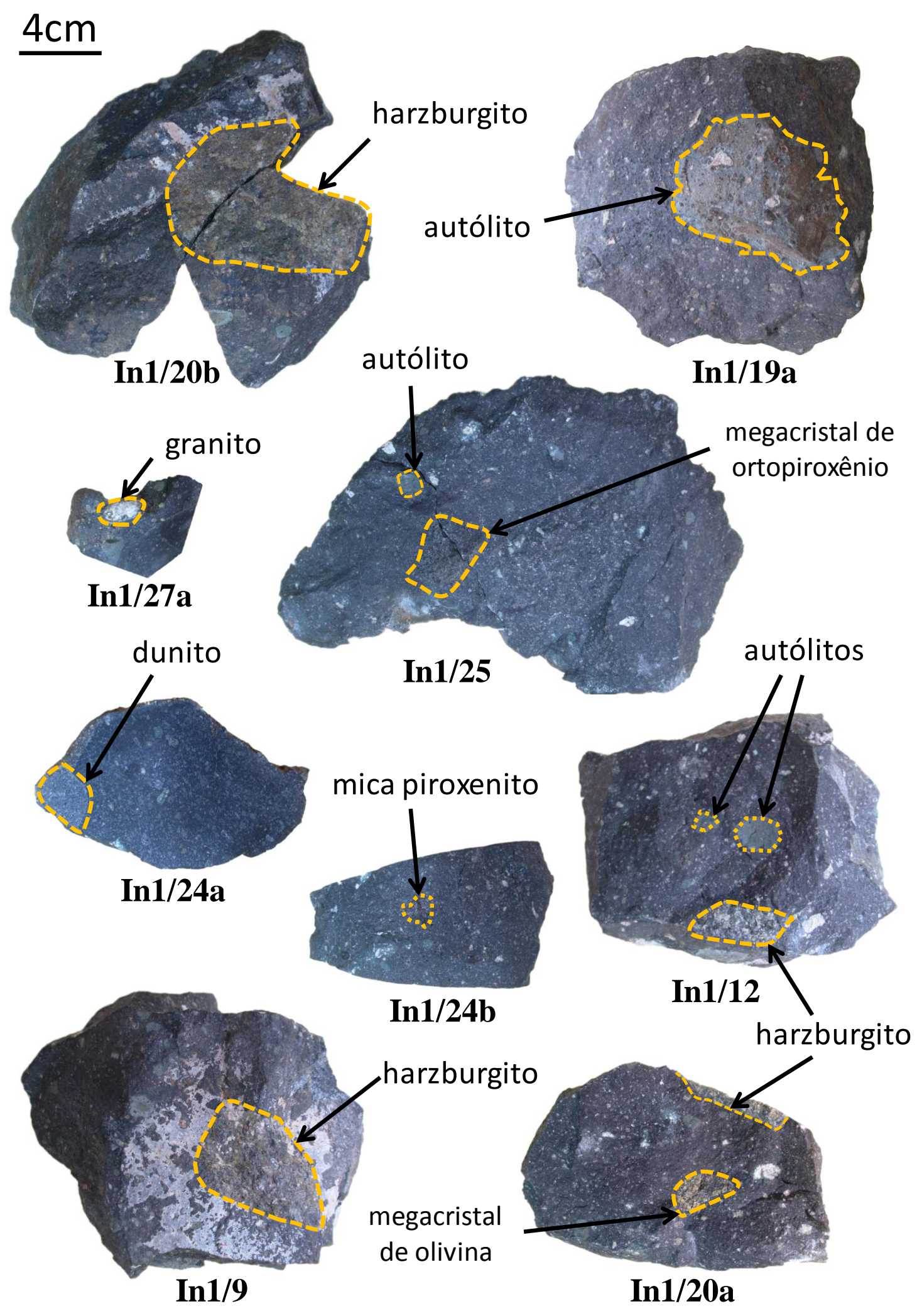

Figura 6- Exemplos representativos dos diversos tipos de xenólitos em amostras em meio à matriz do Kimberlito Indaiá. 


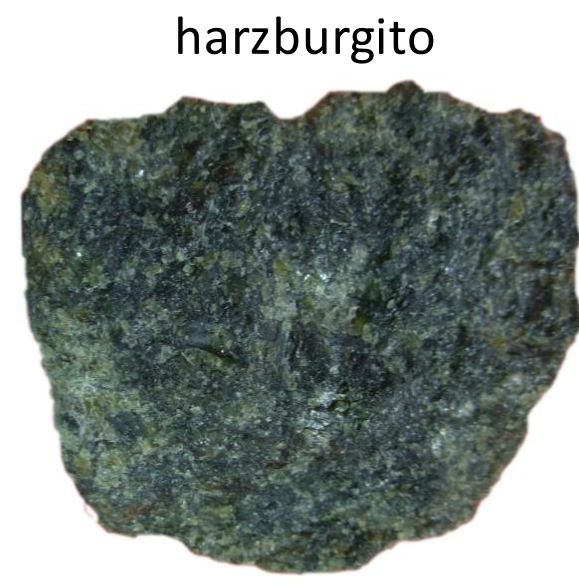

In1/1 granito

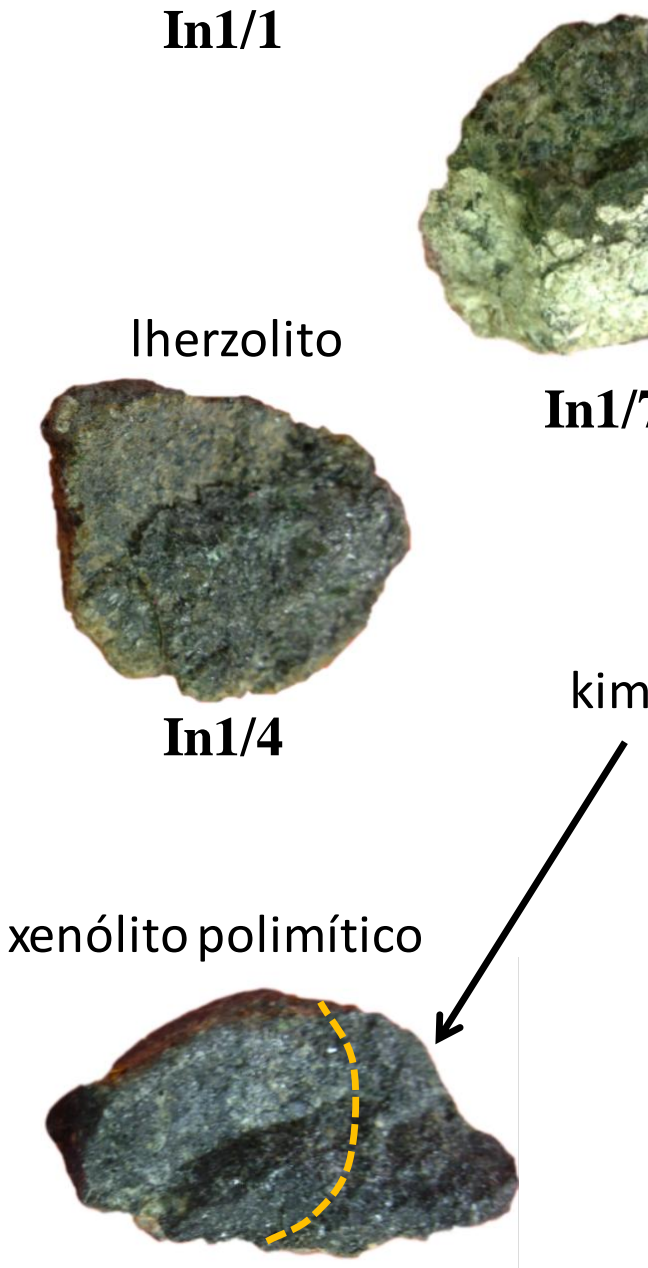

In1/6

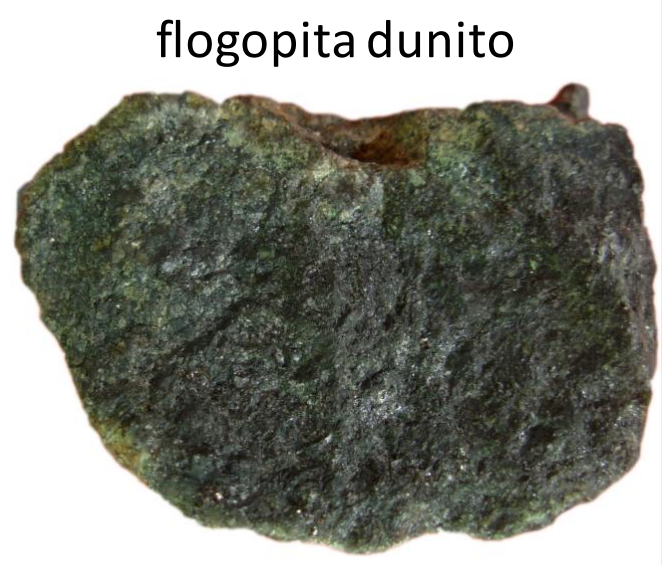

In1/2

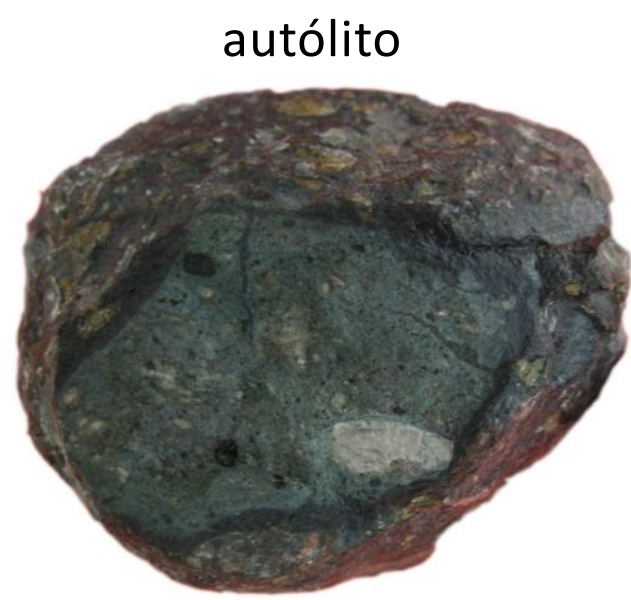

In1/11

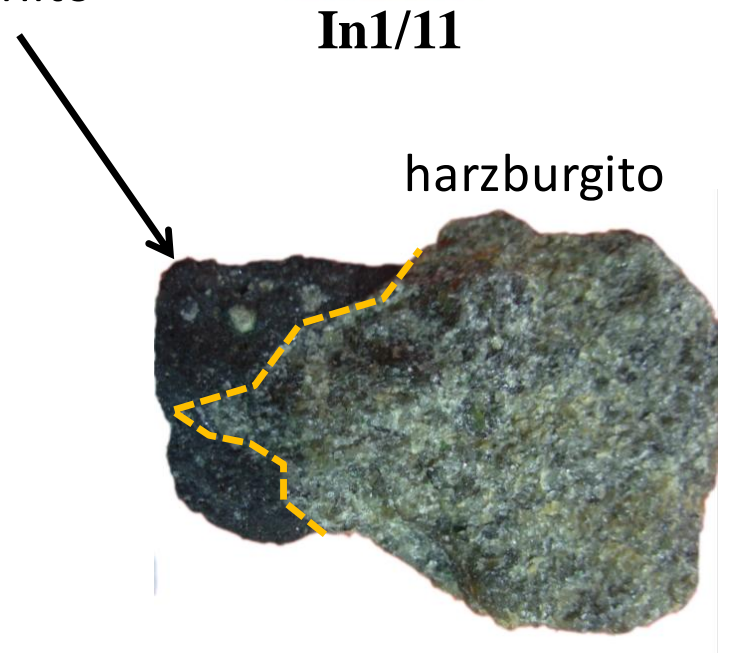

In1/3

Figura 7- Exemplos de xenólitos representativos do Kimberlito Indaiá. 
Tabela 4- Classificação tipológica dos enclaves estudados do Kimberlito Indaiá.

\begin{tabular}{|c|c|c|c|c|c|c|c|}
\hline $\begin{array}{l}\text { Código da } \\
\text { amostra }\end{array}$ & $\begin{array}{l}\text { Dimensão } \\
\text { máxima }\end{array}$ & Forma & Cor & Estrutura & Composição Mineralógica & Textura e granulação & Natureza \\
\hline In1/01 & $5 \mathrm{~cm}$ & $\begin{array}{l}\text { Ovalado e } \\
\text { facetado }\end{array}$ & $\begin{array}{l}\text { Cinza escuro } \\
\text { esverdeado }\end{array}$ & $\begin{array}{l}\text { Leve foliação definida pelo } \\
\text { Opx }\end{array}$ & $\begin{array}{l}\text { Olivina + ortopiroxênio + } \\
\text { flogopita }\end{array}$ & $\begin{array}{l}\text { Granular xenomórfica, grossa tabular; média a } \\
\text { grossa (ocorre também olivina muito fina } \\
\text { recristalizada nos contatos entre os minerais). }\end{array}$ & Harzburgito \\
\hline In1/02 & $4,5 \mathrm{~cm}$ & Circular & $\begin{array}{l}\text { Preto escuro } \\
\text { esverdeado }\end{array}$ & $\begin{array}{l}\text { Foliação definida pelas } \\
\text { micas }\end{array}$ & $\begin{array}{l}\text { Olivina }+ \text { flogopita }+ \\
\text { clinopiroxênio + ortopiroxênio }\end{array}$ & Granular xenomórfica, grossa; média a grossa & $\begin{array}{l}\text { Flogopita- } \\
\text { dunito }\end{array}$ \\
\hline In1/03 & $3,5 \mathrm{~cm}$ & Facetado & $\begin{array}{l}\text { Verde pálido a } \\
\text { cinza claro }\end{array}$ & $\begin{array}{l}\text { Leve foliação definida pelo } \\
\text { Opx e opacos }\end{array}$ & $\begin{array}{l}\text { Olivina + ortopiroxênio + } \\
\text { espinélio + clinopiroxênio }\end{array}$ & $\begin{array}{c}\text { Granular hipidiomórfica, granoblástica; média } \\
\text { a fina }\end{array}$ & Harzburgito \\
\hline In1/04 & $2,5 \mathrm{~cm}$ & Circular & $\begin{array}{l}\text { Cinza esverdeado } \\
\text { pálido }\end{array}$ & Maciça & $\begin{array}{l}\text { Olivina + ortopiroxênio + } \\
\text { clinopiroxênio + espinélio }\end{array}$ & $\begin{array}{l}\text { Inequigranular hipidiomórfica, porfiroclástica; } \\
\text { matriz fina a média e macrocristais grossos }\end{array}$ & Lherzolito \\
\hline In1/05 & $2 \mathrm{~cm}$ & Circular & Preto & Maciça & $\begin{array}{l}\text { Olivina + ortopiroxênio + } \\
\text { clinopiroxênio + flogopita }\end{array}$ & Granular xenomórfico, grossa; grossa & Harzburgito \\
\hline In1/06 & $2 \mathrm{~cm}$ & Circular & Preto & Maciça & $\begin{array}{l}\text { Olivina + minerais opacos + } \\
\text { clinopiroxênio + flogopita + } \\
\text { carbonato + zircão }\end{array}$ & $\begin{array}{l}\text { Intercrescimento gráfico e veio de flogopita; } \\
\text { fina a média }\end{array}$ & $\begin{array}{l}\text { Xenólito } \\
\text { Polimítico }\end{array}$ \\
\hline In1/07 & $2,5 \mathrm{~cm}$ & Circular & Branco & Maciça & Quartzo + feldspato (alterado) & Equigranular; fina & Granito \\
\hline In1/08 & $2,6 \mathrm{~cm}$ & Circular & Branco a bege & Maciça & Quartzo + feldspato (alterado) & Equigranular; fina & Granito \\
\hline In1/09 & $6 \mathrm{~cm}$ & Elipsoidal & $\begin{array}{l}\text { Verde claro } \\
\text { amarelado }\end{array}$ & Maciça & $\begin{array}{l}\text { Olivina + ortopiroxênio + } \\
\text { clinopiroxênio + espinélio }\end{array}$ & $\begin{array}{l}\text { Granular xenomórfica a hipidiomórfica, grossa; } \\
\text { grossa }\end{array}$ & Harzburgito \\
\hline In1/10 & $2,3 \mathrm{~cm}$ & Elipsoidal & Cinza esverdeado & $\begin{array}{l}\text { Leve foliação definida pelo } \\
\text { Opx }\end{array}$ & $\begin{array}{l}\text { Olivina + ortopiroxênio + } \\
\text { clinopiroxênio + espinélio }\end{array}$ & $\begin{array}{c}\text { Granular hipidiomórfica, grossa tabular; } \\
\text { média }\end{array}$ & Harzburgito \\
\hline In1/11 & $5,4 \mathrm{~cm}$ & Elipsoidal & $\begin{array}{l}\text { Cinza claro, com } \\
\text { minerais róseos }\end{array}$ & Foliação de fluxo & $\begin{array}{l}\text { Macrocristais de olivina e } \\
\text { carbonato em matriz não } \\
\text { identificada }\end{array}$ & Inequigranular seriada; matriz muito fina & Autólito \\
\hline In1/12 & $3 \mathrm{~cm}$ & Subanguloso & $\begin{array}{l}\text { Cinza esverdeado } \\
\text { pálido }\end{array}$ & Maciça & $\begin{array}{l}\text { Olivina + ortopiroxênio + } \\
\text { clinopiroxênio + flogopita }\end{array}$ & Granular xenomórfica, grossa; média a grossa & Harzburgito \\
\hline In1/13a & $2 \mathrm{~cm}$ & $\begin{array}{l}\text { Tabular } \\
\text { alongado }\end{array}$ & $\begin{array}{l}\text { Cinza esverdeado } \\
\text { escuro }\end{array}$ & Maciça & $\begin{array}{l}\text { Olivina + ortopiroxênio + } \\
\text { clinopiroxênio + espinélio }\end{array}$ & Granular xenomórfico, grossa; média & Lherzolito \\
\hline In1/13b & $1,5 \mathrm{~cm}$ & Anguloso & Verde & Maciça & $\begin{array}{l}\text { Olivina + ortopiroxênio + } \\
\text { clinopiroxênio }\end{array}$ & Granular xenomórfico, grossa; média & Harzburgito \\
\hline In1/14a & $4,5 \mathrm{~cm}$ & Circular & Verde claro & Maciça & $\begin{array}{l}\text { Olivina + ortopiroxênio + } \\
\text { clinopiroxênio + espinélio }\end{array}$ & $\begin{array}{c}\text { Granular hipidiomórfica, grossa; média a } \\
\text { grossa }\end{array}$ & Lherzolito \\
\hline In1/14b & $1,2 \mathrm{~cm}$ & Circular & $\begin{array}{l}\text { Verde } \\
\text { acinzentado }\end{array}$ & Maciça & $\begin{array}{l}\text { Olivina + ortopiroxênio }+ \\
\text { flogopita }+ \text { clinopiroxênio }\end{array}$ & Granular xenomórfico, grossa; média & Harzburgito \\
\hline In1/14c & $2,2 \mathrm{~cm}$ & $\begin{array}{l}\text { Elipse } \\
\text { alongado }\end{array}$ & Cinza esverdeado & Maciça & Olivina + minerais opacos & Granular xenomórfico, grossa; média & Dunito \\
\hline In1/15 & $2,5 \mathrm{~cm}$ & Elipsoidal & Verde escuro & Maciça & $\begin{array}{c}\text { Olivina + ortopiroxênio + } \\
\text { clinopiroxênio + minerais opacos }\end{array}$ & $\begin{array}{l}\text { Granular hipidiomórfica, granoblástica; fina a } \\
\text { média }\end{array}$ & Lherzolito \\
\hline
\end{tabular}

Observação: os termos em negrito do item "Texturas e granulação" correspondem aos termos da classificação de Harte (1977). 
Tabela 4 - Continuação.

\begin{tabular}{|c|c|c|c|c|c|c|c|}
\hline $\begin{array}{c}\text { Código da } \\
\text { amostra }\end{array}$ & $\begin{array}{l}\text { Dimensão } \\
\text { máxima }\end{array}$ & Forma & Cor & Estrutura & Composição Mineralógica & Textura e granulação & Natureza \\
\hline In1/16 & $2,8 \mathrm{~cm}$ & $\begin{array}{c}\text { Tabular } \\
\text { arredondado }\end{array}$ & Cinza esverdeado & $\begin{array}{l}\text { Foliação definida } \\
\text { pelos opacos }\end{array}$ & $\begin{array}{c}\text { Olivina }+ \text { ortopiroxênio }+ \\
\text { clinopiroxênio }+ \text { minerais opacos }\end{array}$ & $\begin{array}{l}\text { Inequigranular hipidiomórfica, } \\
\text { porfiroclástica; matriz média e } \\
\text { macrocristal grosso. }\end{array}$ & Harzburgito \\
\hline In1/17 & $1,5 \mathrm{~cm}$ & Elipsoidal & $\begin{array}{l}\text { Cinza esverdeado } \\
\text { escuro }\end{array}$ & Maciça & Ortopiroxênio & & Megacristal \\
\hline In1/18 & $2 \mathrm{~cm}$ & Elipsoidal & Verde escuro & Maciça & Ortopiroxênio + olivina & $\begin{array}{c}\text { Granular hipidiomórfica, grossa; } \\
\text { grossa }\end{array}$ & Harzburgito \\
\hline In1/19a & $7 \mathrm{~cm}$ & $\begin{array}{l}\text { Tabular com } \\
\text { bordas lobadas }\end{array}$ & Verde claro & Maciça & $\begin{array}{l}\text { Macrocristais de olivina e carbonato } \\
\text { em matriz não identificada }\end{array}$ & $\begin{array}{c}\text { Inequigranular seriada; matriz } \\
\text { muito fina }\end{array}$ & Autólito \\
\hline In1/19b & $3,5 \mathrm{~cm}$ & $\begin{array}{l}\text { Tabular com } \\
\text { bordas lobadas }\end{array}$ & Verde claro & Maciça & $\begin{array}{l}\text { Macrocristais de olivina e carbonato } \\
\text { em matriz não identificada }\end{array}$ & $\begin{array}{l}\text { Inequigranular seriada; matriz } \\
\text { muito fina }\end{array}$ & Autólito \\
\hline In1/20a & $3,5 \mathrm{~cm}$ & Forma de gota & Verde oliva & Maciça & Olivina & Kink bands & Megacristal \\
\hline In1/20b & $10 \mathrm{~cm}$ & Circular & Cinza esverdeado & Maciça & $\begin{array}{l}\text { Olivina + ortopiroxênio + } \\
\text { clinopiroxênio + flogopita }\end{array}$ & $\begin{array}{l}\text { Granular xenomórfica, grossa; } \\
\text { média a grossa }\end{array}$ & Harzburgito \\
\hline In1/20c & $2,4 \mathrm{~cm}$ & Tabular & Cinza esverdeado & $\begin{array}{l}\text { Foliação definida pelo } \\
\text { Opx e opacos }\end{array}$ & $\begin{array}{l}\text { Olivina + ortopiroxênio + } \\
\text { clinopiroxênio + espinélio }\end{array}$ & $\begin{array}{l}\text { Granular hipidiomórfica, } \\
\text { porfiroclástica; média a fina }\end{array}$ & Harzburgito \\
\hline In1/20d & $2 \mathrm{~cm}$ & Elipse & Branco & Maciça & Quartzo + feldspato (alterado) & Equigranular; fina & Granito \\
\hline In1/20e & $3 \mathrm{~cm}$ & Elipse alongada & Cinza esverdeado & $\begin{array}{l}\text { Foliação definida } \\
\text { pelos opacos }\end{array}$ & $\begin{array}{l}\text { Olivina + ortopiroxênio + } \\
\text { clinopiroxênio + espinélio }\end{array}$ & $\begin{array}{l}\text { Granular hipidiomórfica, } \\
\text { granoblástica; média a fina }\end{array}$ & Lherzolito \\
\hline In1/20f & $0,7 \mathrm{~cm}$ & $\begin{array}{l}\text { Quadrado } \\
\text { arredondado }\end{array}$ & Verde esmeralda & Maciça & Clinopiroxênio & & Macrocristal \\
\hline In1/20g & $1,8 \mathrm{~cm}$ & $\begin{array}{l}\text { Circular, com } \\
\text { borda lobada }\end{array}$ & Verde & Maciça & $\begin{array}{l}\text { Olivina + ortopiroxênio + } \\
\text { clinopiroxênio + espinélio }\end{array}$ & $\begin{array}{c}\text { Granular xenomórfica, grossa; } \\
\text { média }\end{array}$ & Lherzolito \\
\hline In1/20h & $1,3 \mathrm{~cm}$ & Elíptico & Verde & Maciça & $\begin{array}{l}\text { Olivina + ortopiroxênio + } \\
\text { clinopiroxênio + espinélio }\end{array}$ & $\begin{array}{l}\text { Granular xenomórfico, grossa; } \\
\text { media a fina }\end{array}$ & Harzburgito \\
\hline In1/20i & $2 \mathrm{~cm}$ & Tabular & Cinza escuro & Maciça & $\begin{array}{l}\text { Olivina + ortopiroxênio + } \\
\text { clinopiroxênio + flogopita }\end{array}$ & $\begin{array}{l}\text { Granular hipidiomórfica, } \\
\text { granoblástica; média a fina }\end{array}$ & Harzburgito \\
\hline In1/20j & $4,5 \mathrm{~cm}$ & Amebóide & Verde claro & Maciça & $\begin{array}{l}\text { Macrocristais de olivina e carbonato } \\
\text { em matriz não identificada }\end{array}$ & $\begin{array}{l}\text { Inequigranular seriada; matriz } \\
\text { muito fina }\end{array}$ & $\begin{array}{l}\text { Autólito } \\
\text { amebóide }\end{array}$ \\
\hline In1/20I & $2,1 \mathrm{~cm}$ & Circular & $\begin{array}{l}\text { Verde claro com } \\
\text { clasto róseo incluso }\end{array}$ & Maciça & $\begin{array}{l}\text { Macrocristais de olivina e carbonato } \\
\text { em matriz não identificada }\end{array}$ & $\begin{array}{l}\text { Equigranular; fina (autólito) e } \\
\text { média (carbonato) }\end{array}$ & $\begin{array}{l}\text { Autólito com } \\
\text { clasto de } \\
\text { carbonato }\end{array}$ \\
\hline In1/21a & $1 \mathrm{~cm}$ & $\begin{array}{l}\text { Elíptico, } \\
\text { Arredondado }\end{array}$ & Preto & Maciça & Ortopiroxênio & & Megacristal \\
\hline In1/21b & $0,5 \mathrm{~cm}$ & Circular & Preto & Maciça & Flogopita & & Macrocristal \\
\hline
\end{tabular}

Observação: os termos em negrito do item "Texturas e granulação" correspondem aos termos da classificação de Harte (1977). 
Tabela 4 - Continuação.

\begin{tabular}{|c|c|c|c|c|c|c|c|}
\hline $\begin{array}{c}\text { Código da } \\
\text { amostra }\end{array}$ & $\begin{array}{l}\text { Dimensão } \\
\text { máxima }\end{array}$ & Forma & Cor & Estrutura & Composição Mineralógica & Textura e granulação & Natureza \\
\hline In1/22a & $1,8 \mathrm{~cm}$ & $\begin{array}{c}\text { Tabular } \\
\text { arredondado }\end{array}$ & Verde pálido & Maciça & Olivina + ortopiroxênio + mica & $\begin{array}{c}\text { Granular xenomórfico, grossa; } \\
\text { grossa }\end{array}$ & Dunito \\
\hline In1/22b & $1,3 \mathrm{~cm}$ & $\begin{array}{l}\text { Tabular } \\
\text { arredondado }\end{array}$ & Verde pálido & Maciça & Olivina + ortopiroxênio + mica & $\begin{array}{c}\text { Granular xenomórfico, grossa; } \\
\text { media }\end{array}$ & Dunito \\
\hline In1/23a & $1,5 \mathrm{~cm}$ & Anguloso & $\begin{array}{l}\text { Cinza } \\
\text { esverdeado } \\
\text { escuro }\end{array}$ & Maciça & Olivina + ortopiroxênio & $\begin{array}{l}\text { Granular hipidiomórfica, } \\
\text { granoblástica; média a fina }\end{array}$ & Harzburgito \\
\hline In1/23b & $1,3 \mathrm{~cm}$ & Circular & $\begin{array}{l}\text { Verde pálido } \\
\text { (alterado) }\end{array}$ & Maciça & $\begin{array}{c}\text { Olivina + ortopiroxênio + clinopiroxênio + } \\
\text { espinélio }\end{array}$ & $\begin{array}{l}\text { Granular xenomórfica, grossa; } \\
\text { média a fina }\end{array}$ & Lherzolito \\
\hline In1/23c & $3 \mathrm{~cm}$ & Tabular anguloso & $\begin{array}{l}\text { Verde pálido } \\
\text { (alterado) }\end{array}$ & Maciça & $\begin{array}{l}\text { Olivina }+ \text { ortopiroxênio + clinopiroxênio + } \\
\text { espinélio }\end{array}$ & $\begin{array}{l}\text { Granular hipidiomórfica, } \\
\text { granoblástica; média }\end{array}$ & Harzburgito \\
\hline In1/23d & $1,5 \mathrm{~cm}$ & Elíptico & $\begin{array}{l}\text { Verde } \\
\text { acinzentado } \\
\text { claro }\end{array}$ & Maciça & $\begin{array}{c}\text { Olivina + ortopiroxênio + clinopiroxênio + } \\
\text { espinélio }\end{array}$ & $\begin{array}{l}\text { Granular hipidiomórfica, } \\
\text { granoblástica; média a fina }\end{array}$ & Lherzolito \\
\hline In1/24a & $4 \mathrm{~cm}$ & Circular & Cinza & $\begin{array}{l}\text { Leve foliação } \\
\text { definida pelos } \\
\text { opacos }\end{array}$ & $\begin{array}{c}\text { Olivina }+ \text { ortopiroxênio }+ \text { minerais opacos }+ \\
\text { anfibólio }\end{array}$ & $\begin{array}{l}\text { Granular hipidiomórfica, } \\
\text { granoblástica; média a fina }\end{array}$ & Dunito \\
\hline In1/24b & $2 \mathrm{~cm}$ & $\begin{array}{l}\text { Triangular } \\
\text { arredondado }\end{array}$ & Preto & Maciça & $\begin{array}{c}\text { Flogopita }+ \text { minerais opacos }+ \text { ortopiroxênio } \\
+ \text { olivina }\end{array}$ & Inequigranular; média a fina & Mica piroxenito \\
\hline In1/25 & $4 \mathrm{~cm}$ & Tabular & Cinza escuro & Maciça & Ortopiroxênio & & Megacristal \\
\hline In1/26 & $3 \mathrm{~cm}$ & Elipsóide & $\begin{array}{l}\text { Cinza } \\
\text { esverdeado }\end{array}$ & $\begin{array}{l}\text { Leve foliação } \\
\text { dada pelo opx }\end{array}$ & $\begin{array}{c}\text { Olivina }+ \text { ortopiroxênio }+ \text { clinopiroxênio + } \\
\text { espinélio }\end{array}$ & $\begin{array}{l}\text { Inequigranular hipidiomórfica, } \\
\text { porfiroclástica; matriz média e } \\
\text { macrocristais grossos }\end{array}$ & Lherzolito \\
\hline In1/27a & $2 \mathrm{~cm}$ & Elipsóide & Verde & Maciça & Quartzo + feldspato (alterado) & Granular hipidiomórfica; média & Granito \\
\hline In1/27b & $2 \mathrm{~cm}$ & Tabular alongado & $\begin{array}{l}\text { Cinza } \\
\text { esverdeado }\end{array}$ & Maciça & $\begin{array}{l}\text { Olivina + ortopiroxênio + clinopiroxênio + } \\
\text { espinélio }\end{array}$ & $\begin{array}{l}\text { Granular hipidiomórfica, } \\
\text { granoblástica; média }\end{array}$ & Lherzolito \\
\hline In1/28 & $1,5 \mathrm{~cm}$ & Elipsóide & $\begin{array}{l}\text { Cinza } \\
\text { esverdeado }\end{array}$ & Maciça & $\begin{array}{c}\text { Olivina }+ \text { ortopiroxênio }+ \text { clinopiroxênio }+ \\
\text { espinélio }\end{array}$ & $\begin{array}{l}\text { Granular hipidiomórfica, } \\
\text { granoblástica; média a fina }\end{array}$ & Lherzolito \\
\hline In1/29 & $1,5 \mathrm{~cm}$ & Elipsóide & $\begin{array}{l}\text { Cinza } \\
\text { esverdeado }\end{array}$ & Maciça & $\begin{array}{l}\text { Olivina }+ \text { ortopiroxênio + clinopiroxênio + } \\
\text { espinélio }\end{array}$ & $\begin{array}{l}\text { Granular xenomórfica, grossa; } \\
\text { média a fina }\end{array}$ & Lherzolito \\
\hline In1/30 & $3,5 \mathrm{~cm}$ & Circular & Verde & Maciça & $\begin{array}{c}\text { Macrocristais de olivina e carbonato em } \\
\text { matriz não identificada }\end{array}$ & $\begin{array}{l}\text { Inequigranular; matriz muito } \\
\text { fina }\end{array}$ & Autólito \\
\hline In1/31 & $2 \mathrm{~cm}$ & Elipsóide & $\begin{array}{l}\text { Cinza róseo } \\
\text { escuro }\end{array}$ & Maciça & $\begin{array}{l}\text { Flogopita + minerais opacos }+ \text { ortopiroxênio } \\
+ \text { olivina }+ \text { clinopiroxênio }\end{array}$ & Inequigranular; média a fina & Mica peridotito \\
\hline In1/32 & $2 \mathrm{~cm}$ & Tabular elipsóidal & $\begin{array}{c}\text { Verde } \\
\text { acinzentado }\end{array}$ & Maciça & $\begin{array}{l}\text { Olivina + ortopiroxênio + clinopiroxênio + } \\
\text { espinélio }\end{array}$ & $\begin{array}{c}\text { Granular xenomórfico, grossa; } \\
\text { média a grossa }\end{array}$ & Lherzolito \\
\hline
\end{tabular}

Observação: os termos em negrito do item "Texturas e granulação" correspondem aos termos da classificação de Harte (1977). 


\subsection{Harzburgitos}

O nome desta rocha foi originado devido a uma importante ocorrência situada nas montanhas Harz na Alemanha.

Os harzburgitos correspondem ao litotipo mais abundante entre os xenólitos do Kimberlito Indaiá, apresentam diferentes granulometrias e texturas, além de conterem espinélio, ou flogopita, e clinopiroxênio em quantidades variadas. Podem ser divididos em 5 tipos principais:

- Com espinélio e textura grossa tabular;

- Com cromita e textura granoblástica;

- De textura grossa e olivina muito fina na borda dos cristais grossos;

- De textura grossa e bolsões de flogopita;

○ De textura grossa, com bolsões e veios de clinopiroxênio.

\subsubsection{Harzburgito com espinélio e textura grossa tabular}

As espécies com granulação grossa e espinélios castanho avermelhados correspondem aos harzburgitos mais freqüentes, sendo representadas pelas seções de códigos In1/9 (Figura 8) e In1/13b. Contêm clinopiroxênio ( 2 a 3,6\%), porém não o suficiente para serem classificados como lherzolitos (Figura 5). A granulometria deste tipo varia de 1 a 7,3 $\mathrm{mm}$ nas olivinas, que são anedrais a subédricas; 1 a 14,7 mm nos ortopiroxênios, também com forma anedral a subédrica; 0,5 a 3,7 mm no clinopiroxênio, com forma euédrica a subédrica; e 0,3 a 3,8 mm em espinélios (cerca de 3\% nas amostras), com aspecto intersticial. Os contatos entre os grãos são em sua maioria irregulares, apesar de ocorrerem escassos setores onde os contatos entre os grãos formam ângulos de $120^{\circ}$. Ocorre extinção kinked bands em diversos cristais de olivina e ortopiroxênio.

A textura desta rocha assemelha-se à descrita como protogranular por Mercier \& Nicolas (1975) ou grossa (Harte 1977), já que ocorre pouca deformação, evidenciada apenas pela presença de kinked bands. Alguns cristais de ortopiroxênio têm inclusões arredondadas de olivina. O clinopiroxênio ocorre em inclusões no ortopiroxênio e em contato com ortopiroxênio e olivina. O espinélio apresenta forma intersticial, porém inclusões finas de espinélio 

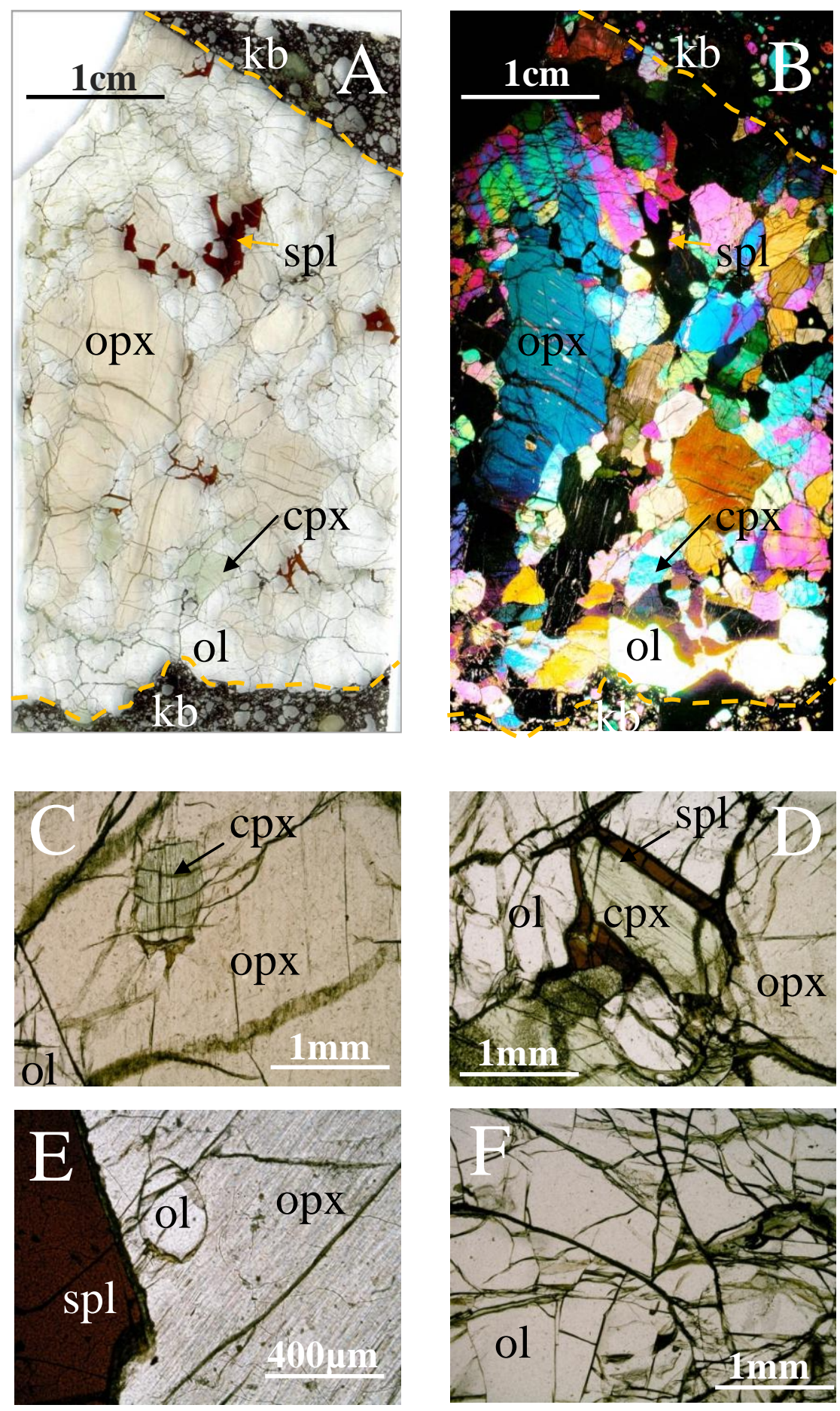

Figura 8- Seção In1/9 representando harzburgito contendo espinélio castanho avermelhado e com textura grossa tabular. A) Imagem de scanner mostrando a seção delgada em sua totalidade; B) Imagem de seção delgada obtida pela montagem de micrografia obtida em microscópio com polarizadores cruzados; C) Inclusão de clinopiroxênio em ortopiroxênio, além de pequenas inclusões de espinélios; D) Espinélio intersticial bordejando cristal de clinopiroxênio; E) Espinélio + ortopiroxênio com inclusão de olivina; e F) Padrão de fraturamento da olivina nesta seção. Legenda: ol-olivina, cpx-clinopiroxênio, opx-ortopiroxênio, spl-espinélio. 
ocorrem no interior do ortopiroxênio; inclusões similares foram identificadas em ortopiroxênios de espinélio lherzolitos do Kimberlito sulafricano Premier (Grégoire et al. 2005). A presença de cristais grandes pode ser explicada pela grande quantidade de voláteis no sistema, como ocorre no caso dos pegmatitos (Dawson, 1980).

\subsubsection{Harzburgito com cromita e textura granoblástica}

Os harzburgitos com granulação média a fina, com textura granular hipidiomórfica, também muito freqüentes, são representados pela seção de código In1/3 (Figura 9). São muito pobres em clinopiroxênio (1\%), e apresentam cromita $(2,3 \%)$ de coloração preta com forma subédrica disposta entre os grãos de olivina e ortopiroxênio. A granulometria varia de 0,75 a 3 $\mathrm{mm}$ nas olivinas, principalmente subédricas, com algumas poucas anedrais; 0,2 a 4,25 mm nos ortopiroxênios, também com forma subédrica a anedral; 0,5 a $1 \mathrm{~mm}$ no clinopiroxênio, com forma subédrica a euedral, associada à cromita e ao ortopiroxênio; e 0,1 a $1 \mathrm{~mm}$ em cromitas, com forma subédrica ou euédrica. São comuns contatos entre os grãos de $120^{\circ}$; além disso os cristais maiores apresentam kinked bands.

Esta rocha apresenta indícios de recristalização por deformação no manto. O formato predominantemente subidiomófico das olivinas e a orientação preferencial dos cristais de cromita sugerem que a rocha sofreu deformação; além disso, os cristais de ortopiroxênio, maiores, apresentam kink bands características de deformação, sugerindo uma textura predominantemente granoblástica com alguns pouco relictos da textura porfiroclástica (Mercier \& Nicolas 1975, Harte 1977). A presença de cromita ao invés de espinélio indica que a rocha é empobrecida em alumínio, o que também é indicado pela pouca quantidade de clinopiroxênio, que é restrita às proximidades dos grãos de cromita.

3.6.3. Harzburgito de textura grossa, com cristais pequenos de olivina recristalizada na borda de cristais maiores

Apresenta granulação grossa, olivina em cristais muito pequenos recristalizada na borda dos cristais maiores de olivina, e é representado pela amostra In1/1 (Figura 10). Sua textura é granular xenomórfica, predominantemente. Clinopiroxênio é ausente, assim 

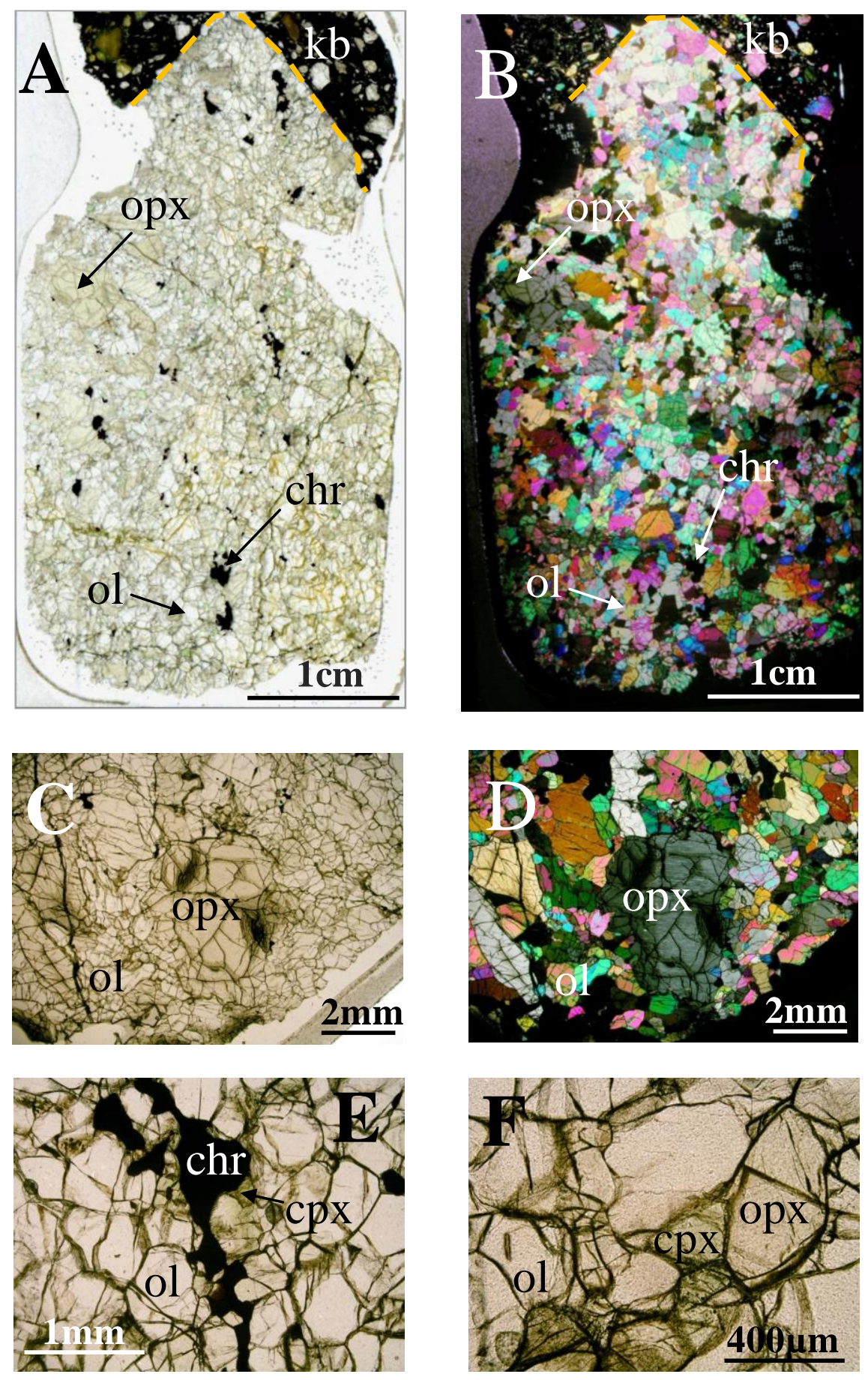

Figura 9- Seção In1/3 de harzburgito com cromita e textura granoblástica. A) Imagem de scanner mostrando a seção delgada em sua totalidade; B) Imagem de seção delgada obtida pela montagem de micrografia obtida em microscópio com polarizadores cruzados; C) Macrocristal de ortopiroxênio em meio a cristais menores de olivina, ortopiroxênio e espinélio; D) Mesma porção mostrada na imagem anterior com polarizadores cruzados mostrando kinked bands no ortopiroxênio; E) Cromita entre os grãos de olivina; F) Clinopiroxênio em contato com olivina e ortopiroxênio. Legenda: chr-cromita, kb-kimberlito. 

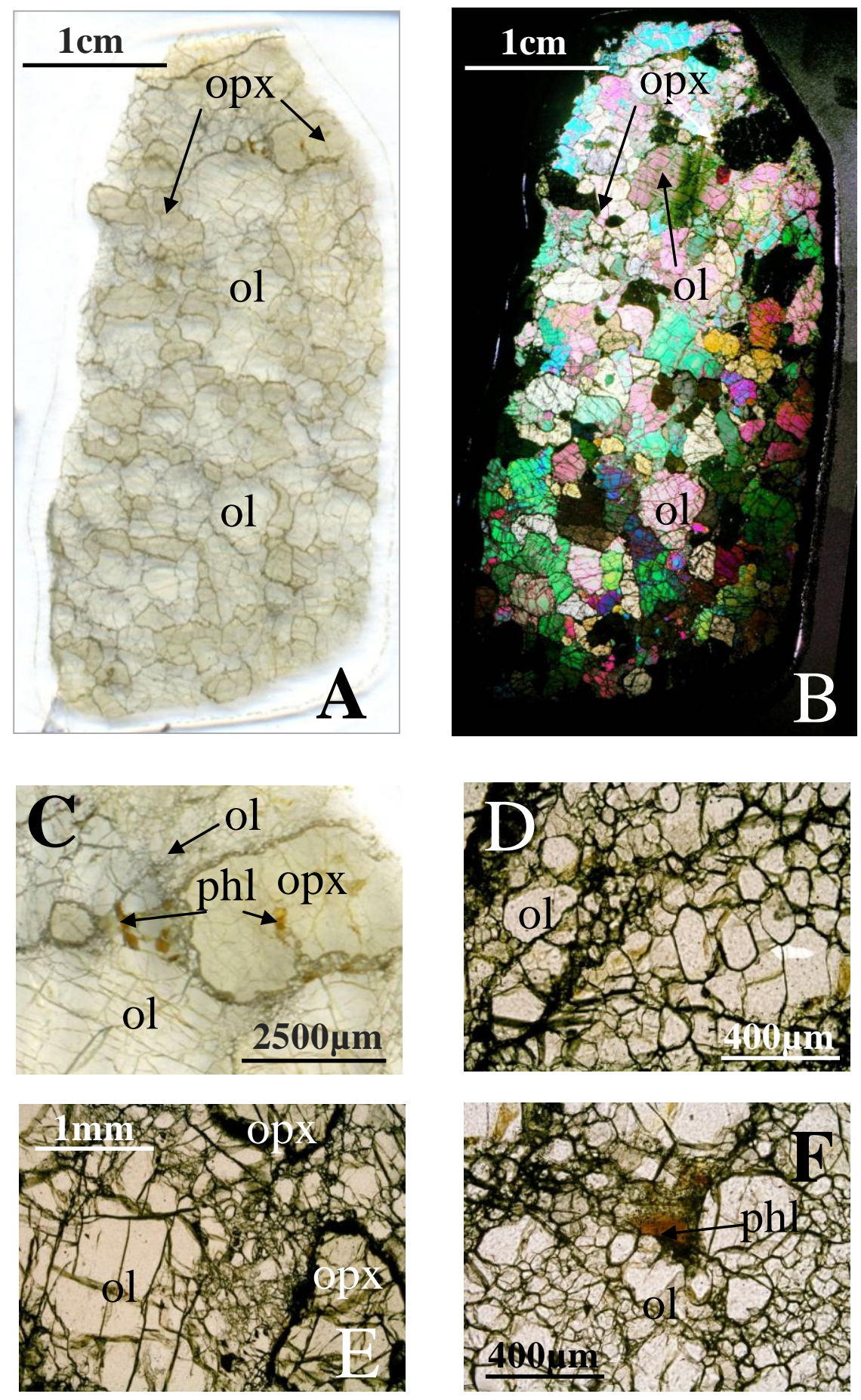

Figura 10- Seção In1/1 representando harzburgito de granulação grossa, com macrocristais de olivina recristalizados nas bordas dos cristais maiores. A) Imagem de scanner mostrando a seção delgada em sua totalidade; B) Imagem de seção delgada obtida pela montagem de micrografia obtida em microscópio com polarizadores cruzados; C) Cristal de ortopiroxênio com flogopita infiltrada em suas fraturas e borda; D) Olivina recristalizada na borda dos macrocristais de olivina; E) Contato entre olivina e ortopiroxênio; e F) Flogopita entre os grãos recristalizados de olivina. Legenda: phl-flogopita. 
como os minerais opacos como espinélio e cromita. Ocorre flogopita associada às porções recristalizadas da rocha. A granulometria varia de 4 a 6,8 $\mathrm{mm}$ nas olivinas maiores, anédricas, e em torno de $0,5 \mathrm{~mm}$ nas porções recristalizadas, com forma de seção hexagonal; em torno de 3,5 mm no ortopiroxênio, que apresenta forma anedral; a flogopita ocorre intersticial e muito fina, de 0,05 a $0,25 \mathrm{~mm}$. O contato entre os grãos é irregular, e é comum extinção ondulosa ou kinked bands nos cristais maiores.

A ausência de clinopiroxênio nesta rocha indica que a mesma é empobrecida, ou por ser resíduo de uma fusão parcial ou por ser um cumulato de olivina e ortopiroxênio. A rocha apresenta textura grossa, porém a presença de setores onde ocorre olivina recristalizada muito fina pode indicar um processo de transição para a textura porfiroclástica (Mercier \& Nicolas 1975, Harte 1977), ou pode ter ocorrido recristalização por injeção de fluidos metassomáticos, já que associada aos microcristais idiomórficos em mosaico ocorre flogopita intersticial. Outra sugestão para esta recristalização da olivina e injeção de flogopita no sistema seria a interação do magma kimberlítico com o xenólito.

Tanto para esta amostra quanto para os outros peridotitos com cromita estudados não foram identificadas as feições de intercrescimento cromita-silicato descritas por Dawson \& Smith (1975) em xenólitos contendo espinélio de kimberlitos sul-africanos.

\subsubsection{Harzburgito de textura grossa e bolsões de flogopita}

Ocorre também um tipo de xenólito com granulação grossa a média com bolsões de flogopita $(6,3 \%)$ associados com cromita (1\%), que corresponde à seção de código In1/20b (Figura 11). A granulometria varia de 1 a $6,25 \mathrm{~mm}$ nas olivinas, que são anédricas; em torno de 3,0 mm no ortopiroxênio, que apresenta forma anedral. Clinopiroxênio é ausente. A flogopita ocorre em bolsões dispostos entre os grãos de olivina e ortopiroxênio, ou em pequenos veios, que têm dimensões que variam de 0,1 a 1,25 mm, formando agregados. Ocorrem cromita, ilmenita e outros minerais opacos no centro destes agregados. Os contatos entre a olivina e o ortopiroxênio são irregulares e ocorre extinção ondulante nos cristais de olivina maiores.

Esta rocha tem típica textura grossa (Harte, 1977), onde ortopiroxênio e olivina parecem

ser contemporâneos. É possível estabelecer que os bolsões de flogopita contendo minerais opacos são tardios e provavelmente são resultado de um processo de metassomatismo mantélico. Nas 
porções onde ocorrem bolsões de flogopita, a rocha é mais fraturada e com maior quantidade de olivina fina recristalizada.

\subsubsection{Harzburgito de textura grossa, com bolsões de clinopiroxênio}

A seção de código I1/12 (Figura 12) apresenta um tipo de granulação média a grossa e textura granular xenomórfica com clinopiroxênio intersticial de cor verde esmeralda (2,6\%). A granulometria varia de 1 a 5,5 mm nas olivinas, que são anédricas; de 1 a 3 mm no ortopiroxênio, que apresenta forma anedral a subédrica; e de 0,4 a 1,8 mm no clinopiroxênio. Há quantidades muito pequenas de flogopita e minerais opacos inclusos no clinopiroxênio. Os contatos entre a olivina e o ortopiroxênio são irregulares e a extinção ondulante predomina nos cristais de olivina.

A textura da rocha é do tipo grossa, sem nenhuma evidência de deformação. Os cristais grandes de olivina e ortopiroxênio parecem ter sido desenvolvidos contemporaneamente. Não há deformação ou indício de textura metamórfica, podendo corresponder à classificação de Pike \& Scharzman (1977) de textura ígnea. O clinopiroxênio é um mineral tardio, que provavelmente foi gerado por metassomatismo. Este mineral reagiu com os minerais hospedeiros e provocou um desequilíbrio das fases, principalmente de ortopiroxênio, que foi parcialmente consumido, deixando um aspecto pulverulento em alguns setores dos bolsões. 

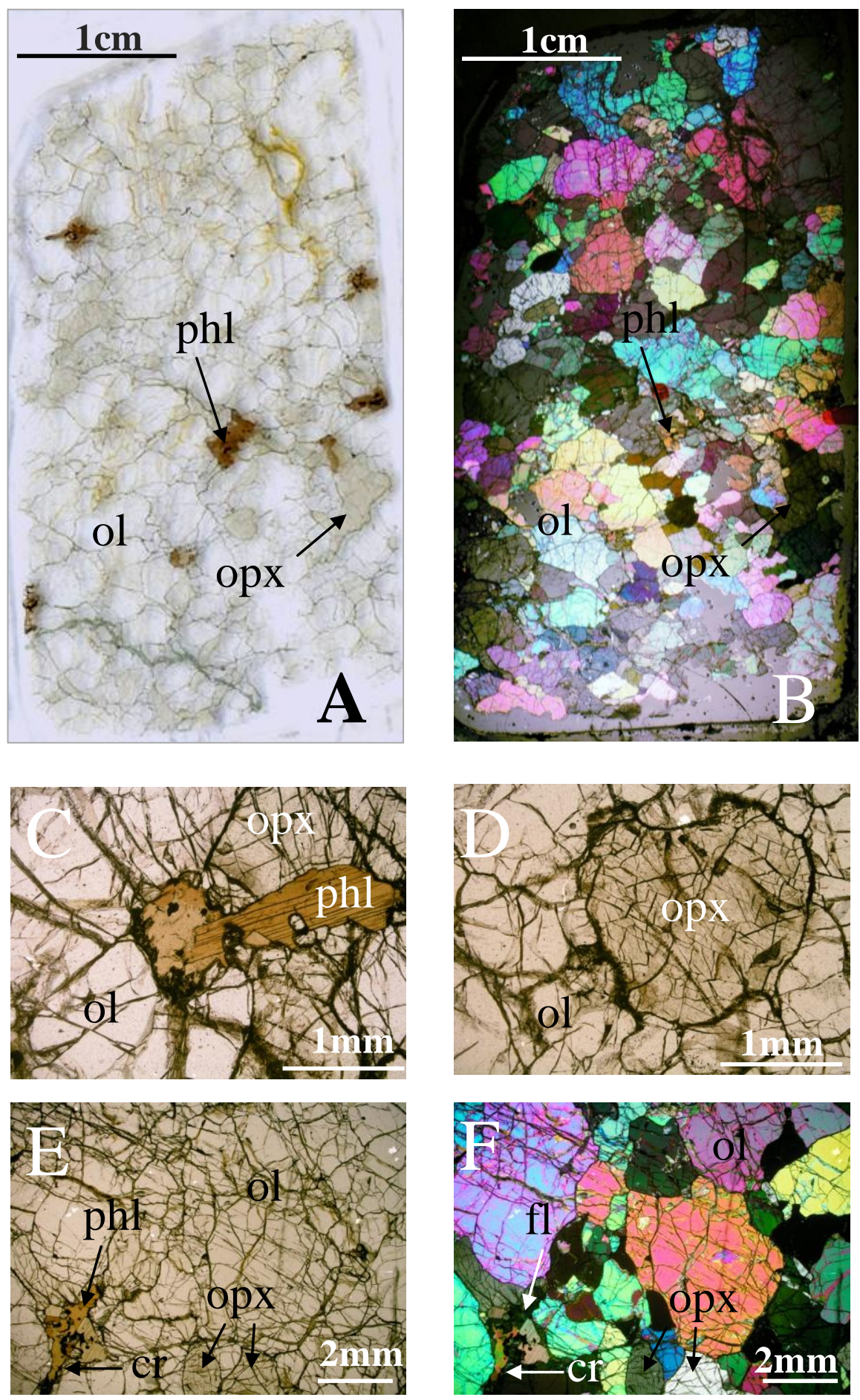

Figura 11- Seção In1/20b representando harzburgito de textura grossa e bolsões de flogopita associados com cromita. A) Imagem de scanner mostrando a seção delgada em sua totalidade; B) Imagem de seção delgada obtida pela montagem de micrografia obtida em microscópio com polarizadores cruzados; C) Flogopita entre os grãos de olivina; D) Ortopiroxênio anedral em contato com olivina; E) Porção exibindo hábito anedral dos minerais e flogopita intersticial associada com opacos; F) Mesma imagem exibida na figura E com polarizadores cruzados. 

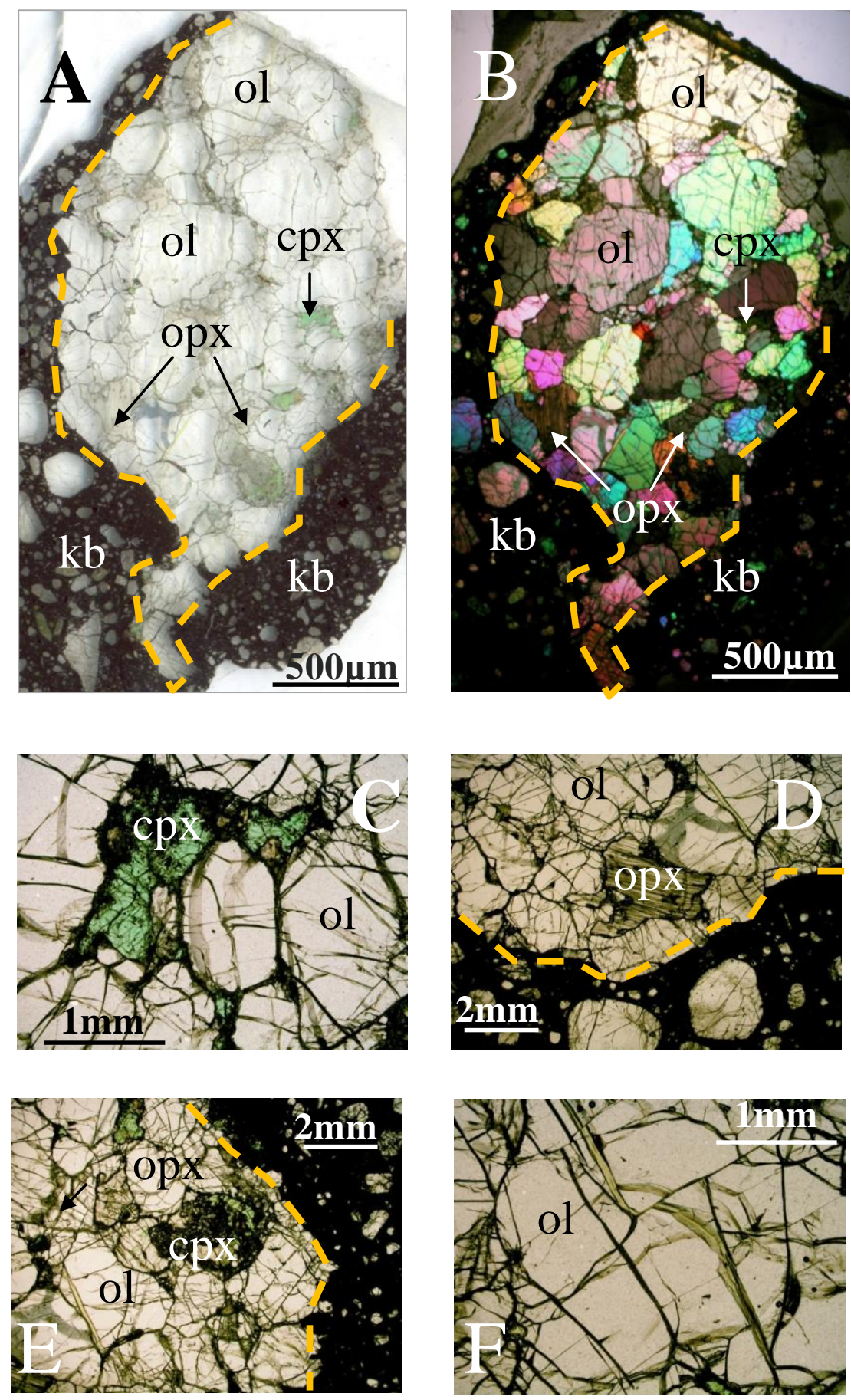

Figura 12- Seção In1/12 representando harzburgito de textura grossa, com veios e bolsões de clinopiroxênio. A) Imagem de scanner mostrando a seção delgada em sua totalidade; B) Imagem de seção delgada obtida pela montagem de micrografia obtida em microscópio com polarizadores cruzados; C) Clinopiroxênio intersticial na olivina idiomórfica; D) Ortopiroxênio com lamelas de clinopiroxênio; E) Porções ricas em clinopiroxênio com flogopita, onde há intensa corrosão dos minerais pré existentes; e F) Padrão de fraturamento da olivina. 


\subsection{Lherzolitos}

$\mathrm{O}$ termo lherzolito se originou devido às ocorrências deste tipo de rocha nos Complexos Peridotíticos Alpinos na França, na região de Etang de Lers, nos Pirineus Franceses. A palavra "Lherz" é a pronúncia arcaica utilizada nesta região.

Os lherzolitos, também bastante abundantes na intrusão Indaiá, contêm espinélio castanho avermelhado geralmente intersticial (cerca de 2\%). Dois tipos principais foram descritos (Figuras 13 e 14).

Exibem matriz fina a média e macrocristais grossos com extinção ondulante ou kinked bands, como na seção In1/4 (Figura 12). A olivina tem forma anedral variando de 0,5 a 4,25 mm (cerca de $60 \%$ na moda), o ortopiroxênio varia de $0,5 \mathrm{~mm}$ (matriz) a $8,25 \mathrm{~mm}$ (megacristais) com $28 \%$ na moda, o clinopiroxênio varia de 0,25 a $7 \mathrm{~mm}$ (12\% na moda); espinélio é intersticial, com 0,3 a $1,4 \mathrm{~mm}$.

A textura porfiroclástica (Harte, 1977) foi identificada devido à presença de grãos maiores apresentando extinção kinked band e pela matriz com forma poligonizada. Alguns minerais parecem ter sofrido processo de recristalização, como o olivina e o clinopiroxênio. $O$ ortopiroxênio, por ser mais resistente à deformação, permaneceu preservado, na forma dos macrocristais que mostram lamelas de exsolução.

\subsubsection{Lherzolito de textura grossa}

Um segundo tipo de lherzolito tem a granulação mais homogênea, variando de média a grossa, como na seção In1/14a (Figura 14). A olivina com forma anedral a subedral tem tamanho que varia de 2 a 5,8 $\mathrm{mm}$ (70\% na moda). O ortopiroxênio varia de 1,3 a 6,4 mm (22\% modal), e o clinopiroxênio de 0,5 a $3,7 \mathrm{~mm}$ (6\% modal). Espinélio ocorre intersticial e em veios, com dimensões de 0,3 a 1,4 mm. Os contatos entre a olivina e o ortopiroxênio formam ângulos de $120^{\circ} \mathrm{em}$ algumas porções destas rochas. Alguns cristais apresentam kinked bands.

Segundo a classificação de Harte (1977) a textura desta rocha é grossa, porém o grande equilíbrio textural entre os grãos indica processo de recristalização, evidenciando um possível início de passagem da textura grossa para uma textura porfiroclástica. Não há indícios de ordem de cristalização, apenas que o espinélio foi o último mineral a cristalizar. 

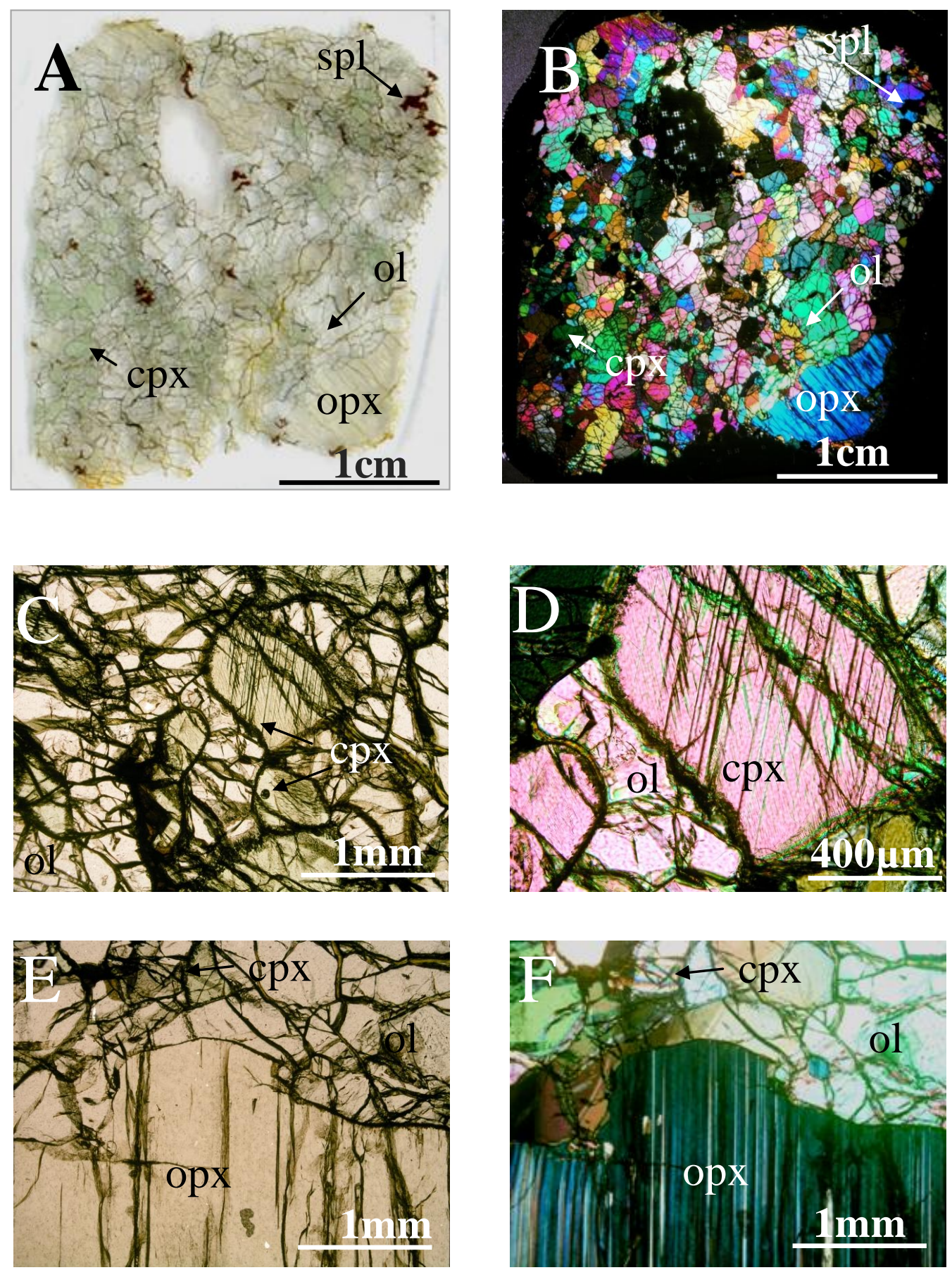

Figura 13- Seção In1/4 representando lherzolito com espinélio castanho avermelhado e textura porfiroclástica. A) Imagem de scanner mostrando a seção delgada em sua totalidade; B) Imagem de seção delgada obtida pela montagem de micrografia obtida em microscópio com polarizadores cruzados; C) Clinopiroxênio entre grãos de olivina e ortopiroxênio; D) Clinopiroxênio da imagem anterior, com clivagens bem marcadas; E) Megacristal de ortopiroxênio em contato com grãos de olivina; e F) Mesma imagem da figura E com polarizadores cruzados. 

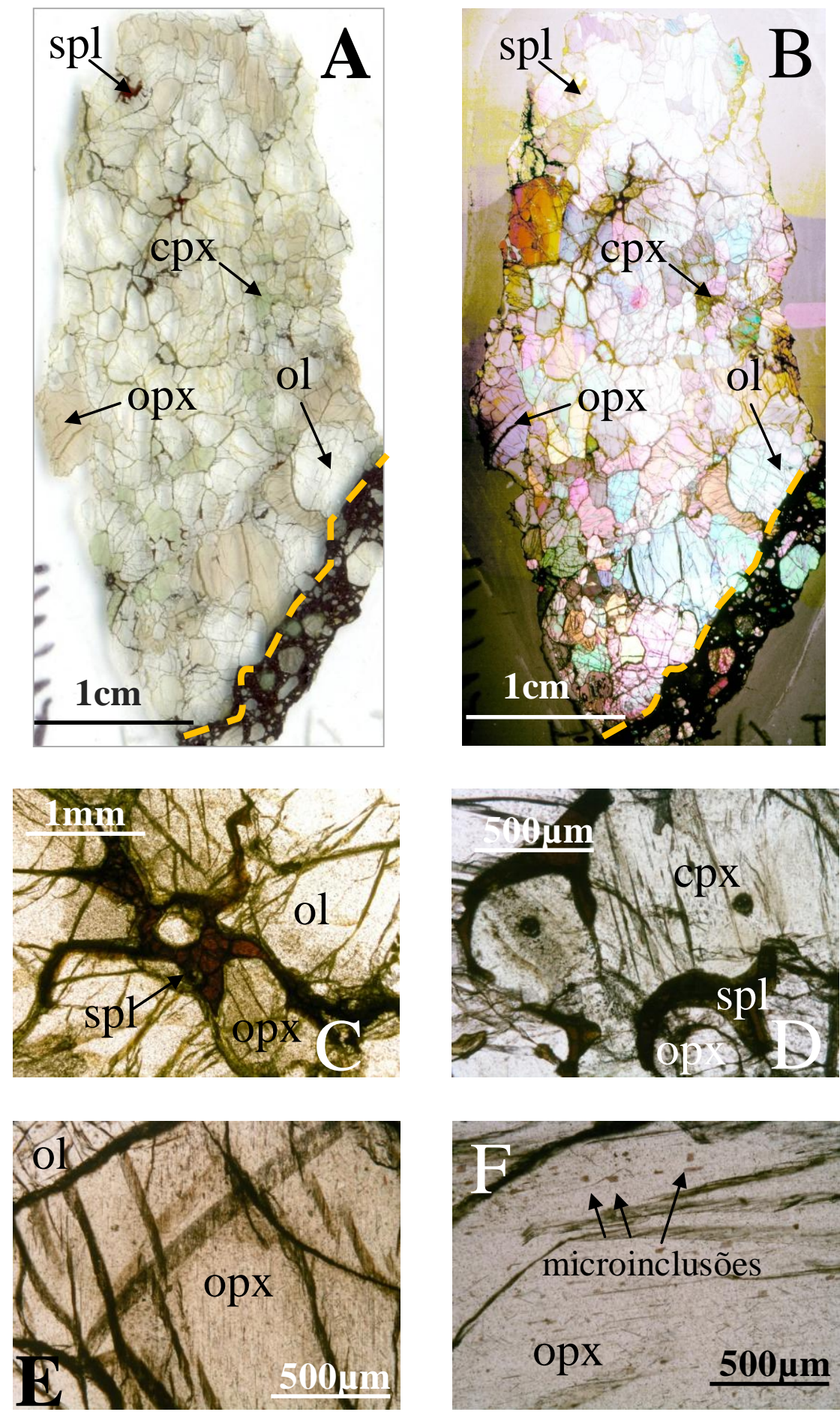

Figura 14- Seção In1/14a representando lherzolito com espinélio castanho avermelhado intersticial e textura grossa. A) Imagem de scanner mostrando a seção delgada em sua totalidade; B) Imagem de seção delgada obtida pela montagem de micrografia obtida em microscópio com polarizadores cruzados; C) Espinélio intersticial em meio a cristais de ortopiroxênio e olivina; D) Espinélio no contato do clinopiroxênio com o ortopiroxênio; E) Padrão de fraturamento do ortopiroxênio que está em contato com olivina; e F) Microinclusões em ortopiroxênio. 


\subsection{Dunitos}

O nome desta rocha foi originado devido a uma importante ocorrência situada na Nova Zelândia, nas montanhas Dun, próximas à cidade de Nelson na Ilha Sul.

As amostras de dunito, a exemplo dos harzburgitos, podem conter espinélio, ou flogopita, e clinopiroxênio. São divididas em dois tipos principais: flogopita dunito e dunito com cromita e textura granoblástica.

\subsubsection{Flogopita dunito de textura grossa}

Este tipo corresponde a uma rocha com granulação grossa a média com bolsões de flogopita associada com cromita, e correspondente à seção In1/2 (Figura 15), semelhante ao último harzburgito da seção In1/20b. A granulação varia de 2 a 7 mm nas olivinas (84\%), que são anédricas e de 0,75 a 2,5 mm no ortopiroxênio (4,5\%), que também apresenta forma anedral. Os contatos entre a olivina e o ortopiroxênio são irregulares. A flogopita (6,3\%) ocorre em bolsões dispostos entre os grãos de olivina e ortopiroxênio, ou em pequenos veios, e tem dimensões que variam de 0,1 a $1,25 \mathrm{~mm}$, formando agregados. Ocorrem minerais opacos no centro destes agregados (Figura 16), cromita, ilmenita, magnetita e perovskita, respectivamente em ordem decrescente de abundância. Cristais de clinopiroxênio associados aos bolsões de flogopita são subédricos a euédricos, com tamanhos que variam de 0,25 a $1 \mathrm{~mm}$.

Segundo a classificação de Harte (1977), o exemplar corresponde a um xenólito com textura grossa, pois são poucos ou ausentes os índicos de recristalização. O metassomatismo pode ser identificado nestas amostras pela presença dos bolsões contendo flogopita e clinopiroxênio intersticial. Cromita e ilmenita são as fases mais comuns no centro dos bolsões, e podem ou não estar em equilíbrio textural, ou seja em contatos retos ou irregulares. Quando os contatos são irregulares, ocorre magnetita na borda da cromita e perovskita na borda da ilmenita, como pode ser observado na Figura 16. 

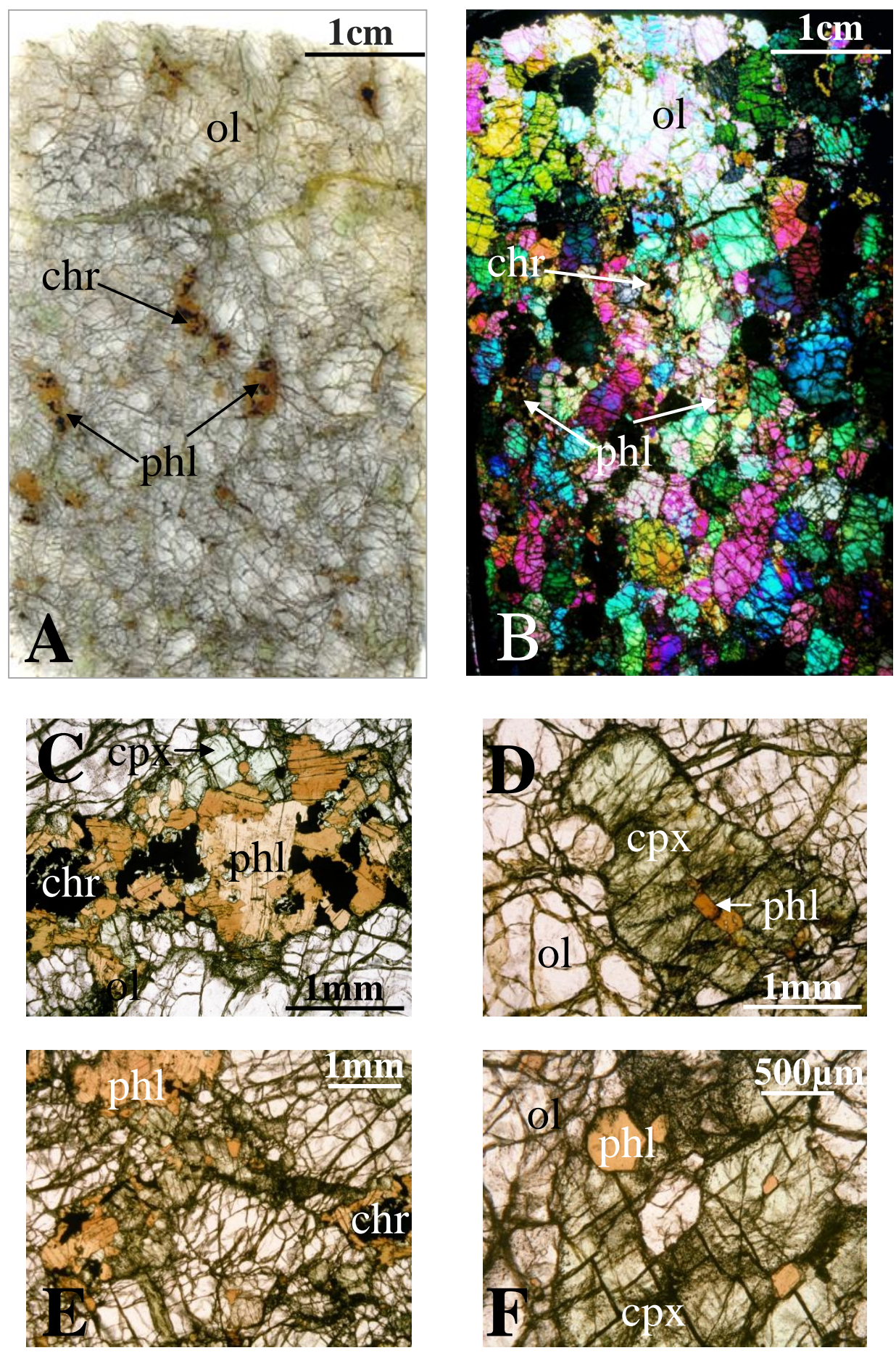

Figura 15- Seção In1/2 representando flogopita dunito de textura grossa. A) Imagem de scanner mostrando a seção delgada em sua totalidade; B) Imagem de seção delgada obtida pela montagem de micrografia obtida em microscópio com polarizadores cruzados; C) Bolsão de flogopita contendo minerais opacos e clinopiroxênio associados; D) Clinopiroxênio anedral com inclusão de flogopita; E) Cristais de olivina fraturados em contato com bolsões de flogopita, clinopiroxênio e opacos; F) Flogopita hexagonal inclusa no clinopiroxênio. 

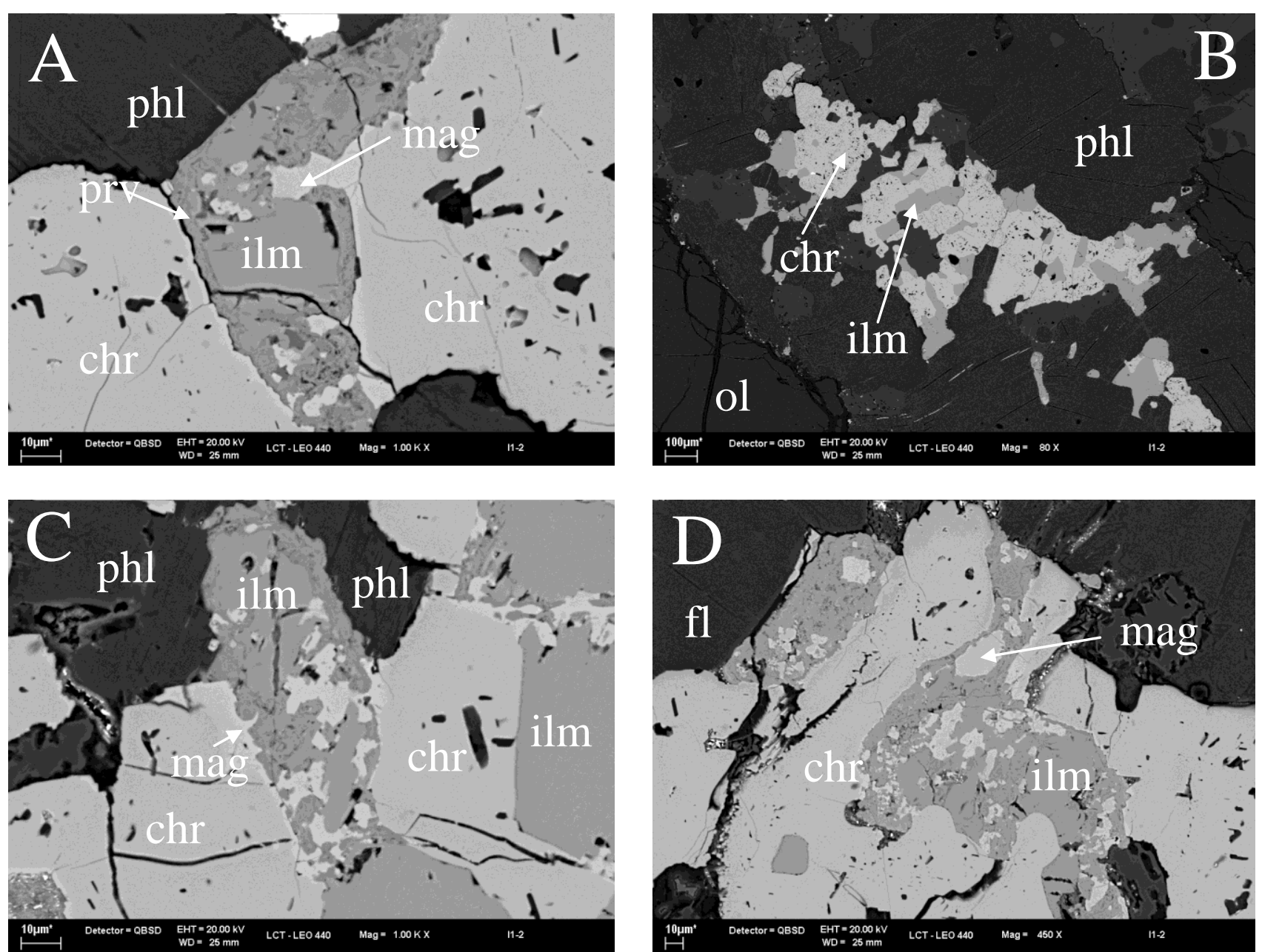

Figura 16- Imagens de microscópio eletrônico de varredura mostrando as texturas entre os diferentes minerais opacos encontrados em meio aos bolsões de flogopita da seção In1/2. A) Cromita em associação com ilmenita; B) Ilmenita e cromita em meio aos cristais de flogopita; C) Associação cromita+ilmenita+magnetita; D) Textura de desequilíbrio entre ilmenita e cromita. Legenda: mag magnetita, prv- perovskita e ilm - ilmenita. 


\subsubsection{Dunito com cromita e textura granoblástica}

Um segundo tipo de dunito apresenta granulação fina a média, cromita (1\%) entre os grãos de olivina e ortopiroxênio e alguns grãos isolados de anfibólio (0,2\%), correspondendo à seção In1/24a (Figura 17). Sua textura é granular hipidiomórfica, assemelhando-se ao harzburgito da amostra In1/3. A granulação varia de 0,5 a $0,9 \mathrm{~mm}$ nas olivinas (90\%), que são subedrais, e de 0,5 a $1,1 \mathrm{~mm}$ no ortopiroxênio $(8,8 \%)$, que também apresenta forma anedral ou subedral. A cromita apresenta forma subédrica a euédrica e cor preto a castanho escuro nas suas bordas. O anfibólio tem suas clivagens bem destacadas e tende a idiomórfico, situando-se entre os grãos de olivina e ortopiroxênio. Os contatos entre os grãos são retos e em algumas regiões estão dispostos a $120^{\circ}$.

Segundo a classificação de Harte (1977) esta rocha apresenta características da textura granoblástica. Ocorreu uma notável recristalização dos minerais, inclusive das cromitas, que apresentam foliação por causa do processo de deformação. Pela mineralogia, esta rocha é empobrecida em elementos como $\mathrm{Al}, \mathrm{Fe}$ e $\mathrm{Ca}$, já que ocorre cromita em lugar de espinélio e não há clinopiroxênio. Portanto é provável que a rocha seja um resíduo de fusão parcial. 

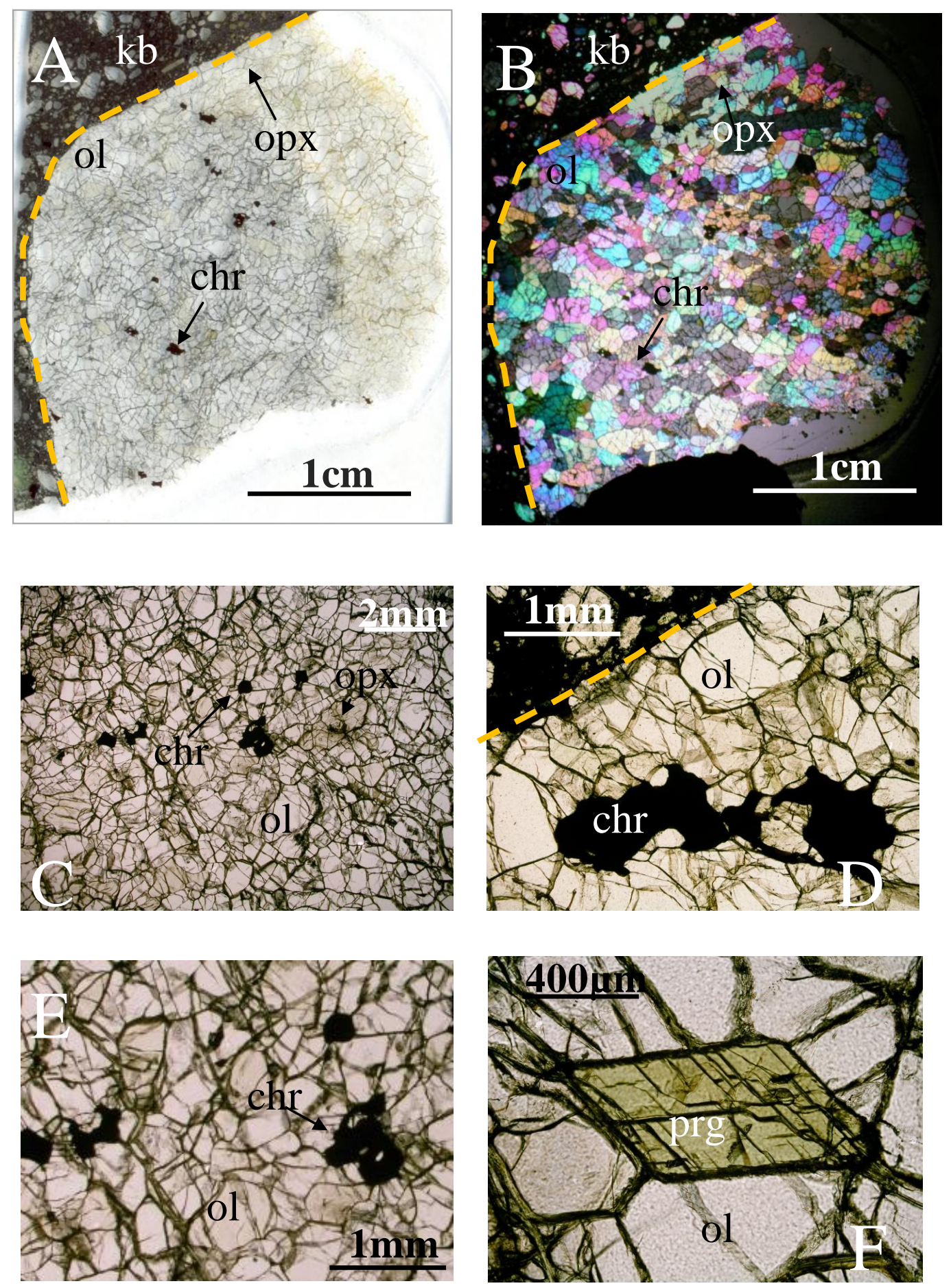

Figura 17- Seção In1/24a representando dunito com cromita e textura granoblástica. A) Imagem de scanner mostrando a seção delgada em sua totalidade; B) Imagem de seção delgada obtida pela montagem de micrografia obtida em microscópio com polarizadores cruzados; C) Grãos de olivina finos com formatos suédrico a euédrico; D) Detalhe da cromita anedral em meio a grãos de olivina com textura granoblástica; E) Hábito anedral da cromita em meio aos grãos de olivina e ortopiroxênio; e F) Grão de anfibólio euedral em meio aos grãos de olivina (pargasita). Legenda: prg-pargasita. 


\subsection{Mica piroxenitos}

Os mica piroxenitos são compostos essencialmente pela associação flogopita+ortopiroxênio+minerais opacos, e estão representados pelas amostras I1/24b (Figura 17) e I1/31 (Figura 18). A flogopita é fase mais abundante nas amostras, com 44 a $67 \%$ da moda, tem coloração marrom avermelhada e tamanho que varia de 0,25 a 2 mm, apresentando contato direto com minerais opacos agregados (Figura 20). Estes por sua vez apresentam formato anedral e são constituídos por cromita, ilmenita, magnetita e perovskita. O mineral opaco predominante é a ilmenita, que se apresenta em reação com cromita, com geração de magnetita e perovskita. Uma textura frequiente é o desequilíbrio entre ilmenita e flogopita ou ortopiroxênio (fases silicáticas), que gera um mineral rico em Si e Ti nas bordas da ilmenita (Figura 19 e detalhes no item 4.9). Este mineral é freqüente nas amostras e pode conter inclusões de magnetita idiomórfica. Em algumas fraturas de ilmenita ocorre perovskita.

O ortopiroxênio tem coloração cinza e tamanho variando de 0,1 a $0,8 \mathrm{~mm}$ e textura poiquilítica, englobando flogopita e ilmenita.

As relações texturais destas rochas revelam que o ortopiroxênio e a olivina são as fases mais antigas, que sofreram corrosão pela passagem dos fluidos metassomáticos. Os minerais opacos sempre ocorrem em forma xenomórfica arredondada, parecendo ser fases mais antiga que a flogopita. Ainda ocorrem inclusões de ilmenita em ortopiroxênio e olivina, indicando que houve dois momentos de cristalização de ortopiroxênio e olivina.

As características mineralógicas destas rochas indicam clara relação com fluidos metassomáticos, sendo possível enquadrar estes como xenólitos das suítes MARID (mica+anfibólio+rutilo+ilmenita+diopsídio) ou PIC (flogopita+ilmenita+clinopiroxênio). A ausência de anfibólio e rutilo nos xenólitos estudados indica uma associação do tipo PIC, porém a química mineral (a ser apresentada no itens 4.5. e 4.6) indica similaridades com a suite MARID. Em estudo na região do Alto Paranaíba, Tallarico (1991) descreve xenólitos com flogopita, ilmenita e richterita nas intrusão Mata do Lenço, que também corresponderiam a exemplares da suite MARID. 

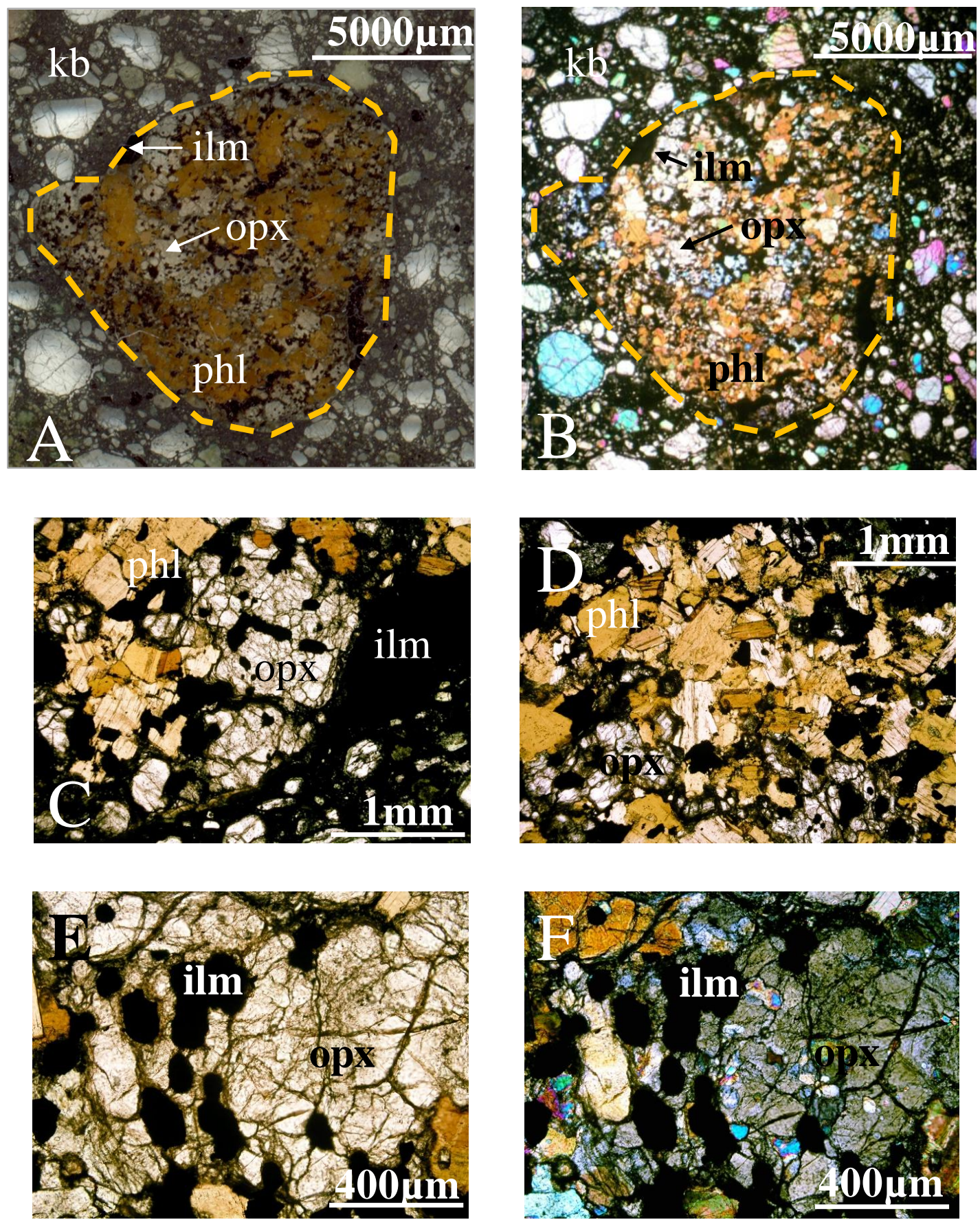

Figura 18- Seção In1/24b representando mica piroxenito. A) Imagem de scanner mostrando a seção delgada em sua totalidade; B) Imagem de seção delgada obtida pela montagem de micrografia obtida em microscópio com polarizadores cruzados; C) Hábito anedral do clinopiroxênio em meio a cristais de ilmenita e flogopita; D) Agregado de flogopita com cristais anedrais de ortopiroxênio e ilmenita; E) Cristais arredondados de ilmenita em meio a cristais de ortopiroxênio; e F) Mesma imagem que a anterior com os polarizadores cruzados. 

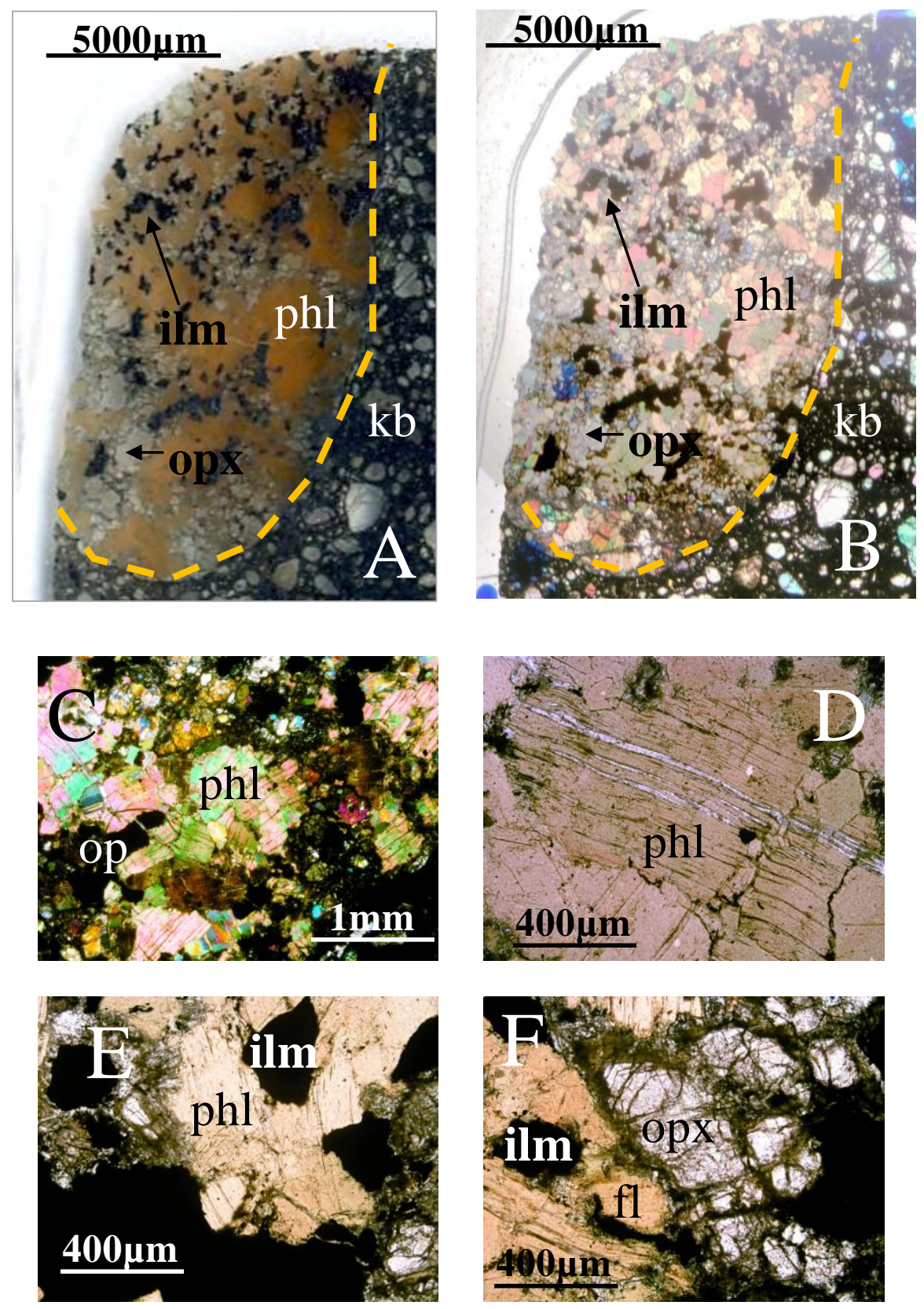

Figura 19- Seção In1/31 representando mica piroxenito. A) Imagem de scanner mostrando a seção delgada em sua totalidade; B) Imagem de seção delgada obtida pela montagem de micrografia obtida em microscópio com polarizadores cruzados; C) Associação entre flogopita, ortopiroxênio e ilmenita; D) Flogopita com material esbranquiçado entre as placas, apresentando deformação; E) Grãos anedrais de ilmenita em meio à flogopita; e F) Ortopiroxênio anedral e pulverulento em contato com flogopita e opacos. 

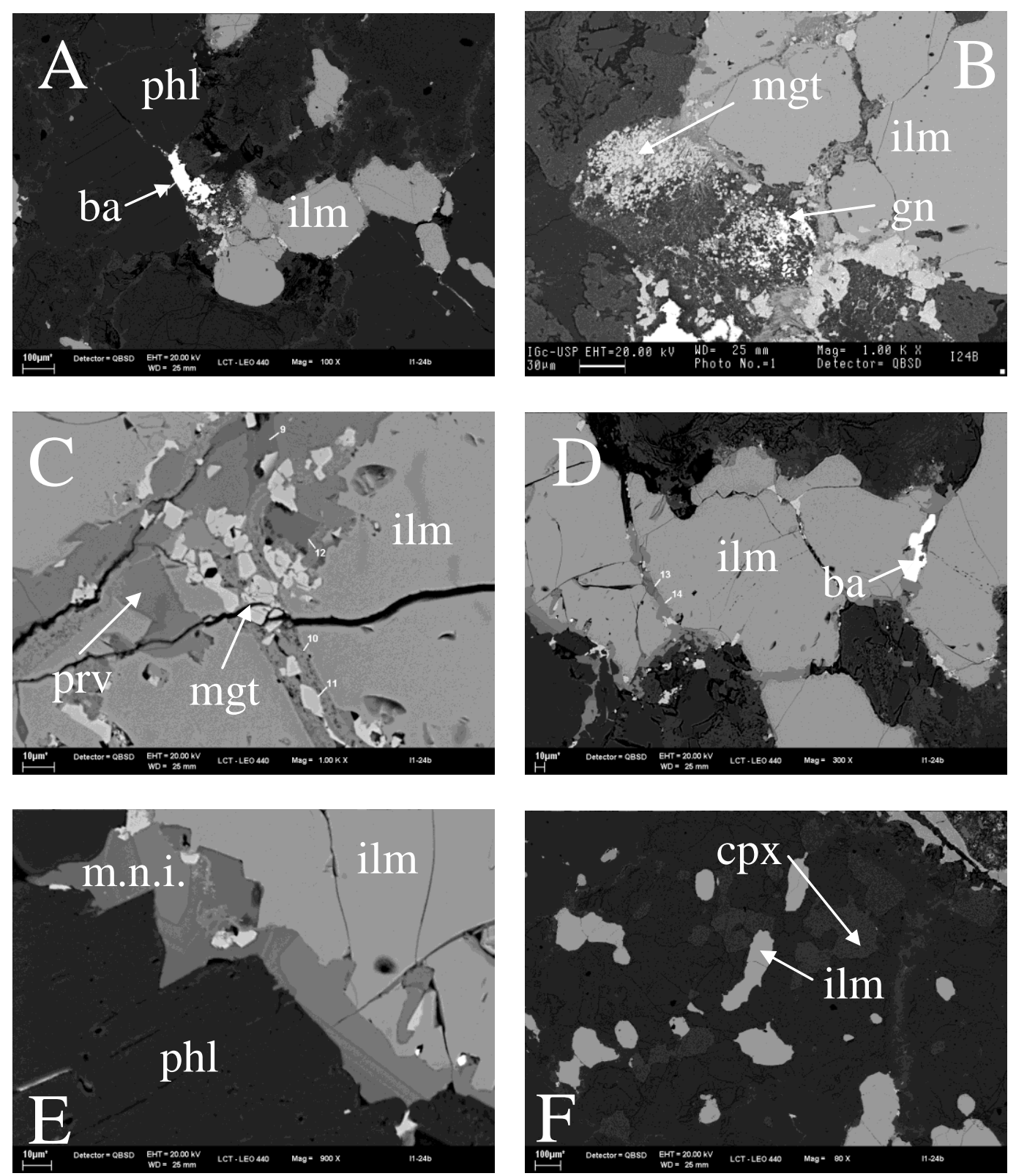

Figura 20- Imagem de microscópio eletrônico de varredura mostrando em detalhe os minerais pesados que compõem o xenólito de código In1/24b. A) Ilmenita em meio a cristais de flogopita e ortopiroxênio associada com barita; B) Detalhe de reação entre ilmenita magnetita e cromita; C) Perovskita, ilmenita e cromita; D) Desenvolvimento de perovskita nas fraturas; E) Mineral não identificado (de Ti, Si e Ca), e sua gradação de cor e composição; F) Ilmenita globular. Legenda: ba - barita, m.n.i. - mineral não identificado e gn-galena. 


\subsection{Xenólito polimítico}

Este xenólito corresponde a um fragmento arredondado de coloração cinza escuro, que ocorre na amostra In1/6, composto por olivina, clinopiroxênio, ilmenita, flogopita, perovskita, magnetita, zircão e outros minerais exóticos (Figura 21). Por conta dos padrões texturais distintos dentro de um mesmo xenólito, optou-se por utilizar o nome xenólito polimítico (Pearson et al. 2003) para esta amostra. Foram identificados os seguintes setores da amostra com textura distinta: um primeiro onde olivina e ilmenita formam uma textura gráfica; um segundo no qual ocorre clinopiroxênio poiquilítico e ilmenita xenomórfica arredondada; e um terceiro onde ocorrem vênulas de flogopita associadas a clinopiroxênio. Foi possível observar bordas finas de cromita+perovskita+magnetita na ilmenita em estudos de microscopia eletrônica de varredura (Figura 22). Também foi identificada a presença de um macrocristal de zircão idiomórfico sobrecrescido por inúmeros cristais menores de badeleíta acicular, associado a um macrocristal de ilmenita (Figura 22). Zircão é fase rara em xenólitos, mas existem diversos trabalhos com citações sobre este tipo de ocorrência, como Zheng et al. (2006) e Haggerty (1995), que também descreve badeleíta acicular associada ao zircão.

A textura gráfica pode ser reflexo da desestabilização de um outro mineral pré existente, como a granada, ou da cristalização concomitante destas duas fases (Haggerty 1995). Os outros setores da amostra devem ter sido gerados pela interação com um fluido metassomático.

Neste trabalho foi feita uma tentativa de identificar titanatos exóticos nas amostras contendo evidências de metassomatismo, tomando como exemplo os minerais mathiasita e lindsleyta (Haggerty et al. 1983) encontrados por Almeida (2008) na intrusão vizinha, o Kimberlito Limeira, porém não foram encontrados tais titanatos. 

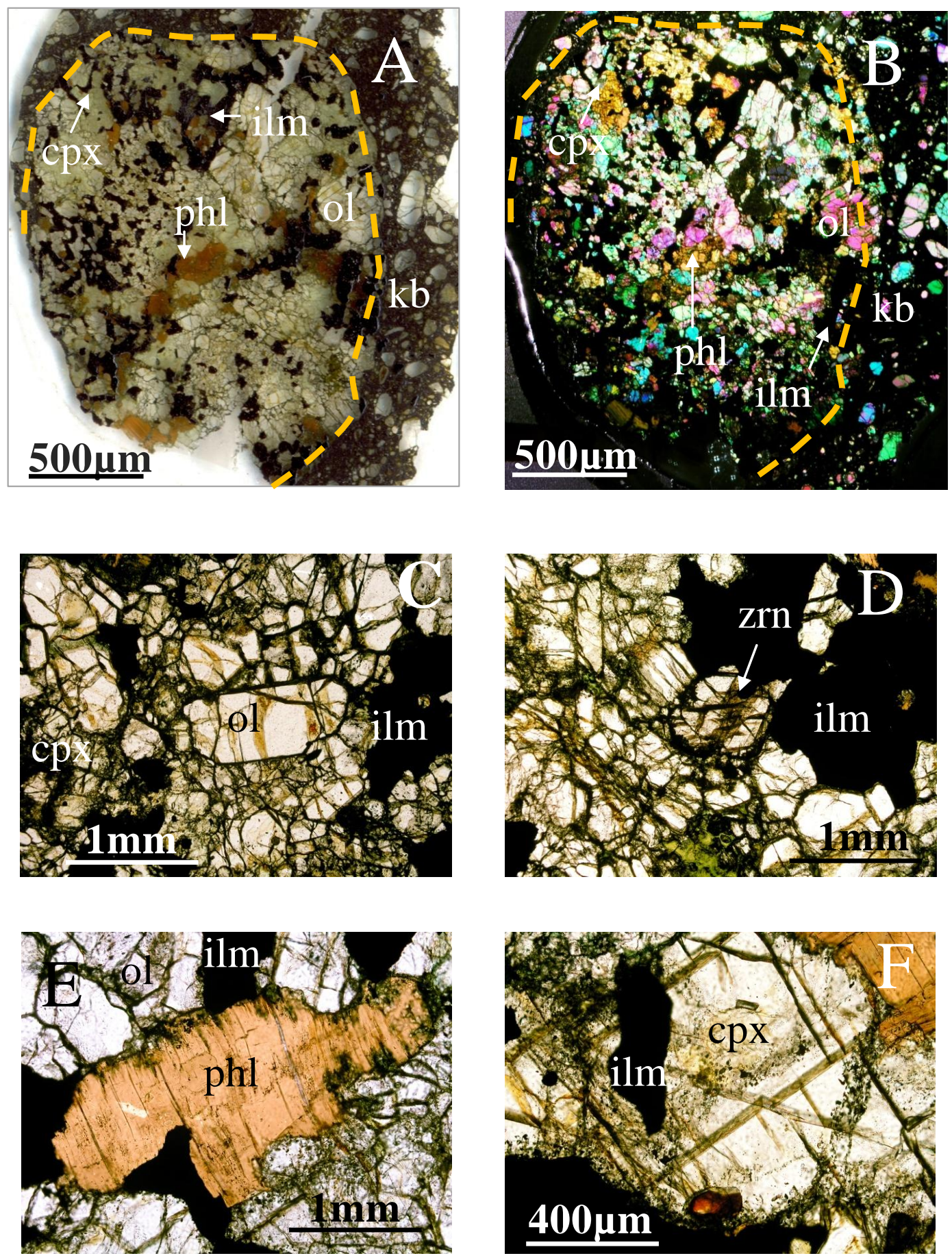

Figura 21- Seção In1/6 representando xenólito polimítico. A) Imagem de scanner mostrando a seção delgada em sua totalidade; B) Imagem de seção delgada obtida pela montagem de micrografia obtida em microscópio com polarizadores cruzados; C) Grãos euédricos de olivina fraturados em meio a minerais menores pulverulentos; D) Zircão idiomórfico em contato com opacos, clinopiroxênio e olivina; E) Macrocristal de flogopita em associação com minerais opacos; e F) Clinopiroxênio com inclusões e clivagem proeminente. Legenda: zrn-zircão. 

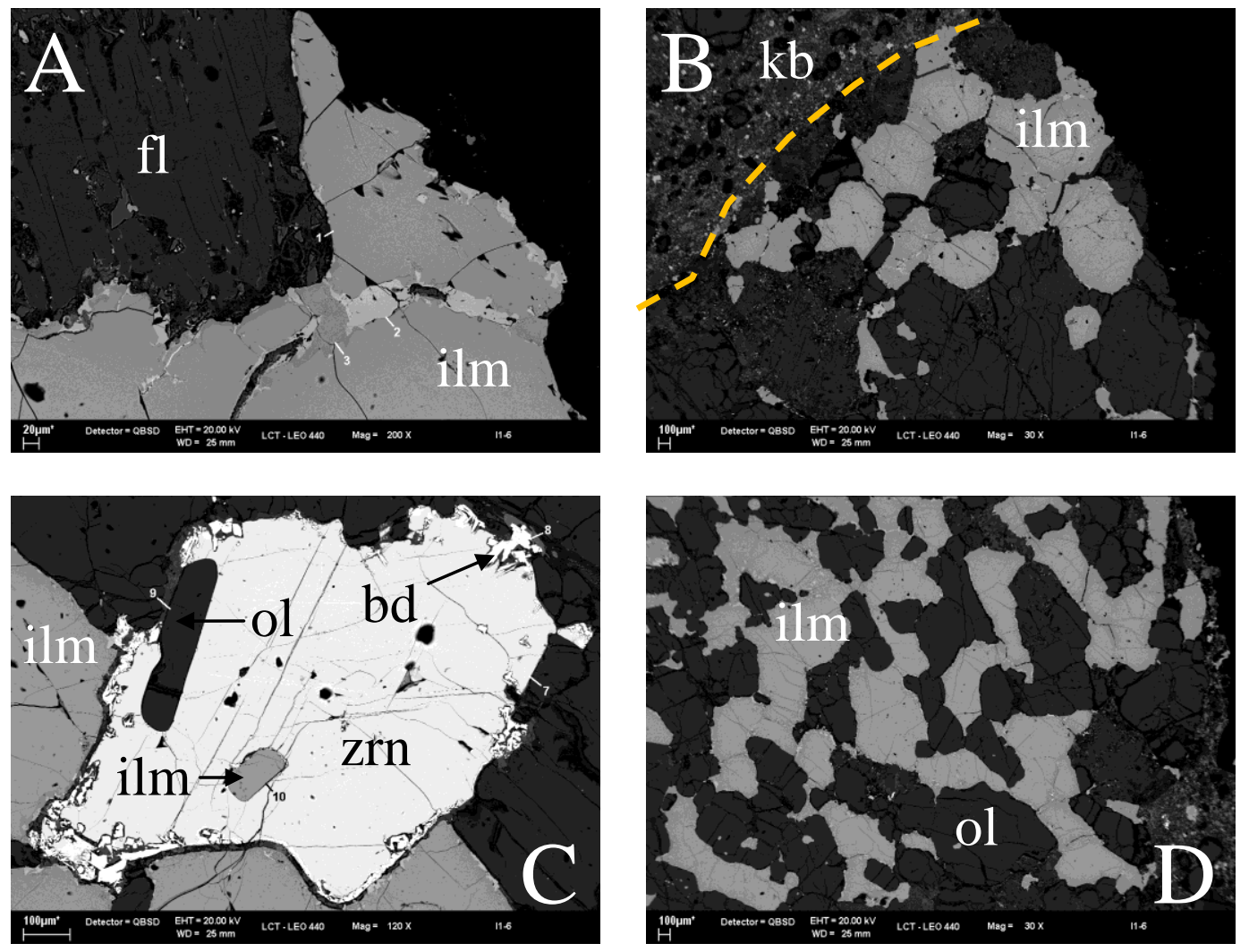

Figura 22- Imagem de microscópio eletrônico de varredura mostrando em detalhe os minerais opacos que compõem o xenólito de código In1/6. A) Ilmenita em associação com cromita; B) ilmenita com forma anedral a globular entre as placas de mica; C) Zircão bordejado parcialmente por badeleíta, com inclusões de ilmenita e olivina; D) textura gráfica entre ilmenita, olivina e ortopiroxênio. Legenda: bd- badeleíta. 


\section{QUÍMICA MINERAL}

Este capítulo apresenta os resultados e discussões sobre a química mineral das fases presentes nos xenólitos do Kimberlito Indaiá, contendo as informações completas dos dados apresentados no Simpósio de Geologia do Diamante, em Nannini et al. (2010b). Para a apresentação das tabelas de dados químicos contidas neste capítulo foram adotados códigos que identificam a amostra (antes da barra) e o número de análise na respectiva amostra (depois da barra), por exemplo: o primeiro ponto de análise na amostra In1/3 está representado pelo código 3/1, o terceiro ponto de análise na amostra In1/14a está representado pelo código 14a/3, e assim por diante.

\subsection{Olivina}

Dentro do conjunto de xenólitos mantélicos estudados a olivina é o mineral mais abundante, como está projetado no diagrama da Figura 5B. Neste mineral as principais variações químicas registradas pela microssonda eletrônica são os teores de $\mathrm{FeO}, \mathrm{MgO}$ e $\mathrm{NiO}$ (Tabela 5).

Em geral o teor da molécula forsterita (Fo) varia de 84 a 93. Entre os elementos menores principais $\mathrm{NiO}$ varia de 0,27 a $0,47 \%$ e $\mathrm{MnO}$ varia de 0,05 a $0,20 \%$. Nos harzburgitos, os valores de Fo são de 90 a 93; NiO varia de 0,36 a 0,44\% e MnO de 0,07 a 0,14\%. Nos lherzolitos, Fo varia de 91 a 92\%, $\mathrm{NiO} 0,36$ a 0,44\% e $\mathrm{MnO} 0,05$ a 0,16\%. Nos dunitos, Fo tem valor 89para o flogopita dunito (In1/2), com $\mathrm{NiO} 0,34-0,41 \%$ e $\mathrm{MnO} 0,14-0,17 \%$; e varia de 92 a 93 para o dunito com textura granoblástica (In1/24a), com NiO 0,40-0,47\% e MnO 0,09-0,13\%. Para o xenólito polimítico da amostra In1/6 Fo tem valor 83 a 84, NiO 0,22 a 0,27\% e MnO 0,12-0,20\%.

A composição das rochas tem correlação com a química das olivinas dos xenólitos estudados. As olivinas dos harzburgitos e dunitos (sem flogopita) em geral apresentam os mais altos valores de Fo, em relação aos lherzolitos. A olivina do flogopita dunito notadamente tem menos Fo que os tipos descritos acima, e o xenólito polimítico apresenta o menor valor de Fo entre os xenólitos. Utilizando o diagrama da Figura 23, de $\mathrm{NiO}$ vs. $\mathrm{Mg} /(\mathrm{Mg}+\mathrm{Fe})$ adaptado de Zhang et al. (2010), que delimita campos de peridotitos cratônicos, não cratônicos e piroxenitos cumuláticos, nota-se que as olivinas dos harzburgitos projetam no campo de peridotitos cratônicos e os dunitos projetam-se entre os campos peridotitos cratônicos e não-cratônicos. Já os 
lherzolitos e os flogopita dunito são projetados mais próximos ao campo de peridotitos mantélicos não-cratônicos. 
Tabela 5 - Análises químicas de olivina de xenólitos da intrusão Indaiá 1, obtidas por meio da microssonda eletrônica.

\begin{tabular}{|c|c|c|c|c|c|c|c|c|c|c|c|c|c|c|c|c|c|}
\hline & \multicolumn{7}{|c|}{ Harzburgito com textura grossa } & \multicolumn{3}{|c|}{ Flogopita dunito } & \multicolumn{5}{|c|}{ Harzburgito com textura granoblástica } & \multicolumn{2}{|c|}{ Xenólito polimítico } \\
\hline & $1 / 1^{*}$ & $1 / 2^{*}$ & $1 / 3^{*}$ & $1 / 4 *$ & $1 / 5$ & $1 / 6$ & $1 / 7$ & $2 / 1$ & $2 / 2$ & $2 / 3$ & $3 / 2$ & $3 / 3$ & $3 / 4$ & $3 / 5$ & $3 / 6$ & $6 / 1$ & $6 / 2$ \\
\hline $\mathrm{SiO}_{2}^{2}$ & 40,45 & 39,87 & 39,95 & 39,68 & 40,44 & 41,40 & 40,82 & 39,95 & 40,31 & 40,69 & 40,51 & 41,25 & 41,05 & 40,16 & 40,27 & 39,43 & 39,26 \\
\hline $\mathrm{TiO}$ & 0,04 & 0,05 & 0,06 & 0,05 & 0,00 & 0,01 & 0,05 & 0,04 & 0,00 & 0,07 & 0,04 & 0,08 & 0,00 & 0,00 & 0,00 & 0,00 & 0,02 \\
\hline $\mathrm{Al} \mathrm{O}_{3}$ & 0,03 & 0,05 & 0,06 & 0,04 & 0,06 & 0,06 & 0,05 & 0,04 & 0,00 & 0,01 & 0,03 & 0,00 & 0,01 & 0,00 & 0,00 & 0,00 & 0,00 \\
\hline $\mathrm{FeO}$ & 10,03 & 11,29 & 11,36 & 10,43 & 8,15 & 8,32 & 8,11 & 10,65 & 11,13 & 11,18 & 7,49 & 8,00 & 7,74 & 7,16 & 7,23 & 15,84 & 15,91 \\
\hline $\mathrm{MnO}$ & 0,12 & 0,15 & 0,09 & 0,13 & 0,10 & 0,10 & 0,14 & 0,17 & 0,15 & 0,14 & 0,11 & 0,05 & 0,14 & 0,11 & 0,09 & 0,20 & 0,20 \\
\hline $\mathrm{MgO}$ & 49,26 & 48,83 & 49,39 & 49,45 & 51,11 & 50,77 & 50,42 & 49,42 & 49,19 & 49,82 & 50,13 & 51,59 & 51,19 & 50,29 & 50,87 & 45,21 & 45,30 \\
\hline $\mathrm{CaO}$ & 0,12 & 0,14 & 0,13 & 0,14 & 0,10 & 0,09 & 0,14 & 0,03 & 0,04 & 0,02 & 0,00 & 0,01 & 0,00 & 0,03 & 0,02 & 0,02 & 0,01 \\
\hline $\mathrm{Na}_{2}^{2} \mathrm{O}_{2}$ & 0,03 & 0,02 & 0,03 & 0,01 & 0,02 & 0,03 & 0,02 & 0,00 & 0,01 & 0,03 & 0,00 & 0,00 & 0,02 & 0,01 & 0,02 & 0,01 & 0,00 \\
\hline $\mathrm{KO}^{2}$ & 0,00 & 0,00 & 0,00 & 0,00 & 0,00 & 0,00 & 0,00 & 0,01 & 0,00 & 0,00 & 0,00 & 0,00 & 0,00 & 0,00 & 0,00 & 0,00 & 0,01 \\
\hline $\mathrm{CrO}$ & 0,10 & 0,07 & 0,09 & 0,11 & 0,15 & 0,15 & 0,10 & 0,02 & 0,02 & 0,01 & 0,00 & 0,02 & 0,03 & 0,00 & 0,00 & 0,04 & 0,00 \\
\hline $\mathrm{NiO}$ & 0,42 & 0,43 & 0,41 & 0,38 & 0,42 & 0,41 & 0,42 & 0,41 & 0,34 & 0,38 & 0,39 & 0,44 & 0,46 & 0,37 & 0,36 & 0,23 & 0,22 \\
\hline Total & 100,60 & 100,88 & 101,57 & 100,41 & 100,56 & 101,34 & 100,27 & 100,72 & 101,19 & 102,33 & 98,69 & 101,44 & 100,63 & 98,12 & 98,86 & 100,97 & 100,93 \\
\hline \multicolumn{18}{|c|}{ Número de cátions com base em 4 átomos de oxigênio } \\
\hline $\mathrm{Si}$ & 0,989 & 0,979 & 0,975 & 0,976 & 0,982 & 0,996 & 0,993 & 0,980 & 0,985 & 0,983 & 0,997 & 0,990 & 0,993 & 0,993 & 0,989 & 0,986 & 0,983 \\
\hline $\mathrm{Ti}$ & 0,001 & 0,001 & 0,001 & 0,001 & 0,000 & 0,000 & 0,001 & 0,001 & 0,000 & 0,001 & 0,001 & 0,002 & 0,000 & 0,000 & 0,000 & 0,000 & 0,000 \\
\hline $\mathrm{Al}$ & 0,001 & 0,001 & 0,002 & 0,001 & 0,002 & 0,002 & 0,001 & 0,001 & 0,000 & 0,000 & 0,001 & 0,000 & 0,000 & 0,000 & 0,000 & 0,000 & 0,000 \\
\hline $\mathrm{Fe}^{2}$ & 0,205 & 0,232 & 0,232 & 0,215 & 0,166 & 0,167 & 0,165 & 0,218 & 0,228 & 0,226 & 0,154 & 0,161 & 0,157 & 0,148 & 0,148 & 0,331 & 0,333 \\
\hline $\mathrm{Mn}$ & 0,002 & 0,003 & 0,002 & 0,003 & 0,002 & 0,002 & 0,003 & 0,004 & 0,003 & 0,003 & 0,002 & 0,001 & 0,003 & 0,002 & 0,002 & 0,004 & 0,004 \\
\hline $\mathrm{Mg}$ & 1,796 & 1,788 & 1,797 & 1,813 & 1,850 & 1,821 & 1,828 & 1,806 & 1,792 & 1,794 & 1,839 & 1,846 & 1,845 & 1,854 & 1,863 & 1,686 & 1,691 \\
\hline $\mathrm{Ca}$ & 0,003 & 0,004 & 0,003 & 0,004 & 0,003 & 0,002 & 0,004 & 0,001 & 0,001 & 0,001 & 0,000 & 0,000 & 0,000 & 0,001 & 0,000 & 0,001 & 0,000 \\
\hline $\mathrm{Na}$ & 0,002 & 0,001 & 0,001 & 0,001 & 0,001 & 0,001 & 0,001 & 0,000 & 0,000 & 0,001 & 0,000 & 0,000 & 0,001 & 0,000 & 0,001 & 0,000 & 0,000 \\
\hline K & 0,000 & 0,000 & 0,000 & 0,000 & 0,000 & 0,000 & 0,000 & 0,000 & 0,000 & 0,000 & 0,000 & 0,000 & 0,000 & 0,000 & 0,000 & 0,000 & 0,000 \\
\hline $\mathrm{Cr}$ & 0,002 & 0,001 & 0,002 & 0,002 & 0,003 & 0,003 & 0,002 & 0,000 & 0,000 & 0,000 & 0,000 & 0,000 & 0,001 & 0,000 & 0,000 & 0,001 & 0,000 \\
\hline $\mathrm{Ni}$ & 0,008 & 0,009 & 0,008 & 0,008 & 0,008 & 0,008 & 0,008 & 0,008 & 0,007 & 0,007 & 0,008 & 0,008 & 0,009 & 0,007 & 0,007 & 0,005 & 0,004 \\
\hline Total & 3,009 & 3,019 & 3,023 & 3,022 & 3,016 & 3,002 & 3,006 & 3,019 & 3,015 & 3,016 & 3,002 & 3,008 & 3,008 & 3,007 & 3,011 & 3,014 & 3,017 \\
\hline $\mathrm{Mg} /(\mathrm{Mg}+\mathrm{Fe})$ & 0,897 & 0,885 & 0,886 & 0,894 & 0,918 & 0,916 & 0,917 & 0,892 & 0,887 & 0,888 & 0,923 & 0,920 & 0,922 & 0,926 & 0,926 & 0,836 & 0,835 \\
\hline $\mathrm{Fe} /(\mathrm{Fe}+\mathrm{Mg})$ & 0,103 & 0,115 & 0,114 & 0,106 & 0,082 & 0,084 & 0,083 & 0,108 & 0,113 & 0,112 & 0,077 & 0,080 & 0,078 & 0,074 & 0,074 & 0,164 & 0,165 \\
\hline
\end{tabular}


Tabela 5- Continuação.

\begin{tabular}{|c|c|c|c|c|c|c|c|c|c|c|c|c|c|c|c|c|c|}
\hline & \multicolumn{2}{|c|}{ Xenólito polimítico } & \multicolumn{4}{|c|}{ Harzburgito com espinélio e textura grossa } & \multicolumn{4}{|c|}{ Harzburgito com bolsões de clinopiroxênio } & \multicolumn{3}{|c|}{ Lherzolito com espinélio } & \multicolumn{4}{|c|}{ Lherzolito com espinélio e textura grossa } \\
\hline & $6 / 3$ & $6 / 4$ & $9 / 1$ & $9 / 2$ & $9 / 3$ & $9 / 4$ & $12 / 1$ & $12 / 2$ & $12 / 3$ & $12 / 4$ & $13 \mathrm{a} / 1$ & $13 \mathrm{a} / 2$ & $13 \mathrm{a} / 3$ & $14 \mathrm{a} / 1$ & $14 \mathrm{a} / 2$ & $14 \mathrm{a} / 3$ & $14 \mathrm{a} / 4$ \\
\hline $\mathrm{SiO}_{2}^{2}$ & 39,52 & 39,39 & 40,89 & 40,85 & 40,94 & 40,61 & 41,21 & 41,10 & 41,72 & 41,01 & 40,59 & 41,59 & 41,25 & 40,34 & 40,48 & 40,85 & 40,88 \\
\hline $\mathrm{TiO}$ & 0,00 & 0,00 & 0,00 & 0,00 & 0,00 & 0,00 & 0,00 & 0,04 & 0,05 & 0,06 & 0,00 & 0,00 & 0,00 & 0,00 & 0,08 & 0,00 & 0,00 \\
\hline $\mathrm{Al} \mathrm{O}$ & 0,02 & 0,04 & 0,03 & 0,01 & 0,02 & 0,03 & 0,00 & 0,00 & 0,00 & 0,02 & 0,00 & 0,00 & 0,01 & 0,02 & 0,00 & 0,00 & 0,00 \\
\hline $\mathrm{FeO}$ & 15,39 & 15,36 & 8,79 & 8,55 & 9,01 & 8,78 & 7,85 & 7,36 & 7,62 & 7,47 & 7,63 & 8,04 & 8,65 & 8,28 & 8,53 & 8,84 & 8,96 \\
\hline $\mathrm{MnO}$ & 0,19 & 0,12 & 0,14 & 0,13 & 0,08 & 0,11 & 0,07 & 0,12 & 0,12 & 0,11 & 0,08 & 0,12 & 0,05 & 0,14 & 0,15 & 0,11 & 0,16 \\
\hline $\mathrm{MgO}$ & 45,21 & 44,58 & 51,57 & 51,82 & 51,64 & 51,98 & 52,02 & 51,14 & 51,64 & 51,51 & 50,21 & 51,20 & 51,04 & 51,02 & 51,08 & 51,93 & 51,56 \\
\hline $\mathrm{CaO}_{2}^{2}$ & 0,02 & 0,05 & 0,00 & 0,02 & 0,00 & 0,00 & 0,03 & 0,01 & 0,00 & 0,00 & 0,03 & 0,01 & 0,02 & 0,03 & 0,03 & 0,00 & 0,00 \\
\hline $\mathrm{Na}_{2}^{2} \mathrm{O}$ & 0,02 & 0,01 & 0,00 & 0,01 & 0,00 & 0,00 & 0,00 & 0,03 & 0,00 & 0,01 & 0,01 & 0,00 & 0,00 & 0,03 & 0,02 & 0,02 & 0,00 \\
\hline $\mathrm{K}^{2} \mathrm{O}^{3}$ & 0,00 & 0,00 & 0,00 & 0,00 & 0,00 & 0,01 & 0,00 & 0,00 & 0,00 & 0,01 & 0,01 & 0,00 & 0,00 & 0,00 & 0,01 & 0,01 & 0,01 \\
\hline $\mathrm{CrO}$ & 0,03 & 0,00 & 0,00 & 0,01 & 0,01 & 0,00 & 0,00 & 0,00 & 0,05 & 0,00 & 0,01 & 0,00 & 0,02 & 0,01 & 0,01 & 0,03 & 0,01 \\
\hline $\mathrm{NiO}$ & 0,22 & 0,27 & 0,38 & 0,41 & 0,40 & 0,40 & 0,44 & 0,39 & 0,37 & 0,43 & 0,39 & 0,42 & 0,44 & 0,43 & 0,38 & 0,41 & 0,42 \\
\hline Total & 100,62 & 99,82 & 101,80 & 101,79 & 102,11 & 101,92 & 101,63 & 100,20 & 101,57 & 100,62 & 98,96 & 101,37 & 101,47 & 100,29 & 100,78 & 102,18 & 101,98 \\
\hline \multicolumn{18}{|c|}{ Número de cátions com base em 4 átomos de oxigênio } \\
\hline $\mathrm{Si}$ & 0,990 & 0,994 & 0,982 & 0,981 & 0,982 & 0,976 & 0,987 & 0,996 & 0,997 & 0,990 & 0,997 & 0,998 & 0,992 & 0,983 & 0,982 & 0,979 & 0,982 \\
\hline $\mathrm{Ti}$ & 0,000 & 0,000 & 0,000 & 0,000 & 0,000 & 0,000 & 0,000 & 0,001 & 0,001 & 0,001 & 0,000 & 0,000 & 0,000 & 0,000 & 0,002 & 0,000 & 0,000 \\
\hline $\mathrm{Al}$ & 0,001 & 0,001 & 0,001 & 0,000 & 0,001 & 0,001 & 0,000 & 0,000 & 0,000 & 0,001 & 0,000 & 0,000 & 0,000 & 0,001 & 0,000 & 0,000 & 0,000 \\
\hline $\mathrm{Fe}^{2}$ & 0,322 & 0,324 & 0,177 & 0,172 & 0,181 & 0,176 & 0,157 & 0,149 & 0,152 & 0,151 & 0,157 & 0,161 & 0,174 & 0,169 & 0,173 & 0,177 & 0,180 \\
\hline $\mathrm{Mn}$ & 0,004 & 0,003 & 0,003 & 0,003 & 0,002 & 0,002 & 0,002 & 0,003 & 0,002 & 0,002 & 0,002 & 0,002 & 0,001 & 0,003 & 0,003 & 0,002 & 0,003 \\
\hline $\mathrm{Mg}$ & 1,687 & 1,677 & 1,847 & 1,855 & 1,846 & 1,861 & 1,858 & 1,847 & 1,840 & 1,855 & 1,839 & 1,832 & 1,830 & 1,853 & 1,847 & 1,855 & 1,846 \\
\hline $\mathrm{Ca}$ & 0,001 & 0,001 & 0,000 & 0,001 & 0,000 & 0,000 & 0,001 & 0,000 & 0,000 & 0,000 & 0,001 & 0,000 & 0,000 & 0,001 & 0,001 & 0,000 & 0,000 \\
\hline $\mathrm{Na}$ & 0,001 & 0,000 & 0,000 & 0,000 & 0,000 & 0,000 & 0,000 & 0,002 & 0,000 & 0,001 & 0,001 & 0,000 & 0,000 & 0,001 & 0,001 & 0,001 & 0,000 \\
\hline $\mathrm{K}$ & 0,000 & 0,000 & 0,000 & 0,000 & 0,000 & 0,000 & 0,000 & 0,000 & 0,000 & 0,000 & 0,000 & 0,000 & 0,000 & 0,000 & 0,000 & 0,000 & 0,000 \\
\hline $\mathrm{Cr}$ & 0,001 & 0,000 & 0,000 & 0,000 & 0,000 & 0,000 & 0,000 & 0,000 & 0,001 & 0,000 & 0,000 & 0,000 & 0,000 & 0,000 & 0,000 & 0,001 & 0,000 \\
\hline $\mathrm{Ni}$ & 0,005 & 0,006 & 0,007 & 0,008 & 0,008 & 0,008 & 0,009 & 0,008 & 0,007 & 0,008 & 0,008 & 0,008 & 0,008 & 0,008 & 0,008 & 0,008 & 0,008 \\
\hline Total & 3,010 & 3,006 & 3,017 & 3,019 & 3,018 & 3,024 & 3,013 & 3,005 & 3,002 & 3,009 & 3,003 & 3,002 & 3,007 & 3,018 & 3,017 & 3,022 & 3,019 \\
\hline $\mathrm{Mg} /(\mathrm{Mg}+\mathrm{Fe})$ & 0,840 & 0,838 & 0,913 & 0,915 & 0,911 & 0,913 & 0,922 & 0,925 & 0,924 & 0,925 & 0,922 & 0,919 & 0,913 & 0,917 & 0,914 & 0,913 & 0,911 \\
\hline $\mathrm{Fe} /(\mathrm{Fe}+\mathrm{Mg})$ & 0,160 & 0,162 & 0,087 & 0,085 & 0,089 & 0,087 & 0,078 & 0,075 & 0,076 & 0,075 & 0,078 & 0,081 & 0,087 & 0,083 & 0,086 & 0,087 & 0,089 \\
\hline
\end{tabular}


Tabela 5- Continuação.

\begin{tabular}{cccc|cc}
\multicolumn{7}{c}{ Lherzolito com espinélio } & & \\
& $14 \mathrm{a} / 5$ & $14 \mathrm{a} / 6$ & $14 \mathrm{a} / 7$ & $20 \mathrm{~b} / 1$ & $20 \mathrm{~b} / 2$ \\
$\mathrm{SiO}_{2}^{2}$ & 40,84 & 40,79 & 40,61 & 40,88 & 40,77 \\
$\mathrm{TiO}$ & 0,01 & 0,05 & 0,00 & 0,00 & 0,00 \\
$\mathrm{Al} \mathrm{O}$ & 0,00 & 0,00 & 0,00 & 0,03 & 0,02 \\
$\mathrm{FeO}$ & 8,70 & 8,76 & 8,51 & 6,85 & 6,95 \\
$\mathrm{MnO}$ & 0,12 & 0,12 & 0,11 & 0,09 & 0,10 \\
$\mathrm{MgO}$ & 51,23 & 51,18 & 51,88 & 51,90 & 51,16 \\
$\mathrm{CaO}$ & 0,00 & 0,01 & 0,02 & 0,02 & 0,05 \\
$\mathrm{Na}$ & 0,00 & 0,00 & 0,00 & 0,01 & 0,01 \\
$\mathrm{~N} \mathrm{O}_{3}$ & 0,00 & 0,00 & 0,00 & 0,00 & 0,02 \\
$\mathrm{~K} \mathrm{O}$ & 0,00 & 0,03 & 0,00 & 0,02 & 0,04 \\
$\mathrm{Cr} \mathrm{O}$ & 0,36 & 0,43 & 0,40 & 0,44 & 0,37 \\
$\mathrm{NiO}$ & 101,25 & 101,36 & 101,53 & 100,25 & 99,48 \\
$\mathrm{Total}$ & & & & & \\
& & & & & \\
$\mathrm{Si}$ & 0,986 & 0,984 & 0,978 & 0,989 & 0,994 \\
$\mathrm{Ti}$ & 0,000 & 0,001 & 0,000 & 0,000 & 0,000 \\
$\mathrm{Al}$ & 0,000 & 0,000 & 0,000 & 0,001 & 0,001 \\
$\mathrm{Fe}{ }^{2}$ & 0,176 & 0,177 & 0,171 & 0,139 & 0,142 \\
$\mathrm{Mn}$ & 0,002 & 0,002 & 0,002 & 0,002 & 0,002 \\
$\mathrm{Mg}$ & 1,843 & 1,841 & 1,863 & 1,871 & 1,858 \\
$\mathrm{Ca}$ & 0,000 & 0,000 & 0,000 & 0,001 & 0,001 \\
$\mathrm{Na}$ & 0,000 & 0,000 & 0,000 & 0,001 & 0,000 \\
$\mathrm{~K}$ & 0,000 & 0,000 & 0,000 & 0,000 & 0,001 \\
$\mathrm{Cr}$ & 0,000 & 0,001 & 0,000 & 0,000 & 0,001 \\
$\mathrm{Ni}$ & 0,007 & 0,008 & 0,008 & 0,009 & 0,007 \\
$\mathrm{Total}$ & 3,014 & 3,015 & 3,022 & 3,011 & 3,006 \\
$\mathrm{Mg} / \mathrm{Mg}+\mathrm{Fe})$ & 0,913 & 0,912 & 0,916 & 0,931 & 0,929 \\
$\mathrm{Fe} /(\mathrm{Fe}+\mathrm{Mg})$ & 0,087 & 0,088 & 0,084 & 0,069 & 0,071 \\
& & & & &
\end{tabular}

\begin{tabular}{cccc|r} 
Harzburgito com flogopita & \multicolumn{1}{l|}{} \\
$20 \mathrm{~b} / 3$ & $20 \mathrm{~b} / 4$ & $20 \mathrm{~b} / 5$ & $20 \mathrm{~b} / 6$ & $24 \mathrm{a} / 1$ \\
39,84 & 40,22 & 40,38 & 41,45 & 40,59 \\
0,06 & 0,07 & 0,04 & 0,00 & 0,01 \\
0,03 & 0,05 & 0,02 & 0,06 & 0,00 \\
6,95 & 7,64 & 6,87 & 6,99 & 7,45 \\
0,10 & 0,10 & 0,10 & 0,09 & 0,13 \\
51,60 & 51,89 & 51,46 & 50,92 & 51,88 \\
0,06 & 0,05 & 0,09 & 0,03 & 0,03 \\
0,00 & 0,01 & 0,02 & 0,00 & 0,00 \\
0,01 & 0,00 & 0,02 & 0,00 & 0,00 \\
0,04 & 0,09 & 0,05 & 0,06 & 0,01 \\
0,39 & 0,37 & 0,39 & n.a. & 0,47 \\
99,08 & 100,50 & 99,45 & 99,607 & 100,56 \\
& Número de cátions com base em 4 átomos de oxigênio \\
0,977 & 0,975 & 0,985 & 1,005 & 0,982 \\
0,001 & 0,001 & 0,001 & 0,002 & 0,000 \\
0,001 & 0,002 & 0,001 & 0,000 & 0,000 \\
0,143 & 0,155 & 0,140 & 0,142 & 0,151 \\
0,002 & 0,002 & 0,002 & 0,002 & 0,003 \\
1,887 & 1,876 & 1,872 & 1,841 & 1,872 \\
0,002 & 0,001 & 0,002 & 0,001 & 0,001 \\
0,000 & 0,001 & 0,001 & 0,000 & 0,000 \\
0,000 & 0,000 & 0,001 & 0,000 & 0,000 \\
0,001 & 0,002 & 0,001 & 0,000 & 0,000 \\
0,008 & 0,007 & 0,008 & n.a. & 0,009 \\
3,021 & 3,022 & 3,014 & 2,993 & 3,017 \\
0,930 & 0,924 & 0,930 & 0,928 & 0,925 \\
0,070 & 0,076 & 0,070 & 0,072 & 0,075
\end{tabular}

Dunito com cromita e textura granoblástica

$\begin{array}{ccccccc}24 \mathrm{a} / 2 & 24 \mathrm{a} / 3 & 24 \mathrm{a} / 4 & 24 \mathrm{a} / 5 & 24 \mathrm{a} / 6 & 24 \mathrm{a} / 7 & 24 \mathrm{a} / 8 \\ 40,65 & 40,27 & 40,73 & 40,91 & 41,07 & 41,08 & 41,54 \\ 0,00 & 0,04 & 0,00 & 0,00 & 0,06 & 0,08 & 0,00 \\ 0,02 & 0,00 & 0,01 & 0,00 & 0,01 & 0,00 & 0,00 \\ 7,58 & 8,02 & 7,99 & 7,95 & 8,17 & 7,54 & 6,95 \\ 0,09 & 0,11 & 0,08 & 0,10 & 0,10 & 0,12 & 0,13 \\ 51,91 & 52,30 & 51,84 & 51,46 & 52,10 & 51,47 & 51,35 \\ 0,00 & 0,00 & 0,00 & 0,00 & 0,02 & 0,00 & 0,02 \\ 0,00 & 0,00 & 0,01 & 0,00 & 0,00 & 0,00 & 0,00 \\ 0,00 & 0,02 & 0,00 & 0,00 & 0,00 & 0,00 & 0,00 \\ 0,00 & 0,02 & 0,00 & 0,00 & 0,00 & 0,00 & 0,00 \\ 0,42 & 0,40 & 0,42 & 0,41 & 0,42 & \text { n.a. } & \text { n.a. } \\ 100,67 & 101,15 & 101,08 & 100,83 & 101,96 & 100,307 & 99,99 \\ & & & & & & \\ & & & & & & \\ 0,983 & 0,972 & 0,982 & 0,988 & 0,983 & 0,993 & 1,003 \\ 0,000 & 0,001 & 0,000 & 0,000 & 0,001 & 0,000 & 0,000 \\ 0,001 & 0,000 & 0,000 & 0,000 & 0,000 & 0,002 & 0,000 \\ 0,153 & 0,162 & 0,161 & 0,161 & 0,163 & 0,152 & 0,140 \\ 0,002 & 0,002 & 0,002 & 0,002 & 0,002 & 0,003 & 0,003 \\ 1,871 & 1,882 & 1,864 & 1,853 & 1,858 & 1,855 & 1,849 \\ 0,000 & 0,000 & 0,000 & 0,000 & 0,001 & 0,000 & 0,000 \\ 0,000 & 0,000 & 0,001 & 0,000 & 0,000 & 0,000 & 0,000 \\ 0,000 & 0,001 & 0,000 & 0,000 & 0,000 & 0,000 & 0,000 \\ 0,000 & 0,000 & 0,000 & 0,000 & 0,000 & 0,000 & 0,000 \\ 0,008 & 0,008 & 0,008 & 0,008 & 0,008 & \text { n.a. } & \text { n.a. } \\ 3,017 & 3,028 & 3,018 & 3,012 & 3,016 & 3,005 & 2,995 \\ 0,924 & 0,921 & 0,920 & 0,920 & 0,919 & 0,924 & 0,930 \\ 0,076 & 0,079 & 0,080 & 0,080 & 0,081 & 0,076 & 0,070\end{array}$




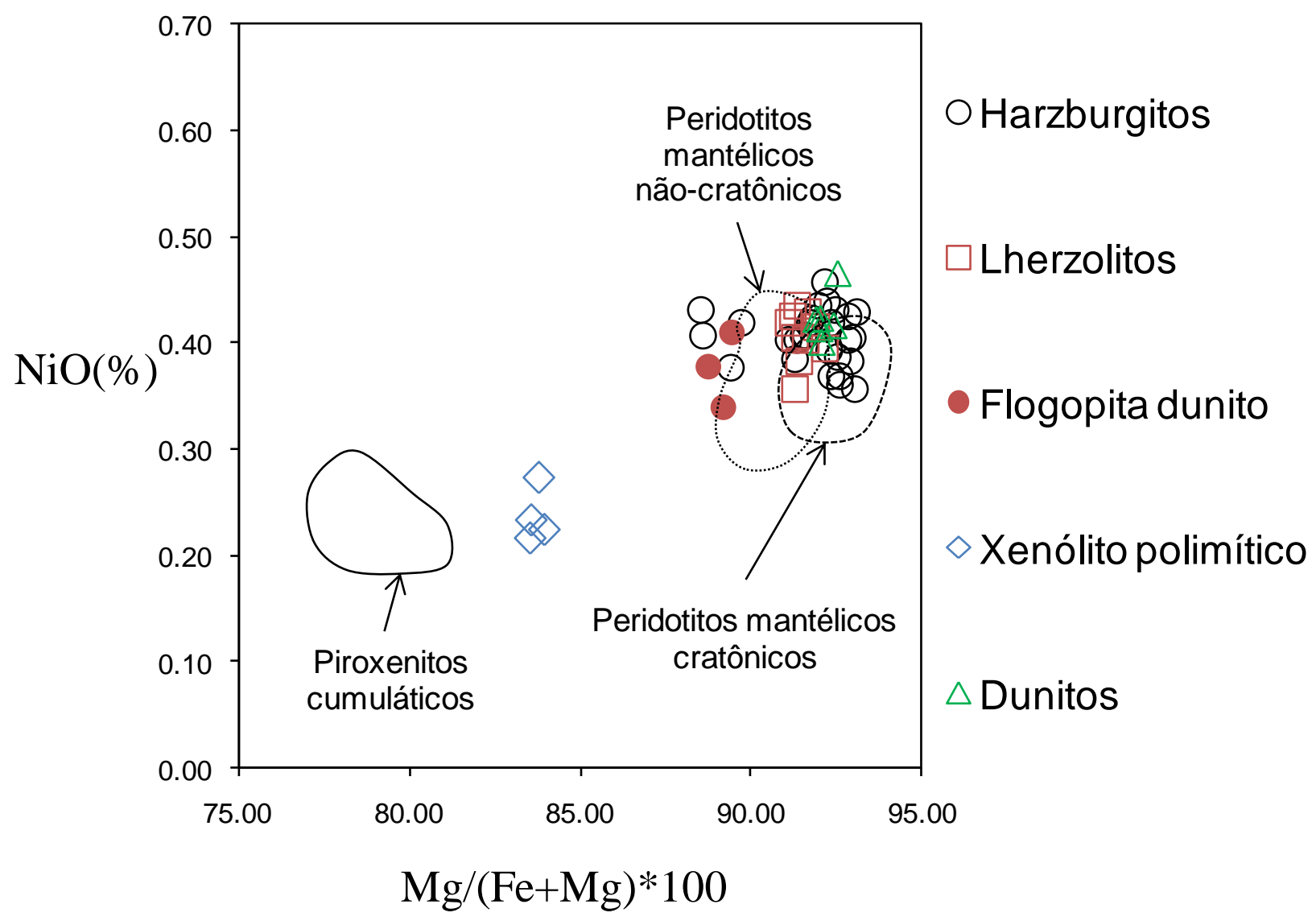

Figura 23- Composição de olivinas de xenólitos do Kimberlito Indaiá mostrando os campos de peridotitos mantélicos e piroxenitos cumuláticos, com dados de referência extraídos de Zhang et al., 2010. Os xenólitos estudados reúnem-se em quatro grupos distintos: a) harzburgitos e dunitos, e b) lherzolitos que se projetam no campo dos peridotitos mantélicos cratônicos; c) um segundo grupo de olivinas alteradas de harzburgitos de flogopita dunito, que projeta no campo dos peridotitos não cratônicos; e d) grupo dos xenólitos polimíticos, sem correspondência com os dados utilizados. 


\subsection{Ortopiroxênio}

O ortopiroxênio é o segundo mineral mais abundante nos xenólitos estudados, como mostra a Figura 5B. Nas amostras estudadas os teores de $\mathrm{MgO}, \mathrm{FeO}, \mathrm{CaO}, \mathrm{Al}_{2} \mathrm{O}_{3}$ e $\mathrm{Cr}_{2} \mathrm{O}_{3}$ têm variação significativa. A Tabela 6 mostra os valores das análises químicas para este mineral.

No ortopiroxênio a variação no teor das moléculas wollastonita (Wo), enstatita (En) e ferrossilita (Fs) é de respectivamente 0,1-3\%, 84-93\% e 7-14\%. Nos harzburgitos, a variação é de 0,1 a $3 \%$ de Wo, $86-93 \%$ de En e 6-10\% de Fs; $0,11-3,34 \%$ de $\mathrm{Al}_{2} \mathrm{O}_{3}$ e 0,34 a $0,89 \%$ de $\mathrm{Cr}_{2} \mathrm{O}_{3}$. Nos lherzolitos, Wo, En e Fs têm variações de respectivamente 0,2-0,8\%, 90-92\% e 7$10 \%$; 1,5-8,62\% de $\mathrm{Al}_{2} \mathrm{O}_{3}$ e 0,19-1,17\% de $\mathrm{Cr}_{2} \mathrm{O}_{3}$. Nos dunitos os valores de Wo, En e Fs são respectivamente $1 \%, 89 \%$ e $10 \%$ para o flogopita dunito ( $\mathrm{In} 1 / 2)$, com $\mathrm{Al}_{2} \mathrm{O}_{3} 0,18-0,23 \%$ e $\mathrm{Cr}_{2} \mathrm{O}_{3}$ 0,23-0,26\%; e 0,5-1\%, 91-92\% e 7-8\% para o dunito com textura granoblástica (In1/24a), com $\mathrm{Al}_{2} \mathrm{O}_{3}$ 1,40-1,70\% e $\mathrm{Cr}_{2} \mathrm{O}_{3}$ 0,27-0,48\%. Para o mica piroxenito da amostra In1/24b Wo, En e Fs são respectivamente 1-2,7\%, 84-86\% e 13-14\%; $\mathrm{Al}_{2} \mathrm{O}_{3} 0,21-0,31 \%$ e $\mathrm{Cr}_{2} \mathrm{O}_{3} 0,02-0,14 \%$.

Os ortopiroxênios estudados foram classificados como enstatita, segundo os critérios de Morimoto et al. (1988), como está apresentado na Figura 24.

Assim como ocorre com as olivinas, a composição química tem relação direta com a composição das rochas, principalmente no tocante aos teores de Fe e Mg. Nos harzburgitos e dunitos os valores de En são os maiores, enquanto que nos lherzolitos e flogopita dunito os teores de En são menores. Já para os mica piroxenitos o teor de Fs é o maior entre todas as amostras, como mostra a Figura 24. 
Tabela 6- Análises químicas de ortopiroxênio de xenólitos da intrusão Indaiá 1, obtidas por meio da microssonda eletrônica.

\begin{tabular}{|c|c|c|c|c|c|c|c|c|c|c|c|}
\hline \multicolumn{10}{|c|}{ Harzburgito com textura grossa } & \multicolumn{2}{|c|}{ Flogopita dunito } \\
\hline 2 & $1 / 1^{*}$ & $1 / 2^{*}$ & $1 / 3 *$ & $1 / 4$ & $1 / 5$ & $1 / 6$ & $1 / 7$ & $1 / 8$ & $1 / 9$ & $2 / 1$ & $2 / 2$ \\
\hline $\mathrm{SiO}_{3}^{2}$ & 56,09 & 56,79 & 56,63 & 58,12 & 58,66 & 57,66 & 58,07 & 57,82 & 56,32 & 57,34 & 57,71 \\
\hline $\mathrm{TiO}^{2}$ & 0,28 & 0,27 & 0,29 & 0,16 & 0,00 & 0,00 & 0,10 & 0,17 & 0,22 & 0,18 & 0,22 \\
\hline $\mathrm{Al} \mathrm{O}$ & 1,28 & 1,22 & 1,20 & 0,96 & 1,29 & 1,22 & 1,28 & 1,24 & 1,54 & 0,23 & 0,18 \\
\hline $\mathrm{FeO}$ & 6,92 & 6,49 & 6,23 & 5,37 & 5,13 & 4,84 & 4,73 & 4,74 & 4,69 & 6,82 & 6,69 \\
\hline $\mathrm{MnO}$ & 0,12 & 0,15 & 0,11 & 0,09 & 0,14 & 0,10 & 0,12 & 0,11 & 0,12 & 0,20 & 0,17 \\
\hline $\mathrm{MgO}$ & 33,61 & 33,87 & 33,48 & 35,59 & 36,38 & 36,48 & 36,65 & 35,54 & 33,89 & 33,66 & 33,61 \\
\hline $\mathrm{CaO}$ & 1,67 & 1,47 & 1,41 & 0,90 & 0,19 & 0,28 & 0,26 & 0,66 & 1,27 & 0,53 & 0,62 \\
\hline $\mathrm{Na}_{2}^{2} \mathrm{O}_{3}$ & 0,21 & 0,17 & 0,17 & 0,11 & 0,08 & 0,06 & 0,08 & 0,14 & 0,13 & 0,06 & 0,05 \\
\hline $\mathrm{K}^{2} \mathrm{O}^{3}$ & 0,12 & 0,00 & 0,03 & 0,02 & 0,01 & 0,02 & 0,01 & 0,00 & 0,03 & 0,01 & 0,00 \\
\hline $\mathrm{CrO}$ & 0,64 & 0,67 & 0,64 & 0,34 & 0,35 & 0,35 & 0,35 & 0,46 & 0,89 & 0,23 & 0,26 \\
\hline Total & 100,94 & 101,09 & 100,18 & 101,64 & 102,22 & 101,01 & 101,64 & 100,87 & 99,10 & 99,24 & 99,50 \\
\hline \multicolumn{12}{|c|}{ Número de cátions com base em 6 átomos de oxigênio } \\
\hline TSi & 1,923 & 1,943 & 1,955 & 1,962 & 1,964 & 1,949 & 1,951 & 1,964 & 1,956 & 2,000 & 2,009 \\
\hline TAl & 0,052 & 0,049 & 0,045 & 0,038 & 0,036 & 0,049 & 0,049 & 0,036 & 0,044 & 0,000 & 0,000 \\
\hline $\mathrm{TFe} 3$ & 0,025 & 0,008 & 0,000 & 0,000 & 0,000 & 0,002 & 0,000 & 0,000 & 0,000 & 0,000 & 0,000 \\
\hline M1Al & 0,000 & 0,000 & 0,004 & 0,001 & 0,015 & 0,000 & 0,001 & 0,013 & 0,019 & 0,009 & 0,007 \\
\hline M1Ti & 0,007 & 0,007 & 0,008 & 0,004 & 0,000 & 0,000 & 0,003 & 0,004 & 0,006 & 0,005 & 0,006 \\
\hline M1Fe3 & 0,064 & 0,036 & 0,021 & 0,028 & 0,017 & 0,046 & 0,039 & 0,011 & 0,000 & 0,000 & 0,000 \\
\hline M1Fe2 & 0,000 & 0,000 & 0,000 & 0,000 & 0,000 & 0,000 & 0,000 & 0,000 & 0,000 & 0,000 & 0,000 \\
\hline $\mathrm{M} 1 \mathrm{Cr}$ & 0,017 & 0,018 & 0,017 & 0,009 & 0,009 & 0,009 & 0,009 & 0,012 & 0,024 & 0,006 & 0,007 \\
\hline $\mathrm{M} 1 \mathrm{Mg}$ & 0,911 & 0,939 & 0,950 & 0,959 & 0,95 & 0,944 & 0,948 & 0,959 & 0,951 & 0,979 & 0,980 \\
\hline $\mathrm{M} 1 \mathrm{Ni}$ & 0,000 & 0,000 & 0,000 & 0,000 & 0,000 & 0,000 & 0,000 & 0,000 & 0,000 & 0,000 & 0,000 \\
\hline $\mathrm{M} 2 \mathrm{Mg}$ & 0,807 & 0,789 & 0,773 & 0,833 & 0,857 & 0,894 & 0,888 & 0,840 & 0,803 & 0,771 & 0,765 \\
\hline $\mathrm{M} 2 \mathrm{Fe} 2$ & 0,109 & 0,142 & 0,159 & 0,124 & 0,126 & 0,088 & 0,094 & 0,123 & 0,136 & 0,199 & 0,195 \\
\hline M2Mn & 0,003 & 0,004 & 0,003 & 0,003 & 0,004 & 0,003 & 0,003 & 0,003 & 0,004 & 0,006 & 0,005 \\
\hline $\mathrm{M} 2 \mathrm{Ca}$ & 0,061 & 0,054 & 0,052 & 0,033 & 0,007 & 0,010 & 0,009 & 0,024 & 0,047 & 0,020 & 0,023 \\
\hline $\mathrm{M} 2 \mathrm{Na}$ & 0,014 & 0,011 & 0,011 & 0,007 & 0,005 & 0,004 & 0,005 & 0,009 & 0,009 & 0,004 & 0,003 \\
\hline $\mathrm{M} 2 \mathrm{~K}$ & 0,005 & 0,000 & 0,001 & 0,001 & 0,000 & 0,001 & 0,000 & 0,000 & 0,001 & 0,000 & 0,000 \\
\hline Sum_cat & 3,995 & 4,000 & 3,999 & 3,999 & 4,000 & 3,999 & 4,000 & 4,0 & 3,999 & 4,000 & 4,000 \\
\hline $\mathrm{Ca}$ & 3,242 & 2,796 & 2,692 & 1,669 & 0,349 & 0,523 & 0,482 & 1,232 & 2,434 & 1,003 & 1,176 \\
\hline $\mathrm{Mg}$ & 90,792 & 89,621 & 88,939 & 91,846 & 92,979 & 94,775 & 94,503 & 92,286 & 90,369 & 88,625 & 88,669 \\
\hline Fe2_Mn & 5,965 & 7,583 & 8,369 & 6,485 & 6,672 & 4,702 & 5,015 & 6,482 & 7,197 & 10,373 & 10,156 \\
\hline JD1 & 0,000 & 0,000 & 0,201 & 0,030 & 0,283 & 0,000 & 0,072 & 0,469 & 0,518 & 0,228 & 0,172 \\
\hline $\mathrm{AE} 1$ & 1,003 & 0,583 & 0,451 & 0,382 & 0,000 & 0,242 & 0,212 & 0,000 & 0,000 & 0,000 & 0,000 \\
\hline CFTS1 & 3,241 & 2,216 & 1,521 & 1,498 & 1,339 & 2,558 & 2,219 & 1,209 & 1,253 & 0,321 & 0,364 \\
\hline CTTS1 & 0,377 & 0,359 & 0,387 & 0,208 & 0,000 & 0,000 & 0,128 & 0,221 & 0,295 & 0,000 & 0,000 \\
\hline CATS1 & 0,000 & 0,000 & 0,000 & 0,000 & 0,466 & 0,000 & 0,000 & 0,198 & 0,434 & 0,000 & 0,000 \\
\hline WO1 & 0,000 & 0,210 & 0,771 & 0,000 & 0,000 & 0,000 & 0,000 & 0,000 & 0,443 & 0,683 & 0,813 \\
\hline EN1 & 89,670 & 89,300 & 88,506 & 91,550 & 91,542 & 92,743 & 92,626 & 91,628 & 90,065 & 88,688 & 88,743 \\
\hline FS1 & 5,710 & 7,331 & 8,163 & 6,332 & 6,369 & 4,457 & 4,743 & 6,275 & 6,992 & 10,081 & 9,909 \\
\hline $\mathrm{Q}$ & 1,889 & 1,923 & 1,934 & 1,948 & 1,949 & 1,937 & 1,939 & 1,946 & 1,938 & 1,969 & 1,962 \\
\hline $\mathrm{J}$ & 0,028 & 0,023 & 0,023 & 0,014 & 0,010 & 0,008 & 0,010 & 0,018 & 0,018 & 0,008 & 0,007 \\
\hline WO & 3,097 & 2,733 & 2,663 & 1,646 & 0,346 & 0,510 & 0,472 & 1,225 & 2,434 & 1,003 & 1,176 \\
\hline EN & 86,712 & 87,627 & 87,988 & 90,559 & 92,162 & 92,464 & 92,648 & 91,749 & 90,369 & 88,625 & 88,669 \\
\hline FS & 10,191 & 9,640 & 9,349 & 7,795 & 7,492 & 7,026 & 6,880 & 7,026 & 7,197 & 10,373 & 10,156 \\
\hline WEF & 98,546 & 98,843 & 98,839 & 99,267 & 99,471 & 99,596 & 99,466 & 99,063 & 99,106 & 99,591 & 99,658 \\
\hline $\mathrm{JD}$ & 0,000 & 0,000 & 0,183 & 0,015 & 0,244 & 0,000 & 0,019 & 0,501 & 0,894 & 0,409 & 0,342 \\
\hline $\mathrm{AE}$ & 1,454 & 1,157 & 0,978 & 0,718 & 0,285 & 0,404 & 0,515 & 0,436 & 0,000 & 0,000 & 0,000 \\
\hline
\end{tabular}

* análises em porções alteradas da amostra, ocorre perda de Mg e e maior concentração de Fe nestes pontos. 
Tabela 6- Continuação.

\begin{tabular}{|c|c|c|c|c|c|c|c|c|c|c|c|c|c|}
\hline & \multicolumn{7}{|c|}{ Harzburgito com textura granoblástica } & \multicolumn{6}{|c|}{ Harzburgito com espinélio } \\
\hline 2 & $3 / 1$ & $3 / 2$ & $3 / 3$ & $3 / 4$ & $3 / 5$ & $3 / 6$ & $3 / 7$ & $9 / 1$ & $9 / 2$ & $9 / 3$ & $9 / 4$ & $9 / 5$ & $9 / 6$ \\
\hline $\mathrm{SiO}_{3}^{2}$ & 56,90 & 56,45 & 57,49 & 57,31 & 56,93 & 56,96 & 57,27 & 56,38 & 56,03 & 55,83 & 56,72 & 56,50 & 55,33 \\
\hline $\mathrm{TiO}^{3}$ & 0,11 & 0,07 & 0,06 & 0,06 & 0,00 & 0,07 & 0,07 & 0,09 & 0,06 & 0,06 & 0,01 & 0,10 & 0,04 \\
\hline $\mathrm{Al} \mathrm{O}$ & 1,42 & 1,66 & 1,65 & 1,76 & 1,87 & 1,90 & 1,66 & 2,30 & 2,72 & 3,34 & 2,37 & 2,86 & 2,87 \\
\hline $\mathrm{FeO}$ & 5,04 & 5,01 & 5,34 & 4,86 & 4,98 & 5,31 & 5,31 & 5,84 & 5,53 & 5,77 & 5,64 & 5,83 & 5,67 \\
\hline $\mathrm{MnO}$ & 0,13 & 0,12 & 0,13 & 0,11 & 0,14 & 0,15 & 0,13 & 0,16 & 0,17 & 0,19 & 0,15 & 0,12 & 0,18 \\
\hline $\mathrm{MgO}$ & 36,71 & 36,42 & 36,46 & 35,56 & 36,15 & 36,23 & 36,42 & 33,94 & 33,28 & 33,33 & 33,67 & 35,85 & 35,51 \\
\hline $\mathrm{CaO}$ & 0,26 & 0,43 & 0,45 & 0,61 & 0,32 & 0,21 & 0,47 & 0,14 & 0,12 & 0,14 & 0,07 & 0,14 & 0,21 \\
\hline $\mathrm{Na}_{2}^{2} \mathrm{O}_{3}$ & 0,00 & 0,03 & 0,04 & 0,00 & 0,01 & 0,01 & 0,05 & 0,00 & 0,00 & 0,04 & 0,01 & 0,04 & 0,04 \\
\hline $\mathrm{K}^{2} \mathrm{O}^{3}$ & 0,00 & 0,01 & 0,02 & 0,01 & 0,01 & 0,00 & 0,00 & 0,00 & 0,00 & 0,00 & 0,01 & 0,00 & 0,00 \\
\hline $\mathrm{CrO}$ & 0,37 & 0,42 & 0,42 & 0,40 & 0,48 & 0,49 & 0,54 & 0,15 & 0,26 & 0,31 & 0,17 & 0,34 & 0,32 \\
\hline Total & 0,00 & 0,00 & 0,00 & 0,00 & 0,00 & 0,00 & 0,00 & 0,00 & 0,00 & 0,00 & 98,82 & 101,76 & 100,16 \\
\hline
\end{tabular}

Número de cátions com base em 6 átomos de oxigênio

\begin{tabular}{|c|c|c|c|c|c|c|c|c|c|c|c|c|c|}
\hline TSi & 1,924 & 1,915 & 1,927 & 1,950 & 1,929 & 1,923 & & 1,960 & 966 & & 1,976 & & \\
\hline TAl & 0,057 & 0,066 & 0,065 & 0,050 & 0,071 & 0,076 & 0,066 & 0,040 & 0,034 & 0,057 & 0,024 & 0,099 & 110 \\
\hline TFe3 & 0,019 & 0,019 & 0,008 &, 000 & 0,000 & 0,001 &, 012 &, 000 & 0,000 & 0,000 &, 000 &, 000 & 0,000 \\
\hline $\mathrm{M} 1 \mathrm{Al}$ & 0,000 & 0,000 & 0,000 & 0,020 & 0,003 & 0,000 &, 000 & 0,055 & 0,078 & &, 074 & 0,015 & 005 \\
\hline M1Ti & 0,003 & 0,002 & 0,002 & ,002 & 0,000 & 0,002 & ,002 &, 002 & 0,002 & 002 &, 000 & 003 &, 001 \\
\hline M1Fe3 & 0,060 & 0,072 & 0,062 & ,017 & 0,056 &, 060 & 63 & 000 & 0,000 & 00 & 000 & 072 & 097 \\
\hline $11 \mathrm{Fe} 2$ & 0,000 & 0,000 & 0,000 & 0,000 & 0,000 & 0,000 & 0,000 & 0,000 & 0,000 & 0,000 & 0,000 &, 000 &, 000 \\
\hline $\mathrm{M} 1 \mathrm{Cr}$ & 0,010 & 011 &, 011 & & & 13 & 14 & & 07 & & & 009 & 009 \\
\hline $\mathrm{M} 1 \mathrm{Mg}$ & 0,927 & 915 & 0,925 & 0,951 & 0,928 & 0,925 & 0,921 & 0,939 & 0,913 & 910 & 0,921 & 0,902 & 888 \\
\hline M1Ni & 0,000 & 000 & 0,000 & 00 & 0,000 & & 000 & & & & & & 000 \\
\hline $\mathrm{M} 2 \mathrm{Mg}$ & 0,923 & 0,927 & 0,897 & 0,852 & 0,898 & 0,899 & 0,901 &, 820 & 0,828 & 819 & 0,827 & 0,897 & 0,920 \\
\hline $12 \mathrm{Fe} 2$ & 0,063 & 0,051 & 0,080 & & 0,085 & 0,088 & & & & & & 092 & 065 \\
\hline $\mathrm{M} 2 \mathrm{Mn}$ & 0,004 & 0,003 & 0,004 & 0,003 & 0,004 & 0,004 & 0,004 & 0,005 & 0,005 & 006 & 004 & 0,003 & 0,005 \\
\hline $\mathrm{M} 2 \mathrm{Ca}$ & 0,009 & 0,016 & 0,016 & & 12 & 0,008 & 17 & & & & & 005 & 008 \\
\hline $\mathrm{M} 2 \mathrm{Na}$ & 0,000 & 0,002 & 0,003 & 0,000 & 0,001 & 0,001 & 0,003 & 0,000 & 0,000 & 0,003 & 0,001 & 0,003 & 0,003 \\
\hline $\mathrm{M} 2 \mathrm{~K}$ & 0,000 & 0,000 & 0,001 & & 0,000 & 0,000 & & & & & & 000 & 000 \\
\hline Sum_cat & 4,000 & 4,000 & 3,999 & 4,000 & 4,000 & 4,000 & 4,000 & 4,000 & 4,000 & 000 & 4,000 & 4,000 & 4,000 \\
\hline $\mathrm{Ca}$ & 0,489 & 0,817 & 0,841 & 1,140 & 0,603 & 0,395 & 0,881 & 0,269 & 0,236 & 274 & 0,136 & ,266 & 0,407 \\
\hline $\mathrm{Mg}$ & 96,030 & 96,321 & 94,798 & 92,457 & 94,757 & 94,786 & 95,026 & 90,730 & 91,016 & 90,631 & 91,075 & 94,707 & 95,873 \\
\hline $\mathrm{Fe} 2 \_\mathrm{Mn}$ & 3,481 & 2,862 & 4,361 & 6,403 & 4,641 & & 4,093 & 9,001 & 8,748 & 95 & 789 & 5,027 & 719 \\
\hline JD1 & 0,000 & 0,000 & 0,000 & 0,022 & 0,055 & 0,000 & 0,000 & 0,000 & 0,000 & 0,137 & 0,058 & 0,131 & 0,133 \\
\hline AE1 & 0,000 & 0,122 & 0,175 & 0,000 & 0,000 & 0,033 & 0,165 &, 000 & 0,000 & 0,000 & 0,000 & 0,000 & 0,000 \\
\hline CFTS 1 & 3,519 & 4,100 & 3,519 & 1,3 & 3,4 & & & ,209 & 0,371 & & 0,241 & 4,076 & 5,323 \\
\hline CTTS 1 & 0,141 & 0,090 & 0,077 & 0,078 & 0,000 & 0,089 & 0,089 & 0,119 & 0,081 & 0,080 & 0,013 & 0,127 & 0,052 \\
\hline CATS 1 & 0,000 & 0,000 & 0,000 & 1,000 & 0,119 & 0,000 & 0,000 & 1,891 & 1,664 & 2,837 & 1,204 & 0,609 & 0,119 \\
\hline WO1 & 0,000 & 0,000 & 0,000 & 0,000 & 0,000 & 0,000 & 0,000 & 0,000 & 0,000 & 0,000 & 000 & 0,000 & 0,000 \\
\hline EN1 & 93,151 & 93,097 & 92,176 & 91,352 & 92,064 & 91,763 & 92,236 & 89,173 & 89,538 & 87,970 & 90,024 & 90,428 & 91,101 \\
\hline FS1 & 3,189 & 2,592 & 4,053 & 6,166 & 4,306 & 4,450 & 3,786 & 8,608 & 8,346 & & 8,460 & 4,628 & 3,272 \\
\hline $\mathrm{Q}$ & 1,924 & 1,909 & 1,918 & 1,947 & 1,923 & 1,920 & 1,914 & 1,934 & 1,908 & 1,902 & 1,916 & 1,896 & 1,880 \\
\hline $\mathrm{J}$ & 0,000 & 0,004 & 0,005 & 0,000 & 0,001 & 0,001 & 0,007 & 0,000 & 0,000 & 0,005 & 0,001 & 0,005 & 0,005 \\
\hline WO & 0,470 & 0,780 & 0,812 & 1,130 & 0,586 & 0,383 & 0,848 & 0,269 & 0,236 & 0,274 & 0,136 & 0,256 & 0,388 \\
\hline EN & 92,241 & 91,952 & 91,486 & 91,680 & 92,094 & 91,849 & 91,483 & 90,730 & 91,016 & 90,631 & 91,075 & 91,246 & 91,182 \\
\hline FS & 7,290 & 7,268 & 7,702 & 7,190 & 7,320 & 7,768 & 7,668 & 9,001 & 8,748 & 9,095 & 8,789 & 8,498 & 8,430 \\
\hline WEF & 100,000 & 99,794 & 99,730 & 100,000 & 99,932 & 99,932 & 99,662 & 100,000 & 100,000 & 99,718 & 99,930 & 99,726 & 99,720 \\
\hline JD & 0,000 & 0,000 & 0,000 & 0,000 & 0,004 & 0,000 & 0,000 & 0,000 & 0,000 & 0,282 & 0,070 & 0,047 & 0,014 \\
\hline $\mathrm{AE}$ & 0,000 & 0,206 & 0,270 & 0,000 & 0,064 & 0,068 & 0,338 & 0,000 & 0,000 & 0,000 & 0,000 & 0,228 & 0,266 \\
\hline
\end{tabular}




\section{Tabela 6- Continuação.}

\begin{tabular}{|c|c|c|c|c|c|c|c|c|c|c|c|c|c|}
\hline & \multicolumn{4}{|c|}{ Harzburgito com bolsões de clinopiroxênio } & \multicolumn{7}{|c|}{ Lherzolito com espinélio } & \multicolumn{2}{|c|}{ Harzburgito } \\
\hline 2 & $12 / 1$ & $12 / 2$ & $12 / 3$ & $12 / 4$ & $13 \mathrm{a} / 1$ & $13 \mathrm{a} / 2$ & $13 \mathrm{a} / 3$ & $13 \mathrm{a} / 4$ & $13 \mathrm{a} / 5$ & $13 \mathrm{a} / 6$ & $13 \mathrm{a} / 7$ & $13 \mathrm{~b} / 1$ & $13 \mathrm{~b} / 2$ \\
\hline $\mathrm{SiO}_{3}^{2}$ & 57,88 & 57,18 & 58,69 & 57,66 & 56,52 & 51,29 & 54,51 & 56,87 & 55,33 & 56,32 & 56,89 & 56,85 & 56,23 \\
\hline $\mathrm{TiO}^{2}$ & 0,00 & 0,00 & 0,01 & 0,04 & 0,06 & 0,04 & 0,00 & 0,12 & 0,01 & 0,05 & 0,00 & 0,04 & 0,13 \\
\hline $\mathrm{Al} \mathrm{O}$ & 0,11 & 1,00 & 0,26 & 1,24 & 2,02 & 7,08 & 3,83 & 1,84 & 3,30 & 2,82 & 1,52 & 2,60 & 2,14 \\
\hline $\mathrm{FeO}$ & 4,78 & 4,60 & 4,94 & 4,92 & 5,52 & 6,13 & 5,65 & 5,15 & 5,85 & 5,19 & 5,42 & 5,44 & 5,29 \\
\hline $\mathrm{MnO}$ & 0,14 & 0,13 & 0,10 & 0,12 & 0,17 & 0,16 & 0,15 & 0,16 & 0,15 & 0,12 & 0,14 & 0,11 & 0,16 \\
\hline $\mathrm{MgO}$ & 37,43 & 37,08 & 37,25 & 36,47 & 36,22 & 34,50 & 35,85 & 37,07 & 35,90 & 35,23 & 36,00 & 35,88 & 35,84 \\
\hline $\mathrm{CaO}_{2}^{2}$ & 0,27 & 0,20 & 0,17 & 0,16 & 0,14 & 0,12 & 0,16 & 0,10 & 0,20 & 1,25 & 0,10 & 0,21 & 0,56 \\
\hline $\mathrm{Na}^{2} \mathrm{O}$ & 0,04 & 0,04 & 0,01 & 0,01 & 0,02 & 0,01 & 0,03 & 0,03 & 0,01 & 0,06 & 0,04 & 0,00 & 0,02 \\
\hline $\mathrm{K} \mathrm{O}^{2} \mathrm{O}^{3}$ & 0,00 & 0,00 & 0,00 & 0,01 & 0,01 & 0,01 & 0,00 & 0,00 & 0,01 & 0,00 & 0,47 & 0,00 & 0,00 \\
\hline $\mathrm{CrO}$ & 0,14 & 0,31 & 0,25 & 0,27 & 0,27 & 2,65 & 1,00 & 0,19 & 0,80 & 0,53 & 0,15 & 0,58 & 0,30 \\
\hline Total & 100,78 & 100,55 & 101,66 & 100,90 & 100,95 & 101,98 & 101,18 & 101,55 & 101,55 & 101,56 & 100,73 & 101,71 & 100,68 \\
\hline \multicolumn{14}{|c|}{ Número de cátions com base em 6 átomos de oxigênio } \\
\hline $\mathrm{TSi}$ & 1,955 & 1,936 & 1,970 & 1,952 & 1,914 & 1,730 & 1,843 & 1,909 & 1,865 & 1,901 & 1,930 & 1,915 & 1,911 \\
\hline TAl & 0,004 & 0,040 & 0,010 & 0,048 & 0,081 & 0,270 & 0,152 & 0,073 & 0,131 & 0,099 & 0,061 & 0,085 & 0,086 \\
\hline TFe3 & 0,040 & 0,024 & 0,019 & 0,000 & 0,005 & 0,000 & 0,005 & 0,018 & 0,003 & 0,000 & 0,009 & 0,000 & 0,004 \\
\hline M1Al & 0,000 & 0,000 & 0,000 & 0,002 & 0,000 & 0,011 & 0,000 & 0,000 & 0,000 & 0,013 & 0,000 & 0,018 & 0,000 \\
\hline M1Ti & 0,000 & 0,000 & 0,000 & 0,001 & 0,002 & 0,001 & 0,000 & 0,003 & 0,000 & 0,001 & 0,000 & 0,001 & 0,003 \\
\hline M1Fe3 & 0,043 & 0,058 & 0,023 & 0,038 & 0,077 & 0,000 & 0,132 & 0,081 & 0,113 & 0,073 & 0,089 & 0,049 & 0,076 \\
\hline $\mathrm{M} 1 \mathrm{Fe} 2$ & 0,000 & 0,000 & 0,000 & 0,000 & 0,000 & 0,000 & 0,000 & 0,000 & 0,000 & 0,000 & 0,000 & 0,000 & 0,000 \\
\hline $\mathrm{M} 1 \mathrm{Cr}$ & 0,004 & 0,008 & 0,007 & 0,007 & 0,007 & 0,071 & 0,027 & 0,005 & 0,021 & 0,014 & 0,004 & 0,015 & 0,008 \\
\hline $\mathrm{M} 1 \mathrm{Mg}$ & 0,953 & 0,934 & 0,970 & 0,952 & 0,914 & 0,917 & 0,841 & 0,911 & 0,865 & 0,899 & 0,907 & 0,916 & 0,913 \\
\hline $\mathrm{M} 1 \mathrm{Ni}$ & 0,000 & 0,000 & 0,000 & 0,000 & 0,000 & 0,000 & 0,000 & 0,000 & 0,000 & 0,000 & 0,000 & 0,000 & 0,000 \\
\hline $\mathrm{M} 2 \mathrm{Mg}$ & 0,932 & 0,938 & 0,894 & 0,888 & 0,914 & 0,817 & 0,965 & 0,945 & 0,939 & 0,874 & 0,913 & 0,885 & 0,903 \\
\hline $\mathrm{M} 2 \mathrm{Fe} 2$ & 0,051 & 0,048 & 0,096 & 0,101 & 0,074 & 0,173 & 0,023 & 0,045 & 0,048 & 0,073 & 0,056 & 0,104 & 0,071 \\
\hline M2Mn & 0,004 & 0,004 & 0,003 & 0,003 & 0,005 & 0,005 & 0,004 & 0,005 & 0,004 & 0,003 & 0,004 & 0,003 & 0,005 \\
\hline $\mathrm{M} 2 \mathrm{Ca}$ & 0,010 & 0,007 & 0,006 & 0,006 & 0,005 & 0,004 & 0,006 & 0,004 & 0,007 & 0,045 & 0,004 & 0,008 & 0,020 \\
\hline M2Na & 0,003 & 0,003 & 0,001 & 0,001 & 0,001 & 0,001 & 0,002 & 0,002 & 0,001 & 0,004 & 0,003 & 0,000 & 0,001 \\
\hline $\mathrm{M} 2 \mathrm{~K}$ & 0,000 & 0,000 & 0,000 & 0,000 & 0,000 & 0,000 & 0,000 & 0,000 & 0,000 & 0,000 & 0,020 & 0,000 & 0,000 \\
\hline Sum_cat & 4,000 & 4,000 & 4,000 & 4,000 & 4,000 & 4,000 & 4,000 & 4,000 & 4,000 & 4,000 & 3,980 & 4,000 & 4,000 \\
\hline $\mathrm{Ca}$ & 0,501 & 0,376 & 0,311 & 0,297 & 0,266 & 0,226 & 0,315 & 0,188 & 0,388 & 2,386 & 0,193 & 0,395 & 1,067 \\
\hline $\mathrm{Mg}$ & 96,663 & 96,929 & 94,666 & 94,339 & 95,619 & 90,513 & 98,226 & 97,207 & 96,802 & 93,558 & 96,627 & 94,020 & 94,971 \\
\hline Fe2_Mn & 2,835 & 2,695 & 5,024 & 5,363 & 4,116 & 9,261 & 1,459 & 2,605 & 2,811 & 4,056 & 3,181 & 5,584 & 3,963 \\
\hline JD1 & 0,000 & 0,000 & 0,000 & 0,055 & 0,000 & 0,054 & 0,000 & 0,000 & 0,000 & 0,202 & 0,000 & 0,000 & 0,000 \\
\hline $\mathrm{AE} 1$ & 0,132 & 0,132 & 0,033 & 0,000 & 0,088 & 0,000 & 0,099 & 0,098 & 0,055 & 0,000 & 1,167 & 0,000 & 0,067 \\
\hline CFTS1 & 2,249 & 3,205 & 1,465 & 2,277 & 4,155 & 3,547 & 7,893 & 4,245 & 6,720 & 4,478 & 3,541 & 3,257 & 4,171 \\
\hline CTTS1 & 0,000 & 0,000 & 0,013 & 0,051 & 0,077 & 0,051 & 0,000 & 0,152 & 0,013 & 0,065 & 0,000 & 0,051 & 0,168 \\
\hline CATS1 & 0,000 & 0,000 & 0,000 & 0,021 & 0,000 & 0,497 & 0,000 & 0,000 & 0,000 & 0,463 & 0,000 & 0,904 & 0,000 \\
\hline WO1 & 0,000 & 0,000 & 0,000 & 0,000 & 0,000 & 0,000 & 0,000 & 0,000 & 0,000 & 0,000 & 0,000 & 0,000 & 0,000 \\
\hline EN1 & 95,033 & 94,230 & 93,662 & 92,509 & 91,967 & 87,163 & 90,874 & 93,234 & 90,792 & 91,022 & 92,454 & 90,567 & 91,989 \\
\hline FS1 & 2,586 & 2,433 & 4,828 & 5,086 & 3,713 & 8,688 & 1,134 & 2,270 & 2,420 & 3,770 & 2,839 & 5,221 & 3,605 \\
\hline $\mathrm{Q}$ & 1,946 & 1,927 & 1,966 & 1,948 & 1,907 & 1,912 & 1,835 & 1,904 & 1,860 & 1,891 & 1,880 & 1,913 & 1,907 \\
\hline $\mathrm{J}$ & 0,005 & 0,005 & 0,001 & 0,001 & 0,003 & 0,001 & 0,004 & 0,004 & 0,001 & 0,008 & 0,005 & 0,000 & 0,003 \\
\hline WO & 0,481 & 0,360 & 0,304 & 0,292 & 0,255 & 0,226 & 0,293 & 0,179 & 0,365 & 2,297 & 0,183 & 0,386 & 1,024 \\
\hline $\mathrm{EN}$ & 92,683 & 92,983 & 92,661 & 92,532 & 91,664 & 90,513 & 91,408 & 92,394 & 91,092 & 90,084 & 91,856 & 91,659 & 91,194 \\
\hline FS & 6,837 & 6,656 & 7,035 & 7,176 & 8,081 & 9,261 & 8,299 & 7,427 & 8,543 & 7,619 & 7,961 & 7,956 & 7,782 \\
\hline WEF & 99,732 & 99,729 & 99,934 & 99,933 & 99,863 & 99,932 & 99,787 & 99,796 & 99,930 & 99,587 & 99,721 & 100,000 & 99,862 \\
\hline $\mathrm{JD}$ & 0,000 & 0,000 & 0,000 & 0,003 & 0,000 & 0,068 & 0,000 & 0,000 & 0,000 & 0,062 & 0,000 & 0,000 & 0,000 \\
\hline $\mathrm{AE}$ & 0,268 & 0,271 & 0,066 & 0,065 & 0,137 & 0,000 & 0,213 & 0,204 & 0,070 & 0,351 & 0,279 & 0,000 & 0,138 \\
\hline
\end{tabular}


Tabela 6- Continuação.

Lherzolito com espinélio e textura grossa

\begin{tabular}{|c|c|c|c|c|c|c|c|c|}
\hline 2 & $14 \mathrm{a} / 1$ & $14 \mathrm{a} / 2$ & $14 \mathrm{a} / 3$ & $14 \mathrm{a} / 4$ & $14 \mathrm{a} / 5$ & $14 \mathrm{a} / 6$ & $14 \mathrm{a} / 7$ & $14 \mathrm{a} / 8$ \\
\hline $\mathrm{SiO}_{3}^{2}$ & 56,39 & 55,31 & 51,85 & 56,32 & 55,51 & 56,46 & 56,33 & 56,02 \\
\hline $\mathrm{TiO}^{3}$ & 0,13 & 0,12 & 0,00 & 0,00 & 0,02 & 0,02 & 0,00 & 0,16 \\
\hline $\mathrm{Al} \mathrm{O}$ & 3,02 & 3,63 & 8,62 & 2,59 & 3,06 & 2,98 & 2,94 & 2,57 \\
\hline $\mathrm{FeO}$ & 5,93 & 5,52 & 6,23 & 5,70 & 5,62 & 5,75 & 5,72 & 5,69 \\
\hline $\mathrm{MnO}$ & 0,14 & 0,16 & 0,15 & 0,17 & 0,13 & 0,16 & 0,12 & 0,13 \\
\hline $\mathrm{MgO}$ & 33,52 & 33,06 & 31,88 & 33,79 & 33,03 & 32,95 & 33,38 & 35,74 \\
\hline $\mathrm{CaO}_{2}^{a}$ & 0,11 & 0,14 & 0,08 & 0,35 & 0,34 & 0,43 & 0,15 & 0,18 \\
\hline $\mathrm{Na}_{2}^{2} \mathrm{O}_{3}$ & 0,04 & 0,00 & 0,01 & 0,00 & 0,05 & 0,06 & 0,01 & 0,05 \\
\hline $\mathrm{K}^{2} \mathrm{O}^{3}$ & 0,00 & 0,00 & 0,00 & 0,00 & 0,00 & 0,00 & 0,02 & 0,02 \\
\hline $\mathrm{CrO}$ & 0,32 & 0,44 & 1,17 & 0,26 & 0,39 & 0,33 & 0,34 & 0,22 \\
\hline Total & 99,60 & 98,38 & 99,98 & 99,17 & 98,15 & 99,13 & 98,98 & 100,77 \\
\hline
\end{tabular}

Número de cátions com base em 6 átomos de oxigênio
Harzburgito com flogopita

$\begin{array}{cccccc}20 \mathrm{~b} / 1 & 20 \mathrm{~b} / 2 & 20 \mathrm{~b} / 3 & 20 \mathrm{~b} / 4 & 20 \mathrm{~b} / 5 & 20 \mathrm{~b} / 6 \\ 55,58 & 57,61 & 57,48 & 57,50 & 57,78 & 57,63 \\ 0,05 & 0,26 & 0,04 & 0,00 & 0,00 & 0,00 \\ 1,23 & 1,21 & 1,46 & 1,63 & 1,27 & 1,44 \\ 4,08 & 4,21 & 4,13 & 4,34 & 4,31 & 4,13 \\ 0,11 & 0,09 & 0,08 & 0,13 & 0,09 & 0,11 \\ 35,57 & 35,42 & 35,54 & 35,41 & 36,03 & 35,68 \\ 0,29 & 0,67 & 0,48 & 0,38 & 0,39 & 0,32 \\ 0,08 & 0,11 & 0,10 & 0,10 & 0,12 & 0,08 \\ 0,00 & 0,00 & 0,00 & 0,00 & 0,00 & 0,02 \\ 0,40 & 0,34 & 0,36 & 0,46 & 0,34 & 0,43 \\ 97,38 & 99,91 & 99,68 & 99,95 & 100,33 & 99,85\end{array}$

\begin{tabular}{|c|c|c|c|c|c|c|c|c|c|c|c|c|c|c|}
\hline TSi & & & & & & & & & & & & & & \\
\hline TAl & 048 & 0,063 & 0,210 & 0,045 & & 0,034 & & & & & & & & 0,029 \\
\hline TFe3 & 0,000 & 000 & 000 & 000 & 00 & 00 & & & & & & & &, 000 \\
\hline $\mathrm{M} 1 \mathrm{Al}$ & ,075 & & & & & & & & & & & & &, 030 \\
\hline M1Ti & 003 & & & & & & & & & & & & &, 000 \\
\hline M1Fe3 & 000 & 000 & & & & & & & & & & & &, 000 \\
\hline $11 \mathrm{Fe} 2$ & 000 & & & & & & & & & & & & & 000 \\
\hline $11 \mathrm{Cr}$ & 009 & & 32 & & & & & & & & & & & 012 \\
\hline $\mathrm{M} 1 \mathrm{Mg}$ & 0,913 & 0,8 & 90 & & & & & & & & & & & 959 \\
\hline $\mathrm{M} 1 \mathrm{Ni}$ &, 000 & & & & & & & & & & & & & 0,000 \\
\hline $\mathrm{M} 2 \mathrm{Mg}$ & 0,817 & 28 & 850 & 17 & 5 & 08 & & & & & & 51 & & ,861 \\
\hline $2 \mathrm{Fe} 2$ & 0,172 & & & & & & & & & & & & & 118 \\
\hline $2 \mathrm{Mn}$ & 0,004 & 05 & 0,004 & & & & & & & & & & & 0,003 \\
\hline $\mathrm{M} 2 \mathrm{Ca}$ & 0,004 & & & & & & & & & & & & & 12 \\
\hline $\mathrm{M} 2 \mathrm{Na}$ & 0,00 & & & & & & & & & & & & & 005 \\
\hline M2K & 0,000 & 0 & 00 & 00 & 0 & & & & & & & 00 & & 0,001 \\
\hline um_cat & 000 & 4,000 & 4,000 & & & & & & & & & & & 999 \\
\hline $\mathrm{Ca}$ & 0,214 & 0,277 & 0,165 & & & & & & & & & 15 & & 0,601 \\
\hline $\mathrm{Mg}$ & 90,582 & 90,9 & & & 90,4 & & & & & & & & & 93, \\
\hline e2_Mn & 9,205 & & & & & & & & & & & & & 6,214 \\
\hline JD1 & 0,137 & 000 & 0,0 & & & & & & & & & & & 0,312 \\
\hline AE1 & 000 & & 00 & & & & & & & & & 00 & & 0,000 \\
\hline CFTS1 & 0,446 & 620 & 3,514 & 362 & 0,552 & 0,471 & & & & 0,468 & & 29 & 08 & 0,587 \\
\hline TTS 1 & 0,173 & & 0,000 & & 0,027 & 0,027 & & & & & & 00 & & 0,000 \\
\hline CATS1 & 2,265 & 3,041 & 6,992 & 2,290 & 2,596 & 1,752 & 2,013 & 37 & 000 & 708 & 16 & 1,333 & 429 & 1,179 \\
\hline WO1 & 0,000 & & & & & & & & & & & & & 0,000 \\
\hline EN1 & 88,224 & 87,941 & 82,346 & 88,932 & 88,230 & 88,842 & 88,883 & 1,113 & 93,636 & 91,979 & 92,004 & 91,416 & 92,501 & 91,951 \\
\hline FS1 & & & & & & & & & & & & & & 5,971 \\
\hline $\mathrm{Q}$ & 1,906 & & 1,785 & & 1,906 & & & & & & & 1,944 & & 1,950 \\
\hline $\mathrm{J}$ & & & & & & & & & & & & & & 0,011 \\
\hline WO & 0,214 & & 0,162 & & & & & & & & & & ,723 & 0,601 \\
\hline EN & 90,582 & & & & & & & & & & 92,922 & & 92,910 & 93,185 \\
\hline FS & 9,205 & & 0,080 & & & & & & & & 6,176 & 6,568 & 6,367 & 6,214 \\
\hline WEF & 99,720 & 100,000 & 99,925 & 100,000 & 99,645 & & & & & & 99,324 & 99,323 & 99,195 & 99,459 \\
\hline JD & & & 0,059 & & 0,355 & & & 0,019 & & & 0,676 & 0,677 & 0,399 & 0,541 \\
\hline $\mathrm{AE}$ & 0,000 & 0,000 & 0,016 & 0,000 & 0,000 & 0,000 & 0,000 & 0,326 & 0,558 & 0,000 & 0,000 & 0,000 & 0,407 & 0,000 \\
\hline
\end{tabular}


Tabela 6- Continuação.

\begin{tabular}{|c|c|c|c|c|c|c|c|c|c|c|c|c|}
\hline \multicolumn{7}{|c|}{ Dunito com cromita e textura granoblástica } & \multicolumn{6}{|c|}{ Mica piroxenito } \\
\hline 2 & $24 \mathrm{a} / 1$ & $24 \mathrm{a} / 2$ & $24 \mathrm{a} / 3$ & $24 \mathrm{a} / 4$ & $24 \mathrm{a} / 5$ & $24 \mathrm{a} / 6$ & $24 \mathrm{~b} / 1$ & $24 b / 2$ & $24 b / 3$ & $24 \mathrm{~b} / 4$ & $24 \mathrm{~b} / 5$ & $24 \mathrm{~b} / 6$ \\
\hline $\mathrm{SiO}_{3}^{2}$ & 57,14 & 57,64 & 57,67 & 56,61 & 57,67 & 57,72 & 57,49 & 57,68 & 54,20 & 58,26 & 57,43 & 57,82 \\
\hline $\mathrm{TiO}^{2}$ & 0,13 & 0,10 & 0,11 & 0,16 & 0,12 & 0,15 & 0,12 & 0,28 & 0,17 & 0,19 & 0,08 & 0,16 \\
\hline $\mathrm{Al} \mathrm{O}$ & 1,62 & 1,40 & 1,64 & 1,62 & 1,70 & 1,67 & 0,27 & 0,28 & 0,31 & 0,21 & 0,26 & 0,25 \\
\hline $\mathrm{FeO}$ & 5,03 & 5,35 & 5,11 & 5,05 & 5,43 & 5,04 & 8,85 & 9,06 & 8,53 & 9,32 & 8,70 & 9,42 \\
\hline $\mathrm{MnO}$ & 0,12 & 0,13 & 0,13 & 0,11 & 0,13 & 0,14 & 0,18 & 0,23 & 0,17 & 0,17 & 0,14 & 0,19 \\
\hline $\mathrm{MgO}$ & 35,23 & 35,92 & 35,61 & 35,76 & 35,46 & 35,26 & 33,76 & 33,26 & 31,71 & 32,99 & 33,24 & 32,75 \\
\hline $\mathrm{CaO}_{2}^{2}$ & 0,40 & 0,32 & 0,46 & 0,33 & 0,48 & 0,55 & 0,54 & 0,72 & 1,43 & 0,68 & 0,49 & 0,60 \\
\hline $\mathrm{Na}_{2}^{2} \mathrm{O}_{3}$ & 0,03 & 0,03 & 0,07 & 0,02 & 0,04 & 0,04 & 0,08 & 0,09 & 0,38 & 0,09 & 0,12 & 0,09 \\
\hline $\mathrm{K}^{2} \mathrm{O}^{3}$ & 0,00 & 0,00 & 0,01 & 0,00 & 0,00 & 0,00 & 0,00 & 0,01 & 1,15 & 0,01 & 0,02 & 0,01 \\
\hline $\mathrm{CrO}$ & 0,43 & 0,27 & 0,48 & 0,47 & 0,41 & 0,46 & 0,11 & 0,02 & 0,07 & 0,06 & 0,14 & 0,10 \\
\hline Total & 100,12 & 101,15 & 101,29 & 100,13 & 101,44 & 101,01 & 101,40 & 101,61 & 98,12 & 101,99 & 100,62 & 101,37 \\
\hline
\end{tabular}

Número de cátions com base em 6 átomos de oxigênio

\begin{tabular}{|c|c|c|c|c|c|c|c|c|c|c|c|c|}
\hline TSi & 1,957 & 1,952 & 1,952 & 1,935 & 1,952 & 1,961 & 1,972 & 1,980 & 1,918 & 1,996 & 1,987 & 1,994 \\
\hline TAl & 0,043 & 0,048 & 0,048 & 0,065 & 0,048 & 0,039 & 0,011 & 0,011 & 0,013 & 0,004 & 0,011 & 0,006 \\
\hline $\mathrm{TFe} 3$ & 0,000 & 0,000 & 0,000 & 0,000 & 0,000 & 0,000 & 0,017 & 0,009 & 0,069 & 0,000 & 0,003 & 0,000 \\
\hline M1Al & 0,022 & 0,008 & 0,017 & 0,000 & 0,019 & 0,028 & 0,000 & 0,000 & 0,000 & 0,005 & 0,000 & 0,004 \\
\hline M1Ti & 0,003 & 0,003 & 0,003 & 0,004 & 0,003 & 0,004 & 0,003 & 0,007 & 0,005 & 0,005 & 0,002 & 0,004 \\
\hline M1Fe3 & 0,004 & 0,030 & 0,017 & 0,045 & 0,014 & 0,000 & 0,024 & 0,012 & 0,149 & 0,000 & 0,014 & 0,000 \\
\hline M1Fe2 & 0,000 & 0,000 & 0,000 & 0,000 & 0,000 & 0,000 & 0,000 & 0,000 & 0,000 & 0,000 & 0,000 & 0,000 \\
\hline $\mathrm{M} 1 \mathrm{Cr}$ & 0,012 & 0,007 & 0,013 & 0,013 & 0,011 & 0,012 & 0,003 & 0,001 & 0,002 & 0,002 & 0,004 & 0,003 \\
\hline $\mathrm{M} 1 \mathrm{Mg}$ & 0,958 & 0,953 & 0,950 & 0,938 & 0,952 & 0,956 & 0,970 & 0,980 & 0,845 & 0,989 & 0,980 & 0,989 \\
\hline $\mathrm{M} 1 \mathrm{Ni}$ & 0,000 & 0,000 & 0,000 & 0,000 & 0,000 & 0,000 & 0,000 & 0,000 & 0,000 & 0,000 & 0,000 & 0,000 \\
\hline $\mathrm{M} 2 \mathrm{Mg}$ & 0,840 & 0,861 & 0,847 & 0,884 & 0,837 & 0,830 & 0,757 & 0,721 & 0,828 & 0,697 & 0,734 & 0,694 \\
\hline $\mathrm{M} 2 \mathrm{Fe} 2$ & 0,140 & 0,122 & 0,128 & 0,099 & 0,140 & 0,143 & 0,213 & 0,239 & 0,034 & 0,267 & 0,234 & 0,272 \\
\hline M2Mn & 0,003 & 0,004 & 0,004 & 0,003 & 0,004 & 0,004 & 0,005 & 0,007 & 0,005 & 0,005 & 0,004 & 0,006 \\
\hline $\mathrm{M} 2 \mathrm{Ca}$ & 0,015 & 0,012 & 0,017 & 0,012 & 0,017 & 0,020 & 0,020 & 0,026 & 0,054 & 0,025 & 0,018 & 0,022 \\
\hline $\mathrm{M} 2 \mathrm{Na}$ & 0,002 & 0,002 & 0,005 & 0,001 & 0,003 & 0,003 & 0,005 & 0,006 & 0,026 & 0,006 & 0,008 & 0,006 \\
\hline $\mathrm{M} 2 \mathrm{~K}$ & 0,000 & 0,000 & 0,000 & 0,000 & 0,000 & 0,000 & 0,000 & 0,000 & 0,052 & 0,000 & 0,001 & 0,000 \\
\hline Sum_cat & 4,000 & 4,000 & 4,000 & 4,000 & 4,000 & 4,000 & 4,000 & 4,000 & 3,948 & 4,000 & 3,999 & 4,000 \\
\hline $\mathrm{Ca}$ & 0,750 & 0,595 & 0,858 & 0,624 & 0,893 & 1,025 & 1,010 & 1,341 & 3,069 & 1,259 & 0,921 & 1,118 \\
\hline $\mathrm{Mg}$ & 91,933 & 92,959 & 92,384 & 94,088 & 91,756 & 91,437 & 87,877 & 86,206 & 94,694 & 85,018 & 86,974 & 84,903 \\
\hline Fe2_Mn & 7,316 & 6,446 & 6,758 & 5,288 & 7,351 & 7,538 & 11,112 & 12,453 & 2,237 & 13,723 & 12,105 & 13,980 \\
\hline JD1 & 0,101 & 0,099 & 0,255 & 0,006 & 0,133 & 0,134 & 0,000 & 0,000 & 0,000 & 0,244 & 0,000 & 0,194 \\
\hline AE1 & 0,000 & 0,000 & 0,000 & 0,060 & 0,000 & 0,000 & 0,270 & 0,326 & 4,187 & 0,080 & 0,452 & 0,131 \\
\hline CFTS1 & 0,810 & 1,852 & 1,507 & 2,855 & 1,267 & 0,625 & 1,095 & 0,300 & 3,914 & 0,002 & 0,468 & 0,006 \\
\hline CTTS1 & 0,169 & 0,128 & 0,142 & 0,207 & 0,155 & 0,194 & 0,157 & 0,366 & 0,243 & 0,183 & 0,105 & 0,209 \\
\hline CATS1 & 1,020 & 0,299 & 0,627 & 0,000 & 0,854 & 1,283 & 0,000 & 0,000 & 0,000 & 0,000 & 0,000 & 0,000 \\
\hline WO1 & 0,000 & 0,000 & 0,000 & 0,000 & 0,000 & 0,000 & 0,000 & 0,675 & 0,000 & 1,073 & 0,346 & 0,902 \\
\hline EN1 & 90,847 & 91,467 & 91,001 & 91,869 & 90,528 & 90,506 & 87,658 & 86,217 & 89,808 & 84,954 & 86,761 & 84,864 \\
\hline FS1 & 7,054 & 6,154 & 6,468 & 5,003 & 7,064 & 7,257 & 10,819 & 12,116 & 1,848 & 13,464 & 11,868 & 13,693 \\
\hline $\mathrm{Q}$ & 1,953 & 1,947 & 1,941 & 1,933 & 1,946 & 1,949 & 1,959 & 1,967 & 1,761 & 1,977 & 1,967 & 1,977 \\
\hline $\mathrm{J}$ & 0,004 & 0,004 & 0,009 & 0,003 & 0,005 & 0,005 & 0,011 & 0,012 & 0,052 & 0,012 & 0,016 & 0,012 \\
\hline WO & 0,749 & 0,586 & 0,850 & 0,610 & 0,886 & 1,025 & 0,990 & 1,327 & 2,732 & 1,259 & 0,913 & 1,118 \\
\hline EN & 91,727 & 91,574 & 91,587 & 91,945 & 91,098 & 91,437 & 86,089 & 85,302 & 84,291 & 85,018 & 86,221 & 84,903 \\
\hline FS & 7,524 & 7,840 & 7,563 & 7,445 & 8,015 & 7,538 & 12,921 & 13,370 & 12,977 & 13,723 & 12,866 & 13,980 \\
\hline WEF & 99,797 & 99,798 & 99,530 & 99,863 & 99,731 & 99,731 & 99,461 & 99,397 & 97,133 & 99,400 & 99,190 & 99,397 \\
\hline JD & 0,170 & 0,043 & 0,238 & 0,000 & 0,156 & 0,269 & 0,000 & 0,000 & 0,000 & 0,600 & 0,000 & 0,603 \\
\hline $\mathrm{AE}$ & 0,034 & 0,159 & 0,232 & 0,136 & 0,113 & 0,000 & 0,539 & 0,603 & 2,867 & 0,000 & 0,810 & 0,000 \\
\hline
\end{tabular}



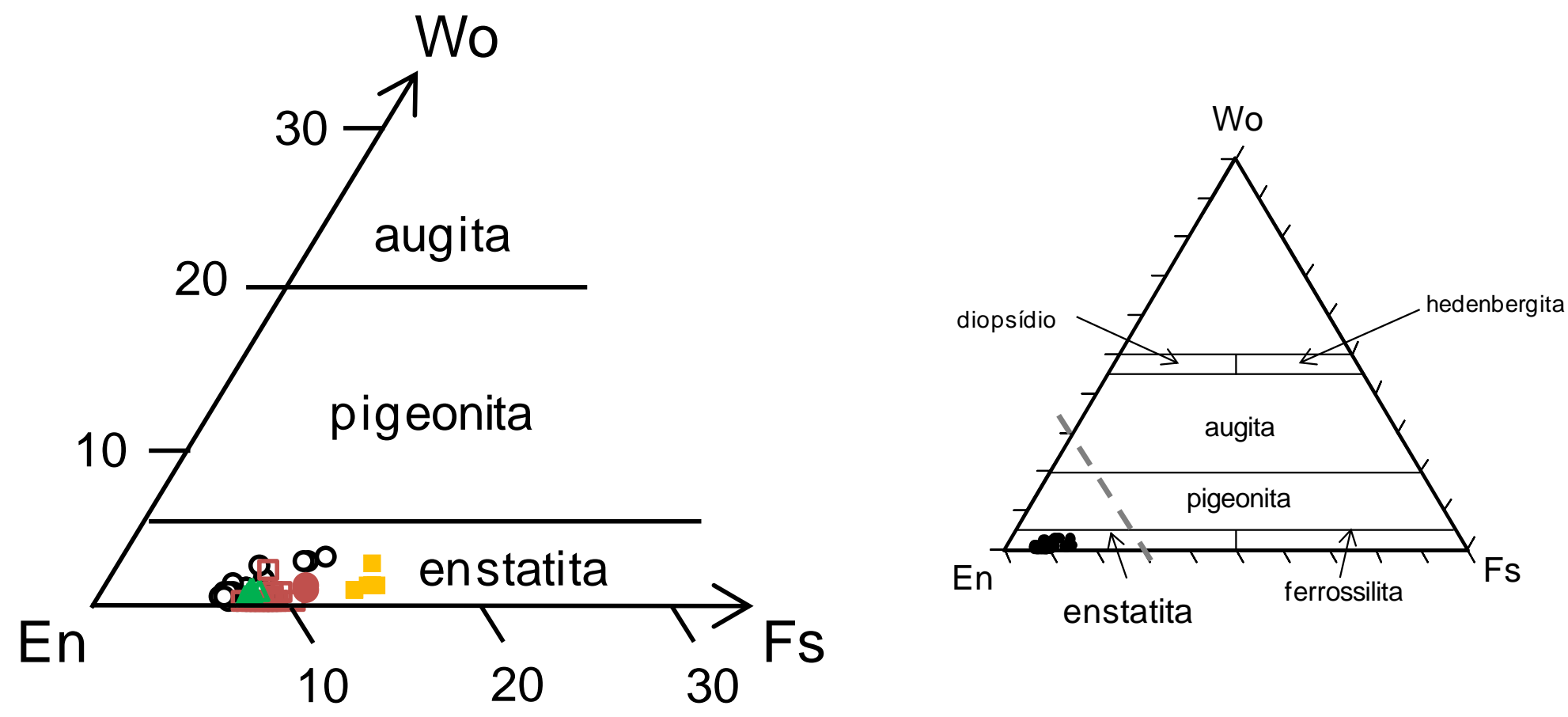

- Harzburgitos $\square$ Lherzolitos $\Delta$ Dunitos $\backsim$ Mica piroxenitos $\bullet$ Flogopita dunito

Figura 24- Composição química de ortopiroxênio de xenólitos do Kimberlito Indaiá. As amostras estudadas projetam-se no campo da enstatita, próximo ao vértice do $\mathrm{Mg}$. 


\subsection{Clinopiroxênio}

O clinopiroxênio não é abundante nas amostras dos xenólitos estudados, porém ocorre na maioria delas e apresenta grande variação composicional, como é apresentado na Tabela 7.

Em geral a variação no teor das moléculas wollastonita (Wo), enstatita (En) e ferrossilita (Fs) é de respectivamente 41-51\%, 46-52\% e 0,2-8\%. Nos harzburgitos a variação é de 41-51\% de Wo, 46-52\% de En e 2-8\% de Fs; 0,3-4,2\% de $\mathrm{Al}_{2} \mathrm{O}_{3}$ e 0,1-3,5\% de $\mathrm{Cr}_{2} \mathrm{O}_{3}$. Nos lherzolitos, Wo, En e Fs têm variações de respectivamente 48-51\%, 46-48\% e 0,2-4\%; 3-7\% de $\mathrm{Al}_{2} \mathrm{O}_{3}$ e 0,91,4\% de $\mathrm{Cr}_{2} \mathrm{O}_{3}$. No flogopita dunito representado pelas amostras In1/2, os valores de Wo, En e Fs são respectivamente $44 \%$, 48-51\% e 4-5\%, com $\mathrm{Al}_{2} \mathrm{O}_{3}$ 0,2-0,7\% e $\mathrm{Cr}_{2} \mathrm{O}_{3}$ 0,1-1,8\%. Para o xenólito polimítico da amostra In1/24b Wo, En e Fs são respectivamente 44-45\%, 48-49\% e 7\%; $\mathrm{Al}_{2} \mathrm{O}_{3} 0,2-0,3 \%$ e $\mathrm{Cr}_{2} \mathrm{O}_{3} 0,4-0,5 \%$.

Os clinopiroxênios estudados correspondem a diopísio ou augita, segundo a classificação de Morimoto et al. (1988), como apresenta a Figura 24. Ocorrem importantes variações na porporção de Wo, onde os maiores valores são observados em clinopiroxênios de lherzolitos, seguidos pelos de harzburgitos e dunitos. O xenólito polimítico apresenta Wo similar aos dunitos, porém a proporção de Fs é maior. A grande maioria dos dados projetados é compatível ou próxima ao campo de lherzolitos granulares definido por Nixon (1973a), como mostra a Figura 25.

A Figura 26A mostra a ampla variação de $\mathrm{Na}_{2} \mathrm{O}$ nos exemplares de clinopiroxênios de harzburgitos, onde é possível notar até uma correlação negativa entre $\mathrm{Na}_{2} \mathrm{O}$ e \#Mg. $\mathrm{O}$ clinopiroxênio de lherzolito tem quantidades intermediárias de $\mathrm{Na}_{2} \mathrm{O}$; o do flogopita dunito e do xenólito polimítico são projetados no campo de piroxenitos cenozóicos. A Figura $26 \mathrm{~B}$ mostra um padrão enriquecido em $\mathrm{Al}_{2} \mathrm{O}_{3}$ para os lherzolitos, teores intermediários para os harzburgitos e baixos para flogopita dunito e xenólito polimítico. Os dados do clinopiroxênio do lherzolito projetam-se no campo dos peridotitos não cratônicos, e o clinopiroxênio dos harzburgitos projeta-se principalmente no campo dos peridotitos cratônicos. 
Tabela 7- Análises químicas de clinopiroxênio de xenólitos da intrusão Indaiá 1, obtidas por meio da microssonda eletrônica.

\begin{tabular}{|c|c|c|c|c|c|c|c|c|c|c|c|c|c|c|}
\hline & \multirow{2}{*}{$\begin{array}{c}\text { Harzburgito } \\
\qquad 1 / 1\end{array}$} & \multicolumn{6}{|c|}{ Flogopita dunito } & \multicolumn{7}{|c|}{ Harzburgito com textura granoblástica } \\
\hline 2 & & $2 / 1$ & $2 / 2$ & $2 / 3$ & $2 / 4$ & $2 / 5$ & $2 / 6$ & $3 / 1$ & $3 / 2$ & $3 / 3$ & $3 / 4$ & $3 / 5$ & $3 / 6$ & $3 / 7$ \\
\hline $\mathrm{SiO}_{2}^{2}$ & 53,24 & 54,94 & 54,88 & 55,63 & 54,91 & 55,53 & 54,79 & 52,75 & 53,69 & 53,29 & 53,62 & 54,03 & 54,03 & 53,12 \\
\hline $\mathrm{TiO}^{2}$ & 1,46 & 0,33 & 0,27 & 0,19 & 0,30 & 0,17 & 0,51 & 0,07 & 0,06 & 0,03 & 0,10 & 0,00 & 0,00 & 0,04 \\
\hline $\mathrm{Al} \mathrm{O}$ & 0,30 & 0,36 & 0,42 & 0,41 & 0,67 & 0,40 & 0,22 & 2,10 & 1,86 & 1,96 & 2,22 & 2,06 & 2,13 & 2,13 \\
\hline $\mathrm{FeO}$ & 5,18 & 3,11 & 3,03 & 2,81 & 3,16 & 2,95 & 2,69 & 1,70 & 1,54 & 1,55 & 1,79 & 1,38 & 1,59 & 1,73 \\
\hline $\mathrm{MnO}$ & 0,13 & 0,07 & 0,11 & 0,13 & 0,15 & 0,09 & 0,04 & 0,05 & 0,05 & 0,04 & 0,11 & 0,07 & 0,02 & 0,07 \\
\hline $\mathrm{MgO}$ & 18,01 & 17,45 & 17,56 & 17,81 & 17,75 & 17,74 & 17,62 & 17,76 & 18,16 & 17,45 & 18,37 & 17,63 & 17,57 & 17,62 \\
\hline $\mathrm{CaO}$ & 20,57 & 21,51 & 21,16 & 21,67 & 21,58 & 21,32 & 23,96 & 22,14 & 21,73 & 23,05 & 22,18 & 23,31 & 23,34 & 22,42 \\
\hline $\mathrm{Na} 2 \mathrm{O}$ & 0,80 & 1,07 & 1,03 & 0,98 & 1,01 & 1,10 & 0,58 & 0,76 & 0,76 & 0,90 & 0,82 & 0,70 & 0,75 & 0,73 \\
\hline $\mathrm{K}^{2} 2 \mathrm{O}^{3}$ & 0,00 & 0,01 & 0,00 & 0,02 & 0,03 & 0,02 & 0,22 & 0,00 & 0,00 & 0,01 & 0,00 & 0,00 & 0,01 & 0,00 \\
\hline $\mathrm{CrO}$ & 0,10 & 1,80 & 1,34 & 1,51 & 1,42 & 1,77 & 0,11 & 1,01 & 0,86 & 0,87 & 1,09 & 0,91 & 0,96 & 1,04 \\
\hline Total & 99,80 & 100,65 & 99,80 & 101,16 & 100,96 & 101,08 & 100,74 & 98,35 & 98,71 & 99,14 & 100,30 & 100,10 & 100,40 & 98,90 \\
\hline \multicolumn{15}{|c|}{ Número de cátions com base em 6 átomos de oxigênio } \\
\hline $\mathrm{TSi}$ & 1,942 & 1,983 & 1,994 & 1,994 & 1,972 & 1,992 & 1,972 & 1,932 & 1,957 & 1,936 & 1,924 & 1,947 & 1,942 & 1,937 \\
\hline TAl & 0,013 & 0,015 & 0,006 & 0,006 & 0,028 & 0,008 & 0,009 & 0,068 & 0,043 & 0,064 & 0,076 & 0,053 & 0,058 & 0,063 \\
\hline TFe3 & 0,045 & 0,002 & 0,000 & 0,000 & 0,000 & 0,000 & 0,019 & 0,000 & 0,000 & 0,000 & 0,000 & 0,000 & 0,000 & 0,000 \\
\hline M1Al & 0,000 & 0,000 & 0,012 & 0,011 & 0,000 & 0,009 & 0,000 & 0,023 & 0,036 & 0,020 & 0,017 & 0,034 & 0,032 & 0,029 \\
\hline M1Ti & 0,040 & 0,009 & 0,007 & 0,005 & 0,008 & 0,005 & 0,014 & 0,002 & 0,002 & 0,001 & 0,003 & 0,000 & 0,000 & 0,001 \\
\hline M1Fe3 & 0,031 & 0,023 & 0,014 & 0,011 & 0,043 & 0,017 & 0,048 & 0,000 & 0,032 & 0,000 & 0,000 & 0,041 & 0,000 & 0,000 \\
\hline $\mathrm{M} 1 \mathrm{Fe} 2$ & 0,000 & 0,000 & 0,000 & 0,000 & 0,000 & 0,000 & 0,000 & 0,000 & 0,000 & 0,009 & 0,000 & 0,000 & 0,000 & 0,000 \\
\hline $\mathrm{M} 1 \mathrm{Cr}$ & 0,003 & 0,051 & 0,038 & 0,043 & 0,040 & 0,050 & 0,003 & 0,029 & 0,025 & 0,025 & 0,031 & 0,026 & 0,027 & 0,030 \\
\hline M1Mg & 0,926 & 0,916 & 0,929 & 0,930 & 0,908 & 0,919 & 0,935 & 0,946 & 0,905 & 0,945 & 0,949 & 0,898 & 0,941 & 0,940 \\
\hline $\mathrm{M} 1 \mathrm{Ni}$ & 0,000 & 0,000 & 0,000 & 0,000 & 0,000 & 0,000 & 0,000 & 0,000 & 0,000 & 0,000 & 0,000 & 0,000 & 0,000 & 0,000 \\
\hline M2Mg & 0,054 & 0,022 & 0,022 & 0,021 & 0,042 & 0,029 & 0,010 & 0,024 & 0,082 & 0,000 & 0,033 & 0,049 & 0,000 & 0,017 \\
\hline M2Fe2 & 0,082 & 0,069 & 0,078 & 0,073 & 0,052 & 0,071 & 0,014 & 0,052 & 0,015 & 0,038 & 0,054 & 0,000 & 0,048 & 0,053 \\
\hline M2Mn & 0,004 & 0,002 & 0,003 & 0,004 & 0,005 & 0,003 & 0,001 & 0,002 & 0,002 & 0,001 & 0,003 & 0,002 & 0,001 & 0,002 \\
\hline $\mathrm{M} 2 \mathrm{Ca}$ & 0,804 & 0,832 & 0,824 & 0,832 & 0,830 & 0,819 & 0,924 & 0,869 & 0,848 & 0,897 & 0,853 & 0,900 & 0,899 & 0,876 \\
\hline M2Na & 0,057 & 0,075 & 0,073 & 0,068 & 0,070 & 0,077 & 0,040 & 0,054 & 0,054 & 0,063 & 0,057 & 0,049 & 0,052 & 0,052 \\
\hline M2K & 0,000 & 0,000 & 0,000 & 0,001 & 0,001 & 0,001 & 0,010 & 0,000 & 0,000 & 0,000 & 0,000 & 0,000 & 0,000 & 0,000 \\
\hline Sum_cat & 4,000 & 4,000 & 4,000 & 3,999 & 3,999 & 3,999 & 3,990 & 4,000 & 4,000 & 4,000 & 4,000 & 4,000 & 4,000 & 4,000 \\
\hline $\mathrm{Ca}$ & 43,014 & 45,172 & 44,372 & 44,713 & 45,205 & 44,487 & 49,025 & 45,917 & 45,834 & 47,456 & 45,059 & 48,660 & 47,590 & 46,378 \\
\hline $\mathrm{Mg}$ & 52,401 & 50,989 & 51,235 & 51,131 & 51,734 & 51,505 & 50,163 & 51,249 & 53,296 & 49,988 & 51,926 & 51,208 & 49,847 & 50,714 \\
\hline Fe2_Mn & 4,585 & 3,839 & 4,392 & 4,156 & 3,061 & 4,007 & 0,812 & 2,834 & 0,870 & 2,556 & 3,015 & 0,132 & 2,563 & 2,908 \\
\hline JD1 & 0,000 & 0,000 & 0,604 & 0,580 & 0,003 & 0,454 & 0,000 & 1,166 & 1,913 & 1,014 & 0,893 & 1,814 & 1,636 & 1,474 \\
\hline $\mathrm{AE} 1$ & 2,945 & 3,935 & 3,165 & 3,003 & 3,763 & 3,586 & 2,615 & 1,610 & 0,909 & 2,256 & 2,039 & 0,765 & 1,081 & 1,189 \\
\hline CFTS1 & 0,000 & 0,000 & 0,000 & 0,000 & 0,623 & 0,000 & 0,028 & 0,000 & 2,092 & 0,000 & 0,000 & 2,778 & 0,323 & 0,356 \\
\hline CTTS1 & 0,671 & 0,468 & 0,330 & 0,266 & 0,426 & 0,239 & 0,482 & 0,099 & 0,086 & 0,042 & 0,139 & 0,000 & 0,000 & 0,057 \\
\hline CATS1 & 0,000 & 0,000 & 0,000 & 0,000 & 0,000 & 0,000 & 0,000 & 0,000 & 0,000 & 0,000 & 0,000 & 0,000 & 0,000 & 0,000 \\
\hline WO1 & 41,167 & 42,977 & 42,448 & 42,936 & 42,562 & 42,514 & 47,263 & 44,580 & 42,399 & 45,892 & 43,677 & 44,682 & 45,989 & 44,782 \\
\hline EN1 & 50,968 & 49,039 & 49,395 & 49,404 & 49,910 & 49,498 & 48,883 & 49,868 & 51,835 & 48,385 & 50,493 & 49,945 & 48,508 & 49,420 \\
\hline FS1 & 4,250 & 3,580 & 4,059 & 3,811 & 2,713 & 3,708 & 0,729 & 2,678 & 0,765 & 2,411 & 2,760 & 0,016 & 2,463 & 2,722 \\
\hline Q & 1,865 & 1,839 & 1,853 & 1,857 & 1,832 & 1,839 & 1,883 & 1,891 & 1,850 & 1,889 & 1,889 & 1,847 & 1,888 & 1,887 \\
\hline $\mathrm{J}$ & 0,113 & 0,150 & 0,145 & 0,136 & 0,141 & 0,153 & 0,081 & 0,108 & 0,107 & 0,127 & 0,114 & 0,098 & 0,105 & 0,103 \\
\hline WO & 41,326 & 44,559 & 44,042 & 44,454 & 44,165 & 44,070 & 47,345 & 45,917 & 45,046 & 47,456 & 45,059 & 47,598 & 47,590 & 46,378 \\
\hline EN & 50,344 & 50,297 & 50,854 & 50,835 & 50,544 & 51,023 & 48,444 & 51,249 & 52,380 & 49,988 & 51,926 & 50,090 & 49,847 & 50,714 \\
\hline FS & 8,330 & 5,143 & 5,104 & 4,710 & 5,291 & 4,907 & 4,211 & 2,834 & 2,574 & 2,556 & 3,015 & 2,313 & 2,563 & 2,908 \\
\hline WEF & 94,291 & 92,478 & 92,749 & 93,180 & 92,887 & 92,329 & 95,881 & 94,603 & 94,516 & 93,715 & 94,313 & 94,977 & 94,755 & 94,818 \\
\hline JD & 0,000 & 0,000 & 3,300 & 3,463 & 0,009 & 2,553 & 0,000 & 5,397 & 2,903 & 6,285 & 5,687 & 2,283 & 5,245 & 5,182 \\
\hline $\mathrm{AE}$ & 5,709 & 7,522 & 3,951 & 3,357 & 7,104 & 5,118 & 4,119 & 0,000 & 2,581 & 0,000 & 0,000 & 2,740 & 0,000 & 0,000 \\
\hline
\end{tabular}


Tabela 7- Continuação.

\begin{tabular}{|c|c|c|c|c|c|c|c|c|c|c|}
\hline & \multicolumn{6}{|c|}{ Lherzolito com textura porfiroclástica } & \multicolumn{4}{|c|}{ Xenólito polimítico } \\
\hline 2 & $4 / 1$ & $4 / 2$ & $4 / 3$ & $4 / 4$ & $4 / 5$ & $4 / 6$ & $6 / 1$ & $6 / 2$ & $6 / 3$ & $6 / 4$ \\
\hline $\mathrm{SiO}_{3}^{2}$ & 53,47 & 52,56 & 52,61 & 52,47 & 52,78 & 53,37 & 54,21 & 54,44 & 54,34 & 54,20 \\
\hline $\mathrm{TiO}^{2}$ & 0,32 & 0,20 & 0,40 & 0,31 & 0,35 & 0,26 & 0,12 & 0,26 & 0,16 & 0,05 \\
\hline $\mathrm{Al} \mathrm{O}$ & 6,11 & 7,10 & 6,46 & 6,73 & 5,97 & 6,49 & 0,29 & 0,22 & 0,29 & 0,28 \\
\hline $\mathrm{FeO}$ & 1,76 & 2,03 & 0,02 & 2,07 & 1,77 & 1,87 & 4,40 & 4,35 & 4,28 & 4,18 \\
\hline $\mathrm{MnO}$ & 0,09 & 0,08 & 0,11 & 0,05 & 0,06 & 0,09 & 0,10 & 0,18 & 0,11 & 0,14 \\
\hline $\mathrm{MgO}$ & 14,65 & 15,08 & 14,86 & 14,64 & 14,50 & 14,37 & 17,16 & 17,13 & 17,31 & 17,29 \\
\hline $\mathrm{CaO}$ & 21,99 & 21,32 & 21,94 & 21,86 & 22,61 & 22,33 & 22,06 & 21,58 & 22,39 & 22,14 \\
\hline $\mathrm{Na}_{2} 2 \mathrm{O}_{3}$ & 1,77 & 1,67 & 1,69 & 1,67 & 1,65 & 1,68 & 0,75 & 0,75 & 0,76 & 0,74 \\
\hline $\mathrm{K}^{2} 2 \mathrm{O}^{3}$ & 0,00 & 0,00 & 0,00 & 0,02 & 0,01 & 0,00 & 0,04 & 0,04 & 0,01 & 0,01 \\
\hline $\mathrm{CrO}$ & 0,90 & 1,14 & 1,01 & 1,06 & 0,89 & 1,00 & 0,47 & 0,50 & 0,40 & 0,48 \\
\hline Total & 101,06 & 101,16 & 99,09 & 100,86 & 100,58 & 101,46 & 99,60 & 99,45 & 100,05 & 99,50 \\
\hline \multicolumn{11}{|c|}{ Número de cátions com base em 6 átomos de oxigênio } \\
\hline TSi & 1,910 & 1,872 & 1,907 & 1,878 & 1,896 & 1,902 & 1,980 & 1,993 & 1,975 & 1,980 \\
\hline TAl & 0,090 & 0,128 & 0,093 & 0,122 & 0,104 & 0,098 & 0,012 & 0,007 & 0,012 & 0,012 \\
\hline TFe3 & 0,000 & 0,000 & 0,000 & 0,000 & 0,000 & 0,000 & 0,007 & 0,000 & 0,013 & 0,008 \\
\hline M1Al & 0,167 & 0,170 & 0,183 & 0,162 & 0,148 & 0,174 & 0,000 & 0,003 & 0,000 & 0,000 \\
\hline M1Ti & 0,009 & 0,005 & 0,011 & 0,008 & 0,009 & 0,007 & 0,003 & 0,007 & 0,004 & 0,001 \\
\hline M1Fe3 & 0,003 & 0,029 & 0,000 & 0,029 & 0,026 & 0,000 & 0,054 & 0,030 & 0,059 & 0,056 \\
\hline M1Fe2 & 0,017 & 0,000 & 0,000 & 0,000 & 0,014 & 0,027 & 0,000 & 0,010 & 0,000 & 0,000 \\
\hline $\mathrm{M} 1 \mathrm{Cr}$ & 0,025 & 0,032 & 0,029 & 0,030 & 0,025 & 0,028 & 0,014 & 0,014 & 0,011 & 0,014 \\
\hline $\mathrm{M} 1 \mathrm{Mg}$ & 0,780 & 0,763 & 0,778 & 0,771 & 0,776 & 0,763 & 0,929 & 0,935 & 0,925 & 0,928 \\
\hline $\mathrm{M} 1 \mathrm{Ni}$ & 0,000 & 0,000 & 0,000 & 0,000 & 0,000 & 0,000 & 0,000 & 0,000 & 0,000 & 0,000 \\
\hline $\mathrm{M} 2 \mathrm{Mg}$ & 0,000 & 0,038 & 0,025 & 0,011 & 0,000 & 0,000 & 0,006 & 0,000 & 0,013 & 0,013 \\
\hline $\mathrm{M} 2 \mathrm{Fe} 2$ & 0,033 & 0,031 & 0,001 & 0,033 & 0,013 & 0,029 & 0,073 & 0,093 & 0,058 & 0,063 \\
\hline M2Mn & 0,003 & 0,002 & 0,003 & 0,002 & 0,002 & 0,003 & 0,003 & 0,006 & 0,003 & 0,004 \\
\hline $\mathrm{M} 2 \mathrm{Ca}$ & 0,841 & 0,814 & 0,852 & 0,838 & 0,870 & 0,853 & 0,863 & 0,847 & 0,872 & 0,866 \\
\hline $\mathrm{M} 2 \mathrm{Na}$ & 0,123 & 0,115 & 0,119 & 0,116 & 0,115 & 0,116 & 0,053 & 0,053 & 0,054 & 0,052 \\
\hline M2K & 0,000 & 0,000 & 0,000 & 0,001 & 0,000 & 0,000 & 0,002 & 0,002 & 0,000 & 0,000 \\
\hline Sum_cat & 4,000 & 4,000 & 4,000 & 3,999 & 4,000 & 4,000 & 3,998 & 3,998 & 4,000 & 4,000 \\
\hline $\mathrm{Ca}$ & 50,268 & 49,377 & 51,359 & 50,697 & 51,938 & 50,918 & 46,081 & 44,785 & 46,590 & 46,200 \\
\hline $\mathrm{Mg}$ & 46,596 & 48,595 & 48,401 & 47,242 & 46,345 & 45,592 & 49,875 & 49,464 & 50,117 & 50,201 \\
\hline $\mathrm{Fe} 2 \_\mathrm{Mn}$ & 3,136 & 2,028 & 0,240 & 2,061 & 1,718 & 3,491 & 4,045 & 5,750 & 3,292 & 3,599 \\
\hline JD1 & 6,833 & 6,551 & 6,694 & 6,604 & 6,450 & 6,493 & 0,000 & 0,146 & 0,000 & 0,000 \\
\hline AE1 & 0,000 & 0,000 & 0,000 & 0,000 & 0,000 & 0,000 & 2,856 & 2,695 & 2,811 & 2,748 \\
\hline CFTS1 & 1,571 & 3,494 & 1,629 & 3,356 & 2,877 & 1,574 & 0,678 & 0,000 & 0,856 & 0,902 \\
\hline CTTS1 & 0,479 & 0,304 & 0,615 & 0,464 & 0,529 & 0,390 & 0,171 & 0,343 & 0,228 & 0,071 \\
\hline CATS1 & 2,458 & 3,102 & 3,594 & 2,548 & 1,843 & 3,257 & 0,000 & 0,000 & 0,000 & 0,000 \\
\hline WO1 & 42,401 & 39,309 & 42,181 & 41,025 & 43,392 & 42,468 & 43,990 & 43,299 & 44,279 & 44,061 \\
\hline EN1 & 43,483 & 45,478 & 45,253 & 44,162 & 43,403 & 42,701 & 48,531 & 48,201 & 48,797 & 48,934 \\
\hline FS1 & 2,775 & 1,761 & 0,034 & 1,841 & 1,507 & 3,117 & 3,775 & 5,316 & 3,029 & 3,283 \\
\hline $\mathrm{Q}$ & 1,671 & 1,645 & 1,656 & 1,652 & 1,674 & 1,672 & 1,871 & 1,885 & 1,868 & 1,871 \\
\hline $\mathrm{J}$ & 0,245 & 0,231 & 0,238 & 0,232 & 0,230 & 0,232 & 0,106 & 0,106 & 0,107 & 0,105 \\
\hline WO & 50,184 & 48,510 & 51,359 & 49,812 & 51,137 & 50,918 & 44,611 & 44,084 & 44,867 & 44,664 \\
\hline $\mathrm{EN}$ & 46,519 & 47,741 & 48,401 & 46,416 & 45,631 & 45,592 & 48,284 & 48,689 & 48,264 & 48,531 \\
\hline FS & 3,297 & 3,749 & 0,240 & 3,772 & 3,232 & 3,491 & 7,105 & 7,227 & 6,869 & 6,805 \\
\hline WEF & 87,226 & 87,720 & 87,474 & 87,705 & 87,936 & 87,823 & 94,634 & 94,667 & 94,586 & 94,707 \\
\hline $\mathrm{JD}$ & 12,564 & 10,466 & 12,526 & 10,405 & 10,252 & 12,177 & 0,000 & 0,459 & 0,000 & 0,000 \\
\hline $\mathrm{AE}$ & 0,210 & 1,814 & 0,000 & 1,889 & 1,812 & 0,000 & 5,366 & 4,874 & 5,414 & 5,293 \\
\hline
\end{tabular}


Tabela 7- Continuação.

\begin{tabular}{|c|c|c|c|c|c|c|c|c|c|c|c|c|c|c|}
\hline \multicolumn{10}{|c|}{ Harzburgito com espinélio e textura grossa } & \multicolumn{5}{|c|}{ Harzburgito com bolsões de clinopiroxênio } \\
\hline 2 & $9 / 1$ & $9 / 2$ & $9 / 3$ & $9 / 4$ & $9 / 5$ & $9 / 6$ & $9 / 7$ & $9 / 8$ & $9 / 9$ & $12 / 1$ & $12 / 2$ & $12 / 3$ & $12 / 4$ & $12 / 5$ \\
\hline $\mathrm{SiO}_{3}^{2}$ & 53,68 & 53,40 & 53,46 & 53,13 & 53,65 & 53,51 & 53,42 & 52,72 & 53,75 & 54,44 & 54,27 & 54,41 & 54,54 & 54,11 \\
\hline $\mathrm{TiO}^{2}$ & 0,34 & 0,23 & 0,24 & 0,17 & 0,19 & 0,35 & 0,29 & 0,32 & 0,27 & 0,04 & 0,10 & 0,00 & 0,04 & 0,06 \\
\hline $\mathrm{Al} \mathrm{O}$ & 4,46 & 4,29 & 4,09 & 3,79 & 3,96 & 3,71 & 3,69 & 4,24 & 4,24 & 1,08 & 0,94 & 0,68 & 0,58 & 0,27 \\
\hline $\mathrm{FeO}$ & 1,43 & 1,53 & 1,42 & 1,36 & 1,48 & 1,34 & 1,41 & 1,42 & 1,47 & 2,64 & 2,36 & 2,24 & 2,27 & 1,94 \\
\hline $\mathrm{MnO}$ & 0,04 & 0,05 & 0,04 & 0,07 & 0,08 & 0,05 & 0,05 & 0,07 & 0,08 & 0,12 & 0,11 & 0,04 & 0,07 & 0,07 \\
\hline $\mathrm{MgO}$ & 14,78 & 14,62 & 14,80 & 15,11 & 14,92 & 16,53 & 16,23 & 15,86 & 15,61 & 16,44 & 15,85 & 16,00 & 16,62 & 16,67 \\
\hline $\mathrm{CaO}$ & 22,62 & 22,35 & 22,24 & 22,69 & 22,59 & 23,05 & 22,55 & 22,84 & 22,47 & 19,28 & 20,48 & 20,19 & 21,79 & 21,90 \\
\hline $\mathrm{Na} 2 \mathrm{O}_{2}$ & 1,36 & 1,66 & 1,51 & 1,35 & 1,42 & 1,40 & 1,47 & 1,47 & 1,64 & 2,32 & 2,55 & 2,33 & 1,83 & 1,66 \\
\hline $\mathrm{K}^{2} 2 \mathrm{O}^{3}$ & 0,00 & 0,00 & 0,01 & 0,00 & 0,00 & 0,00 & 0,00 & 0,00 & 0,02 & 0,00 & 0,00 & 0,02 & 0,08 & 0,01 \\
\hline $\mathrm{CrO}$ & 0,77 & 0,99 & 0,85 & 0,61 & 0,92 & 0,65 & 0,73 & 0,83 & 0,86 & 2,88 & 3,53 & 3,91 & 2,66 & 2,85 \\
\hline Total & 99,46 & 99,11 & 98,65 & 98,26 & 99,21 & 100,60 & 99,82 & 99,78 & 100,41 & 99,24 & 100,18 & 99,82 & 100,47 & 99,52 \\
\hline \multicolumn{15}{|c|}{ Número de cátions com base em 6 átomos de oxigênio } \\
\hline TSi & 1,953 & 1,947 & 1,959 & 1,952 & 1,956 & 1,913 & 1,925 & 1,903 & 1,929 & 1,980 & 1,959 & 1,974 & 1,964 & 1,968 \\
\hline TAl & 0,047 & 0,053 & 0,041 & 0,048 & 0,044 & 0,087 & 0,075 & 0,097 & 0,071 & 0,020 & 0,040 & 0,026 & 0,025 & 0,012 \\
\hline TFe3 & 0,000 & 0,000 & 0,000 & 0,000 & 0,000 & 0,000 & 0,000 & 0,000 & 0,000 & 0,000 & 0,000 & 0,000 & 0,000 & 0,000 \\
\hline M1Al & 0,144 & 0,132 & 0,135 & 0,116 & 0,127 & 0,069 & 0,082 & 0,083 & 0,108 & 0,026 & 0,000 & 0,003 & 0,000 & 0,000 \\
\hline M1Ti & 0,009 & 0,006 & 0,007 & 0,005 & 0,005 & 0,009 & 0,008 & 0,009 & 0,007 & 0,001 & 0,003 & 0,000 & 0,001 & 0,002 \\
\hline M1Fe3 & 0,000 & 0,000 & 0,000 & 0,000 & 0,000 & 0,000 & 0,000 & 0,000 & 0,039 & 0,072 & 0,000 & 0,000 & 0,000 & 0,000 \\
\hline $\mathrm{M} 1 \mathrm{Fe} 2$ & 0,023 & 0,039 & 0,025 & 0,033 & 0,031 & 0,022 & 0,017 & 0,031 & 0,000 & 0,000 & 0,044 & 0,019 & 0,031 & 0,012 \\
\hline $\mathrm{M} 1 \mathrm{Cr}$ & 0,022 & 0,029 & 0,025 & 0,018 & 0,026 & 0,018 & 0,021 & 0,024 & 0,024 & 0,083 & 0,101 & 0,112 & 0,076 & 0,082 \\
\hline M1Mg & 0,802 & 0,795 & 0,808 & 0,828 & 0,811 & 0,881 & 0,872 & 0,853 & 0,822 & 0,818 & 0,853 & 0,866 & 0,892 & 0,904 \\
\hline $\mathrm{M} 1 \mathrm{Ni}$ & 0,000 & 0,000 & 0,000 & 0,000 & 0,000 & 0,000 & 0,000 & 0,000 & 0,000 & 0,000 & 0,000 & 0,000 & 0,000 & 0,000 \\
\hline $\mathrm{M} 2 \mathrm{Mg}$ & 0,000 & 0,000 & 0,000 & 0,000 & 0,000 & 0,000 & 0,000 & 0,000 & 0,013 & 0,074 & 0,000 & 0,000 & 0,000 & 0,000 \\
\hline $\mathrm{M} 2 \mathrm{Fe} 2$ & 0,021 & 0,008 & 0,018 & 0,008 & 0,014 & 0,018 & 0,025 & 0,012 & 0,005 & 0,008 & 0,027 & 0,049 & 0,037 & 0,047 \\
\hline $\mathrm{M} 2 \mathrm{Mn}$ & 0,001 & 0,002 & 0,001 & 0,002 & 0,002 & 0,002 & 0,002 & 0,002 & 0,002 & 0,004 & 0,003 & 0,001 & 0,002 & 0,002 \\
\hline $\mathrm{M} 2 \mathrm{Ca}$ & 0,882 & 0,873 & 0,873 & 0,893 & 0,883 & 0,883 & 0,871 & 0,883 & 0,864 & 0,751 & 0,792 & 0,785 & 0,841 & 0,854 \\
\hline $\mathrm{M} 2 \mathrm{Na}$ & 0,096 & 0,117 & 0,107 & 0,096 & 0,100 & 0,097 & 0,103 & 0,103 & 0,114 & 0,164 & 0,178 & 0,164 & 0,128 & 0,117 \\
\hline M2K & 0,000 & 0,000 & 0,000 & 0,000 & 0,000 & 0,000 & 0,000 & 0,000 & 0,001 & 0,000 & 0,000 & 0,001 & 0,004 & 0,000 \\
\hline Sum_cat & 4,000 & 4,000 & 4,000 & 4,000 & 4,000 & 4,000 & 4,000 & 4,000 & 3,999 & 4,000 & 4,000 & 3,999 & 3,996 & 4,000 \\
\hline $\mathrm{Ca}$ & 51,023 & 50,881 & 50,577 & 50,613 & 50,687 & 48,902 & 48,733 & 49,575 & 50,621 & 45,416 & 46,061 & 45,645 & 46,618 & 46,931 \\
\hline $\mathrm{Mg}$ & 46,387 & 46,310 & 46,831 & 46,896 & 46,579 & 48,795 & 48,803 & 47,899 & 48,931 & 53,884 & 49,600 & 50,330 & 49,473 & 49,705 \\
\hline Fe2_Mn & 2,589 & 2,809 & 2,593 & 2,491 & 2,734 & 2,303 & 2,464 & 2,526 & 0,448 & 0,700 & 4,339 & 4,024 & 3,909 & 3,364 \\
\hline JD1 & 5,263 & 6,407 & 5,879 & 5,174 & 5,459 & 3,654 & 4,336 & 4,415 & 5,930 & 1,438 & 0,000 & 0,181 & 0,000 & 0,000 \\
\hline AE1 & 0,000 & 0,000 & 0,000 & 0,000 & 0,000 & 1,451 & 1,105 & 1,050 & 0,393 & 7,581 & 9,420 & 8,573 & 6,801 & 6,078 \\
\hline CFTS1 & 1,214 & 1,556 & 1,342 & 0,952 & 1,440 & 0,000 & 0,000 & 0,206 & 3,085 & 0,970 & 0,000 & 0,000 & 0,000 & 0,000 \\
\hline CTTS1 & 0,510 & 0,344 & 0,361 & 0,253 & 0,283 & 0,495 & 0,416 & 0,462 & 0,401 & 0,060 & 0,143 & 0,000 & 0,056 & 0,085 \\
\hline CATS1 & 2,057 & 0,774 & 1,489 & 1,085 & 1,420 & 0,000 & 0,000 & 0,000 & 0,000 & 0,000 & 0,000 & 0,000 & 0,000 & 0,000 \\
\hline WO1 & 44,592 & 44,990 & 44,446 & 45,763 & 44,844 & 45,949 & 45,705 & 46,254 & 44,003 & 40,382 & 41,661 & 41,679 & 43,442 & 44,046 \\
\hline EN1 & 43,977 & 43,382 & 44,109 & 44,525 & 44,099 & 46,343 & 46,187 & 45,335 & 45,902 & 49,134 & 45,016 & 45,957 & 46,163 & 46,740 \\
\hline FS1 & 2,387 & 2,547 & 2,374 & 2,248 & 2,454 & 2,107 & 2,251 & 2,277 & 0,287 & 0,435 & 3,760 & 3,609 & 3,537 & 3,051 \\
\hline Q & 1,727 & 1,715 & 1,725 & 1,763 & 1,739 & 1,804 & 1,785 & 1,780 & 1,704 & 1,650 & 1,716 & 1,718 & 1,801 & 1,817 \\
\hline $\mathrm{J}$ & 0,192 & 0,235 & 0,215 & 0,192 & 0,201 & 0,194 & 0,205 & 0,206 & 0,228 & 0,327 & 0,357 & 0,328 & 0,256 & 0,234 \\
\hline WO & 51,023 & 50,881 & 50,577 & 50,613 & 50,687 & 48,902 & 48,733 & 49,575 & 49,493 & 43,512 & 46,061 & 45,645 & 46,618 & 46,931 \\
\hline EN & 46,387 & 46,310 & 46,831 & 46,896 & 46,579 & 48,795 & 48,803 & 47,899 & 47,840 & 51,624 & 49,600 & 50,330 & 49,473 & 49,705 \\
\hline FS & 2,589 & 2,809 & 2,593 & 2,491 & 2,734 & 2,303 & 2,464 & 2,526 & 2,667 & 4,865 & 4,339 & 4,024 & 3,909 & 3,364 \\
\hline WEF & 90,006 & 87,967 & 88,945 & 90,172 & 89,660 & 90,293 & 89,687 & 89,647 & 88,205 & 83,486 & 82,810 & 83,987 & 87,588 & 88,593 \\
\hline $\mathrm{JD}$ & 9,994 & 12,033 & 11,055 & 9,828 & 10,340 & 9,707 & 10,313 & 10,353 & 8,670 & 4,373 & 0,000 & 16,013 & 0,000 & 0,000 \\
\hline $\mathrm{AE}$ & 0,000 & 0,000 & 0,000 & 0,000 & 0,000 & 0,000 & 0,000 & 0,000 & 3,126 & 12,141 & 0,178 & 0,000 & 0,131 & 0,118 \\
\hline
\end{tabular}


Tabela 7- Continuação.

\begin{tabular}{|c|c|c|c|c|c|c|c|c|c|c|c|}
\hline 2 & \multicolumn{4}{|c|}{ Lherzolito com espinélio } & Harzburgito & \multicolumn{6}{|c|}{ Lherzolito com espinélio e textura grossa } \\
\hline $\mathrm{SiO}^{2}$ & $13 \mathrm{a} / 1$ & $13 \mathrm{a} / 2$ & $13 \mathrm{a} / 3$ & $13 \mathrm{a} / 4$ & $13 \mathrm{~b} / 1$ & $14 \mathrm{a} / 1$ & $14 \mathrm{a} / 2$ & $14 \mathrm{a} / 3$ & $14 \mathrm{a} / 4$ & $14 \mathrm{a} / 5$ & $14 \mathrm{a} / 6$ \\
\hline $\mathrm{TiO}^{2}$ & 52,85 & 52,91 & 52,94 & 52,66 & 53,12 & 53,71 & 53,81 & 52,85 & 54,25 & 51,32 & 54,26 \\
\hline $\mathrm{Al} \mathrm{O}$ & 0,40 & 0,46 & 0,36 & 0,30 & 0,03 & 0,21 & 0,27 & 0,15 & 0,25 & 0,27 & 0,30 \\
\hline $\mathrm{FeO}$ & 3,78 & 3,87 & 3,95 & 3,68 & 3,39 & 3,80 & 3,61 & 4,46 & 4,03 & 6,50 & 3,79 \\
\hline $\mathrm{MnO}$ & 1,39 & 1,61 & 1,45 & 1,32 & 1,47 & 1,61 & 1,45 & 1,61 & 1,48 & 1,75 & 1,32 \\
\hline $\mathrm{MgO}$ & 0,04 & 0,05 & 0,05 & 0,06 & 0,05 & 0,06 & 0,05 & 0,05 & 0,06 & 0,07 & 0,07 \\
\hline $\mathrm{CaO}$ & 16,03 & 15,90 & 15,76 & 15,84 & 16,50 & 14,89 & 14,85 & 15,31 & 14,83 & 15,19 & 14,74 \\
\hline $\mathrm{Na}_{2} \mathrm{O}$ & 22,74 & 22,27 & 21,82 & 22,59 & 23,11 & 22,69 & 23,03 & 22,63 & 22,80 & 21,76 & 22,54 \\
\hline $\mathrm{K} 2 \mathrm{O}^{3}$ & 1,53 & 1,56 & 1,48 & 1,60 & 1,27 & 1,34 & 1,45 & 1,26 & 1,48 & 1,37 & 1,52 \\
\hline $\mathrm{CrO}$ & 0,00 & 0,00 & 0,02 & 0,00 & 0,00 & 0,00 & 0,00 & 0,00 & 0,00 & 0,00 & 0,00 \\
\hline \multirow[t]{2}{*}{ Total } & 1,36 & 1,39 & 1,36 & 1,40 & 1,20 & 0,75 & 0,87 & 0,92 & 0,84 & 1,30 & 0,87 \\
\hline & 100,12 & 100,03 & 99,19 & 99,43 & 100,13 & 99,04 & 99,39 & 99,24 & 100,02 & 99,54 & 99,41 \\
\hline \multicolumn{12}{|c|}{ Número de cátions com base em 6 átomos de oxigênio } \\
\hline $\mathrm{TSi}$ & 1,903 & 1,909 & 1,926 & 1,908 & 1,911 & 1,963 & 1,960 & 1,925 & 1,963 & 1,860 & 1,975 \\
\hline $\mathrm{TAl}$ & 0,097 & 0,091 & 0,074 & 0,092 & 0,089 & 0,037 & 0,040 & 0,075 & 0,037 & 0,140 & 0,025 \\
\hline $\mathrm{TFe} 3$ & 0,000 & 0,000 & 0,000 & 0,000 & 0,000 & 0,000 & 0,000 & 0,000 & 0,000 & 0,000 & 0,000 \\
\hline M1Al & 0,063 & 0,073 & 0,095 & 0,065 & 0,055 & 0,127 & 0,115 & 0,116 & 0,135 & 0,138 & 0,138 \\
\hline M1Ti & 0,011 & 0,012 & 0,010 & 0,008 & 0,001 & 0,006 & 0,007 & 0,004 & 0,007 & 0,007 & 0,008 \\
\hline M1Fe3 & 0,000 & 0,000 & 0,025 & 0,000 & 0,000 & 0,000 & 0,000 & 0,013 & 0,000 & 0,045 & 0,000 \\
\hline M1Fe2 & 0,027 & 0,020 & 0,000 & 0,031 & 0,025 & 0,035 & 0,044 & 0,009 & 0,034 & 0,000 & 0,029 \\
\hline $\mathrm{M} 1 \mathrm{Cr}$ & 0,039 & 0,040 & 0,039 & 0,040 & 0,034 & 0,022 & 0,025 & 0,026 & 0,024 & 0,037 & 0,025 \\
\hline $\mathrm{M} 1 \mathrm{Mg}$ & 0,860 & 0,855 & 0,831 & 0,856 & 0,885 & 0,811 & 0,806 & 0,831 & 0,800 & 0,772 & 0,800 \\
\hline M1Ni & 0,000 & 0,000 & 0,000 & 0,000 & 0,000 & 0,000 & 0,000 & 0,000 & 0,000 & 0,000 & 0,000 \\
\hline $\mathrm{M} 2 \mathrm{Mg}$ & 0,000 & 0,000 & 0,024 & 0,000 & 0,000 & 0,000 & 0,000 & 0,000 & 0,000 & 0,048 & 0,000 \\
\hline $\mathrm{M} 2 \mathrm{Fe} 2$ & 0,015 & 0,029 & 0,019 & 0,009 & 0,019 & 0,015 & 0,000 & 0,027 & 0,010 & 0,008 & 0,011 \\
\hline $\mathrm{M} 2 \mathrm{Mn}$ & 0,001 & 0,002 & 0,002 & 0,002 & 0,002 & 0,002 & 0,002 & 0,002 & 0,002 & 0,002 & 0,002 \\
\hline $\mathrm{M} 2 \mathrm{Ca}$ & 0,877 & 0,861 & 0,850 & 0,877 & 0,891 & 0,889 & 0,899 & 0,883 & 0,884 & 0,845 & 0,879 \\
\hline $\mathrm{M} 2 \mathrm{Na}$ & 0,107 & 0,109 & 0,104 & 0,112 & 0,089 & 0,095 & 0,102 & 0,089 & 0,104 & 0,096 & 0,107 \\
\hline $\mathrm{M} 2 \mathrm{~K}$ & 0,000 & 0,000 & 0,001 & 0,000 & 0,000 & 0,000 & 0,000 & 0,000 & 0,000 & 0,000 & 0,000 \\
\hline Sum_cat & 4,000 & 4,000 & 3,999 & 4,000 & 4,000 & 4,000 & 4,000 & 4,000 & 4,000 & 4,000 & 4,000 \\
\hline $\mathrm{Ca}$ & 49,263 & 48,742 & 49,283 & 49,423 & 48,905 & 50,747 & 51,334 & 50,414 & 51,079 & 50,424 & 51,071 \\
\hline $\mathrm{Mg}$ & 48,318 & 48,421 & 49,527 & 48,219 & 48,583 & 46,336 & 46,056 & 47,456 & 46,227 & 48,976 & 46,469 \\
\hline Fe2_Mn & 2,419 & 2,837 & 1,190 & 2,358 & 2,512 & 2,917 & 2,611 & 2,130 & 2,694 & 0,600 & 2,460 \\
\hline JD1 & 3,343 & 3,896 & 5,194 & 3,449 & 2,874 & 5,150 & 5,531 & 4,838 & 5,666 & 5,440 & 5,874 \\
\hline AE1 & 2,320 & 1,929 & 0,564 & 2,515 & 1,768 & 0,000 & 0,000 & 0,000 & 0,000 & 0,000 & 0,000 \\
\hline CFTS1 & 0,000 & 0,185 & 2,945 & 0,000 & 0,019 & 1,174 & 1,351 & 2,160 & 1,310 & 4,653 & 1,369 \\
\hline CTTS1 & 0,574 & 0,666 & 0,538 & 0,434 & 0,043 & 0,313 & 0,399 & 0,223 & 0,371 & 0,416 & 0,450 \\
\hline CATS 1 & 0,000 & 0,000 & 0,000 & 0,000 & 0,000 & 1,688 & 0,658 & 1,460 & 1,645 & 2,349 & 0,896 \\
\hline WO1 & 45,931 & 45,092 & 43,003 & 46,090 & 46,613 & 45,010 & 46,129 & 44,173 & 44,910 & 40,325 & 45,416 \\
\hline EN1 & 45,613 & 45,640 & 46,718 & 45,391 & 46,367 & 43,997 & 43,547 & 45,200 & 43,654 & 46,372 & 43,795 \\
\hline FS1 & 2,219 & 2,593 & 1,038 & 2,122 & 2,317 & 2,669 & 2,385 & 1,945 & 2,444 & 0,446 & 2,200 \\
\hline $\mathrm{Q}$ & 1,779 & 1,764 & 1,724 & 1,773 & 1,820 & 1,749 & 1,749 & 1,750 & 1,729 & 1,674 & 1,719 \\
\hline $\mathrm{J}$ & 0,214 & 0,218 & 0,209 & 0,225 & 0,177 & 0,190 & 0,205 & 0,178 & 0,208 & 0,193 & 0,215 \\
\hline WO & 49,263 & 48,742 & 48,576 & 49,423 & 48,905 & 50,747 & 51,334 & 50,035 & 51,079 & 49,101 & 51,071 \\
\hline EN & 48,318 & 48,421 & 48,817 & 48,219 & 48,583 & 46,336 & 46,056 & 47,099 & 46,227 & 47,692 & 46,469 \\
\hline FS & 2,419 & 2,837 & 2,608 & 2,358 & 2,512 & 2,917 & 2,611 & 2,866 & 2,694 & 3,207 & 2,460 \\
\hline WEF & 89,288 & 89,001 & 89,207 & 88,755 & 91,135 & 90,214 & 89,527 & 90,777 & 89,285 & 89,694 & 88,916 \\
\hline $\mathrm{JD}$ & 10,712 & 10,999 & 8,536 & 11,245 & 8,865 & 9,786 & 10,473 & 8,275 & 10,715 & 7,764 & 11,084 \\
\hline $\mathrm{AE}$ & 0,000 & 0,000 & 2,257 & 0,000 & 0,000 & 0,000 & 0,000 & 0,948 & 0,000 & 2,543 & 0,000 \\
\hline
\end{tabular}



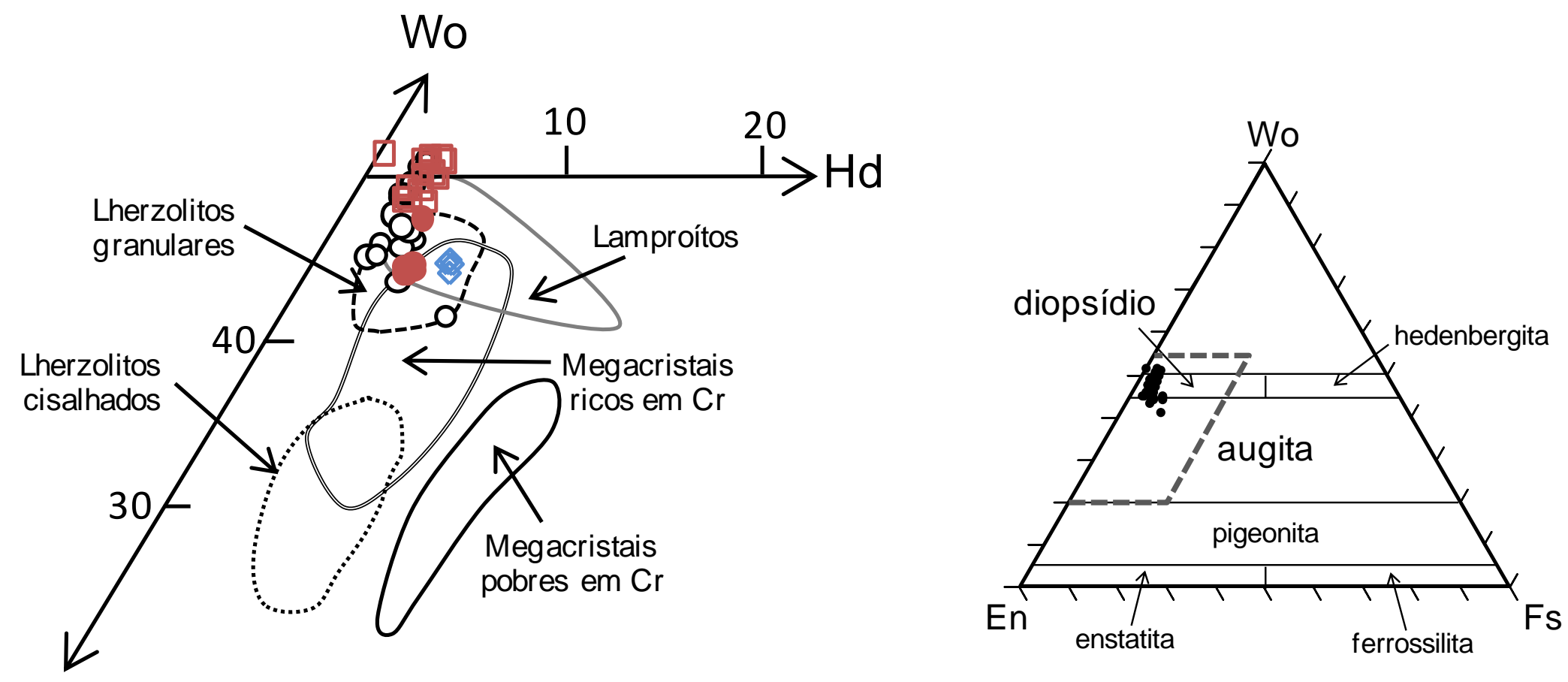

oHarzburgitos $\quad$ Lherzolitos $\quad$ Flogopita dunito $\diamond$ Xenólito polimítico

Figura 25- Composição química de clinopiroxênio de xenólitos do Kimberlito Indaiá. As amostras estudadas correspondem em sua maior parte o diopsídio, e alguns a augita. Projetam-se nos campos de lherzolitos granulares e lamproítos. 

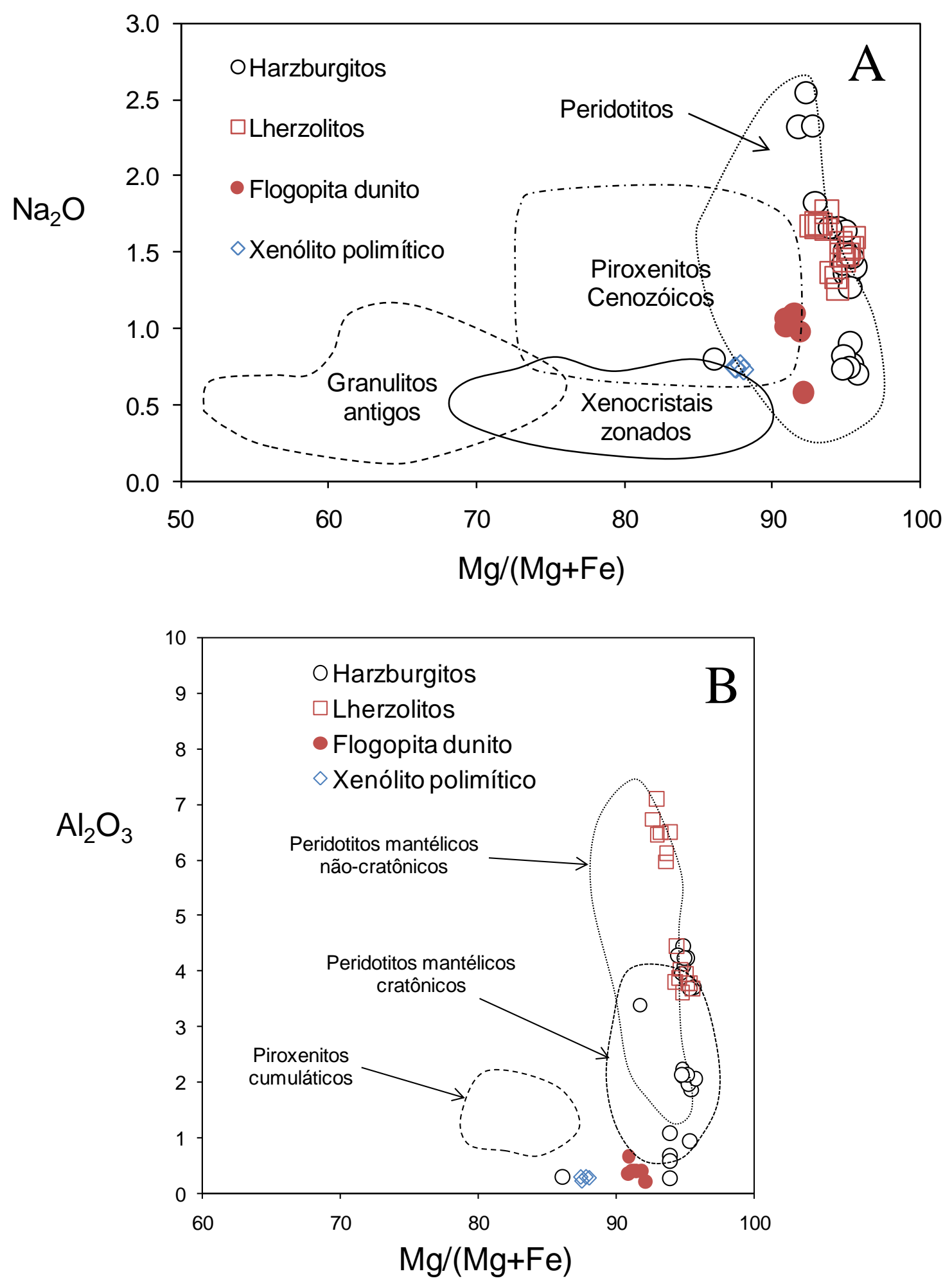

Figura 26- A)Diagrama $\mathrm{Na}_{2} \mathrm{O}$ (\%wt.) versus \#Mg de clinopiroxênio de xenólitos do Kimberlito Indaiá. B) Diagrama $\mathrm{Al}_{2} \mathrm{O}_{3}(\%$ wt.) versus \#Mg de clinopiroxênio dos xenólitos estudados (Zhang et al., 2010). 


\subsection{Espinélios}

Este grupo de minerais, apesar de ser pouco abundante, é freqüente em todas as amostras. É dentre os grupos minerais estudados aquele com maior variação composicional, como mostra a Tabela 8. Ocorrem tanto como fase primária, na forma de grãos isolados em contato com olivina, ortopiroxênio e clinopiroxênio, como também como fases secundárias associadas a agregados micáceos e clinopiroxênio, provenientes de processos de metassomatismo.

No harzburgito com textura grossa da amostra In1/9 o espinélio varia de 0,22-0,25 em $\mathrm{Fe}^{2} /\left(\mathrm{Fe}^{2}+\mathrm{Mg}\right)$ e $0,13-0,17$ em $\mathrm{Cr} /(\mathrm{Cr}+\mathrm{Al})$. Nos lherzolitos com textura grossa o valor é similar, com $\mathrm{Fe}^{2} /\left(\mathrm{Fe}^{2}+\mathrm{Mg}\right)$ de 0,23-0,31 e $\mathrm{Cr} /(\mathrm{Cr}+\mathrm{Al})$ de 0,16-0,31. No harzburgito com textura grossa correspondente à amostra In1/20b a cromita associada aos bolsões de flogopita tem $\mathrm{Fe}^{2} /\left(\mathrm{Fe}^{2}+\mathrm{Mg}\right)$ de 0,30-0,32 e $\mathrm{Cr} /(\mathrm{Cr}+\mathrm{Al})$ de 0,75-0,76. Nos harzburgitos e dunitos com textura granoblástica, das amostras In1/3 e In1/24a, a variação das razões $\mathrm{Fe}^{2} /\left(\mathrm{Fe}^{2}+\mathrm{Mg}\right)$ e $\mathrm{Cr} /(\mathrm{Cr}+\mathrm{Al})$ é respectivamente 0,42-0,47 e 0,48-0,52. No flogopita dunito da amostra In1/2 a cromita dos bolsões de flogopita tem razão $\mathrm{Fe}^{2} /\left(\mathrm{Fe}^{2}+\mathrm{Mg}\right)$ é 0,52-0,62 e $\mathrm{Cr} /(\mathrm{Cr}+\mathrm{Al})$ é 0,94-0,98. No mica peridotito representado pela amostra In1/24b a magnetita apresenta $\mathrm{Fe}^{2} /\left(\mathrm{Fe}^{2}+\mathrm{Mg}\right)$ de $0,61-0,79$ e $\mathrm{Cr} /(\mathrm{Cr}+\mathrm{Al})$ de 0,940,95. No xenólito polimítico da amostra In1/6 a magnetita presente apresenta $\mathrm{Fe}^{2} /\left(\mathrm{Fe}^{2}+\mathrm{Mg}\right)$ de 0,64 e $\mathrm{Cr} /(\mathrm{Cr}+\mathrm{Al})$ de $0,26-0,5$.

Os espinélios dos harzburgitos, lherzolitos e dunitos têm composições químicas que se projetam no campo dos xenólitos de kimberlitos definido por Mitchell (1986), enquanto os espinélios do flogopita dunito e mica piroxenitoprojetam-se predominantemente fora dos campos definidos pelo mesmo autor, como mostra a Figura 27. Além disto, é possível notar na Tabela 8 que as amostras que sofreram metassomatismo têm maiores quantidades de $\mathrm{Fe}^{2}, \mathrm{Fe}^{3}$ e Ti, em concordância com as observações de Haggerty (1995). 
Tabela 8- Análises químicas de minerais do grupo dos espinélios, de xenólitos da intrusão Indaiá 1, obtidas por meio da microssonda eletrônica.

\begin{tabular}{|c|c|c|c|c|c|c|c|c|c|c|c|c|c|c|c|}
\hline \multirow[b]{2}{*}{2} & \multicolumn{6}{|c|}{ Flogopita dunito } & \multicolumn{3}{|c|}{ Harzburgito com textura granoblástica } & \multicolumn{2}{|c|}{ Xenólito polimítico } & \multicolumn{4}{|c|}{ Harzburgito com espinélio e textura gross } \\
\hline & $2 / 1$ & $2 / 2$ & $2 / 3$ & $2 / 4$ & $2 / 5$ & $2 / 6$ & $3 / 1$ & $3 / 2$ & $3 / 3$ & $6 / 1$ & $6 / 2$ & $9 / 1$ & 9/2 & $9 / 3$ & 9/4 \\
\hline $\mathrm{SiO}_{2}^{2}$ & 0,05 & 0,07 & 0,06 & 0,05 & 0,02 & 0,04 & 0,02 & 0,03 & 0,01 & 0,04 & 0,05 & 0,00 & 0,02 & 0,00 & 0,02 \\
\hline $\mathrm{TiO}_{2}^{2} \mathrm{O}_{3}^{3}$ & 4,47 & 4,51 & 4,64 & 4,94 & 15,12 & 4,93 & 0,10 & 0,09 & 0,08 & 18,04 & 18,26 & 0,04 & 0,05 & 0,09 & 0,05 \\
\hline $\mathrm{Al}^{2} \mathrm{O}^{3}$ & 2,10 & 2,12 & 2,08 & 2,01 & 0,16 & 2,05 & 28,31 & 25,81 & 26,58 & 0,77 & 1,36 & 51,71 & 55,10 & 53,41 & 51,23 \\
\hline $\mathrm{Fe} \mathrm{O}$ & 10,51 & 10,65 & 9,79 & 10,59 & 33,74 & 10,40 & 1,13 & 2,10 & 0,89 & 36,80 & 35,50 & 2,48 & 1,84 & 2,54 & 1,29 \\
\hline $\mathrm{FeO}$ & 22,90 & 22,96 & 22,80 & 20,45 & 28,90 & 23,24 & 17,12 & 16,21 & 17,19 & 31,92 & 30,91 & 10,16 & 10,21 & 10,27 & 11,12 \\
\hline $\mathrm{MnO}$ & 0,25 & 0,25 & 0,21 & 0,33 & 0,53 & 0,26 & 0,20 & 0,20 & 0,22 & 0,81 & 0,85 & 0,07 & 0,10 & 0,10 & 0,07 \\
\hline $\mathrm{MgO}$ & 8,72 & 8,74 & 8,74 & 10,27 & 9,87 & 8,91 & 12,43 & 12,47 & 11,68 & 9,72 & 9,76 & 19,44 & 19,80 & 19,56 & 18,45 \\
\hline $\mathrm{CaO}_{2}^{2}$ & 0,04 & 0,02 & 0,00 & 0,15 & 0,56 & 0,01 & 0,00 & 0,00 & 0,01 & 0,07 & 0,73 & 0,00 & 0,00 & 0,00 & 0,01 \\
\hline $\mathrm{NaO}^{2} \mathrm{O}^{3}$ & n.a. & n.a. & n.a. & 0,00 & 0,06 & 0,00 & 0,00 & 0,00 & 0,00 & n.a. & n.a. & 0,00 & 0,00 & 0,00 & 0,00 \\
\hline $\mathrm{CrO}$ & 51,71 & 51,55 & 51,56 & 51,28 & 11,20 & 51,40 & 40,31 & 41,12 & 40,68 & 1,15 & 0,72 & 15,73 & 12,67 & 13,82 & 15,88 \\
\hline $\mathrm{ZnO}$ & 0,09 & 0,13 & 0,15 & 0,17 & 0,12 & n.a. & 0,29 & 0,19 & 0,31 & 0,05 & 0,15 & 0,21 & 0,19 & 0,27 & 0,28 \\
\hline $\mathrm{NiO}$ & 0,20 & 0,21 & 0,22 & 0,23 & 0,70 & n.a. & 0,03 & 0,03 & 0,06 & 0,25 & 0,23 & 0,26 & 0,31 & 0,31 & 0,25 \\
\hline Total & 101,02 & 101,21 & 100,25 & 100,46 & 100,98 & 101,24 & 99,94 & 98,25 & 97,70 & 99,61 & 98,51 & 100,09 & 100,30 & 100,36 & 98,66 \\
\hline \multicolumn{16}{|c|}{ Número de cátions com base em 4 átomos de oxigênio } \\
\hline $\mathrm{Si}$ & 0,002 & 0,002 & 0,002 & 0,002 & 0,001 & 0,001 & 0,001 & 0,001 & 0,000 & 0,001 & 0,002 & 0,000 & 0,000 & 0,000 & 0,001 \\
\hline $\mathrm{Ti}$ & 0,116 & 0,116 & 0,121 & 0,127 & 0,395 & 0,127 & 0,002 & 0,002 & 0,002 & 0,478 & 0,486 & 0,001 & 0,001 & 0,002 & 0,001 \\
\hline $\mathrm{Al}$ & 0,085 & 0,086 & 0,085 & 0,081 & 0,007 & 0,083 & 1,007 & 0,940 & 0,974 & 0,032 & 0,057 & 1,616 & 1,696 & 1,655 & 1,629 \\
\hline $\mathrm{Fe}^{3}$ & 0,272 & 0,275 & 0,255 & 0,272 & 0,882 & 0,268 & 0,026 & 0,049 & 0,021 & 0,974 & 0,945 & 0,049 & 0,036 & 0,050 & 0,026 \\
\hline $\mathrm{Fe}^{2}$ & 0,658 & 0,659 & 0,660 & 0,585 & 0,840 & 0,666 & 0,432 & 0,419 & 0,447 & 0,939 & 0,914 & 0,225 & 0,223 & 0,226 & 0,251 \\
\hline Mn & 0,007 & 0,007 & 0,006 & 0,009 & 0,016 & 0,008 & 0,005 & 0,005 & 0,006 & 0,024 & 0,025 & 0,002 & 0,002 & 0,002 & 0,002 \\
\hline $\mathrm{Mg}$ & 0,447 & 0,447 & 0,451 & 0,523 & 0,511 & 0,455 & 0,559 & 0,574 & 0,542 & 0,510 & 0,515 & 0,769 & 0,771 & 0,767 & 0,742 \\
\hline $\mathrm{Ca}$ & 0,001 & 0,001 & 0,000 & 0,005 & 0,021 & 0,000 & 0,000 & 0,000 & 0,000 & 0,003 & 0,028 & 0,000 & 0,000 & 0,000 & 0,000 \\
\hline $\mathrm{Na}$ & 0,000 & 0,000 & 0,000 & 0,000 & 0,004 & 0,000 & 0,000 & 0,000 & 0,000 & 0,000 & 0,000 & 0,000 & 0,000 & 0,000 & 0,000 \\
\hline $\mathrm{Cr}$ & 1,406 & 1,399 & 1,411 & 1,386 & 0,308 & 1,392 & 0,961 & 1,005 & 1,000 & 0,032 & 0,020 & 0,330 & 0,262 & 0,287 & 0,339 \\
\hline $\mathrm{Zn}$ & 0,002 & 0,003 & 0,004 & 0,004 & 0,003 & n.a. & 0,007 & 0,004 & 0,007 & 0,001 & 0,004 & 0,004 & 0,004 & 0,005 & 0,006 \\
\hline $\mathrm{Ni}$ & 0,005 & 0,006 & 0,006 & 0,006 & 0,020 & n.a. & 0,001 & 0,001 & 0,001 & 0,007 & 0,006 & 0,006 & 0,006 & 0,007 & 0,005 \\
\hline Total & 3,001 & 3,001 & 3,002 & 3,002 & 3,007 & 3,001 & 3,001 & 3,001 & 3,001 & 3,002 & 3,002 & 3,001 & 3,001 & 3,001 & 3,001 \\
\hline $\mathrm{Fe} 2 /(\mathrm{Fe} 2+\mathrm{Mg})$ & 0,596 & 0,596 & 0,594 & 0,528 & 0,622 & 0,594 & 0,436 & 0,422 & 0,452 & 0,648 & 0,640 & 0,227 & 0,224 & 0,228 & 0,253 \\
\hline $\mathrm{Cr} /(\mathrm{Cr}+\mathrm{Al})$ & 0,943 & 0,942 & 0,943 & 0,945 & 0,979 & 0,944 & 0,488 & 0,517 & 0,507 & 0,501 & 0,260 & 0,169 & 0,134 & 0,148 & 0,172 \\
\hline $\mathrm{hg} /$ (Mg+Fetotal) & 0,324 & 0,324 & 0,330 & 0,379 & 0,229 & 0,328 & 0,550 & 0,551 & 0,536 & 0,210 & 0,217 & 0,737 & 0,748 & 0,735 & 0,728 \\
\hline
\end{tabular}


Tabela 8- Continuação.

\begin{tabular}{|c|c|c|c|c|c|c|c|c|c|c|c|c|c|c|}
\hline \multirow[b]{2}{*}{${ }^{2}$} & \multicolumn{2}{|c|}{ Lherzolito com espinélio } & \multicolumn{2}{|c|}{ Lherzolito com espinélio } & \multicolumn{4}{|c|}{ Harzburgito com flogopita } & \multicolumn{4}{|c|}{ Dunito com cromita e textura granoblástica } & \multicolumn{2}{|c|}{ Mica piroxenits } \\
\hline & $13 \mathrm{a} / 1$ & $13 \mathrm{a} / 2$ & $14 \mathrm{a} / 1$ & $14 \mathrm{a} / 2$ & $20 \mathrm{~b} / 1$ & $20 \mathrm{~b} / 2$ & $20 \mathrm{~b} / 3$ & $20 \mathrm{~b} / 4$ & $24 \mathrm{a} / 1$ & $24 \mathrm{a} / 2$ & $24 \mathrm{a} / 3$ & $24 \mathrm{a} / 4$ & $24 \mathrm{~b} / 1$ & $24 \mathrm{~b} / 2$ \\
\hline $\mathrm{SiO}_{3}^{2}$ & 0,02 & 0,03 & 0,00 & 0,02 & 0,11 & 0,08 & 0,09 & 0,05 & 0,00 & 0,03 & 0,02 & 0,00 & 0,41 & 0,12 \\
\hline $\mathrm{TiO}^{2}$ & 0,00 & 0,12 & 0,00 & 0,07 & 1,64 & 1,31 & 1,42 & 1,75 & 0,32 & 0,23 & 0,19 & 0,10 & 12,75 & 10,52 \\
\hline $\mathrm{Al}^{2} \mathrm{O}^{3}$ & 41,35 & 43,37 & 51,24 & 51,67 & 11,78 & 11,97 & 12,04 & 11,08 & 25,76 & 26,49 & 26,10 & 26,35 & 0,15 & 0,17 \\
\hline $\mathrm{Fe} O$ & 1,26 & 0,57 & 2,38 & 1,28 & 3,76 & 3,87 & 3,76 & 4,49 & 1,97 & 0,85 & 1,60 & 1,07 & 45,25 & 48,84 \\
\hline $\mathrm{FeO}$ & 13,36 & 13,25 & 10,18 & 11,29 & 12,10 & 12,35 & 12,42 & 11,57 & 18,22 & 17,72 & 17,85 & 17,95 & 27,14 & 27,31 \\
\hline $\mathrm{MnO}$ & 0,16 & 0,13 & 0,13 & 0,11 & 0,10 & 0,09 & 0,09 & 0,10 & 0,23 & 0,18 & 0,18 & 0,22 & 0,78 & 0,55 \\
\hline $\mathrm{MgO}$ & 16,46 & 16,82 & 19,01 & 18,51 & 14,77 & 14,47 & 14,61 & 14,92 & 11,50 & 12,02 & 12,03 & 12,01 & 9,65 & 8,53 \\
\hline $\mathrm{CaO}_{2}^{2}$ & 0,00 & 0,00 & 0,00 & 0,01 & 0,01 & 0,03 & 0,04 & 0,04 & 0,01 & 0,02 & 0,00 & 0,00 & 0,73 & 0,58 \\
\hline $\mathrm{NaO}^{2} \mathrm{z}^{3}$ & 0,00 & 0,00 & 0,00 & 0,00 & 0,00 & 0,00 & 0,00 & 0,00 & 0,00 & 0,00 & 0,00 & 0,00 & n.a. & 0,03 \\
\hline $\mathrm{CrO}$ & 28,30 & 26,36 & 15,19 & 15,75 & 53,71 & 54,02 & 54,28 & 53,52 & 41,77 & 42,44 & 42,80 & 43,76 & 3,58 & 5,34 \\
\hline $\mathrm{ZnO}$ & 0,28 & 0,23 & 0,18 & 0,21 & 0,08 & 0,01 & 0,01 & 0,11 & 0,44 & 0,27 & 0,27 & 0,39 & 0,00 & 0,01 \\
\hline $\mathrm{NiO}$ & 0,17 & 0,17 & 0,28 & 0,29 & 0,11 & 0,18 & 0,17 & 0,19 & 0,07 & 0,04 & 0,07 & 0,04 & 0,14 & 0,08 \\
\hline Total & 101,36 & 101,04 & 98,59 & 99,22 & 98,17 & 98,38 & 98,94 & 97,82 & 100,30 & 100,27 & 101,11 & 101,88 & 100,58 & 102,08 \\
\hline \multicolumn{15}{|c|}{ Número de cátions com base em 4 átomos de oxigênio } \\
\hline $\mathrm{Si}$ & 0,000 & 0,001 & 0,000 & 0,000 & 0,004 & 0,003 & 0,003 & 0,002 & 0,000 & 0,001 & 0,000 & 0,000 & 0,014 & 0,004 \\
\hline $\mathrm{Ti}$ & 0,000 & 0,002 & 0,000 & 0,001 & 0,040 & 0,032 & 0,034 & 0,043 & 0,007 & 0,005 & 0,004 & 0,002 & 0,336 & 0,276 \\
\hline $\mathrm{Al}$ & 1,351 & 1,406 & 1,626 & 1,633 & 0,449 & 0,455 & 0,455 & 0,424 & 0,929 & 0,948 & 0,930 & 0,932 & 0,006 & 0,007 \\
\hline $\mathrm{Fe}^{3}$ & 0,026 & 0,012 & 0,048 & 0,026 & 0,091 & 0,094 & 0,091 & 0,110 & 0,045 & 0,019 & 0,037 & 0,024 & 1,192 & 1,283 \\
\hline $\mathrm{Fe}^{2}$ & 0,310 & 0,305 & 0,229 & 0,253 & 0,327 & 0,333 & 0,333 & 0,314 & 0,466 & 0,450 & 0,451 & 0,451 & 0,795 & 0,797 \\
\hline $\mathrm{Mn}$ & 0,004 & 0,003 & 0,003 & 0,002 & 0,003 & 0,003 & 0,002 & 0,003 & 0,006 & 0,005 & 0,005 & 0,006 & 0,023 & 0,016 \\
\hline $\mathrm{Mg}$ & 0,680 & 0,690 & 0,763 & 0,740 & 0,711 & 0,696 & 0,699 & 0,722 & 0,524 & 0,544 & 0,542 & 0,537 & 0,504 & 0,444 \\
\hline $\mathrm{Ca}$ & 0,000 & 0,000 & 0,000 & 0,000 & 0,000 & 0,001 & 0,001 & 0,001 & 0,000 & 0,001 & 0,000 & 0,000 & 0,027 & 0,022 \\
\hline $\mathrm{Na}$ & 0,000 & 0,000 & 0,000 & 0,000 & 0,000 & 0,000 & 0,000 & 0,000 & 0,000 & 0,000 & 0,000 & 0,000 & 0,000 & 0,002 \\
\hline $\mathrm{Cr}$ & 0,620 & 0,573 & 0,323 & 0,334 & 1,372 & 1,379 & 1,377 & 1,375 & 1,010 & 1,019 & 1,023 & 1,038 & 0,099 & 0,147 \\
\hline $\mathrm{Zn}$ & 0,006 & 0,005 & 0,004 & 0,004 & 0,002 & 0,000 & 0,000 & 0,003 & 0,010 & 0,006 & 0,006 & 0,009 & 0,000 & 0,000 \\
\hline $\mathrm{Ni}$ & 0,004 & 0,004 & 0,006 & 0,006 & 0,003 & 0,005 & 0,004 & 0,005 & 0,002 & 0,001 & 0,002 & 0,001 & 0,004 & 0,002 \\
\hline Total & 3,001 & 3,001 & 3,002 & 3,002 & 3,001 & 3,001 & 3,001 & 3,001 & 3,000 & 3,000 & 3,000 & 3,000 & 3,001 & 3,002 \\
\hline $\mathrm{Fe} 2 /(\mathrm{Fe} 2+\mathrm{Mg})$ & 0,313 & 0,307 & 0,231 & 0,255 & 0,315 & 0,324 & 0,323 & 0,303 & 0,471 & 0,453 & 0,454 & 0,456 & 0,612 & 0,642 \\
\hline $\mathrm{Cr} /(\mathrm{Cr}+\mathrm{Al})$ & 0,315 & 0,290 & 0,166 & 0,170 & 0,754 & 0,752 & 0,752 & 0,764 & 0,521 & 0,518 & 0,524 & 0,527 & 0,940 & 0,955 \\
\hline $\mathrm{Mg} /(\mathrm{Mg}+\mathrm{Fetotal})$ & 0,67 & 0,69 & 0,73 & 0,73 & 0,63 & 0,62 & 0,62 & 0,63 & 0,51 & 0,54 & 0,53 & 0,53 & 0,20 & 0,18 \\
\hline
\end{tabular}




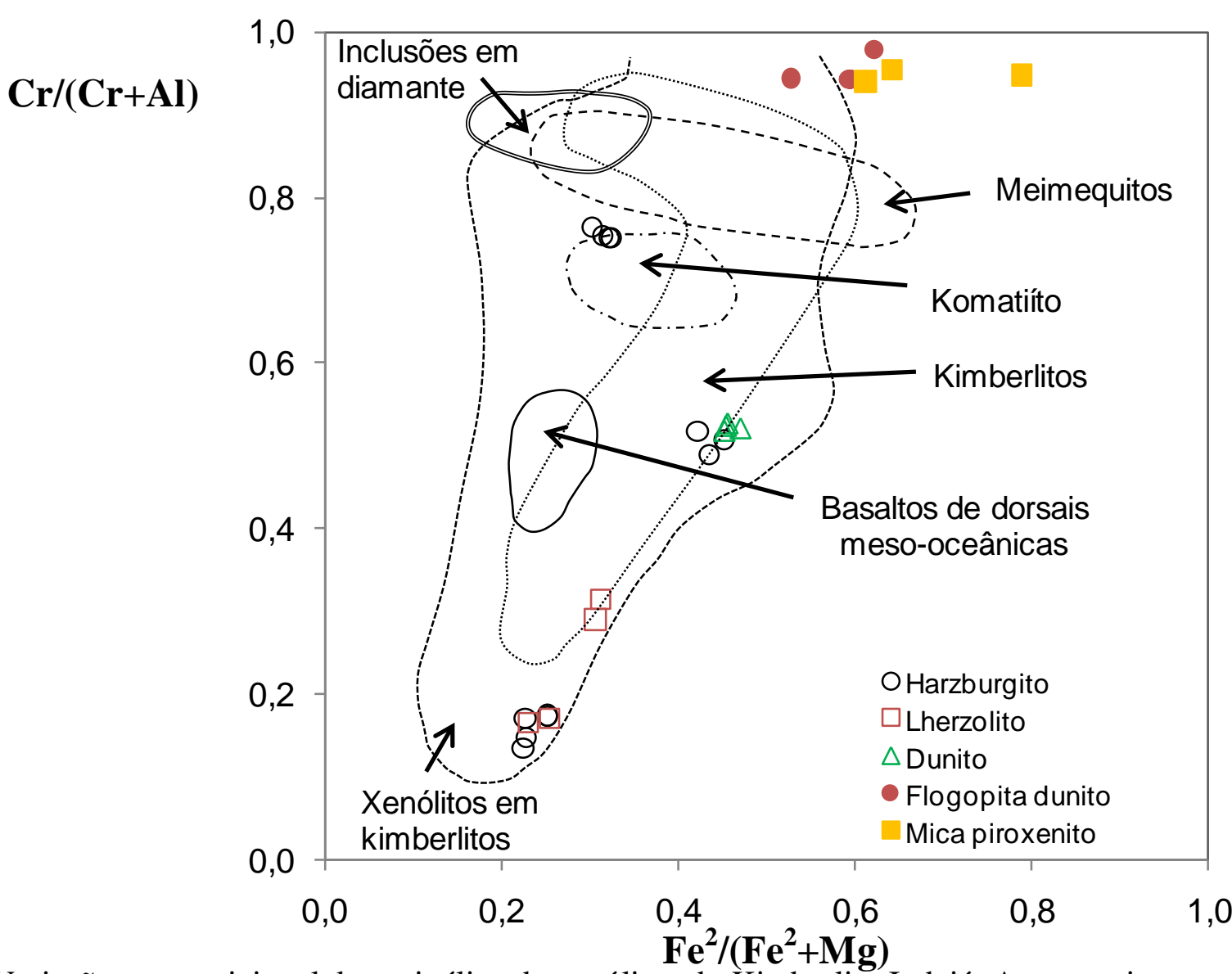

Figura 27- Variação composicional de espinélios de xenólitos do Kimberlito Indaiá. A magnetita presente no xenólito polimítico não foi projetada no diagrama devido aos baixos valores para os elementos representados. 


\subsection{Flogopita}

A flogopita é freqüente nas amostras de xenólitos, e ocorre como fase secundária nos peridotitos e em mica piroxenitos, como produto de metassomatismo mantélico. As análises químicas deste mineral estão na Tabela 9.

No flogopita dunito da amostra In1/2 e nos bolsões de flogopita do harzburgito da amostra In1/20b Mg/(Mg+Fe) fica entre 0,90-0,94, $\mathrm{TiO}_{2}$ 1,7-2,5\% e F 0,2-0,7\%. Na amostra de harzburgito de código In1/1 a flogopita intersticial têm valores de $\mathrm{Mg} /(\mathrm{Mg}+\mathrm{Fe})$ 0,84-0,86, $\mathrm{TiO}_{2}$ 5,3-5,5\% e F 0,5-0,7\%. Já no mica piroxenito da amostra In1/24b bem como no xenólito polimítico da amostra In1/6 a razão $\mathrm{Mg} /(\mathrm{Mg}+\mathrm{Fe})$ varia entre 0,85-0,87, $\mathrm{TiO}_{2}$ 3,0-3,2\% e F 0,2$0,9 \%$.

As micas estudadas têm composição correspondente à flogopita, segundo a projeção no diagrama de Mitchell (1986), da Figura 27. As flogopitas mais ricas em Al são as presentes nos harzburgitos; elas são sucessivamente menos ricas em Al nos mica piroxenitos, flogopita dunito e peridotito polimítico. Segundo o diagrama de Grégoire et al. (2002) da Figura 29, as micas estudadas correspondem às encontradas nos xenólitos MARID, pela composição $\mathrm{Al}_{2} \mathrm{O}_{3}$ vs. $\mathrm{Mg} /(\mathrm{Mg}+\mathrm{Fe})$. As micas do harzburgito com textura grossa da amostra In1/20 por sua vez têm composição que projeta no campo dos PIC.

Carswell (1975) definiu os tipos primário e secundário para flogopita em estudo de granada peridotitos sul africanas. O primeiro tipo corresponde à placas grandes (2-3 mm) sem evidências texturais de desequilíbrio com outras fases primárias, enquanto o tipo secundário, segundo o mesmo autor, foi identificado nas bordas de granadas, como produto de alteração. Dawson (1987) descreveu pela primeira vez a suíte de xenólitos MARID (mica+anfibólio+rutilo+ilmenita+diopsídio), e atribuiu sua gênese a processos de metassomatismo mantélico. Assumindo que os cristais de flogopita presentes nos peridotitos do Kimberlito Indaiá ocorrem sob a forma de bolsões em agregados com minerais opacos, é possível dizer que estas micas são decorrentes de um processo de metassomatismo, ou seja, elas têm uma origem secundária. 
Tabela 9- Análises químicas de flogopita de xenólitos da intrusão Indaiá 1, obtidas por meio da microssonda.

\begin{tabular}{|c|c|c|c|c|c|c|c|c|c|c|c|c|c|}
\hline \multirow[b]{2}{*}{2} & \multicolumn{2}{|c|}{ Harzburgito com textura grossa } & \multicolumn{6}{|c|}{ Flogopita dunito } & \multicolumn{5}{|c|}{ Xenólito polimítico } \\
\hline & $1 / 1$ & $1 / 2$ & $2 / 1$ & $2 / 2$ & $2 / 3$ & $2 / 4$ & $2 / 5$ & $2 / 6$ & $6 / 1$ & $6 / 2$ & $6 / 3$ & $6 / 4$ & $6 / 5$ \\
\hline $\mathrm{SiO}^{2}$ & 40,84 & 39,89 & 40,86 & 40,72 & 40,51 & 40,34 & 40,75 & 40,41 & 41,38 & 41,37 & 41,58 & 41,42 & 41,74 \\
\hline $\mathrm{T}_{1}^{2} \mathrm{O}^{3}$ & 5,53 & 5,37 & 2,01 & 1,97 & 1,72 & 2,19 & 1,97 & 2,13 & 1,81 & 1,42 & 1,51 & 1,37 & 1,51 \\
\hline $\mathrm{AlO}$ & 10,78 & 12,35 & 11,49 & 11,59 & 11,60 & 11,61 & 11,62 & 11,55 & 11,06 & 10,98 & 11,18 & 10,96 & 11,03 \\
\hline $\mathrm{FeO}$ & 5,99 & 6,64 & 4,38 & 4,35 & 4,64 & 4,42 & 4,43 & 4,75 & 6,36 & 6,41 & 6,48 & 6,60 & 6,51 \\
\hline $\mathrm{MnO}$ & 0,02 & 0,03 & 0,02 & 0,04 & 0,02 & 0,05 & 0,01 & 0,01 & 0,02 & 0,05 & 0,01 & 0,03 & 0,03 \\
\hline $\mathrm{MgO}$ & 22,02 & 20,57 & 24,06 & 24,19 & 24,04 & 24,09 & 24,05 & 24,11 & 24,32 & 24,23 & 24,63 & 24,36 & 24,44 \\
\hline $\mathrm{CaO}$ & 0,00 & 0,07 & 0,03 & 0,07 & 0,02 & 0,02 & 0,00 & 0,01 & 0,05 & 0,03 & 0,05 & 0,03 & 0,00 \\
\hline $\mathrm{BaO}^{2}$ & 0,01 & 0,27 & 0,00 & 0,08 & 0,00 & 0,00 & 0,00 & 0,02 & 0,02 & 0,00 & 0,04 & 0,03 & 0,05 \\
\hline $\mathrm{NaO}$ & 0,38 & 0,24 & 0,15 & 0,05 & 0,09 & 0,12 & 0,04 & 0,07 & 0,22 & 0,22 & 0,10 & 0,20 & 0,09 \\
\hline $\mathrm{K} 2 \mathrm{O}$ & 10,42 & 10,62 & 10,98 & 10,75 & 10,67 & 10,60 & 10,71 & 10,88 & 10,61 & 10,80 & 10,78 & 10,85 & 10,81 \\
\hline $\mathrm{Cl}$ & 0,03 & 0,03 & 0,01 & 0,03 & 0,01 & 0,02 & 0,01 & 0,00 & 0,03 & 0,02 & 0,04 & 0,01 & 0,00 \\
\hline $\mathrm{F}_{\mathrm{F}}^{3}$ & 0,67 & 0,50 & 0,61 & 0,38 & 0,53 & 0,46 & 0,34 & 0,61 & 0,90 & 0,42 & 0,71 & 0,37 & 0,30 \\
\hline $\mathrm{CrO}$ & n.a. & n.a. & n.a. & n.a. & n.a. & n.a. & n.a. & n.a. & 0,17 & 0,18 & 0,21 & 0,13 & 0,21 \\
\hline \multirow[t]{2}{*}{ Total } & 96,68 & 96,57 & 94,58 & 94,22 & 93,85 & 93,90 & 93,93 & 94,55 & 96,94 & 96,13 & 97,32 & 96,35 & 96,72 \\
\hline & \multicolumn{13}{|c|}{ Número de cátions com base em 22 átomos de oxigênio } \\
\hline $\mathrm{Si}$ & 5,837 & 5,731 & 5,923 & 5,908 & 5,911 & 5,876 & 5,920 & 5,872 & 5,917 & 5,943 & 5,916 & 5,939 & 5,947 \\
\hline $\mathrm{Ti}$ & 0,594 & 0,580 & 0,219 & 0,215 & 0,189 & 0,240 & 0,216 & 0,233 & 0,195 & 0,154 & 0,161 & 0,147 & 0,162 \\
\hline $\mathrm{Al}$ & 1,816 & 2,092 & 1,962 & 1,982 & 1,996 & 1,992 & 1,989 & 1,978 & 1,864 & 1,858 & 1,875 & 1,852 & 1,852 \\
\hline $\mathrm{Fe}^{2}$ & 0,716 & 0,798 & 0,530 & 0,528 & 0,566 & 0,539 & 0,538 & 0,577 & 0,761 & 0,770 & 0,771 & 0,791 & 0,776 \\
\hline $\mathrm{Mn}$ & 0,003 & 0,004 & 0,003 & 0,005 & 0,002 & 0,007 & 0,001 & 0,001 & 0,002 & 0,006 & 0,002 & 0,003 & 0,004 \\
\hline $\mathrm{Mg}$ & 4,691 & 4,406 & 5,200 & 5,233 & 5,229 & 5,232 & 5,210 & 5,223 & 5,185 & 5,189 & 5,223 & 5,208 & 5,191 \\
\hline $\mathrm{Ca}$ & 0,000 & 0,010 & 0,005 & 0,011 & 0,003 & 0,003 & 0,000 & 0,002 & 0,007 & 0,004 & 0,008 & 0,005 & 0,000 \\
\hline $\mathrm{Ba}$ & 0,001 & 0,015 & 0,000 & 0,004 & 0,000 & 0,000 & 0,000 & 0,001 & 0,001 & 0,000 & 0,002 & 0,002 & 0,003 \\
\hline $\mathrm{Na}$ & 0,104 & 0,066 & 0,041 & 0,015 & 0,024 & 0,033 & 0,012 & 0,020 & 0,061 & 0,062 & 0,026 & 0,054 & 0,024 \\
\hline $\mathrm{K}$ & 1,900 & 1,947 & 2,031 & 1,990 & 1,987 & 1,969 & 1,984 & 2,017 & 1,935 & 1,979 & 1,956 & 1,985 & 1,965 \\
\hline $\mathrm{Cl}$ & 0,006 & 0,008 & 0,002 & 0,007 & 0,004 & 0,005 & 0,002 & 0,001 & 0,008 & 0,004 & 0,009 & 0,002 & 0,000 \\
\hline $\mathrm{F}$ & 0,301 & 0,227 & 0,279 & 0,174 & 0,243 & 0,210 & 0,157 & 0,278 & 0,406 & 0,192 & 0,319 & 0,168 & 0,137 \\
\hline $\mathrm{Cr}$ & n.a. & n.a. & n.a. & n.a. & n.a. & n.a. & n.a. & n.a. & 0,019 & 0,020 & 0,024 & 0,015 & 0,024 \\
\hline Total & 15,969 & 15,883 & 16,195 & 16,071 & 16,154 & 16,104 & 16,028 & 16,204 & 16,360 & 16,181 & 16,292 & 16,171 & 16,085 \\
\hline $\mathrm{Mg} /(\mathrm{Mg}+\mathrm{Fe})$ & 0,868 & 0,847 & 0,907 & 0,908 & 0,902 & 0,907 & 0,906 & 0,901 & 0,872 & 0,871 & 0,871 & 0,868 & 0,870 \\
\hline
\end{tabular}


Tabela 9- Continuação.

\begin{tabular}{|c|c|c|c|c|c|c|c|c|c|c|c|c|c|}
\hline \multirow[b]{2}{*}{2} & \multicolumn{2}{|c|}{ Xenólito polimítico } & \multicolumn{6}{|c|}{ Harzburgito com flogopita } & \multicolumn{5}{|c|}{ Mica piroxenito } \\
\hline & $6 / 7$ & $6 / 8$ & $20 \mathrm{~b} / 1$ & $20 \mathrm{~b} / 2$ & $20 \mathrm{~b} / 3$ & $20 \mathrm{~b} / 4$ & $20 \mathrm{~b} / 5$ & $20 \mathrm{~b} / 6$ & $24 \mathrm{~b} / 1$ & $24 \mathrm{~b} / 2$ & $24 \mathrm{~b} / 3$ & $24 \mathrm{~b} / 4$ & $24 \mathrm{~b} / 5$ \\
\hline $\mathrm{SiO}_{3}^{2}$ & 41,24 & 41,57 & 39,45 & 39,79 & 38,74 & 39,68 & 39,22 & 38,05 & 40,37 & 39,86 & 41,09 & 40,87 & 40,53 \\
\hline $\mathrm{TiO}^{2}$ & 1,44 & 1,40 & 2,54 & 2,09 & 2,40 & 2,34 & 2,01 & 2,35 & 3,24 & 3,25 & 3,08 & 3,17 & 3,14 \\
\hline $\mathrm{AlO}$ & 10,75 & 11,11 & 14,13 & 13,98 & 14,05 & 14,26 & 13,97 & 13,66 & 11,94 & 12,13 & 11,91 & 12,17 & 12,14 \\
\hline $\mathrm{FeO}$ & 6,29 & 6,01 & 2,74 & 2,75 & 2,83 & 2,91 & 2,77 & 2,98 & 5,93 & 5,75 & 5,91 & 5,73 & 5,83 \\
\hline $\mathrm{MnO}$ & 0,03 & 0,02 & 0,01 & 0,06 & 0,00 & 0,05 & 0,01 & 0,01 & 0,05 & 0,00 & 0,03 & 0,01 & 0,02 \\
\hline $\mathrm{MgO}$ & 24,54 & 24,21 & 22,82 & 22,86 & 23,10 & 23,11 & 23,28 & 23,02 & 22,52 & 22,81 & 23,18 & 22,91 & 22,89 \\
\hline $\mathrm{CaO}$ & 0,02 & 0,02 & 0,03 & 0,01 & 0,03 & 0,01 & 0,01 & 0,03 & 0,02 & 0,06 & 0,00 & 0,00 & 0,01 \\
\hline $\mathrm{BaO}^{2}$ & 0,00 & 0,00 & 0,14 & 0,26 & 0,16 & 0,14 & 0,15 & 0,13 & 0,09 & 0,04 & 0,12 & 0,03 & 0,03 \\
\hline $\mathrm{NaO}$ & 0,08 & 0,16 & 0,19 & 0,21 & 0,18 & 0,21 & 0,22 & 0,23 & 0,07 & 0,08 & 0,03 & 0,04 & 0,12 \\
\hline K2O & 10,78 & 10,67 & 10,48 & 10,52 & 10,42 & 10,52 & 10,14 & 10,52 & 10,59 & 10,64 & 10,70 & 10,62 & 10,72 \\
\hline $\mathrm{Cl}$ & 0,02 & 0,03 & 0,00 & 0,00 & 0,03 & 0,01 & 0,02 & 0,01 & 0,00 & 0,03 & 0,00 & 0,05 & 0,02 \\
\hline $\mathrm{F}^{3}$ & 0,48 & 0,50 & 0,39 & 0,39 & 0,24 & 0,31 & 0,19 & 0,73 & 0,42 & 0,80 & 0,20 & 0,76 & 0,53 \\
\hline $\mathrm{CrO}$ & 0,19 & 0,19 & n.a. & n.a. & n.a. & 2,09 & 2,05 & 2,19 & 0,44 & 0,39 & 0,33 & 0,36 & 0,42 \\
\hline \multirow[t]{2}{*}{ Total } & 95,84 & 95,88 & 92,92 & 92,93 & 92,17 & 95,65 & 94,03 & 93,93 & 95,67 & 95,85 & 96,57 & 96,70 & 96,39 \\
\hline & \multicolumn{13}{|c|}{ Número de cátions com base em 22 átomos de oxigênio } \\
\hline $\mathrm{Si}$ & 5,941 & 5,969 & 5,749 & 5,802 & 5,695 & 5,651 & 5,663 & 5,573 & 5,817 & 5,759 & 5,844 & 5,830 & 5,801 \\
\hline $\mathrm{Ti}$ & 0,156 & 0,151 & 0,278 & 0,229 & 0,265 & 0,251 & 0,218 & 0,259 & 0,351 & 0,353 & 0,330 & 0,340 & 0,338 \\
\hline $\mathrm{Al}$ & 1,826 & 1,880 & 2,426 & 2,402 & 2,434 & 2,394 & 2,377 & 2,357 & 2,028 & 2,066 & 1,996 & 2,046 & 2,047 \\
\hline $\mathrm{Fe}^{2}$ & 0,758 & 0,721 & 0,334 & 0,336 & 0,348 & 0,347 & 0,334 & 0,365 & 0,715 & 0,695 & 0,703 & 0,683 & 0,697 \\
\hline $\mathrm{Mn}$ & 0,003 & 0,003 & 0,002 & 0,007 & 0,000 & 0,006 & 0,001 & 0,002 & 0,005 & 0,000 & 0,004 & 0,002 & 0,003 \\
\hline $\mathrm{Mg}$ & 5,270 & 5,183 & 4,958 & 4,969 & 5,063 & 4,906 & 5,011 & 5,026 & 4,838 & 4,913 & 4,914 & 4,872 & 4,884 \\
\hline $\mathrm{Ca}$ & 0,004 & 0,003 & 0,005 & 0,002 & 0,005 & 0,002 & 0,001 & 0,005 & 0,003 & 0,009 & 0,001 & 0,000 & 0,002 \\
\hline $\mathrm{Ba}$ & 0,000 & 0,000 & 0,008 & 0,015 & 0,009 & 0,008 & 0,009 & 0,008 & 0,005 & 0,003 & 0,007 & 0,002 & 0,002 \\
\hline $\mathrm{Na}$ & 0,023 & 0,044 & 0,054 & 0,060 & 0,053 & 0,057 & 0,062 & 0,065 & 0,020 & 0,023 & 0,009 & 0,012 & 0,033 \\
\hline $\mathrm{K}$ & 1,981 & 1,955 & 1,948 & 1,957 & 1,954 & 1,911 & 1,868 & 1,966 & 1,946 & 1,961 & 1,941 & 1,933 & 1,957 \\
\hline $\mathrm{Cl}$ & 0,005 & 0,008 & 0,000 & 0,001 & 0,007 & 0,002 & 0,004 & 0,004 & 0,000 & 0,008 & 0,000 & 0,012 & 0,006 \\
\hline $\mathrm{F}$ & 0,218 & 0,225 & 0,178 & 0,181 & 0,110 & 0,141 & 0,086 & 0,340 & 0,192 & 0,364 & 0,088 & 0,343 & 0,238 \\
\hline $\mathrm{Cr}$ & 0,021 & 0,021 & n.a. & n.a. & n.a. & 0,236 & 0,235 & 0,254 & 0,050 & 0,044 & 0,037 & 0,040 & 0,047 \\
\hline Total & 16,205 & 16,162 & 15,939 & 15,959 & 15,943 & 15,910 & 15,868 & 16,223 & 15,968 & 16,198 & 15,873 & 16,114 & 16,054 \\
\hline $\mathrm{Mg} /(\mathrm{Mg}+\mathrm{Fe})$ & 0,874 & 0,878 & 0,937 & 0,937 & 0,936 & 0,934 & 0,937 & 0,932 & 0,871 & 0,876 & 0,875 & 0,877 & 0,875 \\
\hline
\end{tabular}




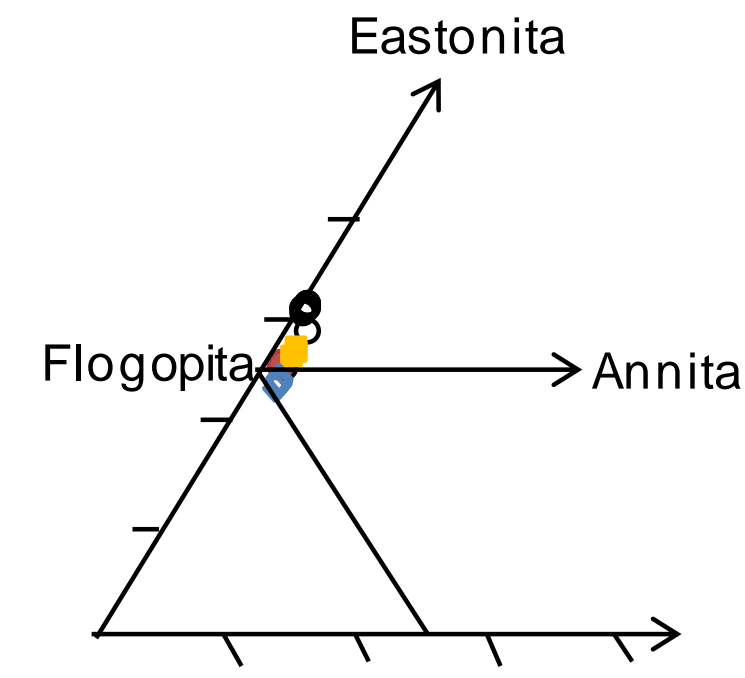

Tetra-ferri-flogopita

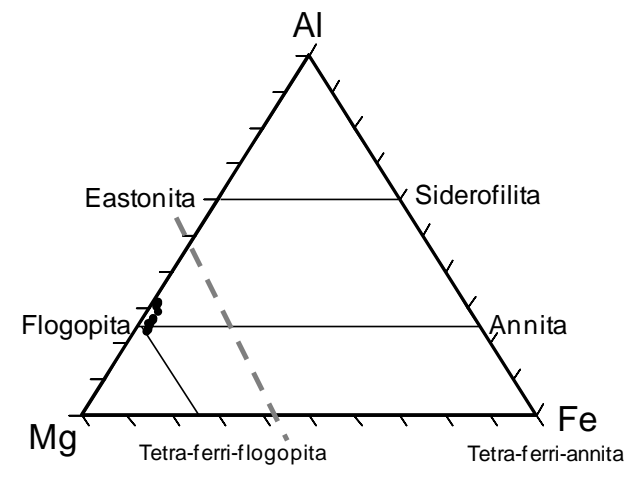

$\diamond$ Xenólito polimítico

Figura 28- Diagrama composicional de micas adaptado de Mitchell (1995). As micas dos xenólitos estudados concentram-se em torno do termo flogopita.

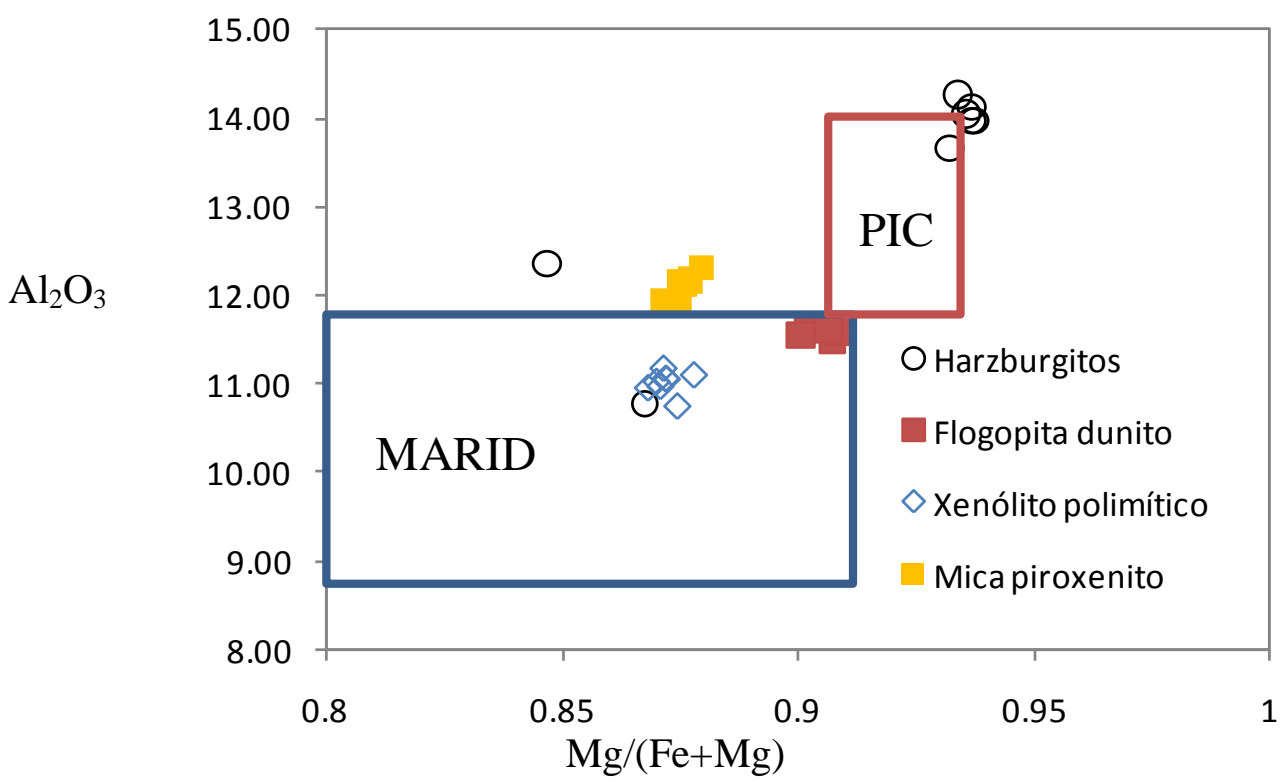

Figura 29- Composição química das flogopitas dos xenólitos estudados em diagrama de $\mathrm{Al}_{2} \mathrm{O}_{3}(\%$ wt. $)$ vs. $\mathrm{Mg} /(\mathrm{Mg}+\mathrm{Fe})$ mostrando os campos de xenólitos MARID e PIC, modificado de Grégoire et al. (2002). 


\subsection{Ilmenita}

A ilmenita não é um mineral freqüente nas amostras estudadas, e ocorre associada à flogopita em flogopita dunito e flogopita harzburgito, além de ocorrer em mica piroxenitos e no xenólito polimítico. As análises químicas deste mineral estão na Tabela 10.

No flogopita dunito da amostra In1/2, nos bolsões de flogopita $\mathrm{Mg} /(\mathrm{Mg}+\mathrm{Fe})$ é cerca de 0,41, $\mathrm{Fe}^{2} /\left(\mathrm{Fe}^{2}+\mathrm{Fe}^{3}\right) \quad 0,69, \mathrm{TiO}_{2} 47-48 \%$ e $\mathrm{Cr}_{2} \mathrm{O}_{3}$ 7,5\%. O alto valor de $\mathrm{Cr}$ se dá por causa da cromita abundante que ocorre na forma de grãos com contatos irregulares com grãos de ilmenita nesta amostra. Já no mica piroxenito da amostra In1/24b, bem como no xenólito polimítico da amostra In1/6, a razão $\mathrm{Mg} /(\mathrm{Mg}+\mathrm{Fe})$ varia entre $0,31-0,35, \mathrm{Fe}^{2} /\left(\mathrm{Fe}^{2}+\mathrm{Fe}^{3}\right) 0,70-0,81, \mathrm{TiO}_{2} 48-53 \%$ e $\mathrm{Cr}_{2} \mathrm{O}_{3} 1,5-2,1 \%$.

As ilmenitas estudadas têm composição química semelhante às descritas em kimberlitos da Austrália, Sibéria e América do Norte, como é mostrado na Figura 30, no diagrama de $\mathrm{TiO}_{2} \mathrm{X}$ MgO modificado de Wyatt et al. (2004). A composição é semelhante à dos macrocristais de ilmenitas do kimberlito hospedeiro, determinada por Silva (2008). Segundo a projeção no diagrama da Figura 31, as ilmenitas estudadas correspondem às encontradas nos xenólitos do tipo MARID, apesar de não terem sido identificados nestes xenólitos richterita e rutilo. 
Tabela 10- Análises químicas de ilmenita de xenólitos da intrusão Indaiá 1, obtidas por meio da microssonda eletrônica.

\begin{tabular}{|c|c|c|c|c|c|c|c|c|c|c|c|c|}
\hline & \multicolumn{2}{|c|}{ Flogopita dunito } & \multicolumn{7}{|c|}{ Xenólito polimítico } & \multicolumn{3}{|c|}{ Mica piroxenito } \\
\hline 2 & $2 / 1$ & $2 / 2$ & $6 / 1$ & $6 / 2$ & $6 / 3$ & $6 / 4$ & $6 / 5$ & $6 / 6$ & $6 / 7$ & $24 \mathrm{~b} / 1$ & $24 b / 2$ & $24 \mathrm{~b} / 3$ \\
\hline $\mathrm{SiO}_{3}^{2}$ & 0,02 & 0,00 & 0,03 & 0,02 & 0,01 & 0,03 & 0,00 & 0,03 & 0,02 & 0,04 & 0,01 & 0,00 \\
\hline $\mathrm{TiO}^{2}$ & 47,45 & 47,88 & 51,48 & 50,29 & 48,06 & 50,77 & 51,54 & 49,01 & 50,55 & 49,47 & 49,37 & 53,21 \\
\hline $\mathrm{Al} \mathrm{O}^{3}$ & 0,12 & 0,14 & 0,11 & 0,06 & 0,08 & 0,14 & 0,10 & 0,10 & 0,08 & 0,16 & 0,20 & 0,11 \\
\hline $\mathrm{Fe} 2 \mathrm{O}$ & 10,39 & 10,82 & 9,86 & 10,06 & 12,66 & 9,47 & 9,20 & 10,76 & 9,45 & 11,41 & 11,62 & 7,11 \\
\hline $\mathrm{FeO}$ & 21,16 & 21,15 & 26,51 & 28,14 & 26,17 & 28,53 & 28,14 & 25,67 & 28,05 & 26,26 & 26,40 & 28,46 \\
\hline $\mathrm{MnO}$ & 0,31 & 0,29 & 0,44 & 0,31 & 0,35 & 0,35 & 0,41 & 0,36 & 0,36 & 0,30 & 0,32 & 0,45 \\
\hline $\mathrm{MgO}_{3}$ & 11,87 & 12,12 & 10,87 & 9,40 & 9,37 & 9,43 & 9,97 & 10,13 & 9,57 & 10,07 & 9,92 & 10,58 \\
\hline $\mathrm{CaO}^{3}$ & 0,06 & 0,02 & 0,01 & 0,05 & 0,01 & 0,00 & 0,03 & 0,03 & 0,02 & 0,03 & 0,01 & 0,07 \\
\hline $\mathrm{CrO}$ & 7,52 & 7,58 & 1,65 & 1,57 & 1,53 & 1,52 & 1,51 & 1,57 & 1,58 & 2,12 & 1,98 & 2,09 \\
\hline $\mathrm{Nb} \mathrm{O}_{5}$ & 0,16 & 0,16 & 0,25 & 0,27 & 0,24 & 0,24 & 0,25 & 0,25 & 0,20 & 0,11 & 0,09 & 0,12 \\
\hline Total & 99,07 & 100,16 & 101,21 & 100,18 & 98,47 & 100,48 & 101,14 & 97,90 & 99,87 & 99,97 & 99,92 & 102,19 \\
\hline & \multicolumn{12}{|c|}{ Número de cátions com base em 3 átomos de oxigênio } \\
\hline $\mathrm{Si}$ & 0,001 & 0,000 & 0,001 & 0,001 & 0,000 & 0,001 & 0,000 & 0,001 & 0,000 & 0,001 & 0,000 & 0,000 \\
\hline $\mathrm{Ti}$ & 0,836 & 0,834 & 0,895 & 0,893 & 0,868 & 0,898 & 0,903 & 0,884 & 0,899 & 0,875 & 0,875 & 0,918 \\
\hline $\mathrm{Al}$ & 0,003 & 0,004 & 0,003 & 0,002 & 0,002 & 0,004 & 0,003 & 0,003 & 0,002 & 0,004 & 0,006 & 0,003 \\
\hline $\mathrm{Fe}^{3}$ & 0,183 & 0,188 & 0,172 & 0,179 & 0,229 & 0,168 & 0,161 & 0,194 & 0,168 & 0,202 & 0,206 & 0,123 \\
\hline $\mathrm{Fe}^{2}$ & 0,414 & 0,409 & 0,513 & 0,555 & 0,526 & 0,561 & 0,548 & 0,515 & 0,554 & 0,517 & 0,520 & 0,546 \\
\hline $\mathrm{Mn}$ & 0,006 & 0,006 & 0,009 & 0,006 & 0,007 & 0,007 & 0,008 & 0,007 & 0,007 & 0,006 & 0,006 & 0,009 \\
\hline $\mathrm{Mg}$ & 0,414 & 0,418 & 0,375 & 0,331 & 0,336 & 0,331 & 0,346 & 0,362 & 0,337 & 0,353 & 0,348 & 0,362 \\
\hline $\mathrm{Ca}$ & 0,001 & 0,001 & 0,000 & 0,001 & 0,000 & 0,000 & 0,001 & 0,001 & 0,001 & 0,001 & 0,000 & 0,002 \\
\hline $\mathrm{Cr}$ & 0,139 & 0,139 & 0,030 & 0,029 & 0,029 & 0,028 & 0,028 & 0,030 & 0,030 & 0,040 & 0,037 & 0,038 \\
\hline $\mathrm{Nb}$ & 0,002 & 0,002 & 0,003 & 0,003 & 0,003 & 0,003 & 0,003 & 0,003 & 0,002 & 0,001 & 0,001 & 0,001 \\
\hline Total & 2,000 & 2,000 & 2,000 & 2,000 & 2,000 & 2,000 & 2,000 & 2,000 & 2,000 & 2,000 & 2,000 & 2,000 \\
\hline $\mathrm{Mg} /(\mathrm{Mg}+$ FeTotal $)$ & 0,409 & 0,412 & 0,354 & 0,311 & 0,308 & 0,312 & 0,328 & 0,338 & 0,318 & 0,329 & 0,324 & 0,351 \\
\hline $\mathrm{Fe}^{2} /\left(\mathrm{Fe}^{2}+\mathrm{Fe}^{3}\right)$ & 0,694 & 0,685 & 0,749 & 0,757 & 0,697 & 0,770 & 0,773 & 0,726 & 0,767 & 0,719 & 0,716 & 0,817 \\
\hline
\end{tabular}




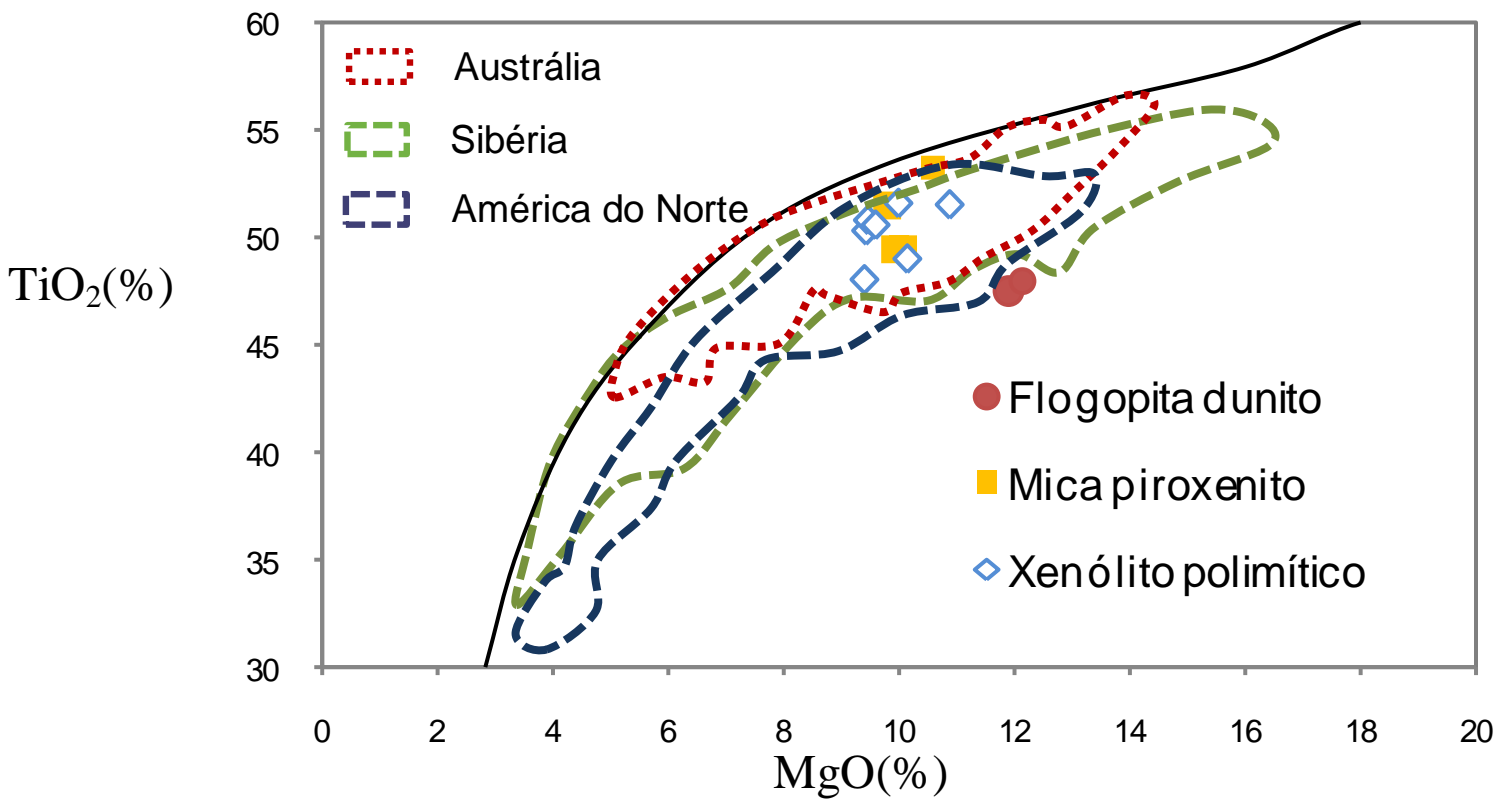

Figura 30- Variação química da ilmenita de xenólitos do Kimberlito Indaiá Wyatt et al. (2004).

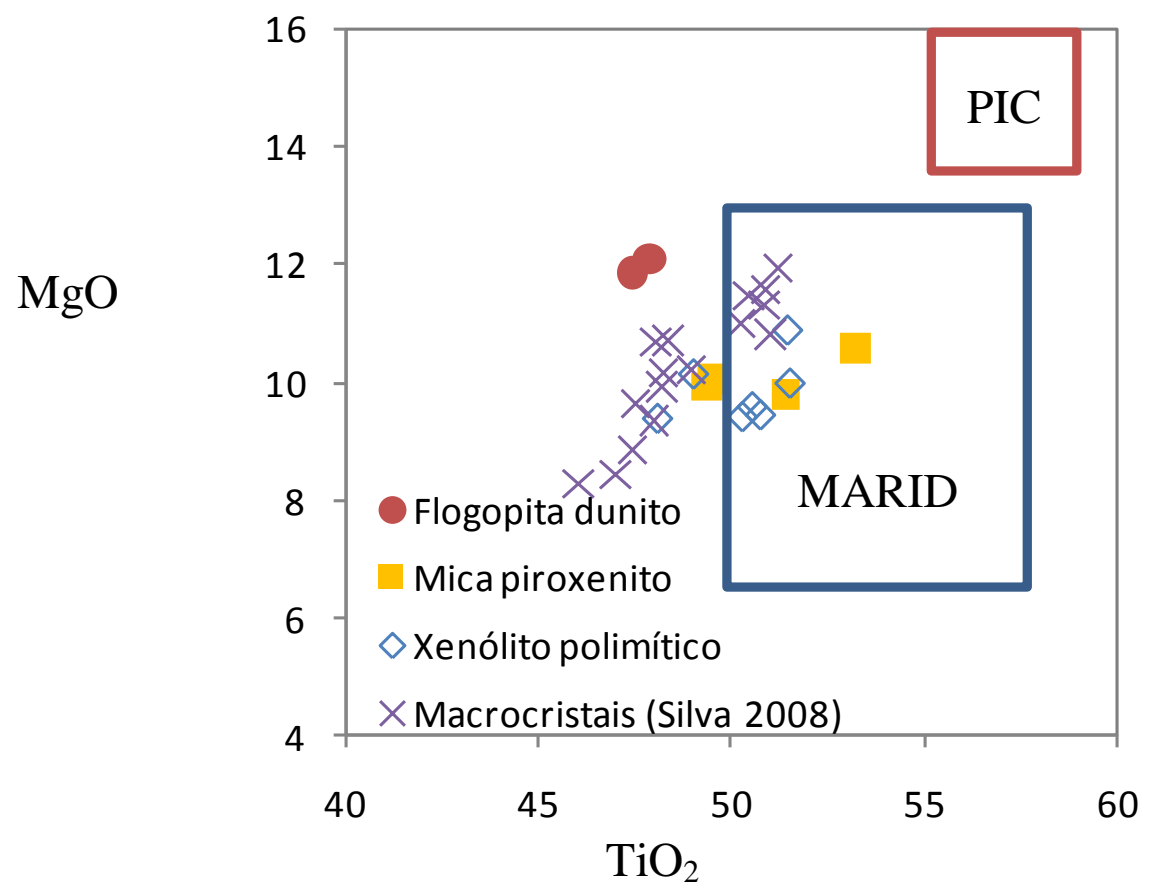

Figura 31- Variação química da ilmenita de xenólitos do Kimberlito Indaiá em diagrama de $\mathrm{MgO}(\% w t$. $)$ vs. $\mathrm{TiO}_{2}(\% w t$. $)$ mostrando os campos de xenólitos MARID e PIC, modificado de Grégoire et al.(2002). 


\subsection{Anfibólio}

Alguns cristais de anfibólio idiomórfico são encontrados em dunito com textura granoblástica da seção In1/24a. A Tabela 9 mostra os dados químicos obtidos. Os teores dos óxidos mais abundantes são: $\mathrm{TiO}_{2} 1,9-2,1 \% ; \mathrm{Al}_{2} \mathrm{O}_{3} 12 \% ; \mathrm{FeO} 2,5 \% ; \mathrm{MgO} 18 \% ; \mathrm{CaO} 11 \%, \mathrm{Na}_{2} \mathrm{O}$ 3,5\%; $\mathrm{K}_{2} \mathrm{O}$ 0,9-1,1\%; e $\mathrm{Cr}_{2} \mathrm{O}_{3}$ 2,41\%. Segundo a classificação de anfibólios de Hawtorne \& Oberti (2007) o mineral estudado é um anfibólio cálcico. A soma dos cátions Mg, Fe, Mn, Li, por fórmula no sítio B é maior ou igual a 0,5, a soma de Ca e Na no sítio B é maior ou igual a 1,5 e a quantidade de Na no sítio B é menor que 0,5. É classificado como pargasita, pois a quantidade de Ca no sítio B é superior a 1,5; a soma de Na e K no sítio A é maior que 0,5 e a quantidade de Ti é menor que 0,5; e o valor de Si está entre 5,5 a 6,5.

\subsection{Perovskita}

A perovskita é um mineral pouco frequente nas amostras estudadas; ocorre na matriz do Kimberlito Indaiá e nas amostras de flogopita dunito (In1/2), xenólito polimítico (In1/6) e mica peridotito (In1/24b e In1/31). Sua composição pode ser vista na Tabela 11.

\subsection{Silicato ou titanato não identificado}

$\mathrm{Na}$ amostra In/24b, no contato entre ilmenita e silicato (flogopita ou diopsídio), geralmente flogopita, ocorre um mineral com proporções de $\mathrm{SiO}_{2}$ e $\mathrm{TiO}_{2}$ parecidas, respectivamente de 22 a $25 \%$ e 24 a 32\%, com quantidades variadas de $\mathrm{MgO}, \mathrm{CaO}$, e FeO. Esta composição assemelha-se à do mineral denominado morimotoíta, do grupo da granada, com fórmula química $\mathrm{Ca}_{3} \mathrm{TiFe}^{2+} \mathrm{Si}_{3} \mathrm{O}_{12}$, descrito no trabalho de Henmi et al. (1995).

\subsection{Outras fases}

Outras fases presentes nos xenólitos são barita, pentlandita e galena. Em diversas amostras (In1/2, In1/6, In1/24b e In1/31) ocorre barita na forma venular, cujo teor obtido por EDS (semi-quantitativo) é indicado na Tabela 12. Os teores semi-quantitativos obtidos por EDS para pentlandita e galena, presentes na amostra In1/24b, também são apresentados na Tabela 13. 
Tabela 11- Análises químicas de anfibólio em xenólitos da intrusão Indaiá 1, obtidas por meio da microssonda eletrônica.

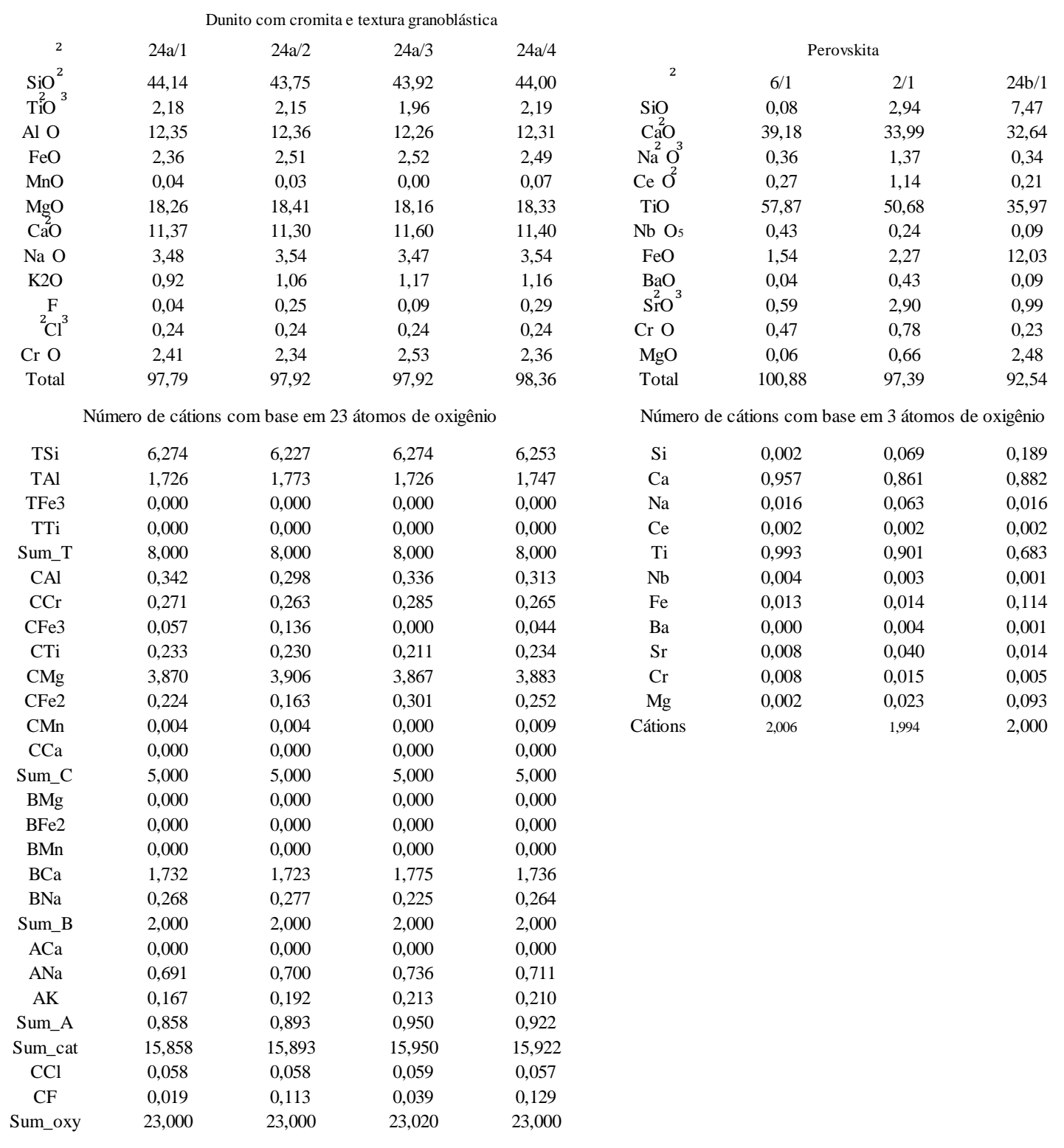


Tabela 12- Análises químicas de outras fases minerais não identificadas em xenólitos da intrusão Indaiá 1 , obtidas por meio da microssonda eletrônica.

Outras fases não identificadas

$\begin{array}{ccccc}2 & 24 \mathrm{~b} / 3 & 24 \mathrm{~b} / 2 & 24 \mathrm{~b} / 4 & 24 \mathrm{~b} / 5 \\ \mathrm{SiO}^{2} & 24,93 & 24,80 & 22,36 & 23,54 \\ \mathrm{TiO}^{2} & 31,68 & 24,05 & 28,06 & 25,84 \\ \mathrm{Al}^{2} \mathrm{O}^{3} & 0,39 & 0,06 & 0,07 & 0,11 \\ \mathrm{Fe} \mathrm{O} & 0,05 & 0,00 & 0,00 & 0,00 \\ \mathrm{FeO} & 26,44 & 13,64 & 13,87 & 13,14 \\ \mathrm{MnO} & 0,05 & 0,09 & 0,10 & 0,04 \\ \mathrm{MgO} & 12,69 & 2,66 & 3,07 & 2,87 \\ \mathrm{CaO} & 0,11 & 32,29 & 30,15 & 32,67 \\ \mathrm{Na} \mathrm{O}^{3} & 0,13 & 0,50 & 0,40 & 0,33 \\ \mathrm{Cr} \mathrm{O} & 0,28 & 0,24 & 0,37 & 0,28 \\ \mathrm{ZnO} & 2,62 & 0,02 & 0,00 & 0,00 \\ \mathrm{NiO} & --- & 0,03 & 0,00 & 0,00 \\ \mathrm{Total} & 99,37 & 98,37 & 98,46 & 98,83\end{array}$

Tabela 13- Análises semi-quantitativas obtidas por EDS de pentlandita, galena e barita.

\begin{tabular}{cc|cc|ccc}
\multicolumn{2}{c}{ Pentlandita } & \multicolumn{2}{c}{ Sulfeto de $\mathrm{Ni} \mathrm{e} \mathrm{Pb}$} & \multicolumn{2}{c}{ Barita } \\
\multicolumn{2}{c|}{ In1/24b } & \multicolumn{2}{c|}{ In1/24b } & & In1/6 & I1/24b \\
$\mathrm{O}$ & 28,24 & $\mathrm{O}$ & 16,00 & $\mathrm{O}$ & 18,93 & 18,34 \\
$\mathrm{Si}$ & 5,77 & $\mathrm{Mg}$ & 1,92 & $\mathrm{~S}$ & 12,14 & 18,22 \\
$\mathrm{~S}$ & 20,79 & $\mathrm{~S}$ & 23,30 & $\mathrm{Sr}$ & 0,53 & 0,00 \\
$\mathrm{Ca}$ & 7,49 & $\mathrm{Fe}$ & 3,41 & $\mathrm{Ba}$ & 68,39 & 63,44 \\
$\mathrm{Ti}$ & 1,35 & $\mathrm{Ni}$ & 33,20 & Total & 100,00 & 100,00 \\
$\mathrm{Fe}$ & 6,72 & $\mathrm{~Pb}$ & 22,18 & & & \\
$\mathrm{Ni}$ & 29,63 & Total & 100,01 & & &
\end{tabular}




\section{GEOTERMOBAROMETRIA}

A composição dos minerais formadores dos xenólitos é controlada por reações que podem ser sensíveis às condições de pressão e temperatura. $\mathrm{O}$ conhecimento das condições de equilíbrio químico dos minerais, baseado nos dados de química mineral gerados pela microssonda, torna possível a estimativa da pressão e temperatura de equilíbrio dos xenólitos. Por outro lado, deve se levar em conta que processos geológicos como fusão parcial e metassomatismo podem causar desequilíbrio químico no sistema, dificultando estas estimativas.

A determinação da temperatura de peridotitos do manto é baseada na troca Fe-Mg entre os minerais granada e clinopiroxênio, granada e olivina, ou espinélio e olivina. Já os geobarômetros, em sua maioria, são formulados com base no conteúdo de Al nos ortopiroxênios em equilíbrio com granada (Pearson et al. 2003). Entretanto, o geobarômetro de MacGregor (1974), baseado na solubilidade de $\mathrm{Al}_{2} \mathrm{O}_{3}$ no ortopiroxênio, tem sido usado, além de espécies com granada, também em espinélio lherzolitos (comunicação pessoal: Stephen E. Haggerty).

Em trabalho recente com espinélio lherzolitos sul-africanos, Grégoire et al. (2005) utilizaram os termômetros de Wells (1977) e Brey \& Köhler (1990), baseado em trocas de Fe-Mg entre ortopiroxênio e clinopiroxênio. No presente trabalho os mesmos termômetros foram utilizados em amostras com maior equilíbrio textural e sem influência do metassomatismo. As amostras selecionadas e os dados de temperatura obtidos pelo software PTEXL estão mostrados na Tabela 14.

O harzburgito com cromita com textura granoblástica da amostra In1/3 foi o exemplar que apresentou temperaturas mais elevadas $\left[901^{\circ} \mathrm{C}\right.$ no método de Wells (1977) e $908^{\circ} \mathrm{C}$ no método de Brey \& Khöler (1990)]. Já os harzburgitos com espinélio das amostras In1/9, In1/13a e o lherzolito com espinélio da amostra In1/14a apresentam temperaturas que variam de $656^{\circ} \mathrm{C}$ a $715^{\circ} \mathrm{C}$ seguindo a metodologia de Wells (1977). O método de Brey \& Khöler (1990) apresentou valores com temperaturas inferiores a $600^{\circ} \mathrm{C}$, muito baixas para rochas do manto superior.

Dados de pressão obtidos pelo barômetro de MacGregor (1974) apresentaram valores que se enquadram ou são próximos para rochas de fácies espinélio $(\sim 10-30$ kbar segundo Pearson et al., 2003), que são 36 kbar e 26 kbar, respectivamente, nas amostras In1/3 e In1/14a.

Para obter uma melhor avaliação das condições de $\mathrm{P}$ e $\mathrm{T}$ das rochas estudadas, foram comparados e projetados em diagrama alguns valores de corpos próximos à cidade de Coromandel, como Três Ranchos 4 (Alagoinha), Canastra 1 e Abel Régis, como mostra a Tabela 
14 e a Figura 32. O corpo Três Ranchos foi estudado inicialmente por Leonardos et al. (1993), que a partir de diferentes geotermômetros [Wells (1977); Finnerty \& Boyd (1986); MacGregor (1974); Brey et al .(1990)], determinaram uma sequência de pontos coerente com a geoterma de Pollack \& Chapman (1977) de $40 \mathrm{~W} / \mathrm{m}^{2}$, a partir de diopsídios e Cr-diopsídios de uma amostra de granada lherzolito. Costa (2008) também apresentou dados de geotermobarometria para este corpo. Em Costa (op.cit.) os xenólitos do Kimberlito Canastra 1 foram classificados petrograficamente e químicamente, além terem sido obtidos dados de geotermobarometria, por diversas metodologias. Para a projeção dos pontos de Costa (2008) no diagrama da Figura 32, somente foram utilizados os dados de granada lherzolitos, sendo selecionados os geotermobarômetros de Brey \& Khöler (1990), baseado nas trocas catiônicas entre orto e clinopiroxênios coexistentes como termômetro, e no conteúdo de Al no ortopiroxênio coexistente com granada como barômetro. Ainda utilizou-se de um dado da dissertação de mestrado de Thomaz (2009), de granada lherzolito obtido pelo geotermobarômetro de Brey et al. (2008).

Na Figura 32 é possível notar uma correlação positiva dos valores de pressão e temperatura entre os granada lherzolitos da região de Coromandel descritos na literatura e os valores do Kimberlito Indaiá. Os dados dos xenólitos do corpo Indaiá projetam-se fora do campo de estabilidade do diamante. 
Tabela 14- Dados de temperatura e pressão obtidos pelos termômetros Wells (1977) e Brey \& Khöler (1990), e barômetro de MacGregor (1974), de harzburgitos e lherzolitos do Kimberlito Indaiá, e comparação com dados geotermobarométricos de outros corpos próximos à Coromandel.

\begin{tabular}{|c|c|c|c|c|c|c|c|}
\hline Corpo & Amostra & Tipo litológico & $\begin{array}{c}\text { Wells } \\
(1977)\end{array}$ & $\begin{array}{c}\text { Brey \& } \\
\text { Khöeler (1990) }\end{array}$ & $\begin{array}{l}\text { Finnerty \& } \\
\text { Boyd (1986) }\end{array}$ & $\begin{array}{c}\text { MacGregor } \\
(1974)\end{array}$ & $\begin{array}{l}\text { Brey et al. } \\
\quad(2008)\end{array}$ \\
\hline \multirow{4}{*}{ Indaiá } & In1/3 & $\begin{array}{l}\text { Harzburgito com } \\
\text { cromita } \\
\end{array}$ & $901^{\circ} \mathrm{C}$ & $908^{\circ} \mathrm{C}$ & ---------- & 36Kbar & --------- \\
\hline & In1/9 & $\begin{array}{c}\text { Harzburgito com } \\
\text { espinélio }\end{array}$ & $715^{\circ} \mathrm{C}$ & $615^{\circ} \mathrm{C}$ & ------------ & --------- & --------- \\
\hline & In1/13a & $\begin{array}{c}\text { Harzburgito com } \\
\text { espinélio } \\
\end{array}$ & $724^{\circ} \mathrm{C}$ & $650^{\circ} \mathrm{C}$ & ----------- & ---------- & ---------- \\
\hline & In1/14a & $\begin{array}{c}\text { Lherzolito com } \\
\text { espinélio }\end{array}$ & $656^{\circ} \mathrm{C}$ & $529^{\circ} \mathrm{C}$ & ------------ & 26Kbar & ---------- \\
\hline \multirow{2}{*}{$\begin{array}{l}\text { Três Ranchos } 4 \\
\text { (Costa, 2008) }\end{array}$} & JBTR1 & Granada lherzolito & $974^{\circ} \mathrm{C}$ & $1065^{\circ} \mathrm{C} / 50 \mathrm{Kbar}$ & ------------ & $51 \mathrm{Kbar}$ & 43Kbar \\
\hline & JBTR3 & Granada lherzolito & $1037^{\circ} \mathrm{C}$ & $1139^{\circ} \mathrm{C} / 40 \mathrm{Kbar}$ & ----------- & $45 \mathrm{Kbar}$ & $36 \mathrm{Kbar}$ \\
\hline \multirow{6}{*}{$\begin{array}{c}\text { Três Ranchos } 4 \\
\text { (Leonardos et al. 1993) }\end{array}$} & & \multirow{6}{*}{ Granada lherzolito } & --------- & $1273^{\circ} \mathrm{C} / 78 \mathrm{Kbar}$ & ------------- & ----------- & ---------- \\
\hline & & & --------- & ----------- & $1192^{\circ} \mathrm{C}$ & 72Kbar & ---------- \\
\hline & & & $1120^{\circ} \mathrm{C}$ & ----------- & ----------- & 66Kbar & --------- \\
\hline & & & --------- & $1063^{\circ} \mathrm{C} / 57 \mathrm{Kbar}$ & ----------- & ----------- & --------- \\
\hline & & & --------- & ----------- & $1021^{\circ} \mathrm{C}$ & 59Kbar & ---------- \\
\hline & & & $977^{\circ} \mathrm{C}$ & & & $55 \mathrm{Kbar}$ & ---------- \\
\hline \multirow{7}{*}{$\begin{array}{c}\text { Canastra } 1 \\
(\text { Costa, 2008) }\end{array}$} & Can88 & Granada lherzolito & -------- & $1282^{\circ} \mathrm{C} / 66 \mathrm{Kbar}$ & -------- & $57 \mathrm{Kbar}$ & $60 \mathrm{Kbar}$ \\
\hline & Can89 & Granada lherzolito & -------- & $1261^{\circ} \mathrm{C} / 62 \mathrm{Kbar}$ & -------- & $58 \mathrm{Kbar}$ & $57 \mathrm{Kbar}$ \\
\hline & Can96 & Granada lherzolito & -------- & $1255^{\circ} \mathrm{C} / 59 \mathrm{Kbar}$ & -------- & $58 \mathrm{Kbar}$ & ---------- \\
\hline & Can97 & Granada lherzolito & $1212^{\circ} \mathrm{C}$ & $1243^{\circ} \mathrm{C} / 58 \mathrm{Kbar}$ & -------- & $59 \mathrm{Kbar}$ & $54 \mathrm{Kbar}$ \\
\hline & Can100 & Granada lherzolito & $1233^{\circ} \mathrm{C}$ & $1278^{\circ} \mathrm{C} / 57 \mathrm{Kbar}$ & -------- & $58 \mathrm{Kbar}$ & $53 \mathrm{Kbar}$ \\
\hline & Can101 & Granada lherzolito & -------- & $1253^{\circ} \mathrm{C} / 53 \mathrm{Kbar}$ & -------- & $58 \mathrm{Kbar}$ & $50 \mathrm{Kbar}$ \\
\hline & Can104 & Granada lherzolito & -------- & $1265^{\circ} \mathrm{C} / 54 \mathrm{Kbar}$ & -------- & $58 \mathrm{Kbar}$ & $51 \mathrm{Kbar}$ \\
\hline $\begin{array}{c}\text { Abel Régis } \\
\text { (Thomaz, 2009) }\end{array}$ & $104,15 a$ & Granada lherzolito & $1053^{\circ} \mathrm{C}$ & ---------------- & -------- & ---------- & $1189^{\circ} \mathrm{C} / 40 \mathrm{Kbar}$ \\
\hline
\end{tabular}




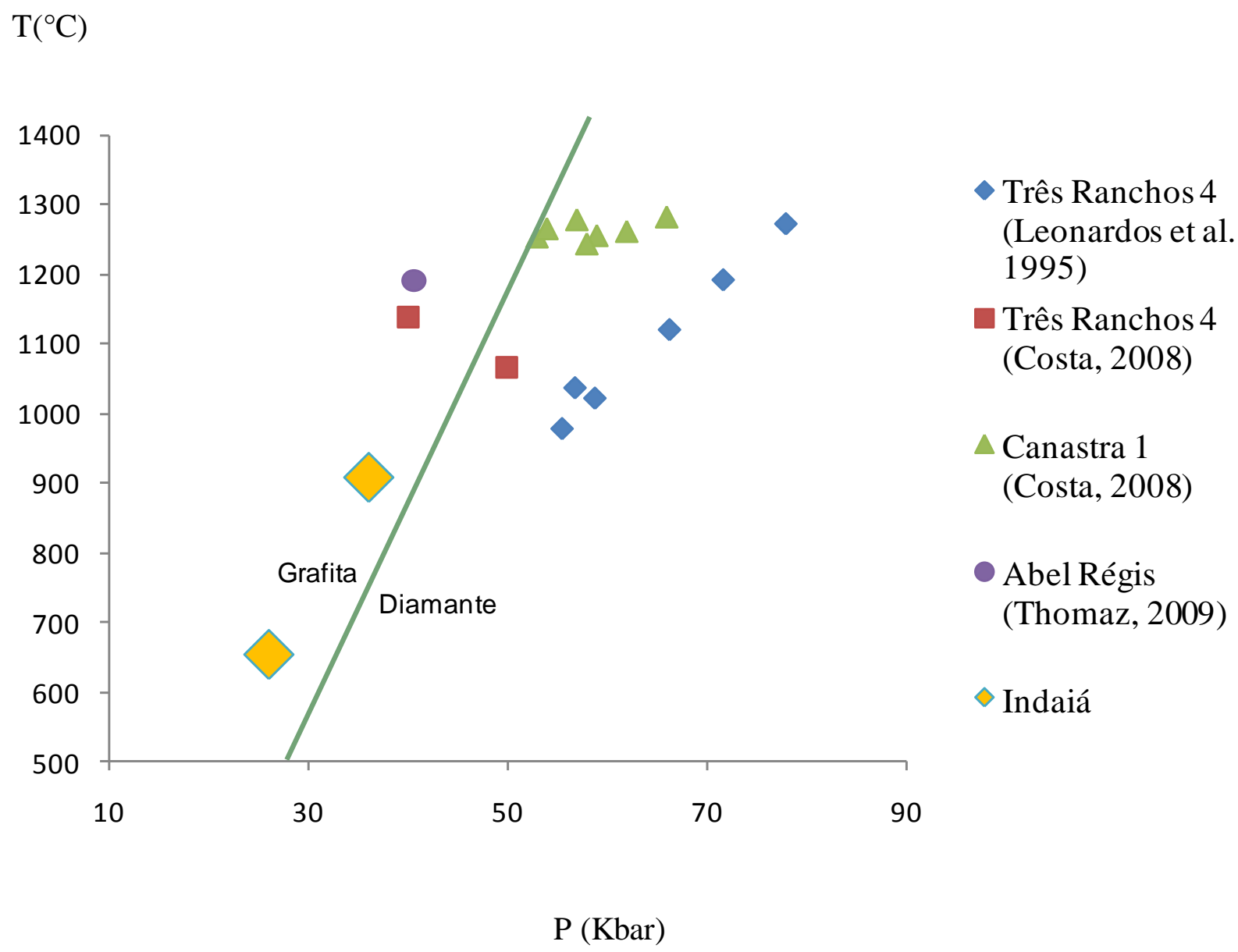

Figura 32 - Dados de pressão e temperatura de granada lherzolitos da região de Coromandel descritos na literatura. O diagrama delimita também um campo de tendência para a geoterma local e também um possível campo de estabilidade dos xenólitos do Kimberlito Indaiá, além de dois dados com estimativas de pressão para este corpo. 


\section{DISCUSSÃO GERAL}

A tipologia de xenólitos geralmente está ligada ao ambiente tectônico e ao tipo de rocha eruptiva vulcânica em que eles são encontrados. Websteritos, wehrlitos e piroxenitos são mais comuns em álcali basaltos que em kimberlitos; por outro lado, suítes empobrecidas como harzburgitos e dunitos são mais abundantes em kimberlitos. Xenólitos que sofreram processos de enriquecimento por metassomatismo são comuns em ambos os tipos de eruptivas, assim como os lherzolitos (Haggerty 1995). Estes últimos, de baixa pressão (com espinélio) ou alta pressão (com granada) são os tipos mais férteis, ou seja são capazes de produzir magmas basálticos com alto $\mathrm{Ca}, \mathrm{Al}, \mathrm{Fe}$ e $\mathrm{Si}$, sendo que os lherzolitos considerados primitivos são aqueles que contêm pelo menos 15\% de clinopiroxênio (Le Roux et al. 2007; Sun \& McDonough 1989; McDonough \& Sun 1995)

Segundo Carlson et al. (2007) os peridotitos presentes nas rochas vulcânicas alcalinas da região do Alto Paranaíba são geralmente empobrecidos em $\mathrm{Ca}, \mathrm{Al}$ e $\mathrm{Re}$, o que indica que são resíduos de extração de magmas por fusão parcial. De acordo com esses autores, idades modelo de empobrecimento de Re de 2,4 Ga para estes peridotitos indicam que esta área repousa sobre um manto litosférico empobrecido de idade neoproterozóica a eoarqueana do Cráton do São Francisco.

No corpo Indaiá a maioria dos xenólitos corresponde a harzburgitos, e são raros os piroxenitos, o que mostra que este corpo de fato acompanha uma moda de litotipos xenolíticos semelhante à descrita na literatura para kimberlitos. Do mesmo modo, é característico o empobrecimento em $\mathrm{Ca}, \mathrm{Al}, \mathrm{Fe}$, que pode ser verificado pela óbvia escassez de clinopiroxênio nos harzburgitos, e pelo fato de este mineral já ser empobrecido em $\mathrm{Al}$ e $\mathrm{Fe}$ quando presente nestas rochas. A diversidade de texturas nos xenólitos reflete uma amostragem pelo kimberlito de zonas que sofreram graus diferentes de cisalhamento, além das modificações provocadas pela passagem de fluidos metassomáticos, que afetaram as características originais da rocha.

A ausência de granada nos xenólitos do corpo Indaiá implica em uma amostragem de níveis mais rasos do manto, como indica a diagrama de Pearson et al. (2003) da Figura 33, sendo assim a projeção das pressões no campo da granada sugere que o barômetro de MacGregor (1974) não seja preciso para os xenólitos estudados. 
Grégoire et al. (2002) fizeram um estudo em xenólitos com as associações PIC e MARID de kimberlitos da área de Kimberley, na África do Sul, e sugeriram que estes xenólitos seriam segregações no manto de fundidos altamente alcalinos. De acordo com esses autores, as espécies PIC têm relação genética íntima com os kimberlitos do tipo I e os MARID têm origem ligada aos kimberlitos do tipo II (orangeítos, Mitchell 1995). Segundo Grégoire et al. (op.cit.) os dois tipos de fundidos parentais percolaram, e metassomatizaram, o manto superior sob a área de Kimberley. Ainda são poucos os estudos sobre xenólitos das suítes MARID e PIC na região do Alto Paranaíba para definir uma predominância entre estas duas espécies litológicas e a correlação entre estes tipos de xenólitos e os kimberlitos da região em termos de mineralogia e química. Porém, devido às similaridades de contexto geológico, características mineralógicas e químicas entre os kimberlitos da área de Kimberley e da Província Kimberlítica do Alto Paranaíba, é possível que a correlação entre os xenólitos MARID ou PIC e os kimberlitos seja semelhante à estudada na África do Sul por Grégoire et al. (op.cit.).

A intrusão Indaiá está localizada a cerca de $1 \mathrm{~km}$ da intrusão kimberlítica denominada Limeira (Almeida 2009), que apresenta aspectos muito parecidos em relação às características petrográficas do kimberlito e dos xenólitos, como mostra a Tabela 15. A proximidade entre os corpos e as características semelhantes entre eles sugere que existe uma relação cogenética, ou mesmo que estes dois pipes teriam sido gerados no mesmo pulso, mas divididos em dois diatremas distintos.

A ausência de granada tanto nos xenólitos como na matriz do Kimberlito Indaiá dificulta uma aferição precisa sobre o potencial diamantífero do corpo (Nixon, 1995). Pelos dados de geotermobarometria aqui apresentados, com temperaturas e pressão bem abaixo dos corpos mineralizados estudados, o Kimberlito Indaiá não pode ser considerado como de alto potencial de mineralização. 


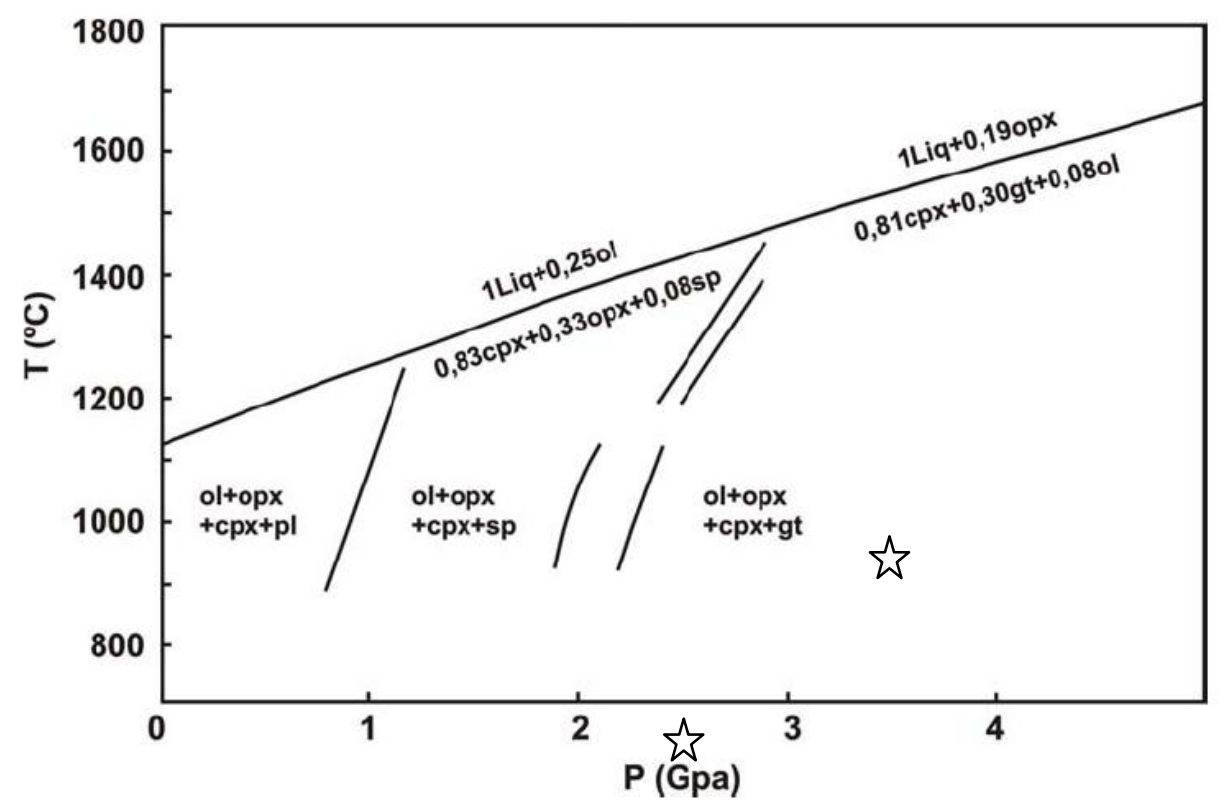

Figura 33 - Diagrama de campo de estabilidade Temperatura vs. Pressão das fases aluminosas plagioclásio, espinélio e granada, extraído de Pearson et al. (2003), mostrando a temperatura e pressão de equilíbrio de dois xenólitos do Kimberlito Indaiá.

Tabela 15- Comparação de xenólitos de dois corpos da Província Kimberlítica de Coromandel (Indaiá e Limeira) e de corpos conhecidos na África do Sul e Tanzânia.

\begin{tabular}{|c|c|c|c|c|}
\hline Intrusão & $\begin{array}{c}\text { Indaiá } \\
\text { (este trabalho) }\end{array}$ & $\begin{array}{c}\text { Limeira } \\
\text { (Almeida 2008) }\end{array}$ & $\begin{array}{l}\text { Premier, África do Sul } \\
\text { (Grégoire 2005) }\end{array}$ & $\begin{array}{l}\text { Lashaine e Olmani, } \\
\text { Tanzania (Rudnick, } \\
\text { 1991) }\end{array}$ \\
\hline $\begin{array}{l}\text { Minerais } \\
\text { principais }\end{array}$ & $\begin{array}{l}\text { Olivina, enstatita, } \\
\text { diopsídio, augita, } \\
\text { espinélio, flogopita e } \\
\text { ilmenita. }\end{array}$ & $\begin{array}{l}\text { Olivina, enstatita, diopsídio, } \\
\text { augita, espinélio, flogopita e } \\
\text { ilmenita. }\end{array}$ & $\begin{array}{l}\text { Olivina, enstatita, } \\
\text { diopsídio e espinélio. }\end{array}$ & $\begin{array}{l}\text { Olivina, enstatita, } \\
\text { clinopiroxênio, granada, } \\
\text { espinélio e flogopita }\end{array}$ \\
\hline $\begin{array}{l}\text { Minerais } \\
\text { acessórios }\end{array}$ & $\begin{array}{l}\text { Cromita, magnetita, } \\
\text { anfibólio, perovskita, } \\
\text { zircão, badeleíta e } \\
\text { galena. }\end{array}$ & $\begin{array}{l}\text { Cromita, priderita, } \\
\text { mathiasita, calcita, } \\
\text { perovskita e rutilo. }\end{array}$ & Flogopita e anfibólio. & Apatita e monazita. \\
\hline $\begin{array}{c}\text { Texturas } \\
\text { predominantes }\end{array}$ & $\begin{array}{c}\text { Grossa, porfiroclástica e } \\
\text { granoblástica (Harte } \\
\text { 1977). } \\
\end{array}$ & $\begin{array}{l}\text { Protogranular (Mercier \& } \\
\text { Nicolas 1975), transicional. }\end{array}$ & $\begin{array}{c}\text { Protogranular (Mercier \& } \\
\text { Nicolas 1975) }\end{array}$ & $\begin{array}{l}\text { Grossa e granoblastica } \\
\text { (Haste, 1977). }\end{array}$ \\
\hline Olivina & $\mathrm{Fo}=83-93$ & $\mathrm{Fo}=88-92$ & $\mathrm{Fo}=90-92$ & $\mathrm{Fo}=87-94$ \\
\hline Ortopiroxênio & $\begin{array}{c}\mathrm{Wo}=0,1-3 ; \mathrm{En}=84-93 ; \\
\text { Fs } 7-14\end{array}$ & $\begin{array}{c}\mathrm{Wo}=0,5-1,9 ; \mathrm{En}=88-91 ; \\
\mathrm{Fs}=8-11\end{array}$ & $\begin{array}{c}\mathrm{Wo}_{0}=0,4-2,1 ; \mathrm{En}=89-92 ; \\
\text { Fs }=7-9\end{array}$ & $\begin{array}{c}\mathrm{Wo}=0,1-0,2 ; \mathrm{En}=89-94 ; \\
\mathrm{Fs}=6-11\end{array}$ \\
\hline Clinopiroxênio & $\begin{array}{c}\mathrm{Wo}=41-51 ; \mathrm{En}=45-52 ; \\
\mathrm{Fs}=0,2-8\end{array}$ & $\begin{array}{c}\mathrm{Wo}=42-50 ; \mathrm{En}=44-52 ; \\
\mathrm{Fs}=3-11\end{array}$ & $\begin{array}{c}\text { Wo=46-49; En=47-51; } \\
F_{s}=2,3-3,5\end{array}$ & $\begin{array}{c}\mathrm{Wo}=41-46 ; \mathrm{En}=46-56 ; \\
\mathrm{Fs}=3-7\end{array}$ \\
\hline Espinélio & $\begin{array}{c}\text { \#Mg 0,10-0,75; \#Cr } \\
0,16-0,98\end{array}$ & 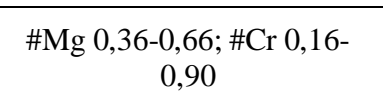 & $\begin{array}{c}\text { \#Mg 0,67-0,72; \#Cr 0,32- } \\
0,45\end{array}$ & \#Mg 44-81; \#Cr 20-85 \\
\hline Flogopita & \#Mg 86-94 & $\# \mathrm{Mg} 80-90$ & 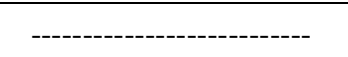 & $\# \mathrm{Mg} 88-95$ \\
\hline
\end{tabular}




\section{CONCLUSÕES}

1) Apesar da grande variedade de xenólitos mantélicos no Kimberlito Indaiá, predominam espécies com composição harzburgítica ou próximas a esta composição.

2) O metassomatismo mantélico é evidenciado por bolsões ricos em flogopita, minerais opacos e clinopiroxênios, além dos xenólitos polimíticos e dos mica piroxenitos presentes.

3) A variedade de textural das amostras é de grossa (coarse ou protogranular) a granoblástica, e evidencia processos de fusão e recristalização.

4) Os nódulos mantélicos correspondem à fácies espinélio, com temperaturas que variam de 655 a $908^{\circ} \mathrm{C}$, como indicam os dados de geotermobarometria. A ausência de granada e a comparação das condições de pressão e temperatura com outros kimberlitos mineralizados da região indicam que há poucas chances do Kimberlito Indaiá ser mineralizado.

5) De um modo geral, a composição química das fases constituintes dos xenólitos presentes no Kimberlito Indaiá é semelhante aos seus correspondentes encontrados no Kimberlito Limeira, situado apenas $1 \mathrm{~km}$ a norte.

6) Na olivina, os valores maiores de \# Mg e $\mathrm{NiO}$ são encontrados em harzburgitos e dunitos. Lherzolitos apresentam quantidade semelhante de $\mathrm{NiO}$, mas menor \#Mg. A olivina de xenólitos polimíticos apresenta $\mathrm{NiO}$ e \#Mg menores.

7) $\mathrm{O}$ clinopiroxênio dos lherzolitos contém quantidades maiores de $\mathrm{Al}_{2} \mathrm{O}_{3}$ e Ca em relação aos harzburgitos e dunitos, o que confirma o seu caráter relativamente fértil.

8) Nos lherzolitos e harzburgitos com clinopiroxênio o espinélio tem a razão \#Cr baixa. Nos nódulos mais refratários (dunitos e harzburgitos com \#Mg alto) o espinélio apresenta \#Cr mais altos. Já no xenólito polimítico os \#Mg são menores e \#Cr variado.

9) As composições químicas dos minerais indicam que os harzburgitos e dunitos sofreram processo de fusão parcial, concentrando elementos com o $\mathrm{Mg}, \mathrm{Ni}$ e $\mathrm{Cr}$. O metassomatismo é evidenciado principalmente pela presença de micas e pelos valores de \#Mg mais baixos nas fases silicáticas presentes em mica piroxenitos, xenólito polimítico e flogopita dunitos. 


\section{AGRADECIMENTOS}

Agradeço a todas as pessoas que contribuíram de forma direta ou indireta para que esta dissertação fosse realizada.

Ao meu orientador Valdecir de Assis Janasi, que me estimulou, primeiramente através de suas intrigantes aulas, a "mergulhar" no fascinante mundo da Petrologia além do constante apoio e das proveitosas discussões e "devaneios".

Ao meu "co-orientador" Darcy Pedro Svisero que me "acolheu" durante praticamente todo o tempo, e me incentivou persistentemente em fazer os trabalhos cuidadosamente e com qualidade, além de inúmeros outros conselhos, tanto para esta dissertação quanto para a vida.

À minha família que me ensinou a seguir o caminho do bem, que julgo hoje ser o mais apropriado, além de ter dado grande apoio nas horas difíceis. Aos meus pais Elizabeth e Paulo, por não pouparem esforços por fazerem o melhor que podiam por mim. Às minhas irmãs Karina e Graziella por sempre estarem dispostas a uma boa conversa. À minha querida avó pela torcida.

Aos meus grandes amigos que tanto me fizeram rir e chorar de rir. Ao meu grande amigo Elton John que mesmo morando na "casa do chapéu" não deixa de ser uma pessoa de amizade única. À minha grande amiga Rachel com quem aprendi muitas coisas, e sobre a possibilidade de um dia eu me tornar professor (quem sabe?). Ao Lulla Molusko e Ximpolino que vêm sendo ao longo destes últimos anos parceiros de baladas. Aos meus amigos do Mestrado, Alice Westin, Asnah, Pânico, Popó, Entaladah, Rejeitto, Meninão, Furadeira, Lua, Bisteca, e muitos outros. Aos meus amigos da sala mais barulhenta do Bloco B, a sala B-9, composta por mim (GG), Pedro (Porra), Leonardo Frederico (Harry Potter), Roberta (Pisa) e Diana (Lady Godiva).

Aos meus amigos teatrais do teatro, que me deram espírito novo na reta final. Aos amigos do Espaço Macunaíma: Artur, André, Tainá, Adriana, Patrícia, Mireille, Rodrigo, Diogo e demais. Aos amigos da OPSIS: Cadu, Luis, Raquel, Thaís, Joici e Edna.

A todos os funcionários do IGc-USP que colaboraram de alguma forma com o trabalho, em especial a, Sandra Andrade, Marcos Mansueto, Isaac Jamil Sayeg e Jaime de Souza Marcos.

Agradeço ao técnico de mineração Luiz Alberto, essencial na etapa de campo.

Um agradecimento especial pra Deus que me permitiu ter alegria sempre. 


\section{REFERÊNCIAS BIBLIOGRÁFICAS}

Almeida F.F.M. de 1958. Geologia e petrologia do Arquipélago de Fernando de Noronha. Departamento Nacional da Produção Mineral (DNPM), Rio de Janeiro (RJ), Monografia 13, $181 \mathrm{p}$.

Almeida F.F.M. de 1961. Geologia e petrologia da ilha de Trindade. Departamento Nacional da Produção Mineral (DNPM), Rio de Janeiro (RJ), Monografia 18, 197 p.

Almeida V.V. 2009. Mineralogia e petrologia de xenólitos mantélicos das regiões de Ubatuba (SP) e Monte Carmelo (MG): evidências de fusão parcial e metassomatismo no manto superior do sudeste do Brasil. Dissertação de Mestrado Instituto de Geociências, Universidade de São Paulo, 153p.

Araujo A.L.N., Carlson R.W., Gaspar J.C. and Bizzi L.A., 2001. Petrology of kamafugites and kimberlites from the Alto Paranaíba Alkaline Province, Minas Gerais, Brazil. Contributions to Mineralogy and Petrology, 142(2): 163-177.

Barbosa O., Braun O.P.G., Dyer R.C., Cunha C.A.B.R. 1970. Geologia da região do Triângulo Mineiro. Rio de Janeiro, DNPM/DFPM, Boletim 136, 140p.

Bastin G.F., van Loo F.J.J., Heijiligers H.J.M. 1984. Evaluation and use of Gaussian curves in quantitative electron probe microanalisys: a new optimization. X-ray Spectrometry, 13: 91-97.

Boullier A.M., Nicolas A. 1975. Classification of textures and fabrics of peridotites xenoliths from South African Kimberlites. In: Ahrens L.H., Dawson J.B., Duncan A.R., Erlank A.J. (eds.) Physics and Chemistry of the Earth, Oxford, Pergamon, 9: 467-475.

Brey G.P. \& Köhler T. 1990. Geothermobarometry in four-phase lherzolites II. New thermobarometers, and practical assessment of existing thermobarometers. Journal of Petrology, 31: 1353-1378.

Brey G.P., Köhler T., Nickel K.G.. 1990. Geothermobarometry in four phase lherzolites I. Experimental results from 10 to $60 \mathrm{~kb}$. Journal of Petrology, 31:1313-1352.

Brey G. P., Bulatov V. K., Girnis A. V. 2008. Geobarometry for peridotites: experiments in simple and natural systems for 6 to $10 \mathrm{GPa}$. Journal of Petrology, 49 (1):3-24.

Carlson R.W., Araújo, A.L.N. Junqueira-Brod T.C., Gaspar J.C., Brod J.A., Petrinovic I.A., Hollanda M.H.B.M., Pimentel M.M., Sichel S. 2007. Chemical and isotopic relationships between peridotite xenoliths and mafic-ultrapotassic rocks from Southern Brazil. Chemical Geology, 242: 415-434.

Carswell D.A. 1975. Primary and secondary phlogopites and clinopyroxenes in garnet lherzolite xenoliths. In: Ahrens L.H., Dawson J.B., Duncan A.R., Erlank A.J. (eds.) Physics and Chemistry of the Earth, Oxford, Pergamon, 9: 467-475. 
Costa G.V. 2008. Química mineral e geotermobarometria de xenólitos mantélicos do kimberlito Canastra-01. Dissertação de Mestrado, Instituto de Geociências, Universidade de Brasília, $137 \mathrm{p}$.

Costa V.S. 2010. Petrologia dos xenólitos mantélicos da Província Kimberlítica de Juína, MT. Exame de Qualificação de Doutorado apresentado ao Instituto de Geociências, Universidade de São Paulo, 79p.

Cox K.G., Gurney J.J., Harte, B. 1973. Xenoliths from the Matsoku pipe. In: Nixon, P.H.(ed). Lesotho Kimberlites. Maseru. Lesotho National Development Corporation, p.76-98.

Dawson J. B. 1987. The MARID suite of xenoliths in kimberlite: relationship to veined and metasomatised peridotite xenoliths. In: P. H. Nixon (ed.) Mantle xenoliths. John Wiley \& Sons Ltd., p. 465-473.

Dawson J.B. 1980. Kimberlite and their xenoliths. Spring -Verlag, New York, 252p.

Dawson J.B. \& Smith J.V. 1975. Chromite-silicate intergrowths in upper-mantle peridotites. Physics and Chemistry of the Earth, 9: 339-350.

Eggins S.M., Rudnick R.L., McDonough W.F. 1998. The composition of peridotites and their minerals: a laser ablation ICP-MS study. Earth and Planetary Science Letters 154: 53-71.

Finnerty A.A. \& Boyd F.R. 1978. Pressure dependent solubility of calcium in forsterite coexisting with diopside and enstatite. Carnegie Institution of Washington, Yearbook 77: 713717.

Gibson S.A., Thompson R.N., Leonardos O.H., Dickin A.P. and Mitchell J.G., 1995. The Late Cretaceous impact of the Trindade mantle plume: Evidence from large-volume, mafic, potassic magmatism in SE Brazil. J. Petrology, 36(1): 189-229.

Gomes C.B. \& Girardi V.A.V. 1973. Princípios e aplicações da microssonda eletrônica. Ciência e Cultura (SBPC), 25(8): 711-722.

Grégoire M., Bell D.R., Le Roex A.P. 2002. Trace element geochemistry of phlogopite-rich mafic mantle xenoliths: their classification and their relationship to phlogopite-bearing peridotites and kimberlites revisited. Contributions to Mineralogy and Petrology, 142: 603625 .

Grégoire M., Tinguely C., Bell D.R., le Roex A.P. 2005. Spinel lherzolite xenoliths from the Premier kimberlite (Kaapvaal craton, South Africa): Nature and evolution of the shallow upper mantle beneath the Bushveld complex. Lithos, 84:185-205.

Griffin W.L., Ryan C.G., Gurney J.J., Sobolev N.V., Win T.T. 1991. Chromite macrocrysts in kimberlites and lamproites: geochemistry and origin. In: Proceedings of the $5^{\text {th }}$ International Kimberlite Conference. v.1, p.366-377. 
Haggerty S.E., Smyth J.R., Erlank A.J., Rickard R.S., Danchin R.V. 1983. Lindsleyite (Ba) and mathiasite $(\mathrm{K})$ : two new chromium-titanates in the crichtonite series from the upper mantle. American Mineralogist, 68:494-505.

Haggerty S. E. 1995. Upper mantle mineralogy. Journal of Geodynamics, 20: 331-364.

Harte B. 1977. Rock nomenclature with particular relation to deformation and recrystallization textures in olivine-bearing xenoliths. Journal of Geology, 85: 279-288.

Hawthorne F.C. \& Oberti, R. 2007. Classification of Amphiboles. Reviews in Mineralogy \& Geochemistry, 67: 55-88.

Helmbold, R. 1968. Ultrabasic nodules in analcite basanite of Guaratibe, State of Guanabara, Brazil. Anais da Academia Brasileira de Ciências, 40: 141-147.

Henmi C., Kusachi I., Henmi K. 1995. Morimotoite, $\mathrm{Ca}_{3} \mathrm{TiFe}^{2+} \mathrm{Si}_{3} \mathrm{O}_{12}$, a new titanian garnet from Fuka, Okayyama Prefecture, Japan. Mineralogical Magazine, 59:115-120.

Janasi V.A., Almeida V.V., Andrade S., Svisero D.P. 2010. Inferências sobre a evolução petrológica do manto sudeste brasileiro a partir de microanálises de elementos traço em piroxênios e olivina de xenólitos de espinélio peridotitos. Resumo do $5^{\circ}$ Simpósio Brasileiro de Geologia do Diamante, Tibagi (PR), p.85.

Kretz R. 1983. Symbols for rock-forming minerals. American Mineralogist. 68: 277-279.

Le Roux V., Bodinier J.-L., Tommasi A., Alard O., Dautria J.-M., Vauchez A., Riches A.J.V. 2007. The Lherz spinel lherzolite: Refertilized rather tan pristine mantle. Earth and Planetary Science Letters. 259: 599-612.

Leonardos O.H. \& Araújo G.G. 1968. Preliminary study of peridotite nodules in basaltic rocks of the Cabugi Peak, Rio Grande do Norte, Brazil. Anais da academia brasileira de ciências, 40: 137-140.

Leonardos O.H. \& Meyer H.O. 1991. Geology of Western Minas Gerais.In:Field Guide book. $5^{\text {th }}$ International Kimberlite Conference, Araxá. CPRM Special Publication 91(3): 17-24.

Leonardos O.H., Carvalho J.B., Tallarico F.H.B., Gibson S.A., Thompson H.O.A., Dickin. 1993. O xenólito de granada lherzolito de Três Ranchos 4: uma rocha matriz do diamante na província magmática do Alto Paranaíba, Goiás. Anais do $1^{\circ}$ Simpósio Brasileiro de Geologia do Diamante, Cuiábá (MT), p. 3-16.

McDonough, W. F. and Sun, S.-s. (1995) The composition of the Earth. Chemical Geology, 120: 223-254. 
MacGregor I.D. 1974. The system MgO-Al2O3-SiO2: solubility of Al2O3 in enstatite for spinel and garnet peridotite compositions. American Mineralogist, 59:110-119.

Mercier J.C. and Nicolas A. 1975. Textures and fabrics of upper-mantle peridotites as illustrated by xenoliths from basalts. Journal of Petrology, 16: 454-487.

Meyer H.O.A. \& Svisero D.P. 1987. Mantle xenoliths in South America. In: Mantle Xenoliths, Nixon P.H. (ed.), p.85-91.

Meyer H.O.A. \& Svisero D.P. 1991. Limeira and Indaiá intrusions, Minas Gerais. 5th International Kimberlite Conference, CPRM Special Publication, Brasília, 3: 49-55.

Meyer H.O.A., Garwood B.L., Svisero D.P., Smith C.B. 1991. Alkaline ultrabasic intrusions in Western Minas Gerais, Brazil. In: Proceedings of the $5^{\text {th }}$ International Kimberlite Conference. v.1, p.140-155.

Mitchell R.H. 1986. Kimberlites: Mineralogy, Geochemistry and Petrology. Plenum Press, N.Y., $422 \mathrm{p}$.

Mitchell R.H. 1995. Kimberlites, orangeites, and related rocks. Plenum Press, N.Y., 409p.

Morimoto N., Fabries J., Ferguson A.K., Ginzburg I.V., Ross M., Seifert F.A., Zussman J., Aoki K., Gottardi G.1988. Nomenclature of pyroxenes. American Mineralogist, 73: 1123-1133.

Nannini F., Darcy D.P., Janasi V.A. 2010a. Petrografia de xenólitos mantélicos do kimberlito Indaiá, Monte Carmelo, Minas Gerais. Resumo do $5^{\circ}$ Simpósio Brasileiro de Geologia do Diamante, Tibagi (PR), p.84.

Nannini F., Janasi V.A., Darcy D.P. 2010b. Química mineral de xenólitos do kimberlito Indaiá, Monte Carmelo, Minas Gerais. Resumo do $5^{\circ}$ Simpósio Brasileiro de Geologia do Diamante, Tibagi (PR), p.89.

Nixon P.H., Knorring O. von, Rooke J.M. 1963. Kimberlites and associated inclusions of Basutoland: a mineralogical and geochemical study. American Mineralogist, 48:1090-1132.

Nixon P.H.1973. Lesotho Kimberlites. Lesotho National Development Corporation. Maseru, Lesotho, 350p.

Nixon P.H. 1987. Mantle Xenoliths. John Willey and Sons, New York, 844p.

Nixon P.H. 1995. A review of mantle xenoliths and their role in diamond exploration. Journal of Geodynamics, 20(4): 305-329.

Nixon P.H. \& Boyd, F.R. 1973a. Petrogenesis of the granular and sheared ultrabasic nodule suite in kimberlites. In: Nixon P.H.(ed) Lesotho Kimberlites. Maseru, Lesotho National Development Corporation, p.48-56. 
Nixon P.H. \& Boyd, F.R. 1973b. The discrete nodule association in kimberlites from northern Lesotho. In: Nixon P.H.(ed) Lesotho Kimberlites. Maseru, Lesotho National Development Corporation, p.67-75.

Nixon P.H., Boyd F.R., Boullier A.M. 1973. The evidence of Kimberlite and its inclusions on the Constitution of the Outer Part of the Earth. In: Nixon P.H.(ed) Lesotho Kimberlites. Maseru, Lesotho National Development Corporation, p.312-318.

Pearson D.G., Canil D., Shirey S.B. 2003. Mantle samples included in volcanic rocks: xenoliths and diamonds. In: Treatise on Geochemistry: The Mantle and Core, Elsevier Ltd., v.2, p.171275.

Pike J.E.N. \& Scharzman E.C. 1977. Classification of textures in ultramafic xenoliths. Journal of Geology, 85: 49-61.

Pollack H.N. \& Chapman, D.S. 1977. On the regional variation on heat flow, geotherms and lithospheric thickness. Tectonophysics, 38:279-296.

Richard, L. R. (1995). MinPet: Mineralogical and Petrological Data Processing System, Version 2.02. Québec: MinPet Geological Software.

Rudnick R.L., McDonough W.F., Orpin A. 1991. Northern Tanzanian peridotite xenoliths: a comparison with Kaapvaal peridotites and inferences on metasomatic interactions. In: Proceedings of the $5^{\text {th }}$ International Kimberlite Conference, Araxá, Brazil. v.1, p.336-353.

Seer H.J., Brod J.A., Fuck R.A., Pimentel M. M., Boaventura G.R., Dardenne M.A. 2001. Grupo Araxá em sua área tipo: um fragmento de crosta oceânica neoproterozóica na Faixa de dobramentos Brasília. Revista Brasileira de Geociências, 31(3): 385-396.

Sial, A.N. 1977. Petrology and mineral chemistry of peridotite nodules included in tertiary basaltic rocks of northeast Brazil. Geological Society American Bulletin, 88:1173-1176.

Silva, S. 2008. Petrografia e química mineral das intrusões Indaiá I e Indaiá II, oeste do estado de Minas Gerais. Dissertação de Mestrado do Instituto de Geociências, Universidade de São Paulo, 113p.

Streckeisen A. 1976. To each plutonic rock its proper name. Earth-Science Reviews, 12: 1-33.

Sun Shen-su \& McDonough W. F. 1989. Chemical and Isotopic Systematics of oceanic basalts: implications for Mantle Composition and Processes. In A.D. Saunders and M.J. Norry (eds.) Magmatism in the Ocean Basins, Special Publication Volume of Geologic Society of London, 42: 313-345.

Svisero D.P. \& Haralyi N.L.E. 1984. O Kimberlito Indaiá, Monte Carmelo, MG. Anais $33^{\circ}$ Congresso Brasileiro de Geologia, vol.10, p.5014-5026. 
Svisero D.P., Meyer H.O.A and Tsaiet H. 1977. Kimberlite minerals from Vargem and Redondão diatremes, Brazil. Revista Brasileira de Geociências, 7: 1-13.

Svisero D.P., Nannini F., Vlach S.R.F., Mansueto, M. 2010. Composição e origem de minerais resistatos da região de Coromandel e áreas adjacentes, Minas Gerais. Resumo do $5^{\circ}$ Simpósio Brasileiro de Geologia do Diamante, Tibagi (PR), p.63.

Svisero D.P. \& Ulbrich M.N.C. 1997. Aspectos geológicos e petrográficos comparados de algumas intrusões kimberlíticas da região de Monte Carmelo, Minas Gerais. Boletim de Resumos e Roteiro de Excursão do $2^{\circ}$ Simpósio Brasileiro de Geologia do Diamante, Cuiabá (MT), p. 41-43.

Tallarico F.H.B. \& Leonardos O.H. 1995. Glimeritic and peridotitic xenoliths from the Mata do Lenço micaceous kimberlite - Alto Paranaíba Igneous Province, Brazil: evidences of metasomatic processes in local mantle sources. In: Extended abstracts, $6^{\text {th }}$ International Kimberlite Conference, Russia, v.4, p.600-602.

Thomaz L.V. 2009. Estudo petrográfico e química mineral da intrusão kimberlítica Régis, no oeste de Minas Gerais. Dissertação de Mestrado, Instituto de Geociências, Universidade de São Paulo, 143p.

Wagner, P.A., 1914. The diamond fields of southern Africa. Transvaal Leader, Johannesburg, $347 \mathrm{p}$.

Wells P.R.A. 1977. Pyroxene thermometry in simple and complex systems. Contributions to Mineralogy and Petrology 62: 129-139.

Williams, A.F.1932. The genesis of diamond. Ernest Benn, London, 536p.

Wyatt B.A., Baumgartner M., Anckar E., Grutter H. 2004. Compositional classification of "kimberlitic" and "non-kimberlitic" ilmenite Lithos 77 ed. Elsevier p.819-840.

Zhang H., Nakamura E., Kobayashi K., Ying J., Tang Y. 2010. Recycled crustal melt into lithospheric mantle: implication from cumulative composite and pyroxenite xenoliths. International Journal of Earth Sciences, 99: 1167-1186.

Zheng J., Griffin W.L., O'Reilly S.Y., Zhang M., Pearson N. 2006. Zircons in mantle xenoliths record the Triassic Yangtze-North China continental collision. Earth and Planetary Science Letters, 247(1-2): 130-142. 